\author{
UNIVERSIDADE DE SÃO PAULO \\ FACULDADE DE FILOSOFIA, LETRAS E CIÊNCIAS HUMANAS \\ DEPARTAMENTO DE HISTÓRIA \\ PROGRAMA DE PÓS GRADUAÇÃO EM HISTÓRIA SOCIAL
}

ANDRÉ LUIZ RODRIGUES CARREIRA

A RUA, A LUTA E O LÚDICO: URBANIZAÇÃO, TRABALHO E FUTEBOL NA CIDADE DE SANTOS (1892 - 1920) 


\author{
UNIVERSIDADE DE SÃO PAULO \\ FACULDADE DE FILOSOFIA, LETRAS E CIÊNCIAS HUMANAS \\ DEPARTAMENTO DE HISTÓRIA \\ PROGRAMA DE PÓS GRADUAÇÃO EM HISTÓRIA SOCIAL
}

ANDRÉ LUIZ RODRIGUES CARREIRA

\title{
A RUA, A LUTA E O LÚDICO: URBANIZAÇÃO, TRABALHO E FUTEBOL NA CIDADE DE SANTOS (1892 - 1920)
}

Versão Corrigida

\begin{abstract}
Tese apresentada ao Programa de Pós Graduação em História do Departamento de História da Faculdade de Filosofia, Letras e Ciências Humanas da Universidade de São Paulo, para o título de Doutor em História Social
\end{abstract}

Orientador: Flavio de Campos

São Paulo 
Autorizo a reprodução e divulgação total ou parcial deste trabalho, por qualquer meio convencional ou eletrônico, para fins de estudo e pesquisa, desde que citada a fonte.

\section{Versão Corrigida}

\section{Catalogação na Publicação}

Serviço de Biblioteca e Documentação Faculdade de Filosofia, Letras e Ciências Humanas Universidade de São Paulo

C314r Carreira, André Luiz Rodrigues.

A rua, a luta e o lúdico: urbanização, trabalho e futebol na cidade de Santos

(1892 - 1920) / André Luiz Rodrigues Carreira; orientador Flavio Campos. - São Paulo, 2019.

$169 \mathrm{f}$.

Tese (Doutorado) - Faculdade de Filosofia, Letras e Ciências Humanas da Universidade de São Paulo. Departamento de História. Área de concentração: História Social.

1. Futebol. 2. Urbanização. 3. Trabalho. I. Campos, Flavio, orient. II. Título. 


\section{ENTREGA DO EXEMPLAR CORRIGIDO DA DISSERTAÇÃO/TESE \\ Termo de Ciência e Concordância do (a) orientador (a)}

Nome do (a) aluno (a): André Luiz Rodrigues Carreira

Data da defesa: ___11_/_12_/_2019__

Nome do Prof. (a) orientador (a): Flavio de Campos

Nos termos da legislação vigente, declaro ESTAR CIENTE do conteúdo deste EXEMPLAR CORRIGIDO elaborado em atenção às sugestões dos membros da comissão Julgadora na sessão de defesa do trabalho, manifestando-me plenamente favorável ao seu encaminhamento e publicação no Portal Digital de Teses da USP.

São Paulo,__20____01___2020_

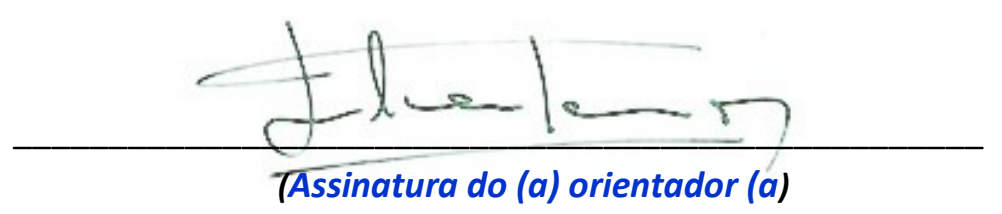




\section{AGRADECIMENTOS}

A realização desse trabalho não teria sido possível sem a participação e colaboração de um número muito grande de pessoas.

Agradeço inicialmente ao meu orientador Flavio de Campos e aos membros de minhas bancas de qualificação e defesa, Maria Lúcia Caira Gitahy, Fernando Atique e José Geraldo Vinci de Moraes, pela leitura atenta, pelos elogios e críticas e pelos caminhos sugeridos.

Agradeço imensamente o trabalho realizado pelos funcionários de diversas instituições como Fundação Arquivo e Memória de Santos, Arquivo Público do Estado de São Paulo, Arquivo Edgard Leuenroth, Museu De Vaney, Jornal A Tribuna, Centro de Memória do Santos Futebol Clube, Associação Atlética Portuguesa, Jabaquara Atlético Clube, Clube dos Ingleses, Sociedade Humanitária dos Empregados do Comércio, Hemeroteca Municipal de Santos, Museu do Porto e Instituto Moreira Salles.

Ao meu pai, Augusto Carreira, falecido durante a elaboração desse trabalho, pelo despertar de minha paixão pela bola, pelos gramados, pela arquibancada e pelos alambrados.

À minha mãe, pelo amor e apoio de sempre e, acima de tudo, por ter criado condições para que hoje eu pudesse estar aqui.

Cauana Donat, pelo tempo presente e de longa duração. Pelo amor, combustível diário. Sem você ao meu lado, nada disso seria possível.

Pedro, meu filho, um bebê no início e um menino no final desse percurso. Com você percebi que as utopias são possíveis. Vejo no seu olhar a leveza com a qual gosto de sonhar. Que sejamos capazes de construir para você um mundo mais inclusivo e fraterno do que esse que se apresenta e se avizinha. Que os seus passos, agora já firmes, te levem pelos caminhos da luta por uma sociedade mais justa e menos desigual. 


\section{RESUMO}

O presente trabalho tem por objetivo central analisar o processo de transformação urbana ocorrido na cidade de Santos entre o final do século XIX e o início do século XX pelo mundo do trabalho e por um dos elementos culturais fundamentais da classe trabalhadora, o futebol. Pretendo ainda analisar os conflitos inerentes à formação de tais iniciativas voltadas predominantemente para o recreio, em parte resultantes do choque entre as propostas culturais formuladas para os trabalhadores por anarquistas e militantes sindicais e outras formas de lazer de classe rapidamente popularizadas. Por fim, a pesquisa procura compreender o espaço ocupado pelas agremiações dedicadas ao futebol nas tensões e contradições entre capital e trabalho e entre as diferentes nacionalidades (mitigando ou reforçando oposições e rivalidades) representadas na população de Santos do período citado.

Palavras-chave: Cidade; Futebol; Trabalho.

\section{ABSTRACT}

This doctoral research aims to analyze the process of urban transformation that occurred in the city of Santos between the end of the nineteenth century and the beginning of the twentieth century by the world of work and one of the fundamental cultural elements of the working class, football. I also want to analyze the conflicts inherent in the formation of such initiatives that are predominantly for recreation, partly as a result of the clash between the cultural proposals formulated for the workers by anarchists and trade union militants and other forms of class leisure that are rapidly popularized. Finally, the research tries to understand the space occupied by the associations dedicated to football in the tensions and contradictions between capital and labor and among the different nationalities (mitigating or reinforcing oppositions and rivalries) represented in the population of Santos in the mentioned period.

Keywords: City; Football; Labor. 
SUMÁRIO

Introdução

1 - Capítulo 1: Formação e transformação do espaço urbano santista: planos, práticas, limites e contradições 11

1.1. Uma cidade, múltiplas dimensões 13

1.2. Ferrovia, porto e a formação do espaço urbano santista 13

1.3. O "inimigo traiçoeiro": epidemias e as propostas de intervenção 22

1.4. Planos urbanísticos e as disputas por um projeto de cidade 24

1.5. A cidade em transformação: ampliação dos limites físicos e redefinição dos espaços urbanos 29

2 - Capítulo 2: Da civilização idealizada ao trabalhador indesejado: demografia, nacionalidade e formação da classe trabalhadora santista 60

2.1. O Censo de 1913 e a população santista nos primeiros anos do século XX 63

2.2. Imigração européia e o mundo do trabalho: a vida cotidiana da população pobre na cidade de Santos 65

2.3. Os trabalhadores da cidade de Santos: organização, luta e resistência 69

3 - Capítulo 3: A bola rola nos caminhos da cidade: o futebol santista no alvorecer do século XX 91

3.1. As elites e os sports: práticas e espaços de distinção 93

3.2. O futebol na cidade de Santos: gênese e intersecções 98

3.3. Santos Football Club: rivalidades e a construção da hegemonia do "time da cidade" 102

3.4. Os tentáculos do grande capital e o mundo do trabalho: da luta ao lúdico 108 
3.5. A classe trabalhadora entra em campo

3.6. Hespanha e Portuguesa: canteiros, jornaleros e os "times de colônia"

3.7. A bola rola nos caminhos da cidade: capital, trabalho e futebol na Santos dos anos 1910

4 - Considerações Finais 150

5 - Referências 152

6 - Lista de Imagens 159 
"A rua nasce, como o homem, do soluço, do espasmo. Há suor humano na argamassa do seu calçamento. Cada casa que se ergue é feita do esforço exaustivo de muitos seres, e haveis de ter visto pedreiros e canteiros, ao erguer as pedras para as frontarias, cantarem, cobertos de suor, uma melopéia tão triste que pelo ar parece um arquejante soluço. A rua sente nos nervos essa miséria da criação, e por isso é a mais igualitária, a mais socialista, a mais niveladora das obras humanas."

(João do Rio, A Alma Encantadora das Ruas, 1905)

"Que se cruzem notebook e bola, tambor e livro, para que os corpos leiam e bailem na aventura maior do caminho que descortina o ser naquele espaço que chega a ser maior que o mundo: a rua."

(Luiz Antonio Simas, O Corpo Encantado das Ruas, 2019)

"O fenômeno esportivo em geral, futebolístico em particular, é uma manifestação plenamente urbana, que palpita de um modo ou de outro por todos os desvãos da cidade e preenche o tempo ampliado das horas de lazer. A cidade não assiste ao esporte como um episódio isolado e externo: ela lhe dá vida, corpo e voz - ela não o vê de fora, ela se vê nele."

(Nicolau Sevcenko, Orfeu Extático na Metrópole, 1992) 


\section{INTRODUÇÃO}

Parece desnecessário, por sua notória onipresença, reafirmar que os esportes ocupam um lugar de incontestável destaque no mundo contemporâneo. Em suas atuais estruturas, a vida urbana abriga inúmeros espaços destinados à prática esportiva, seja ela de caráter profissional, apresentada como espetáculo, seja ela uma atividade de caráter mais informal, disseminada pelo tecido urbano em escolas, praças, ruas e praias. Para atingir esse patamar de inserção na dinâmica espacial de uma cidade, os esportes cumpriram historicamente um longo e complexo percurso, do qual analisaremos aqui uma etapa que julgamos crucial.

Trabalhamos com o pressuposto básico de que o momento decisivo de construção desse amplo cenário guarda importantes conexões com o advento da modernidade urbana. Nesse sentido, este trabalho se estrutura a partir de um objetivo central: analisar o processo de transformação urbana ocorrido na cidade de Santos entre o final do século XIX e o início do século XX pelo mundo do trabalho e por um dos elementos culturais fundamentais da classe trabalhadora, o futebol.

O espaço urbano, no seu processo de transformação, é simultaneamente registro e agente histórico. Nesse sentido, deve-se destacar a noção de territorialidade, identificando o espaço enquanto experiência individual e coletiva, onde a rua, a praça, a praia, o bairro, os percursos estão plenos de lembranças, vivências e memórias. Espaços que, além de sua existência material, são também codificados num sistema de representação que deve ser focalizado pelo pesquisador, em um intenso trabalho de investigação sobre as significações dos processos urbanos.

Estudar a cidade implica estabelecer conexões de tipo variado com a própria experiência de viver em cidades. Conexões objetivas de moradia e trabalho, laços afetivos tecendo espaços nos quais as lembranças compõem um acervo especial, nós intrincados que relacionam expectativas e imagens, idealizadas em grande parte e resistentes à passagem do tempo (BRESCIANI, 2018). O interesse intelectual pelo estudo das cidades - e por Santos, em especial - procede com certeza de questões colocadas no presente, ainda quando nos fazem retroceder para um momento no qual consideramos poder captar um elo significativo que elucide as pouco acolhedoras condições de vida nos ambientes urbanos contemporâneos. 
O período abarcado pela pesquisa - começo da República - é marcado por duas ideias que norteiam a atuação do poder público em relação à cidade: civilizar, interferindo no espaço urbano e nos hábitos cotidianos, e higienizar, através do saneamento urbano.

$\mathrm{O}$ ato de civilizar era visto como tentativa de impor à cidade padrões urbanos e comportamentais ditos modernos e similares aos das capitais europeias. Foi essa, em larga medida, a perspectiva da reforma urbana conduzida no período, especialmente através dos projetos desenvolvidos e capitaneados por Saturnino de Brito. A reorganização do espaço urbano teve como objetivo consolidar a inserção do Brasil no modelo capitalista internacional - no caso de Santos, através do escoamento da produção da grande riqueza nacional, o café -, facilitar a circulação de mercadorias e construir espaços simbólicos que afirmassem os valores de uma elite cosmopolita.

Havia, entretanto, um obstáculo a ser removido para a concretização da Belle Époque tropical: os pobres - imigrantes de origem ibérica, em sua maioria - que habitavam aos milhares as ruas centrais da cidade e moravam majoritariamente em habitações coletivas como os cortiços. Do "bota-abaixo" às imposições do Código de Posturas e das comissões de saneamento, a normatização, a segregação e a exclusão da numerosa e empobrecida população trabalhadora ditava o ritmo de crescimento e transformação citadina.

A reforma resolvia uma série de problemas e contradições da cidade e gerava uma indagação: o que fazer com os homens e mulheres que os governos definiam como "elementos das classes perigosas", que habitavam as regiões centrais e que eram obstáculos à concretização da desejada e idealizada modernidade?

A relação das elites e do poder público com os pobres era paradoxal. Os "perigosos" - e aqui é curioso notar a rápida desconstrução de certa idéia de civilidade associada aos imigrantes de origem europeia que logo se transformariam em "agitadores" pelo pertencimento em larga escala à combativa classe operária local - maculavam, do ponto de vista da ocupação e reordenação do espaço urbano, o sonho da cidade cosmopolita. Ao mesmo tempo, eram os trabalhadores urbanos que sustentavam - ao realizar o trabalho braçal que as elites não cogitavam fazer - a viabilidade desse mesmo sonho: operários, empregadas domésticas, estivadores, ensacadores, canteiros, marceneiros, policiais, pedreiros, carpinteiros, pintores, funileiros, carregadores de café, tecelões, jornaleiros, mecânicos, coveiros, motoristas, etc. 
Nesse espaço em formação e transformação, de tensão e construção de novas sociabilidades, uma rica atividade esportiva, caracterizada pela introdução e multiplicação de novas modalidades e pela proliferação de associações a agremiações criadas para esse fim se consolida nas primeiras décadas de vida republicana. Procuramos inserir tal movimento de disseminação - do futebol, principalmente - no contexto da dinâmica sócio-espacial urbana de então, sugerindo hipóteses que a articulem ao movimento geral da sociedade e substancialmente à espacialidade da cidade pretensamente moderna que se configurava.

Pensando o surgimento e disseminação do futebol na cidade de Santos na articulação entre história do esporte, história urbana e história do trabalho, a investigação se subdivide em três capítulos.

No primeiro capítulo, a ênfase recai sobre o processo de formação e transformação urbana de Santos na transição do século XIX para o século XX. Embora afetada duramente pelas epidemias de fins dos oitocentos, a cidade rapidamente se consolidava como porta de saída da produção de café e como porta de entrada para os milhares de imigrantes de origem europeia. $\mathrm{O}$ incremento das atividades portuárias e as reformas urbanas de caráter sanitarista modificariam drasticamente o aspecto físico da cidade. Os planos e ações de intervenção se sucederiam, criando novos espaços e redes de sociabilidade.

Outra questão colocada nesse primeiro momento é onde localizar o desacerto e a distância que se interpuseram entre as intenções projetuais dos urbanistas - principalmente Saturnino de Brito - e das autoridades municipais e estaduais e a cidade tal como se apresentava.

No segundo capítulo, o eixo de discussão reside na análise das estratégias de luta e sobrevivência da população pobre e trabalhadora de Santos no período. Discutiremos a composição demográfica santista através do minucioso censo realizado pela municipalidade em 1913 e a expressiva influência europeia na população local. Por fim, analisaremos as formas de organização e resistência engendradas pela classe trabalhadora santista entre o final do XIX e as primeiras décadas do século XX.

Na cidade que se configurava, os sports seriam elementos indissociáveis da ideia de modernidade que se pretendia instaurar e da marca de progresso que se pretendia imprimir. A cidade capitalista, como apontado por Mascarenhas (2014), é um espaço de confrontos. Os 
trabalhadores, ao longo da história, formataram diversas estratégias de organização e embates diante do processo de formação da sociedade burguesa. Tais estratégias incluem a apropriação cotidiana dos espaços para satisfazer necessidades diversas, da sobrevivência material imediata ao lazer e à sociabilidade.

Foi assim que o futebol, prática social inicialmente formatada no seio das elites e difundida rapidamente como indústria do espetáculo (portanto, inserida no circuito de acumulação), conquistou as periferias urbanas e os segmentos mais empobrecidos da população.

No terceiro e último capítulo, analisaremos a rápida apropriação de práticas esportivas o futebol, especialmente -, inicialmente elitizadas e concebidas como elementos de distinção de classe, pela população pobre e trabalhadora da cidade. Procuraremos demonstrar que o futebol não foi conseqüência e sim parte constituinte do processo de transformação urbana santista nos primeiros anos do século passado.

Importante ressaltar, em relação à temática do capítulo derradeiro, as dificuldades encontradas no acesso à documentação de clubes e agremiações esportivas. As referências, mesmo em clubes ainda em atividade e exceção feita ao Santos Futebol Clube (através do seu Centro de Memória), eram geralmente esparsas e pouco organizadas. Foi preciso recorrer a diversos outros centros de documentação e fundos documentais. Estendo aqui o meu agradecimento aos profissionais da Fundação Arquivo e Memória de Santos, Arquivo Público do Estado de São Paulo, Arquivo Edgard Leuenroth, Museu De Vaney, Jornal A Tribuna, Sociedade Humanitária dos Empregados do Comércio, Hemeroteca Municipal de Santos, Museu do Porto e Instituto Moreira Salles.

Esse foi, em síntese, o cenário sobre o qual nos debruçamos quando da realização da pesquisa sobre a cidade de Santos. Uma cidade que se vê abruptamente solapada pelo incessante movimento de pessoas e de interesses que se aglutinavam. Uma cidade que velozmente se metamorfoseava no cais de pedra, nos canteiros de obras, nos cortiços, nos morros, nos canais, nas largas avenidas, nas greves, nas lutas, nas areias, nos gramados, enfim, na bola que rolava e que nunca mais deixou de rolar. 
CAPÍTULO 1: Formação e transformação do espaço urbano santista: planos, práticas, limites e contradições 
"Eram duas cidades diferentes: a de cá, escura, poeirenta, cheia de movimento e barulho, suada de trabalho; a de lá, clara, limpa, alegre, refrescada pelo sopro do mar, com gente ociosa no hall dos hotéis, bebendo, tomando banho, espiando as mulheres."

(Ranulfo Prata, Navios Iluminados, 1937) 


\subsection{Uma cidade, múltiplas dimensões}

O trabalho em questão está circunscrito cronologicamente entre o final do século XIX e, principalmente, as primeiras décadas do século XX. A pesquisa procura discutir o surgimento e a disseminação da prática de futebol na cidade de Santos nas décadas de 1900 e 1910 como elementos constituintes do processo de formação e transformação da cidade.

O recorte temporal - entre os anos de 1892 e 1920 - justifica-se por uma reflexão que permeou todo o desenvolvimento desse trabalho: a dicotomia entre a cidade "moderna" que se idealizava e o seu avesso, caracterizado pela existência de uma população majoritariamente pobre e excluída das benesses das transformações citadinas, pela presença de uma combativa classe trabalhadora e pela constante repressão às manifestações políticas e culturais de grande parte de seus habitantes $O$ ano de 1892 marca a inauguração dos primeiros 260 metros de cais de pedra do porto de Santos, marco fundamental no processo de transformação urbana que se desenhava e da formação da cidade moderna que se pretendia. 0 ano de 1920 , ponto culminante desse trabalho, é o ano da grande greve dos canteiros, marco do processo de reorganização da classe trabalhadora santista, e da consolidação do futebol como manifestação cultural essencialmente popular.

A cidade de Santos do início do período republicano é um dos casos paradigmáticos das intensas transformações pelas quais passava um país independente que procurava inserir-se nos marcos internacionais do desenvolvimento capitalista tanto do ponto de vista das relações econômicas quanto pela incorporação de doutrinas, valores e modos de vida. As profundas e aceleradas mudanças ocorridas no espaço urbano santista na virada do século eram, entretanto, um desdobramento até certo ponto natural de dois elementos fundamentais para a compreensão desse período: o incremento das atividades portuárias e a construção da ferrovia ligando a cidade de Santos ao planalto.

Os limites físicos da cidade - fundada em meados do século XVI - só foram alterados de forma significativa nas últimas décadas do século XIX com as novas características que ela foi gradativamente assumindo e com o consequente crescimento populacional. Foi então que se incorporaram novas áreas em direção às praias e também para o leste. A expansão em direção ao planalto paulista cessou no momento de implantação da ferrovia (LANNA, 1996).

\subsection{Ferrovia, porto e a formação do espaço urbano santista}


A década de 1850 significa verdadeiro ponto de inflexão para o crescimento da cidade (GONÇALVES, 1995). É nessa década que as exportações de café suplantaram as de açúcar e, já em 1854, Santos se torna responsável por quase $80 \%$ da movimentação exportadora brasileira do produto (ANDRADE, 1989). A construção da Estrada de Ferro Santos-Jundiaí, inaugurada em 1867, significou impulso definitivo ao fluxo de mercadorias produzidas no planalto, especialmente o café, rumo ao porto de Santos. Inicialmente concessão feita pelo governo central a um consórcio composto por Barão de Mauá, Marquês de Monte Alegre e J.A. Pimenta Bueno na década de 1850, a ferrovia, no momento de sua conclusão e inauguração, já havia sido transferida para a companhia inglesa São Paulo Railway, responsável direta pela administração da ferrovia até 1946. A empresa possuía todos os privilégios habituais concedidos às ferrovias no Brasil imperial: isenção de impostos para importação de materiais e garantia de juros mais baixos (SAES, 1979). Seus objetivos eram claros: café que descia; produtos e trabalhadores que subiam.

A expressiva presença britânica na cidade de Santos a partir da segunda metade do século XIX - presença que se manifestava através não apenas de capitais investidos, mas de funcionários de empresas instaladas - teria relação direta com o surgimento de clubes dedicados a práticas esportivas e a algumas das primeiras iniciativas ligadas à gênese do futebol santista. Trataremos disso mais adiante.

O crescimento do porto de Santos, interligado ao sistema ferroviário, nas últimas décadas do século XIX se insere em um contexto mais amplo de mudanças significativas no mundo e, em especial, na província de São Paulo. Segundo Eric Hobsbawm (2007, p. 78-84), a economia mundial apresentou características específicas nesse período, entre elas, o crescimento de produtos primários em diversos países, inclusive na América Latina; maior pluralismo econômico, apesar da dependência em relação aos serviços financeiros e comerciais britânicos; um novo ciclo de desenvolvimento tecnológico acelerado, atualizando as inovações da primeira Revolução Industrial através do aperfeiçoamento das tecnologias do vapor e do ferro; mudanças quantitativas e qualitativas no mercado de bens de consumo com a formação de mercados de massas não somente para as necessidades básicas, ligadas à alimentação e vestuário, mas se estendendo a outros e mais diversificados bens de consumo; expansão do setor terciário, com proliferação de lojas, escritórios e outros serviços.

Nas cidades latino-americanas, a formação de mercados internos mais expressivos vai se configurando nesse mesmo período. Sobre essa questão, o estudo de Arnold Bauer (2001) nos traz informações relevantes. Segundo ele, da metade do século XIX em diante, uma camada de consumidores crescente - apesar da desigualdade econômica e pobreza - situada entre os 
ricos proprietários de terras com residência na cidade e a maior parte da população fixada nas áreas rurais, preocupou-se em se distinguir da massa residente nas zonas não urbanas através da adoção de novos hábitos de consumo e comportamento. As cidades onde se encontravam esses novos consumidores foram, em um primeiro momento, as portuárias e aquelas interligadas ao mundo exterior por meio de linhas férreas ou fluviais (BAUER, 2001, p. 32). A renda gerada nos últimos trinta anos dos oitocentos pela grande procura por bens primários, principalmente café no caso brasileiro, tornou possível a importação, por parte dos países exportadores de matérias primas e produtos agrícolas, de bens manufaturados destinados a suprir necessidades cotidianas tanto quanto de inseri-los nos padrões de comportamento europeu e norte-americano ditos "civilizados" e "modernos". Pode-se dizer que esse foi o caso de Santos e São Paulo, cidades que passaram por intensas transformações econômicas e sociais com a expansão da produção e exportação de café na segunda metade do século XIX.

A íntima relação entre planície e planalto já havia sido destacada por Caio Prado Jr. (1971) como base do organismo econômico da província em tempos anteriores à expansão do café. Já com a expansão da economia cafeeira essa antiga relação passou a contar com novos suportes sustentados pelos investimentos em infra-estrutura portuária e pela inauguração da já citada ferrovia São Paulo Railway. Dessa forma, a ligação comercial entre Santos e São Paulo foi importante tanto para a manutenção do comércio de produtos ligados ao consumo interno como daqueles que se destinavam à exportação. Segundo Paul Singer:

\footnotetext{
“A partir de 1868 o sistema São Paulo-Santos se insere de forma cada vez mais sólida no grande comércio cafeeiro e, a partir da última década do século passado, arrebata ao Rio de Janeiro sua posição hegemônica, tornando-se o grande eixo de comercialização do produto-rei da exportação brasileira" (SINGER, 1968, p. 26)
}

O impacto da expansão da economia cafeeira sobre o desenvolvimento paulista teve seus desdobramentos na vida urbana das cidades diretamente envolvidas. Como aconteceu em São Paulo no mesmo período, em Santos os implementos de infra-estrutura urbana, como luz a gás e elétrica, pavimentação de ruas, circulação de bondes, saneamento e o conjunto de bens de consumo em circulação foram fatores de distinção cada vez maior entre a cultura material do campo e da cidade, somando-se a isso novas formas de sociabilidade e lazer (e as próprias idéias de sociabilidade e lazer) como encontros em locais públicos, a ida ao teatro e/ou a um café e a gênese dos espetáculos esportivos. 
$\mathrm{Na}$ busca por compreender as transformações urbanas da cidade, descortinou-se um conjunto de intensas mudanças vivenciadas pela população local nas três últimas décadas do século XIX.

Sabe-se que a configuração urbana de Santos até meados dos 1800 era a de um sítio plano com sua população desenvolvendo-se junto ao seu marco inicial denominado Outeiro de Santa Catarina, às redondezas do largo em frente à antiga Igreja da Misericórdia (depois Igreja Matriz) e próximo ao convento e igreja dos Jesuítas. Era neste núcleo que as funções militares e administrativas se realizavam devido à existência de quartéis, casa do trem, da Casa de Câmara e Cadeia (ver imagem 1, p. 46) e da Alfândega. A finalização da construção do convento franciscano do Valongo, do lado oposto, representou, durante séculos, o limite de expansão territorial da parte habitada da vila. Nesse segundo núcleo de povoamento, predominavam as funções comerciais, já que a região do Valongo estava mais próxima dos que chegavam de São Paulo. O caminho que ligava os dois núcleos urbanos deu origem, ainda no século XVII, à rua principal da vila, sendo seu trecho mais importante a chamada rua Direita (atual rua $X V$ de Novembro), que seguia paralela ao porto. $O$ trecho mais afastado do mar que segue até o convento do Valongo deu origem à rua Santo Antônio (atual rua do Comércio).

A partir da segunda metade do século XIX, houve um impulso no interesse pela ocupação da região do Valongo. Isso ocorreu, particularmente, devido à perspectiva gerada pela construção da estrada de ferro São Paulo Railway durante a década de 1860 (ANDRADE, 1989, p. 98). Logo, se os negociantes que se estabeleceram nessa área pretendiam ficar mais próximos do ponto de ligação com o planalto, a instalação da ferrovia representou um investimento ainda mais significativo para que as ruas adjacentes ao porto fossem ocupadas por um número ainda maior de casas comerciais (MARCONDES, 2010, p. 22). Ana Lucia Duarte Lanna (1996, p. 55) aponta que, ao redor da ferrovia:

\footnotetext{
“apareciam novos espaços de convivência. Os quiosques instalados na estação rapidamente transformaram-se em local de encontro da população. Alterou significativamente o tecido urbano e, ao associar-se ao porto, definiu essa área da cidade como essencialmente comercial."
}

Assim, a ocupação da região do Valongo foi impulsionada pela expansão do comércio, acompanhada tanto por investimentos na infra-estrutura regional, representada pela nova estrada de ferro, como local, pelos incrementos urbanos representados pelas mudanças nos sistemas de abastecimento de água, iluminação, transportes e na posterior construção do cais. 
$\mathrm{Na}$ cidade, de uma forma geral, a intensificação do comércio exterior, o adensamento populacional e a proliferação de doenças foram os argumentos utilizados para uma série de transformações promovidas nos serviços públicos oferecidos. Diversos requerimentos, já na década de 1870, encaminhados à Câmara Municipal, seguiam nesse sentido, compondo-se tanto de propostas para a realização de obras quanto de queixas de munícipes. Em parecer de 10 de abril de 1875, a Câmara Municipal de Santos aponta a criação da companhia anônima "Melhoramentos da Cidade de Santos". A empresa teria por objetivo o "estabelecimento de água, gás e trilhos urbanos para cargas e passageiros." A sociedade formada no Rio de Janeiro por John Frederic Russell, Eduardo Everett Benest e por Thomaz Cochrane, empresários ligados ao fornecimento desses serviços na capital, obteve concessão do governo imperial para implantá-los também na cidade de Santos a partir de 1870. A empresa foi pioneira no fornecimento de água encanada para distribuição domiciliar e em chafarizes para uso público e promoveu o serviço de iluminação a gás de hulha, substituindo os antigos lampiões que funcionavam à base de óleo de peixe. O privilégio do transporte de passageiros e cargas passou a ser exercido através de um consórcio composto pela empresa Melhoramentos e Domingos Moutinho, a quem o serviço havia sido concedido anteriormente, por um prazo de 50 anos (MARQUES JR., 2006, p. 59). Anos mais tarde, em 1881, por decreto do governo imperial, os mesmos serviços passaram a ser prestados por um grupo de ingleses que fundaram a The City of Santos Improvements \& Co Ltda, incorporando ao seu patrimônio a antiga Companhia Melhoramentos. O desenvolvimento urbano, mesmo que concentrado na área comercial da cidade, era festejado pela Câmara e apresentado a figuras ilustres que vinham em visita à cidade, como aconteceu na passagem de D. Pedro II por Santos, em agosto de 1875:

$\mathrm{Na}$ ocasião de irem para a Matriz, os augustos viajantes (Imperador e Imperatriz) apreciaram as brilhantes iluminações públicas e particulares, sobressaindo entre estas a da Praça do Comércio, entre aquelas a abóboda de luz formada por arcos iluminados a gás, e que se estendia do Arsenal à Estação. Fora marcada pelo Imperador para esse dia a excursão à vila de São Vicente pela nova linha de bondes. (...) (Ata da Câmara Municipal de Santos, 29 de agosto de 1875)

Foram grupos estrangeiros e nacionais com sede em cidades como Londres e o Rio de Janeiro que tiveram condições de investir nos serviços de grande porte em Santos. Santos, 
como cidade que crescia vertiginosamente (GONÇALVES, 1995), era atraente para esses empresários que administravam negócios pioneiros na Corte. De forma simultânea às questões maiores do desenvolvimento urbano, os habitantes também buscavam soluções próprias para os problemas cotidianos que os afligiam. Do ponto de vista dos homens ligados ao comércio, a leitura das atas da Câmara Municipal indica uma intensa participação sempre que os problemas urbanos relacionados ao transporte, serviços de água, luz, entre outros, se tornavam empecilhos às suas atividades. Por isso, a existência de diversos requerimentos pedindo providências à administração pública ou exigindo permissões para que as próprias empresas privadas realizassem determinados serviços públicos.

Além das questões ligadas ao saneamento (ou melhor, ausência de saneamento) e às epidemias - discutiremos esse assunto mais adiante - surge nas atas o problema da circulação urbana. Entre as novas necessidades impostas pelo crescimento do comércio estava o trânsito de produtos e pessoas pelas ruas da cidade (ver imagem 2, p. 46). A cidade pretensamente moderna que se pensava em fins do século XIX precisava de novos espaços. No caso de Santos, as mudanças se tornaram mais evidentes no centro comercial que crescia junto ao porto e à ferrovia São Paulo Railway. A condução de cargas e passageiros era feita em grande parte por carroças até a inauguração dos bondes pela Companhia de Melhoramentos, como citado anteriormente. Em pouco tempo, a coexistência entre dois tipos distintos de transporte - o bonde associado ao "moderno" e as carroças a uma certa idéia de "atraso" - e as primeiras manifestações de descontentamento por parte da empresa encarregada da nova infraestrutura urbana não demorariam a chegar à Câmara Municipal. Em ofício de 31 de outubro de 1872, utilizando como base o Código de Posturas Municipais, a Companhia Melhoramentos pediu providências sobre como era feito o transporte por carroças pela cidade. Segundo a empresa, os carroceiros faziam questão de "interromper a rapidez indispensável na marcha dos bondes, conservando as carroças de forma intencional por muito tempo sobre os trilhos." Poucos dias depois, em ofício do início de novembro de 1872, a Câmara, em favor da Companhia Melhoramentos, pediu ao delegado de polícia uma "intervenção para a execução do Código a fim de que os embaraços chegassem ao fim."

Os ofícios constantemente protocolados junto à administração municipal oferecem singular oportunidade para a compreensão da penetração dos interesses empresariais na máquina pública santista. As casas comerciais, por exemplo, buscavam alternativas para que a circulação nas ruas em que atuavam funcionasse de forma mais eficiente. Entre as soluções para o acesso a determinados pontos da cidade, um requerimento da casa importadora Theodor Wille \& Company expôs a necessidade de abertura de uma rua que fosse em direção 
ao porto, oferecendo terrenos de sua propriedade para que tal obra fosse efetuada (MARCONDES, 2010, p. 29). Algumas dessas firmas juntavam-se para pedir à administração municipal a ligação das linhas de bondes, instaladas no centro da cidade, às novas pontes de embarque construídas no porto ou nos armazéns que estavam sob seus serviços nas ruas próximas, como é o caso da F.S. Hampshire \& Company, que requisitou em ofício datado de 5 de abril de 1882, permissão junto à Câmara para que a empresa City colocasse seus trilhos em comunicação com as pontes da rua Xavier da Silveira, nas proximidades do porto. Outros fatos citados em requerimentos datados de 1879 a 1883 e apresentados como causadores de problemas à circulação de meios de transporte (bondes e carroças) foram a ausência de calçamento, ruas muito estreitas e a proibição de tráfego de veículos em determinados dias e horários.

O trabalho dos condutores e comerciantes era proibido durante os domingos e feriados. As mudanças ocorridas na cidade, no entanto, rapidamente afetariam o ritmo da dinâmica citadina. Os dias de descanso, feriados nacionais e religiosos, passaram a ser vistos pelos comerciantes como épocas favoráveis à circulação de produtos e abertura de lojas. Um ofício de abril de 1881, feito coletivamente por algumas casas importadoras, pediu a anulação de um artigo do Código de Posturas que proibia o trânsito de carroças nos domingos e dias santificados. Segundo o requerimento, a disposição do Código prejudicaria "os interesses do comércio, motivando até a diminuição dos paquetes que se destinam ao porto". Dessa forma, proibições que puniam com multas as casas de comércio que abrissem suas portas aos domingos e feriados (ou "dias de festas", como consta nos requerimentos), fizeram com que pedidos de revogação, da parte de diversos negociantes, chegassem à administração municipal repetidamente nas últimas décadas do século XIX. Em 1894, a Câmara, levando em consideração os pedidos dos comerciantes, permitiu que as casas comerciais permanecessem abertas até o meio-dia dos domingos e feriados (ANDRADE, 1989, p. 87).

A conformação do porto também sofreu alterações significativas nos anos derradeiros do século XIX. Inicialmente, principalmente durante a década de 1870, a construção de pontes e o prolongamento do comprimento das mesmas foram requisições feitas constantemente pelos negociantes ligados ao comércio exterior. Geralmente, as iniciativas de construção e prolongamento partiam das próprias firmas que, ao enviarem um requerimento à Câmara Municipal, precisavam de parecer favorável da Capitania dos Portos para que se desse a realização da obra no ponto escolhido pelos proprietários.

O porto, cada vez mais movimentado, deveria integrar-se ao sistema de transporte proporcionado pela construção da ferrovia. A situação portuária era, porém, de calamidade: 
com seus trapiches e longas pontes de madeira, o porto tinha se transformado em grave obstáculo ao movimento do café. O cenário começaria a se modificar em 1888 quando um grupo de empresários sediado no Rio de Janeiro e capitaneados por J. Pinto de Oliveira, Eduardo Guinle e Cândido Gaffrée vencem a concorrência aberta pelo então governo imperial para a execução das reformas portuárias. A concorrência pública, pautando-se em projeto elaborado em 1879 por Silva Sabóia como revisão de projeto anteriormente elaborado pelo engenheiro inglês W. Milnor Roberts, autorizava obras que constavam de um cais corrido entre um extremo da ponte velha da São Paulo Railway e a rua Brás Cubas, reservando-se ao longo dele uma faixa de 20 metros de largura para o depósito de mercadorias durante as operações de carga e descarga (SALES, 1999, p. 92). Os primeiros 260 metros de cais de pedra foram concluídos e inaugurados em 1892 (GITAHY, 1992).

A obra, no entanto, iria extrapolar as reivindicações das elites locais santistas, representadas pela Associação Comercial, entidade criada em 1870 e de grande influência na política local, gerando diversos conflitos. A conflituosa relação entre planície e planalto representados aqui pelas cidades de Santos e São Paulo, respectivamente -, e entre os poderes locais e os poderes estadual e federal seria uma constante no processo de transformação do espaço urbano da cidade de Santos. Curioso notar que, posteriormente, essa tensa relação política e econômica teria sua versão no campo esportivo, assumindo a feição de contendas e rivalidades surgidas e constantemente realimentadas entre os clubes dedicados ao futebol em Santos e as equipes paulistanas.

A defesa do monopólio da Companhia, auto-instituída representante do governo da União - segundo relatório de sua diretoria datado de 1908, "não sujeita às leis do Estado, nem às leis e autoridades do município" (HONORATO, 1997, p. 75) - baseava-se na idéia de que "toda a porção do litoral que for necessária ao serviço do porto, constitui um privilégio exclusivo" (SALES, 1999, p. 94). Assim, independente de novas concorrências, o primeiro núcleo de concessão foi sendo sucessivamente ampliado. A amplitude dos termos da concessão obtida em 1888 pela Companhia ultrapassara as reivindicações das elites locais e levaria, inevitavelmente, à supressão total do rentável negócio do sistema de pontes e trapiches iniciado três décadas antes.

Nesse sentido, o termo "Dokopolis", cunhado no começo do século XX pela linguagem jornalística operária de oposição à Companhia talvez sintetize sem grandes exageros a força e abrangência das intervenções levadas a cabo pela empresa. O domínio portuário, estendendose por toda a extensão dos terrenos marinhos, cortaria de forma quase absoluta o acesso da 
cidade ao litoral. Segundo trecho da edição de 09 de julho de 1904 do jornal O Diário de Santos:

\footnotetext{
"a empresa começou apoderando-se de todo o litoral do porto e, pouco a pouco, foi se estendendo até os Outeirinhos. A cidade ficou sem livre acesso até o porto e quem lá quiser ir tem de ser hóspede da Companhia, que the mandará assim abrir seus pesados portões de ferro. Nas noites de diversão, em que a sociedade de sport náutico realiza suas festas venezianas, o nosso povo tem de ir lá para o Paquetá, para contemplar os encantadores barcos. E procura-se o Paquetá por enquanto, pois o Paquetá também pertence à Companhia que por ali prolongou suas obras, as quais concluídas terá seu litoral isolado da cidade pelos armazéns e pelas grades. A cidade não tem servidão propriamente sua para o porto: este tornou-se propriedade da Companhia e esta munida de excepcionais privilégios avança resolutamente, plantando-se definitivamente no solo que bem quiser."
}

A posição defendida pelo jornal é paradigmática da relação, certamente conflituosa, estabelecida entre grande capital, representado pela Docas, e a municipalidade, representada especialmente pela Associação Comercial. Os conflitos, como veremos adiante, seriam ainda mais intensos na relação da empresa com a classe trabalhadora local.

Nas palavras de Lanna (1996, p. 63), "se o porto se fechava fisicamente para a cidade através das ações da Companhia, excluindo parcela significativa dos comerciantes locais de sua exploração, ele se abria, ou melhor, integrava-se e estimulava as radicais transformações que estavam ocorrendo no quadro urbano mais global, caracterizando o momento de ruptura da cidade em relação ao seu passado colonial".

Progressivamente, a Companhia Docas de Santos - popularmente conhecida como o "polvo" - esticava e espalhava seus tentáculos pela cidade. Além da "modernização" portuária, a Docas atuou em diversos pontos da cidade, reivindicando para si "propriedade de terras, até mesmo nos morros, direitos de exploração de pedreiras no bairro do Jabaquara, concessão de linhas de bonde e o monopólio de fornecimento de energia elétrica." (LANNA, 1996, p. 59 60). Portanto, além dos problemas de reestruturação do espaço que as obras do porto impunham à cidade, suprimindo as pontes e trapiches, reposicionando edifícios e equipamentos, sucessivos embates jurídicos em torno dos termos da concessão oporiam a Câmara Municipal, o Governo do Estado, a União, as Associações Comerciais de Santos e de São Paulo, a São Paulo Railway e a Companhia Docas (SALES, 1999, p. 130). Se a "composição" 
dos atores de cada uma das confrontações jurídicas seria definida a partir da possibilidade de obtenção de privilégios e benefícios próprios, parece certo, como afirma Gitahy (1992), que por ocasião da eclosão de diversas greves, esses grandes interesses acabariam unindo forças para, como afirma o Relatório do ano de 1905 da Companhia Docas, "terminar com as desordens que aqui se desenrolaram". (HONORATO, 1997, p. 145)

Nesse período, as atividades relacionadas ao café envolviam a quase todos na cidade. 0 crescimento da cidade e a oferta de serviços urbanos eram condicionados, entretanto, ao caráter portuário do município. Se por um lado o porto era visto como a porta de entrada para a modernidade, para o desenvolvimento e como forma de garantir a expansão econômica do município, por outro, o problema das epidemias que assolavam a região e, a partir da década de 1890, começavam a "subir a serra" através da ferrovia invadindo capital e interior do estado ameaçando a prosperidade gerada pelo café, transformava-se rapidamente em preocupação central das autoridades locais e estaduais.

A reforma e ampliação do porto eram constantemente apresentadas não apenas como soluções para o desenvolvimento econômico da região mediante a maior agilidade nas exportações de café e na recepção de trabalhadores vindos do exterior, mas também como parte integrante de um grande projeto de transformação urbana caracterizada pela necessidade de saneamento de uma cidade insalubre.

\subsection{0 "inimigo traiçoeiro": epidemias e as propostas de intervenção}

Em mensagem dirigida ao Legislativo de São Paulo em abril de 1892, o então presidente do estado, José Alves de Cerqueira César, expressava a sua preocupação com a situação de calamidade da cidade de Santos e alertava para a necessidade de medidas de saneamento. Segundo ele, "as epidemias perturbam a economia do estado, ameaçam a comunicação com o exterior e expõem o território paulista à invasão da febre amarela". Os temores de Cerqueira César eram corroborados pelos poderes e instâncias locais. A Associação Comercial de Santos, em apelo feito ao Presidente da Província de São Paulo em 1889, destacava que não só a vida da população estava em jogo, mas também que "altos interesses econômicos e financeiros do porto, da capital da Província e do interior corriam sério risco" (GONÇALVES, 1995, p. 32). Em ofício de 17 de março do mesmo ano, a Comissão de Vigilância Sanitária de Santos, em relatório também endereçado ao Presidente da Província, apontava a necessidade de intervenção governamental que tornaria a cidade apta a "repelir o inimigo traiçoeiro que 
aparecendo entre nós aniquila milhares de vidas preciosas, trazendo ao mesmo tempo o terror e com ele avultado prejuízo no comércio".

O problema das epidemias não era novo. Em um ofício da Câmara Municipal de Santos transcrito em ata datada de 24 de março de 1876, alguns cônsules e vice-cônsules estrangeiros solicitaram providências para "cessar o depósito de imundícies e matérias fecais nas praias". Eles atribuíam o aparecimento de alguns focos de febre amarela em navios atracados no porto de Santos à falta de limpeza do litoral. Em resposta, a Câmara afirmou que colocaria em prática medidas efetivas de descarte de "despejos da terra", utilizando-se de vigias de fiscalização. A municipalidade acrescentou ainda que não havia se descuidado da salubridade da cidade ao aterrar e calçar a maior parte das ruas, cobrir os ribeiros e valas públicas, "realizando em extensa área um sistema regular de drainage", concluindo que todas as medidas tomadas em âmbito local se tornariam ineficazes caso não fosse construído o cais reivindicado "em nome dos interesses do comércio e da saúde pública".

Nesse sentido, não se pode desvincular a tão reivindicada reforma do porto da situação geral do estado de São Paulo. Tanto nas reformas portuárias quanto nas intervenções sanitárias estava em jogo mais do que o grave problema de saúde pública existente em Santos, mas também a estratégica posição da cidade na relação com o planalto seja para escoar mercadorias, seja para importar trabalhadores.

Testemunha ocular, Guilherme Álvaro, médico sanitarista do Hospital de Isolamento, nos oferece valioso depoimento sobre a condição da cidade em 1889:

Em 1889, Santos, que havia se desenvolvido à revelia de quaisquer planos ou cuidados sanitários dos seus dirigentes, contava com 20.000 habitantes alojados em 2.000 casas, compreendidas as dos arrabaldes da Barra, Vila Mathias e Vila Macuco nascentes. A cidade ainda não possuía esgotos, tinha poucas ruas calçadas, quase todas mal niveladas e sem sarjetas capazes de promoverem o escoamento das águas pluviais, donde freqüentes inundações ocorriam nas épocas de chuvas. A água do abastecimento público já era escassa, usando-se ainda os poços que crivavam os pátios e os quintais, ao lado das fossas latrinas. (...) O aspecto de Santos era ainda francamente colonial, do tipo mais antiquado. As praias sujas, negras, lodosas, eram o repositório de quase todo o lixo da cidade. Para fazer o transporte do café, o número de carroças havia aumentado, fazendo crescer também o número de cocheiras, construídas também ao acaso, com pranchões e telhas de zinco, quase sempre como complemento dos cortiços, 
sem água e sem esgotos, abafadas e insalubres, sem asseio de espécie alguma. (ÁLVARO, 1919, p. 33-35)

Na década seguinte, o cenário descrito pelo médico não seria muito diferente. Entre 1890 e 1900 morreram em virtude das epidemias 22.588 pessoas na cidade de Santos (ÁLVARO, 1919, p. 24). Este número correspondia a quase metade da população do município no período.

A sucessão de epidemias que assolaram Santos durante quase seis décadas (segundo Guilherme Álvaro, já citado, houve uma epidemia de febre amarela na cidade na década de 1840) significou um de seus mais sérios problemas. Entre 1889 e 1898, as taxas de mortalidade foram sempre superiores às taxas de natalidade (ÁLVARO, 1919, p. 45). Embora a cidade continuasse a crescer demograficamente devido aos abundantes fluxos migratórios, a situação de saúde pública conjugada às perdas econômicas associadas tornaram a situação insustentável. A situação de calamidade era tal que navios atracados no porto eram obrigados a fazer quarentena (GITAHY, 1992, p. 22), obviamente afetando o comércio, principal fonte de riqueza na cidade.

A simples presença das moléstias e os problemas decorrentes não foram, no entanto, suficientes para que medidas práticas e abrangentes fossem tomadas em seu combate. Sobre isso, Ana Lucia Duarte Lanna afirma que:

“(...) somente quando, através da ferrovia que transportava agilmente o progresso e suas mazelas, as epidemias começaram a assolar o interior do estado e a comprometer o funcionamento do porto de exportação, é que intervenções radicais, violentas, mas eficientes do ponto de vista epidêmico, foram implementadas. As epidemias colocavam em risco a solução do problema dos braços para a lavoura." (1996, p. 71)

O aumento das exportações dos produtos vindos da província de São Paulo já colocava a cidade de Santos como foco de atuação dos governos estadual e federal desde a década de 1870. Santos, ao mesmo tempo em que prometia se tornar a cidade com o principal porto do país, era uma das mais difíceis de se intervir, seja pela relação conflituosa com a administração local, seja em virtude da gravidade e extensão das epidemias. 


\subsection{Planos urbanísticos e as disputas por um projeto de cidade}

A cidade de Santos foi uma das primeiras cidades brasileiras a ter um plano urbanístico de conjunto (BERNARDINI, 2003, p. 4). O esforço em estabelecer a abrangente reforma e a expansão da cidade advinha do insistente desejo de criar um novo sítio urbano e uma nova possibilidade de ocupação e exploração do território, condicionando essa busca a um tipo de desenvolvimento que privilegiasse a consolidação de um modo de vida burguês. Tanto em Santos como em outras cidades brasileiras, - talvez o caso mais emblemático seja a reforma urbana da capital federal durante a administração Pereira Passos - esse modelo estava pautado por uma economia urbana em expansão. O plano de saneamento, melhoramentos e extensão que seria realizado na cidade de Santos, elaborado pelo engenheiro sanitarista Francisco Saturnino Rodrigues de Brito e por ele executado na segunda metade da década de 1900, constituiu a primeira obra do urbanismo moderno em nosso país (ANDRADE, 1993, p. $55)$.

O primeiro plano sanitário elaborado para a cidade de Santos, entretanto, foi realizado por Estevan Fuertes, engenheiro e professor da Universidade de Cornell, nos Estados Unidos. Durante a década de 1890, Fuertes apresentou minucioso estudo sobre a questão sanitária santista. Em pesquisa sobre o tema, Sidney Bernardini aponta que, para o engenheiro:

\footnotetext{
"os problemas sanitários eram decorrentes de uma nova ordem estabelecida com o incremento das atividades urbanas. Assistia-se a um desenvolvimento econômico voltado à abertura do mercado de exportação do café, contribuindo para que a parte excedente do capital fosse investida em atividades e infraestruturação urbana. A concentração populacional nas cidades abria um canal para o avanço das epidemias, justificando as operações promovidas pelo Estado, em associação com os representantes do grande capital." (2003, p. 18)
}

No relatório apresentado às autoridades paulistas, o engenheiro estadunidense reputa as péssimas condições sanitárias da cidade às seguintes causas: a falta de ação efetiva da administração municipal; os esgotos imperfeitos e incompletos; o volume insuficiente de água potável; o calçamento impróprio; a falta de drenagem na região portuária e a falta de planejamento na construção de edificações (GAMBETA, 1984, p. 17).

Essas novas configurações, apontadas pelos relatórios de Fuertes, indicam que as questões urbanas, no início do século XX, eram mais complexas que a simples melhoria das 
condições higiênicas dos espaços. É importante lembrar que as formas de intervenção do período não se resumiram aos chamados projetos ou planos urbanos de conjunto, mas se estenderam para os instrumentos de controle, como os códigos sanitários, de postura e os serviços sanitários, instituídos em muitas cidades brasileiras, refletindo o modelo de cidade salubre, bela e moderna (LANNA, 1996 e CAMPOS, 2001).

Ainda na década de 1890, o processo de saneamento e higienização da cidade seria iniciado pelo governo estadual. Sob responsabilidade da Secretaria dos Negócios do Interior ficaria a Comissão Sanitária (ver imagem 9, p. 50), incumbida da função de vistoriar habitações, promover desinfecções, fiscalizar a limpeza de terrenos. A Comissão de Saneamento, ligada à Secretaria da Agricultura, era responsável pelas obras de canalização de água e construção da rede de esgotos. Fuertes havia trabalhado para a Comissão de Saneamento, assim como Saturnino de Brito, responsável por posterior e ainda mais amplo plano urbanístico para a cidade (BERNARDINI, 2003 e ANDRADE, 1989). Em 1897 vem à luz o Código de Posturas Santista que, ao lado do Código Sanitário do Estado, reforçava o poder da polícia sanitária. As intervenções higienistas sobre os cortiços existentes na cidade sucederam-se de modo violento e autoritário, conjugando-se com propostas de construções de vilas operárias que tampouco foram levadas a termo (ANDRADE, 1992).

Em Santos, assim como no já citado Rio de Janeiro durante a administração de Pereira Passos, a remodelação portuária veio acompanhada de uma política de intervenção urbana com forte cunho sanitarista e que acabava por segregar e excluir a população pobre (GAMBETA, 1984, p. 19).

O problema central, como apontado por Lanna (1996), era como tratar essa população diversa e, ao mesmo tempo, livre e igual em direitos e como lidar com essas diferenças sem alterar os lugares sociais. Se antes, nas cidades ditas "coloniais", a nítida demarcação social entre senhores e escravos permitia um intercâmbio de relações entre as esferas pública e privada, na cidade dita "moderna" era necessário excluir do espaço público os ex-escravos, agora livres, mas diferentes na condição econômica, controlando e segregando espaços por eles ocupados - e por pessoas pobres de um modo geral -, segmentando socialmente a cidade e promovendo um novo modelo de circulação, através das intervenções urbanas, entre os diversos espaços. Ao conferir à cidade um novo papel, concretizado pela fixação e aumento da população urbana e pela expansão de seus territórios, os processos sociais e políticos então em curso iluminam o sentido de muitas das intervenções que se realizaram nas cidades brasileiras levando em conta este novo modus vivendi pautado pela inserção do Brasil em uma economia capitalista internacional. 
Saturnino de Brito, partidário de uma concepção global de cidade, elaborou para Santos uma planta geral. Em seu projeto, a preocupação social, assim como a dimensão estética, estava subordinada à imperiosidade da técnica. Segundo Carlos Roberto Monteiro de Andrade (1992):

\footnotetext{
"com o plano de saneamento, melhoramentos e expansão que Saturnino de Brito elaborou e implantou em Santos, mesmo que não tendo sido integralmente realizado em todos os seus aspectos, não apenas temos a construção de uma cidade moderna, mas a aplicação de princípios urbanísticos considerados revolucionários para a época. Desaparece o passado colonial da cidade em nome de um futuro marcado pelas concepções de higiene e progresso." (1992, p. 32)
}

Brito preconizava o planejamento como modo de assegurar uma dinâmica de desenvolvimento harmônico para o crescimento das cidades. Na sua concepção, seria necessária uma mudança da cidade como um todo, redefinindo o conjunto de sua estrutura urbana. Seus projetos e obras de saneamento, dos quais se destacam os canais de drenagem das águas pluviais como elementos estruturadores do espaço urbano, não apenas propiciavam condições de salubridade ao meio físico, eliminando as causas das epidemias, mas, ao mesmo tempo, colocavam a necessidade de previsão sistemática do crescimento das cidades - daí a exigência dos chamados "planos gerais" apoiados em minuciosos levantamentos topográficos - e constituíam uma nova paisagem urbana, marcada pela presença de equipamentos sanitários e pela configuração de uma cidade ordenada e limpa, instaurando novos espaços públicos em uma nova cenografia urbana.

As realizações de Brito deram origem a uma nova cidade com desenho extremamente moderno para a época, aproximando a paisagem urbana santista daquela de cidades européias (ANDRADE, 1993 e CARRIÇO, 2015). Suas preocupações ultrapassavam as questões de salubridade e saneamento, se estendendo à preocupação do engenheiro com o embelezamento e o ordenamento espacial da cidade em harmonia com o sítio geográfico (FARIA, 2015, p. 115). A solução dos canais (ver imagens 11 e 12, p. 51), por exemplo, não apenas viabilizou o enxugamento da planície e assim a criação de uma ampla área para a expansão da cidade, em condições adequadas de saneamento, mas também definiu a estrutura básica de seu sistema viário. Ladeados por avenidas e calçadas arborizadas, os canais 
de Brito eram navegáveis por embarcações simples e que funcionavam como meio de transporte. Com seus passeios laterais, pontes e passadiços, os canais de Santos possibilitavam novas práticas sociais e despertavam novas formas de sensibilidade e sociabilidade modernas (COSTA, 2000). Segundo um cronista da época:

\footnotetext{
"esses canais, ora retos, atravessando o terreno de ponta a ponta, ora desviados aqui e ali, por conveniência técnica ou disposição topográfica, incumbem-se de drenar o subsolo e produzir o enxugo superficial (observese aqui que, em um sítio cuja rede hidrográfica é praticamente indefinida, como em Santos, inexistindo rios que marcam a cidade atravessando-a e recolhendo suas águas, o canal constrói o rio, revelando toda a artificialidade da paisagem). Aí está a primeira condição do saneamento para a ocupação do espaço. Acresce que esses canais preenchendo a sua função principal são também verdadeiras avenidas e, o que é melhor, veículos de canalização de ar, permitindo a renovação constante desse fundamental elemento vivificador. O progresso consigna, por outro lado, além de um forte xadrez de ruas longitudinais e transversais, esplêndidas avenidas que são outros tantos condutores de oxigênio regenerador afora o que há nelas sob o ponto de vista da sociabilidade e da civilização magníficos centros de passeio e de gozo recreativo (Apud: ANDRADE 1993, p. 573)
}

Progresso, civilização, sociabilidade. Interessante notar no excerto citado a articulação de elementos basilares da concepção urbanística de então. Dos canais às largas avenidas, "condutores de oxigênio regenerador", ao combate feroz promovido contra habitações coletivas, populares fundamentalmente, os planos e ações de intervenção modificavam, em curto espaço de tempo, a paisagem urbana santista.

Caberia ao urbanismo disciplinar os comportamentos sociais tanto nos espaços públicos quanto nos espaços privados através da socialização do sentimento de intimidade e da negação de toda e qualquer "promiscuidade" - representada essencialmente pelos cortiços e habitações coletivas - sobretudo através das ações dos higienistas e demais reformadores sociais (BONDUKI, 1998 e MELOSI, 2000).

Essa perspectiva "legitimava uma política repressiva e destruidora das formas de vida e associação, sobretudo das classes trabalhadoras" (LANNA, 1996, p. 79). A discussão e posterior configuração de uma cidade higiênica e bela e a associação entre salubridade física e social foi 
uma das formas fundamentais de generalização dos valores burgueses e de controle sobre essa população mais pobre, móvel e instável (COSTA, 2000). É sobre essa população fragilizada que as intervenções pretensamente modernizadoras recairiam com mais violência, definindo lugares e funções sociais. Essa nova redistribuição social, constantemente atualizada no intenso ritmo das intervenções sanitárias, desenharia o espectro da prática futebolística santista das primeiras décadas do século XX. Desnecessário enfatizar aqui que o futebol se introduziu no Brasil, apesar de suas especificidades locais, principalmente como modismo europeu com fortes traços higienistas, moralistas e de distinção social mais adequada, portanto, aos jovens da elite. Nosso processo de popularização do futebol, entretanto, apresentou ritmo próprio, condizente com os limites de uma sociedade ainda fortemente marcada por heranças coloniais e escravistas, com sua rigidez, hierarquias e intensa exclusão das camadas empobrecidas. Nesse sentido, como veremos mais adiante, tanto a prática do futebol como a localização e arquitetura dos primeiros estádios da cidade de Santos respeitavam a lógica de ocupação e destinação de espaços caracterizada pelas transformações urbanas do período (MATOS, 2005).

Não apenas os espaços deveriam ser saneados e "modernizados", mas a imposição de uma nova racionalidade expressa nas reformas urbanas representaria a possibilidade de construção de "novos homens", adequados à ideia de modernidade que se pretendia instaurar (PERROT, 1988 e GAMBETTA, 1988).

Esse amplo processo, para além das demolições e do "bota-abaixo", criaria um novo espaço urbano. Uma cidade concebida para o progresso, com amplos espaços abertos, praças, largas avenidas, jardins, canais. Descobriam-se novos lazeres através da fruição de uma cidade disciplinada. Descobria-se a praia - local que abrigaria as primeiras partidas de futebol registradas na cidade - e a vida à beira-mar. Criava-se uma cidade mais segmentada socialmente. Consolidava-se uma população empobrecida considerada pelo saber científico hegemônico de então promíscua, perigosa. Resistia essa população. Negava a vacinação obrigatória, a transferência forçada de moradia, a perda quase absoluta dos já restritos espaços de lazer e o controle sobre seu trabalho. De pequenas resistências cotidianas a algumas das maiores e mais importantes manifestações operárias de seu tempo - as greves de trabalhadores da construção civil e portuários como pontas de lança - eram recorrentes as estratégias a esse amplo cenário de mudança que os afetava diretamente, mas não os incluía (LANNA, 1996 e GAMBETA, 1984). 


\subsection{A cidade em transformação: ampliação dos limites físicos e redefinição dos espaços urbanos}

Norbert Elias, ao analisar a passagem da civilidade para a civilização, concebe esse processo como uma dinâmica de dominação social que se impõe tanto para fora quanto para dentro dos espaços nacionais e que vai, progressivamente, eliminando as possibilidades de existência das diferenças (1990, p. 32). Entre o final do século XIX e o início do século XX, as reformas urbanas que caracterizaram cidades como Santos e Rio de Janeiro foram marcadas pela semelhança das propostas e pela violência das intervenções. A materialização de certa ideia de civilização - na chave proposta por Elias - e progresso eram recursos legitimadores dessas intervenções. É dessa forma que podemos entender a cidade como a expressão visual de uma certa classe social, como projeção dos seus valores no espaço (BONDUKI, 1998, p. 79).

A modernidade que se pretendia instaurar era identificada através da remodelação física do espaço urbano e se materializava em novas praças, bulevares, jardins à beira-mar e largas avenidas. Pela primeira vez depois de mais de três séculos e meio de sua fundação, o então povoado, agora cidade, expandia seus limites. As demolições, os loteamentos e a nova configuração de bairros e ruas indicavam um movimento no qual a terra passava a ser vista como mercadoria (COSTA, 2000, p. 147). Apareceria, com força, a especulação imobiliária. $\mathrm{Na}$ reordenação de espaços públicos e privados revelaram-se as novas formas de viver e estar na cidade. As mudanças nas formas de lazer e nas formas de morar - com o combate aos cortiços e instauração da casa como ente essencialmente particular e privado - demonstravam a existência de um movimento na direção de se criar, especialmente em uma cidade conhecida nacionalmente pela presença de combativa classe trabalhadora, uma população de habitantes/espectadores passivos, observadores da modernidade que se almejava (LANNA, 1996, p. 75).

Procuraremos, nas próximas linhas, aprofundar a análise sobre as contradições e conflitos em torno da expansão da cidade que, em pouco tempo, se tornaria um dos centros irradiadores do futebol brasileiro.

A cidade de Santos já passava por um processo de alteração espacial antes mesmo que as mudanças no modelo político brasileiro começassem a se delinear. As demolições nas áreas centrais foram os primeiros sinais dessas mudanças:

“As demolições vão ocorrer no que o dicionário definia como zona urbana. Começaram em 1869 pelo local de fundação da cidade - o Outeiro de Santa 
Catarina. A justificativa era a transformação do beco de Santa Catarina em rua, ligando-o à Rua da Constituição. Assim seriam demarcadas ruas e quadras em xadrez desde os Quartéis até a região do Paquetá. As demolições continuaram acontecendo nos pontos que marcavam os limites e referências da então cidade colonial. O convento do Valongo teve parte de sua área alterada para dar lugar à ferrovia e os armazéns de sal foram demolidos para alargar a Rua José Ricardo em 1883." (LANNA, 1996, p. 92)

O processo de transformação da cidade tem nas freqüentes demolições um elemento fundamental para sua compreensão. A simples definição do que era considerado um empecilho ao desenvolvimento urbano, do que deveria ser preservado e do que deveria ir abaixo nos fornece valiosas indicações sobre as intenções existentes sobre o espaço físico santista. As demolições e reconstruções vão instituindo novas memórias compartilhadas socialmente e novos marcos de referência, elegendo o que deveria ser valorizado ou relegado ao esquecimento.

Assim como na França revolucionária estudada por Robert Darnton (1998), foi intensa na cidade de Santos a substituição de nomes que evocavam o uso do lugar para o de figuras ilustres do início do período republicano. Apagava-se assim parte da memória associada ao passado colonial e imperial e à escravidão. Colocavam-se no lugar datas e heróis assumidos pela República, referências da história que se pretendia construir.

As demolições, iniciadas já na década de 1860 pelo local de fundação da cidade conhecido como Outeiro de Santa Catarina, se intensificaram nas décadas de 1890 e 1900. Nesse período, a antiga Igreja Matriz dá lugar ao novo prédio da Alfândega e à Praça da República. As antigas ruas Direita e Santo Antônio, importantes vias comerciais próximas ao porto, foram rebatizadas, respectivamente, de rua XV de Novembro e rua do Comércio (ver imagens 3 e 4, p. 47). Nesse período a cidade já possuía duas largas avenidas, a Ana Costa (ver imagem 6, p. 48) e a Conselheiro Nébias, essa última a única via a ligar diretamente a região das praias ao porto. A construção de novos símbolos, deslocando ou subjugando antigos monumentos, fazia parte de uma espécie de ressignificação e, em certa medida, negação do passado. Prevaleceria a associação entre estética e higiene, marcas do pensamento urbanístico da época (BERNARDINI, 2003 e COSTA, 2000).

A cidade começava a se expandir para além de sua área central, através do prolongamento de vias, da construção de novas avenidas e da progressiva formação de novos bairros, como é o caso da Vila Macuco, implantada a partir de meados da década de 1880. 
A expansão desse novo espaço urbano revelaria, entretanto, algumas das mais acentuadas características da sociedade santista no período. Uma delas é a relação conflituosa com o governo estadual e a constante busca local por autonomia.

O poder político em Santos era constituído por interesses diversos que ora se refletiam em posições contrárias ao governo estadual (o que ocorria com mais freqüência), ora eram complementares a ele, ainda que de forma bastante restrita e isolada, configurando-se apenas em estratégia de luta.

As posições contrárias, contudo, tiveram caráter de disputa pelo poder e pela busca de autonomia política. Nesse ponto, Santos constituiu uma das cidades mais fervorosas na defesa da autonomia municipal, recusando-se em alguns momentos a aceitar as prerrogativas centralizadoras do governo estadual. Havia por trás disso uma forte disputa de interesses econômicos, mais acirrada que em qualquer outra cidade do Estado, revelando que no rearranjo econômico em expansão as dissidências estavam fortemente instaladas nos grupos políticos santistas e paulistas. (BERNARDINI, 2003 e MATOS, 2005). Santos é apontada como uma das cidades proeminentes na luta pela destituição imperial, tendo sido palco da atuação de lideranças importantes, precursores ou integrantes dos movimentos de base republicanos, como Silva Jardim, Augusto Fomm e Xavier da Silveira.

A defesa da autonomia local nos primeiros anos da República resultou em um curioso ato: a promulgação da primeira Constituição Municipal do país. A chamada "Carta Magna Municipal" (ver imagem 10, p. 50), nas palavras de Vicente de Carvalho, responsável por sua elaboração, pretendia estabelecer, entre outras coisas, a recuperação urbanística e sanitária da cidade conjugada à independência econômica e financeira que possibilitaria realizar as reformas necessárias ao desenvolvimento local.

A promulgação dessa Constituição levou o município a ser o primeiro a eleger um prefeito e um vice-prefeito, ainda em 1894, quando as municipalidades ainda tinham o seu executivo organizado pelas intendências.

Interessante notar como essa conflituosa relação e a defesa da autonomia local teriam, especialmente nos anos 1910, a sua representação nos gramados paulistas. 0 surgimento e consolidação do Santos Futebol Clube como potência futebolística regional cumpriria papel fundamental nesse sentido. Constantemente apresentado pela grande imprensa comercial como o "time da cidade", o clube passa a ser tratado como uma espécie de "defensor" dos interesses locais contra as interferências e imposições vindas do planalto. Discutiremos essa questão em mais pormenores no terceiro capítulo desse trabalho. 
A relação conflituosa com o governo estadual se manifestaria em diversas outras situações, seja nas disputas pelos planos urbanísticos a serem implementados, seja pela íntima relação mantida por algumas grandes empresas com o governo sediado na capital paulista. Sobre esse segundo aspecto, o caso mais sintomático é o da Companhia City of Santos Improvements.

A atuação da Companhia City em Santos foi marcada pela entrada do capital estrangeiro na organização dos serviços de abastecimento de água e iluminação pública naquela cidade. $O$ investimento maciço de capital estrangeiro em alguns ramos de serviços denotava, além disso, a monopolização e certo controle sobre o Estado, já que as concessões quase sempre incluíam privilégios para as companhias estrangeiras, uma maneira concreta de implementar serviços públicos. A trajetória dessa companhia começa em 1870 por iniciativa do brasileiro Domingos Moutinho. Nesse ano, Moutinho adquiriu a concessão, segundo Lei Provincial, para explorar o serviço de bondes a tração animal em Santos por cinqüenta anos. No mesmo ano, Moutinho criou para essa finalidade a Companhia de Melhoramentos de Santos, adquirida já no ano seguinte pelos investidores Frederic Russell, Thomas Cochrane e pelo engenheiro Everett Benest.

Após 1870, várias outras empresas começaram a operar o transporte coletivo em Santos, condicionando a expansão da malha urbana à possibilidade de ampliação da rede de transportes para além da cidade então existente.

Em 1880, alguns investidores ingleses fundaram a Companhia City of Santos Improvements Co Ltd., destinada à exploração de serviços públicos. Já no ano seguinte a City incorporou ao seu patrimônio a Companhia de Melhoramentos de Santos, passando a prestar os serviços de água, iluminação a gás e transporte de passageiros sobre trilhos. (ANDRADE, 1995, p. 101)

A concessão de funcionamento da City no país representou um dos primeiros passos para a pretendida modernização da cidade, que até então não contava sequer com distribuição de água adequada à parcela considerável de seus habitantes. A compra da Companhia Melhoramentos pela City não representou, no entanto, melhorias significativas nessa questão. A população, nas últimas décadas do século XIX, crescia vertiginosamente, demandando a expansão de serviços básicos, como o abastecimento de água, o que não ocorria. A administração municipal chegou a refazer o contrato com a City já em 1886, obrigando-a a ampliar seus investimentos em infraestrutura e fornecer água em quantidade e qualidade suficiente aos moradores da cidade. Esse seria apenas o primeiro dos muitos 
episódios de desgaste e conflito entre a municipalidade e os interesses da City na cidade de Santos.

Ao longo de décadas, várias foram as tentativas de acabar com o monopólio da empresa, que durou até 1953 sem que nenhum concorrente a atrapalhasse, quando finalmente entregou os serviços ao Estado. Mathias Costa e a própria Companhia Docas de Santos haviam tentado quebrar esse monopólio, o primeiro para levar uma linha de bondes ao bairro que leva o seu nome e a segunda para instalar serviços de iluminação pública. (LANNA, 1996, p. 95)

Apesar das constantes reclamações da administração municipal contra os serviços prestados pela Companhia e até de eventuais sublevações populares contra sua atuação como no caso dos violentos protestos de 1894 em virtude do aumento de tarifas promovido pela Companhia - a manutenção dos serviços prestados pela City contava com a anuência e apoio quase irrestrito do governo estadual. A explicação para isso pode estar contida nas seguidas manifestações de interesse da Companhia em expandir a cidade, implementar novas linhas de bonde e estender a rede de abastecimento e iluminação a gás. Se a municipalidade, que era responsável pelo controle da iluminação pública e do abastecimento de água, manifestava incessantemente sua insatisfação pela má execução contratual da City, o governo estadual nem sequer abordava a questão em seus relatórios até 1896, quando, embora de forma superficial, citou o problema de funcionamento de parte da rede de esgotos. (BERNARDINI, 2003, p. 205)

Além dos serviços de abastecimento de água, carro-chefe da empresa quando da sua criação, e iluminação pública, a Companhia City era responsável pelo transporte por bondes em Santos. A instalação de linhas foi um dos investimentos mais rentáveis da Companhia, associando-a à expansão da malha urbana.

A City limitou-se a atuar em Santos, adquirindo ao longo dos anos - como vimos anteriormente -, desde que se constituíra em 1881, o monopólio sobre os serviços de abastecimento de água, iluminação pública e transporte público. A partir de 1910, a empresa passou a monopolizar efetivamente a rede de transportes de Santos, ao passo que as outras áreas de atuação da City estiveram em intensa disputa - litigiosa, em alguns casos - com as outras duas empresas de grande capital com atuação na cidade: a Companhia Docas e a Companhia Construtora de Santos (SAES, 1979, p. 110). O interesse de expandir a malha urbana e constituir ligações físicas com a região da Barra (ou região das praias) condicionou o pensamento no interior da Câmara Municipal. Se a união de interesses entre a City e o governo estadual incidiu diretamente sobre o planejamento e o desenvolvimento urbano, 
fazendo crescer a atuação empresarial nesse setor, a atuação da municipalidade também foi decisiva no processo de configuração da nova cidade que se formava.

A elaboração do Plano Municipal de 1896 (ver imagem 19, p. 55) nos fornece interessantes indícios sobre essa questão.

O plano elaborado pela Câmara Municipal de Santos para a cidade em 1896 foi uma demonstração de que a municipalidade tinha interesse em desenvolver o núcleo urbano, consolidando-o como uma cidade moderna. Embora as questões sanitárias - as epidemias no início da década de 1890 atingiram o ápice de sua letalidade - ainda estivessem longe de serem resolvidas, a intenção de estender a cidade para além de seus limites se tornara prioridade e provocaria, em pouco tempo, alterações radicais no espaço urbano existente. Demolições de prédios antigos e alinhamento de ruas passaram a ser práticas rotineiras no setor de obras públicas da Câmara Municipal no período. (BERNARDINI, 2003, p. 214)

As demolições e reconstruções, claramente identificadas com a possibilidade de trocar a cidade colonial por uma cidade dita moderna, numa atitude simbólica de poder, estavam relacionadas à efetiva implementação de uma nova estrutura, que tinha na circulação, na intensificação do comércio, na facilitação das trocas e no avanço da população suas razões mais profundas. E mesmo a intenção de ordenar a cidade, muitas vezes, fugia ao controle dos órgãos de poder. Foi assim em relação aos cortiços, por exemplo.

Já em 1893, a Câmara Municipal de Santos pronunciava-se declarando que o alinhamento e nivelamento das habitações eram importantes, seja para o embelezamento, seja para facilitar a boa circulação de ar pela cidade. No entanto, as situações em que os particulares transgrediam essas regras eram inúmeras, como indicam as próprias atas da Câmara Municipal do período. A discrepância entre a normatividade do poder público e a realidade cotidiana dos cidadãos que ora procuravam se adaptar a essa nova ordem, ora a recusavam abertamente, resultava em diversos conflitos. As constantes prescrições e um constante esforço presente nas leis e nos códigos visando imprimir à cidade uma certa idéia de racionalidade encontrava nas atividades cotidianas de seus habitantes o seu principal entrave.

A idéia de um espaço racional, controlável e circunscrito a regras fixas foi um dos importantes componentes na origem do planejamento urbano moderno no Brasil. O plano, como manifestação de um pensamento racional sobre a projeção de futuro da cidade, também conviveu desde cedo com as constantes transgressões (CAMPOS, 2001 e COSTA, 2000). 
O Plano Municipal de 1896 começa a ser colocado em prática efetivamente após a contratação, pela Câmara Municipal de Santos, do engenheiro José Brant de Carvalho, convidado a assumir a chefia do setor de obras públicas da Câmara.

Poucos dias após a contratação de Brant, o então presidente da Câmara, vereador Antônio Iguatemy Martins, faria interessante pronunciamento, indicando certa mudança de rumo na relação quase sempre conflituosa da municipalidade com o governo estadual:

\footnotetext{
“Como sabeis, é indiscutível e inadiável a necessidade de dar uma solução urgente que reclama os serviços de construção de uma nova rede de esgotos e de abastecimento de água e bem assim os de drenagem e demais trabalhos indispensáveis ao saneamento desta cidade. Isso justifica por certo todo o concurso prestado pela Câmara, facilitando as ações do governo estadual na realização de tais melhoramentos. (...) Enquanto o saneamento de Santos não for fato consumado, é iminente o risco e o perigo que corre a laboriosa população desta cidade, tão cruelmente flagelada pelas epidemias. O Estado de São Paulo, por seu próprio orgulho e vaidade não quererá que se diga mais tarde que, não obstante sua riqueza, o seu progresso e seu pujante desenvolvimento, assemelha-se ele ao vil avarento que aparentando andrajos, oculta os seus tesouros; que tem à sua porta, à sua entrada, quase unida à sua capital, uma triste necrópole que afugenta os estrangeiros e a desacredita perante as nações civilizadas. Não, assim se dirá, confiemos nos méritos e provada competência de quem tem hoje sobre os ombros o pesado encargo da alta administração do Estado. Esperamos, pois, sem desanimar, o saneamento de Santos será uma realidade.
}

O discurso de Martins, em nome da Câmara Municipal de Santos, diferente do tom conflituoso geralmente característico das relações entre a municipalidade e o governo estadual, dessa vez alterna entre a cobrança e a colaboração, visando o início imediato das obras de saneamento, sem as quais o Plano de expansão da malha urbana não seria possível.

A resposta efetiva do governo estadual, entretanto, tardaria, apesar dos apelos dos vereadores santistas. Pouco mais de um ano após o primeiro pronunciamento, o ainda presidente da Câmara, Antônio Iguatemy Martins, afirmava que: 


\begin{abstract}
"Se a Câmara Municipal não puder ou não quiser chamar a si a execução de tais obras, jamais será Santos saneada e deverá contentar-se com o grande auxílio indireto que nos têm prestado as obras do cais e aconselhar aos crentes que implorem à Providência Divina para que não nos falte com freqüentes chuvas e verões benignos. Esta é a verdade, por mais dura e cruel que nos pareça, e oxalá o futuro possa desmentir-nos por completo"
\end{abstract}

Sem o apoio do governo estadual, a Câmara acelerava o processo de execução de um Plano Municipal sob a responsabilidade de José Brant de Carvalho. O plano era acompanhado de várias outras propostas além da expansão do núcleo inicial através de ruas e praças. Pretendia-se com ele não só prolongar as ruas, mas enfrentar o problema das moradias precárias. O plano abrangia projetos para a construção de mercados, moradias econômicas para operários, melhoramentos nas avenidas Conselheiro Nébias e Ana Costa, posto médico, abertura de novas ruas, arruamento entre a região central e a Barra e a elaboração de um novo Código de Posturas.

O desenho proposto para a cidade era como uma complementação do desenho sanitário criado pelo governo estadual, mas não se restringia à idéia de um plano sanitário, tendo a intenção de ser mais abrangente do ponto de vista urbanístico. A proposta da Câmara, nesse sentido, serviria mais como um documento orientador, um conjunto de diretrizes para orientar o crescimento da cidade a partir da atuação do capital privado.

Um exemplo disso é o projeto para habitações operárias. O relatório, bastante vago sobre um tema que passaria pelos recursos da administração pública, não indicava nem mesmo os locais prováveis para sua construção, indicando apenas a necessidade de se criar alternativas aos cortiços.

Brant, na justificativa do projeto, não explica as razões para o traçado e as diretrizes criadas. Somente alguns anos mais tarde, com Saturnino de Brito (como veremos adiante), é que se introduziu um pensamento mais sistematizado acerca das formas urbanas e dos desenhos da cidade.

As articulações com o capital privado, embora implícitas, dão o tom de boa parte do plano desenvolvido. Seguindo orientações anteriores do governo estadual em defesa da abertura de ruas até a Barra como forma de higienizar a cidade e fazer circular o ar, havia concretamente uma tendência de desenvolvimento em direção à Barra impulsionada por dois vetores: a presença de empresas privadas operando bondes a vapor e o prolongamento de avenidas como Conselheiro Nébias e Ana Costa. Delineava-se uma forma de intervenção de 
peso, na qual as companhias construtoras poderiam atuar. Curiosamente, pouco tempo depois, o próprio José Brant de Carvalho deixaria o seu posto na seção de obras e passaria ao setor privado, onde participaria ao lado de outros engenheiros da concorrência para as obras de esgoto em 1900.

O dinheiro das companhias privadas de construção e transporte parecia seguir o fluxo dos trilhos dos bondes santistas (ver imagem 6, p. 48).

Em 1891, havia mais de cinco empresas operando bondes na região. Mais tarde, voltaria às mãos da Companhia City, que passaria a monopolizar todas as linhas de transporte em Santos, como citado anteriormente. Percebe-se que, dessas linhas, foram surgindo bairros e vilas ao redor dos pontos de parada dos bondes, como o bairro do Gonzaga que surgiu ao redor de um botequim, ponto de parada da linha que vinha da Vila Mathias (ver imagem 5, p. 48). O bairro só floresceu a partir da abertura das avenidas e dos posteriores canais. Logo, os investidores vislumbrariam, como em outras regiões da cidade que se expandia, uma oportunidade, possibilitada pelas novas redes de acesso e higienização da cidade.

Fundamental nesse processo foi a urbanização das avenidas Ana Costa e Conselheiro Nébias. Uma das prioridades do projeto de Brant, a idéia era dotar essas duas vias de todos os melhoramentos urbanos, tornando-as eixos importantes de ligação entre a região central da ilha e a Barra. A Câmara esperava concluir rapidamente as obras para estimular, nos eixos dessas avenidas, novas construções, desenvolvendo outro padrão de urbanização com espaços mais amplos e higienizados. Não por acaso, essas duas longas avenidas tratadas pela administração pública como prioritárias se tornariam elementos centrais para o desenvolvimento de atividades esportivas na cidade. Utilizadas para a prática - e para competições - de ciclismo desde fins do século XIX, elas seriam palco da gênese do futebol santista. Ao longo de sua extensão, surgiriam os primeiros campos de futebol da cidade, principais espaços para essa finalidade até a inauguração do estádio do Santos Futebol Clube na segunda metade da década de 1910.

O novo modelo proposto pelo Plano de 1896 estava, portanto, relacionado também à viabilização de outras funções que a cidade podia oferecer. Tratava-se de abrir caminho ao lazer naquele setor inabitado até então, mas, além disso, tratava-se de construir um outro tipo de cidade, na qual o lazer era parte simbólica. As avenidas largas teriam seus espaços preenchidos pelas novidades do fim de século: as bicicletas como meio de locomoção e depois, conforme citado, como atividade esportiva, a iluminação elétrica, os cafés, os botequins, os restaurantes, enfim, os símbolos materiais da inserção citadina no campo da modernidade. 
Anos mais tarde, a materialização de certa idéia de modernidade na cidade das longas e largas avenidas encontraria em conjuntos de bolas e chuteiras um de seus referenciais. Seria ali, na Barra recém ocupada e nas avenidas da virada de século que o futebol se tornaria rapidamente uma mania local. Discutiremos essa questão mais adiante.

As prioridades do plano idealizado por Brant, no entanto, refletiam as contradições e desnudavam o caráter autoritário das intervenções. O projeto de lei declarava de utilidade pública todos os terrenos necessários à abertura e prolongamentos de ruas. Nascia um plano de expansão de caráter ordenador, de regulação do crescimento e do sentido da ocupação de espaços.

As formas de controle urbano expostas no plano de Brant encontrariam na esfera legal um de seus elementos paradigmáticos.

Poucos mecanismos de poder podem ser comparados aos corpos legais que passaram a ser incorporados às políticas de controle e intervenção públicas no final do século XIX e no início do século XX. As leis que então eram elaboradas intensificavam o caráter de controle urbanístico da sociedade, no momento em que os ambientes urbanos começavam a ser o palco dos acontecimentos e para onde as atenções estavam voltadas. A cidade era também, a partir do final do século $\mathrm{XIX}$, o lugar do trabalhador livre que deveria estar circunscrito às regras de civilidade (ROLNIK, 1997, p. 13).

A partir de meados da década de 1890, as leis passaram a tratar sistematicamente das formas de controle urbano na cidade de Santos, coincidindo com o aumento da letalidade provocada pelas epidemias de febre amarela e com a intervenção mais recorrente do governo estadual com as formações das Comissões Sanitária e de Saneamento. A transformação física da cidade também recebeu a influência das leis promulgadas nesse período, através da desapropriação de áreas de particulares para a extensão e alargamento de vias, como propunha o plano de Brant. Porém, foram os códigos de postura que melhor representariam os meios de controle dos quais o poder público lançava mão. Esses códigos estabeleciam regras cujo objetivo era banir da cidade tudo o que não fosse contemplado pelo então projeto de modernidade - o de criação de uma cidade limpa, higienizada, ampla e elegante.

Santos, na década de 1890, foi caracterizada pela existência de dois instrumentos legais que possibilitaram as intervenções urbanas: o código sanitário estadual e o Código de Posturas de 1897. O Código Sanitário estadual, aprovado em 1894, incorporava as questões técnicas associadas a uma nova imagem de cidade, por preceitos estéticos e diretrizes políticas. O Código Sanitário versava sobre o estabelecimento de larguras mínimas para ruas e avenidas, padrões mínimos exigidos para as habitações e os parâmetros construtivos das 
edificações urbanas. O Código de Posturas santista, por sua vez, aprovado pela Câmara Municipal em 1897, viria a incorporar ao controle municipal muitas das disposições que o código estadual estabelecia. Ambos os instrumentos tratariam de forma bastante clara e incisiva sobre as habitações coletivas - os cortiços - e o saneamento necessário ao seu combate.

Em 1894, o então chefe da Comissão Sanitária, o médico Tolentino Filgueiras, havia se manifestado sobre essa relação em relatório sobre as condições sanitárias da cidade. Segundo ele:

\footnotetext{
"Toda a taverna ou venda tinha em seus quintais um corredor de supostas casinhas, denominadas cortiços. (...) A construção de tais casebres revoltounos logo pela simples observação exterior. Todos, ou quase todos, eram construídos com pedaços de tábuas de caixas de sabão ou batatas e folhas de zinco nas coberturas e mesmo nas paredes. Nenhum possuía assoalho, eram edificadas imediatamente sobre o solo, sendo que em muitas o chão achava-se transformado em lamaçal. Água, latrina e asseio eram coisas desconhecidas. Era tudo um horror." (Apud: BERNARDINI, 2003, p. 131)
}

As habitações agora ganhavam regulamentações em relação aos compartimentos internos, inclusive. $\mathrm{O}$ rigor em relação às peças sanitárias e dispositivos higiênicos indicava a tentativa de controle do poder público também no espaço privado das residências. A postura regulamentadora acentuava também a presença da classe trabalhadora na cidade. Os códigos indicavam que compartimentos que pudessem ser caracterizados como porões não poderiam ser de habitação. Esses espaços eram comumente utilizados por trabalhadores que moravam nas áreas centrais da cidade. Em alguns casos, os trabalhadores sublocavam esses espaços, agora alvos mais freqüentes das inspeções sanitárias. Começava-se a delinear um projeto de exclusão através da lei de tudo aquilo que não fosse considerado salubre e higiênico pelos Códigos. As imposições dos Códigos promoveram intensa reformulação nas edificações particulares, principalmente nas habitações coletivas da região central da cidade. Várias ações de despejo com a intenção de reformular os prédios e adaptá-los às novas exigências de salubridade e conforto foram realizadas pelo poder público (ANDRADE, 1989). Os procedimentos nessas inspeções, quase sempre violentos, provocavam reações da população em relação aos métodos de fiscais e inspetores encarregados, que se utilizavam de vigilância, intimação, multa, interdição, desalojamento e até demolição. A persuasão também 
foi um dos instrumentos utilizados e procurava neutralizar a resistência e buscar a identificação da população com o projeto sanitário (GAMBETA, 1988)

Os Códigos não eram apenas instrumentos de controle urbano, constituíam-se na base técnica da produção da cidade. Eles institucionalizavam uma espécie de cidade ideal, que deveria ser desejada e buscada com apoio de um corpo legal.

Surgem as licenças e alvarás de construção, colocando os proprietários sob a fiscalização do poder público.

As restrições apareciam de forma mais evidente (e abrangente) nas considerações sobre as habitações populares, especialmente as habitações coletivas. Brant, em seu projeto, delineou não apenas restrições às habitações coletivas existentes, mas estabeleceu normas para as novas que surgissem. Esses dispositivos buscavam, certamente, controlar os cortiços que proliferavam nas áreas urbanas densamente povoadas, como era a região central de Santos naquele período. Brant determinava que todas as edificações destinadas a um grande número de habitantes deveriam ser construídas fora da aglomeração urbana, inclusive as vilas e habitações operárias. O Código Sanitário já havia definido as habitações insalubres, tornando fácil para a administração pública intervir, já que os critérios eram bastante claros. Com a aprovação do projeto de lei criado a partir do plano de Brant, seria definido o contorno da área de aglomeração urbana e as áreas de expansão para prover a base legal de desmonte dos cortiços e a conseqüente expulsão da classe trabalhadora das áreas mais valorizadas para as regiões periféricas.

Apesar das prescrições - a Câmara tinha a intenção de, além de ordenar a expansão urbana, prever a construção de novas habitações na parte estendida do núcleo urbano, retirando os cortiços da área central -, as regiões centrais da cidade de Santos nunca deixaram de ser habitadas pela população trabalhadora.

Os anos 1890 seriam caracterizados pelo aparecimento dos primeiros loteamentos previstos para a classe trabalhadora. Descritos de forma bastante vaga no plano de Brant - o referido plano entendia como prioridade o combate aos cortiços, mas não especificava alternativas concretas de realocação da população trabalhadora - os loteamentos estavam associados à expansão da rede de transportes urbanos e eram geralmente explorados pela iniciativa privada, seja por empresas do setor de construção ou comprados por uma crescente camada de servidores públicos, negociantes ou funcionários qualificados dos quadros da Companhia Docas de Santos (HONORATO, 1997, p. 88). 
A forma como a cidade vai sendo progressivamente ocupada para além da sua região central através desses loteamentos será fundamental para a compreensão da consolidação, especialmente na década de 1910, da prática do futebol na cidade.

A nova paisagem da cidade ganharia seus definitivos contornos a partir do início do século XX através do trabalho desenvolvido pelo engenheiro Saturnino de Brito, considerado o precursor do urbanismo moderno no Brasil. (ANDRADE, 1992).

Saturnino de Brito assumiu a Comissão de Saneamento do Estado de São Paulo em 1905, embora o engenheiro tivesse contato com a cidade desde 1898, quando estudou a situação das epidemias no local e suas possíveis soluções. Curiosamente, nesse primeiro momento, Brito já denunciava algo que se tornaria recorrente em sua atuação na cidade: as interferências políticas sobre os trabalhos para o saneamento de Santos. Ainda no final do século XIX, o engenheiro se preocupava com a construção de uma nova paisagem e definia critérios para estender a cidade, divergindo do projeto aprovado pela Câmara Municipal em 1896, e esboçando - inclusive indicando a possibilidade de abertura de canais - as bases para o projeto que executaria a partir de 1905 (ver imagens 21 a 25, p. 56-58).

Independente de todas as idéias, propostas e intervenções até então realizadas pelo município e pelo Estado, o ano de 1905 foi um marco na transformação da paisagem de Santos, contrapondo-se à lentidão com que ambos haviam tratado o saneamento da cidade. Nesse ano, Brito efetivamente iniciou os trabalhos de saneamento de Santos.

Esse plano, inicialmente apresentado como uma compilação de estudos anteriores sobre a cidade, consistia basicamente em três conjuntos de obras: esgotos sanitários, reforma completas das instalações domiciliares e esgotos fluviais, esses últimos já com o esboço do que viriam a ser os canais de drenagem da cidade.

Ao mesmo tempo em que conduzia o início das obras que modificavam significativamente a paisagem urbana santista, Brito começava, de forma cuidadosa, a interferir definitivamente na vida política local. Era o começo de uma aproximação que o levaria, anos mais tarde, a ser questionado por grupos políticos locais. Até 1912, Brito construiu relações aparentemente harmoniosas com a cidade, ganhando entre negociantes e políticos locais adeptos voluntários da execução de seu plano. Embora Brito só encaminhasse à Câmara a planta desenvolvida para a cidade em 1910, já em 1906 apresentava o projeto completo de expansão da cidade, contando com parcela significativa dos vereadores para manter a lei que a previa (BERNARDINI, 2003, p. 265). As boas relações que mantinha com a Câmara, mesmo que ocasionais, permitiram-lhe, nesses primeiros anos de trabalho, desenvolver as obras. Os terrenos levantados estavam sendo cedidos gratuitamente pelos 
proprietários para as reformas realizadas. Entre esses proprietários locais, apareciam os nomes de Catarina Ablas, Luiza Macuco, João Antunes dos Santos e Belmiro Ribeiro (LANNA, 1996, p. 112) que seria, a partir de 1912, prefeito de Santos e um dos principais envolvidos na polêmica da Câmara com Brito para a aprovação da planta desenvolvida pelo engenheiro. Belmiro Ribeiro, que impediu a aprovação da planta anos mais tarde, cede em 1906 uma parte dos terrenos necessários para a execução dos canais de drenagem e das extensas avenidas laterais (ANDRADE, 1989, p. 96). Todos esses nomes, aliás, eram de futuros loteadores interessados na expansão que naturalmente valorizaria seus terrenos.

Na primeira década do século XX, Saturnino contou com a colaboração da Câmara para a introdução de uma série de leis que permitiram a execução completa do plano. Leis que permitiram e regularam desapropriações, a caracterização de quarteirões como insalubres e a especificação de vielas particulares faziam parte de um plano que indicava o crescimento da cidade, com novos desenhos de ocupação. Expansão essa que se realizava com uma rapidez nunca antes vista. Em 1906, concluía 815 metros de canal. No ano seguinte, a extensão já era de 2.028 metros. Quanto aos esgotos, em 1907 havia desenvolvido 26.013 metros e dois anos mais tarde o número já chegava a 66.804 metros (BRITO, 1943, p. 285).

Embora houvesse grande esforço de Saturnino de Brito em conduzir a execução das obras de forma meramente técnica, como indicam seus escritos (BRITO, 1943), a dimensão política regia todo o processo de implementação do plano.

As constantes tentativas de interferir nos projetos de Brito, especialmente a partir do início dos anos 1910, demonstram que os sentidos dados aos novos caminhos da cidade passavam por interesses diversos, principalmente de agentes privados com relações próximas com o poder público local. Exemplo disso foi o caso envolvendo Francisco Teixeira da Silva Telles, diretor de obras da Prefeitura de Santos nos primeiros anos da década de 1910. Silva Telles tinha interesse em desenvolver planos de pequenos loteamentos na cidade em parceria com Roberto Simonsen e o então prefeito Belmiro Ribeiro, com os quais monta, em 1912, a Companhia Construtora de Santos. Respaldado por Belmiro Ribeiro, exerce o poder de sua função e seu poder de articulação para recusar a planta desenvolvida por Brito no mesmo ano. As boas relações com a cidade e com a Câmara, que permitiram a desapropriação de terrenos para a execução das obras nos primeiros anos, se transformariam entre o final da década de 1900 e os primeiros anos da década de 1910 em uma relação de conflito que impediria o governo estadual através da figura de Brito de complementarem o plano idealizado e proposto para a cidade. 
Apesar das eventuais desavenças e dificuldades, os projetos desenvolvidos por Brito deixaram uma marca indelével na cidade. Os canais, talvez a referência máxima de Santos do ponto de vista urbanístico, são a materialização de sua influência. Em 1907, o governo inaugurou o primeiro canal (canal 1) com a extensão de dois quilômetros e mais duas avenidas arborizadas nas laterais. A inauguração levou uma multidão às ruas, como mostram todos os veículos de imprensa do período, e contou com o comparecimento de representantes do poder público paulista - senadores e deputados estaduais - junto a Saturnino de Brito (ver imagens 13 a 16, p. 52-53).

A execução dos canais de drenagem, imprimindo nova paisagem à cidade, era, no entanto, apenas parte do plano proposto, conforme entregue à Câmara santista em 1910, um ano após sua saída da Comissão de Saneamento. Apesar disso, é importante enfatizar que os canais foram estruturadores para o desenho da cidade, tornando-se até hoje a mais importante referência urbanística e simbólica de orientação de seus moradores.

A entrega da planta de Santos na Câmara Municipal, em 1910, marcava a transição entre uma reflexão abrangente sobre o desenho como forma unitária dotada de lógica interna para outro momento, marcado pela fragmentação e individualização dos investimentos urbanos em loteamentos e bairros, como aconteceria no caso da Vila Belmiro, primeiro loteamento concebido por Francisco Teixeira da Silva Telles, Belmiro Ribeiro e Roberto Simonsen, aprovado após grande polêmica com Saturnino de Brito e a Câmara Municipal. Esta não era mais do que o ajuste político com uma tendência que se constituía a partir de uma fração da elite - Telles, Simonsen e Ribeiro, por exemplo - que pretendia reproduzir seu capital em investimentos urbanos, na implantação de infra-estrutura e na abertura de novos arruamentos. A planta de 1910 (ver imagem 23, p. 57) representa, portanto, mais do que um ato político de aproximação entre governo estadual e municipal. Graças à habilidade política de Brito, notadamente um técnico, a planta é o resultado de uma série de inovações na construção do planejamento e na implementação do urbanismo moderno no Brasil (CAMPOS, 2001, COSTA, 2000 e ANDRADE, 1993).

Os projetos de Brito, pensados e elaborados para Santos ao longo de quase duas décadas, não estavam, naturalmente, isentas de interferências externas e distintos interesses. As controvérsias, como o caso Silva Telles, davam mostra do que seria a prática das grandes obras urbanas de engenharia durante o século XX (BONDUKI, 1998 e CERASOLI, 2004). Imerso pelos acordos firmados entre empresas fornecedoras e contratos de empreitada, Brito pôde conduzir as obras até um limite estabelecido pelos interesses dessa elite. Os investimentos vão sendo, progressivamente, direcionados a outras finalidades, a pequenos projetos de 
melhoramentos posteriores, à instalação de energia elétrica, à extensão das redes de transporte urbano e aos loteamentos, cada vez mais abrangentes. Da planta original, aproveitariam só o esqueleto.

As iniciativas do capital privado não se restringiriam, entretanto, à infra-estrutura urbana. O futebol, cada vez mais popular, se tornaria parte da esfera de atuação de grandes empresas sediadas na cidade. A partir de meados dos anos 1910, a construção de praças esportivas faria parte do amplo leque de atuação da Companhia Construtora de Santos. À expansão da malha urbana consolidava-se a expansão das agremiações dedicadas à prática do futebol. A Companhia de Simonsen não seria a única grande empresa a participar desse processo. A Companhia Docas, influente na cidade desde o final do século anterior, teria relevante papel nesse sentido. Os tentáculos do grande capital privado - como veremos em detalhes no capítulo derradeiro deste trabalho - se estenderiam aos gramados santistas.

Pouco a pouco, a cidade vai ganhando outros contornos e adquirindo novas feições. Loteamentos dão origem a bairros. A região central, antes o núcleo fundamental de ocupação, vai dividindo espaço com outras regiões (imagens 26 e 27, p. 58-59).

A Vila Matias foi o primeiro exemplo de bairro mais afastado das regiões centrais e dos morros a receber parte da classe trabalhadora local. A Vila Macuco, próxima ao cais e criada na década de 1880 , se notabilizou por receber predominantemente trabalhadores portuários a partir da década de 1900. Nela residia a maioria dos empregados diretos e indiretos da Companhia Docas. Considerado "arrabalde", o bairro do Macuco findava o perímetro urbano da cidade nos últimos anos do século XIX.

Novos bairros vão surgindo, quase sempre acompanhando o traçado de longas ruas, avenidas e canais. A longa e larga Rua Carvalho de Mendonça, por exemplo, deu origem a três bairros: a Vila Belmiro, entre 1910 e 1915, o Campo Grande, a partir de 1915, e o Marapé, no final da década de 1920 (ANDRADE, 1995, p. 99).

Lentamente, mas não sem violências, interesses e contradições, os espaços foram sendo redistribuídos e suas funções redefinidas. 


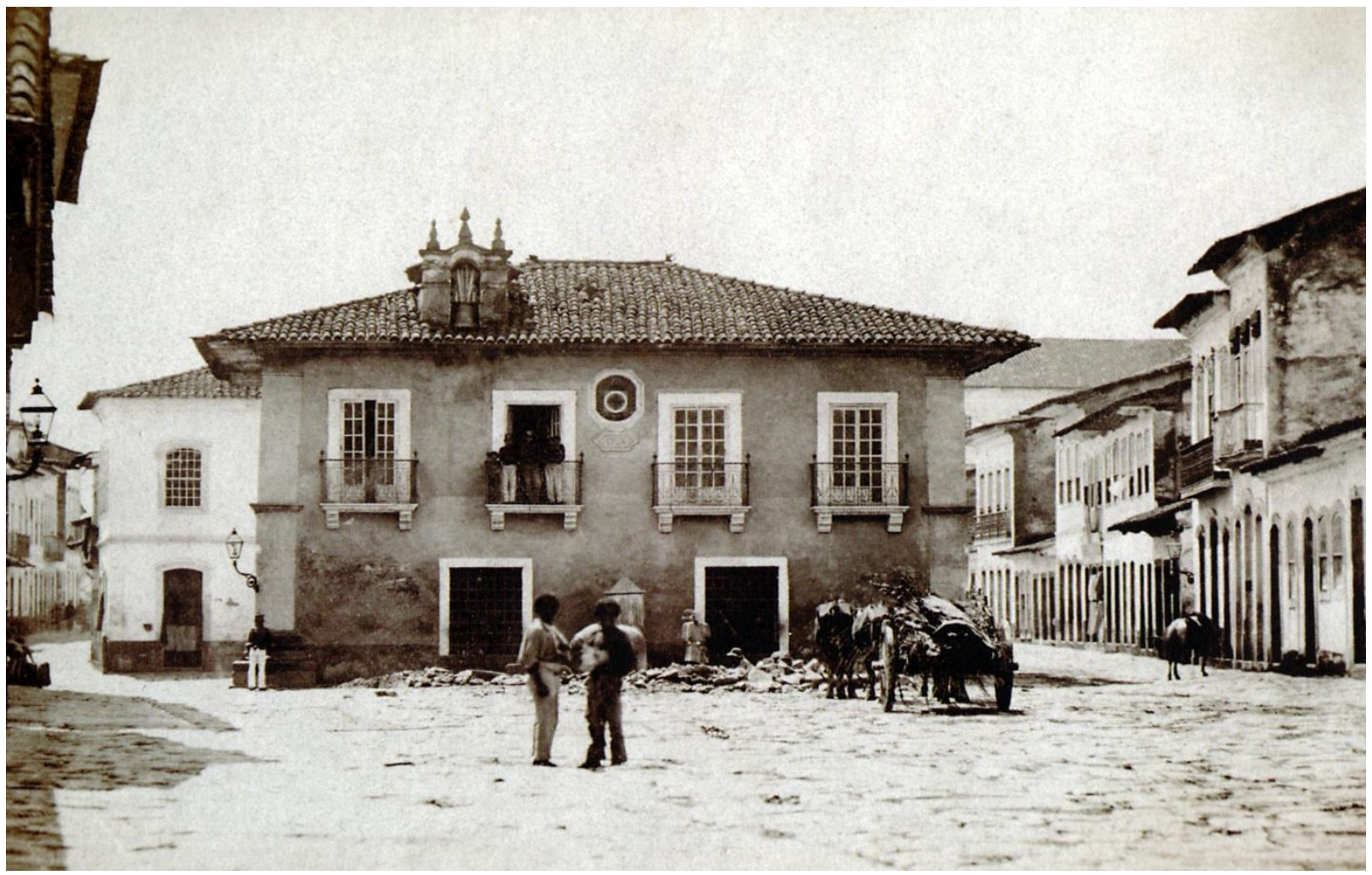

Imagem 1: Casa de Câmara e Cadeia, Década de 1880. Fonte: Fundação de Arquivo e Memória de Santos.

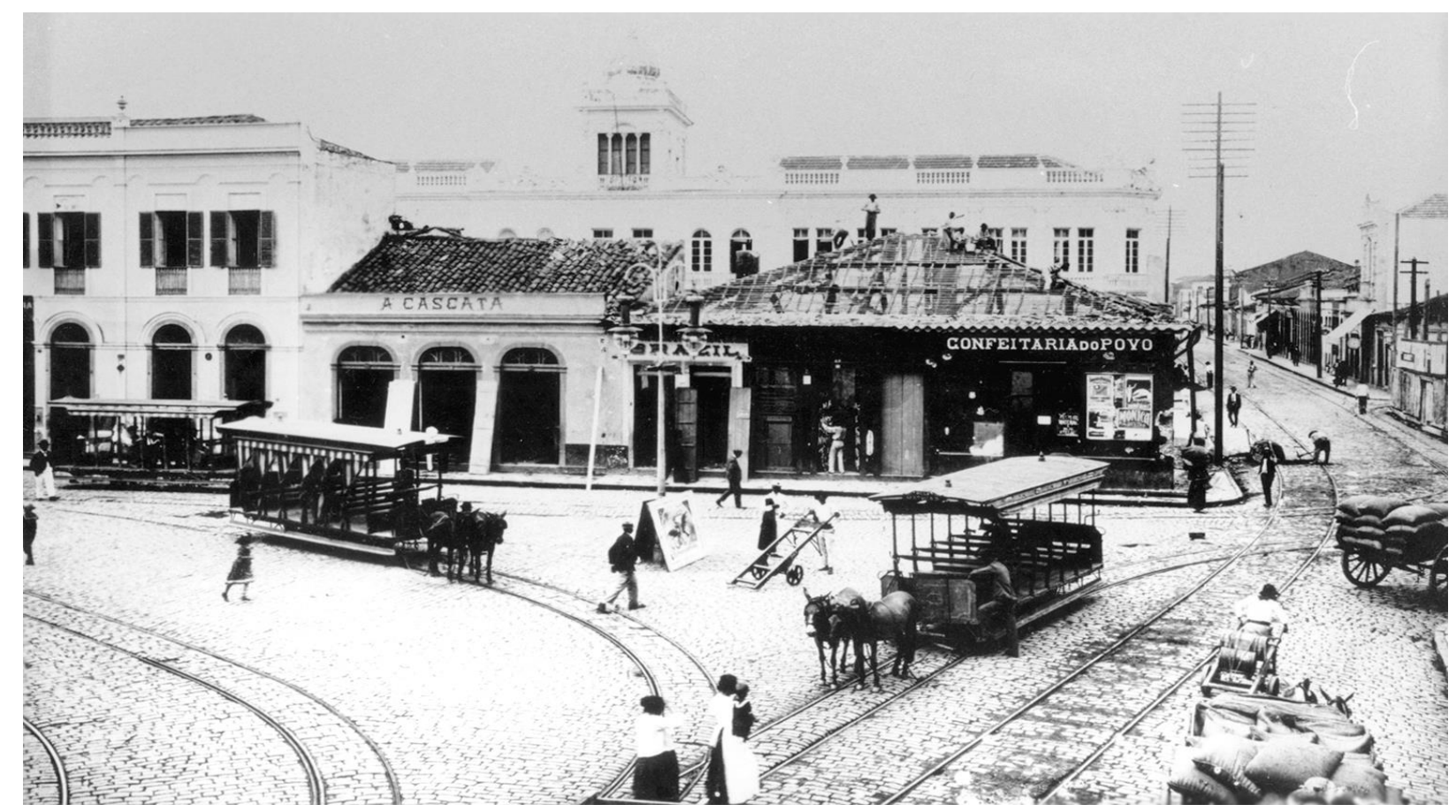

Imagem 2: Bondes no Largo do Rosário, Década de 1880. Fonte: Fundação de Arquivo e Memória de Santos. 


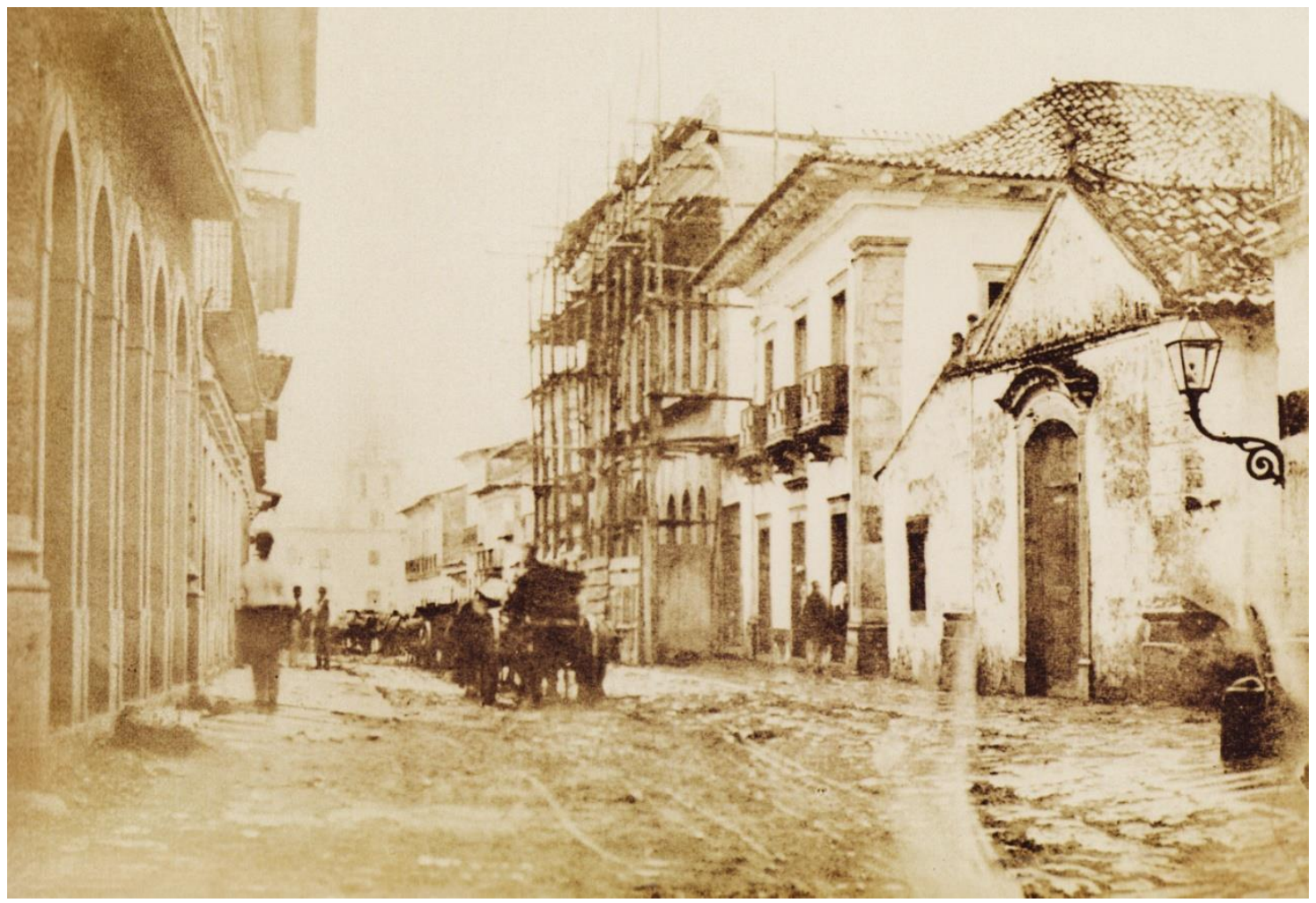

Imagem 3: Rua Santo Antônio (futura Rua do Comércio), Década de 1880. Fonte: Fundação de Arquivo e Memória de Santos.

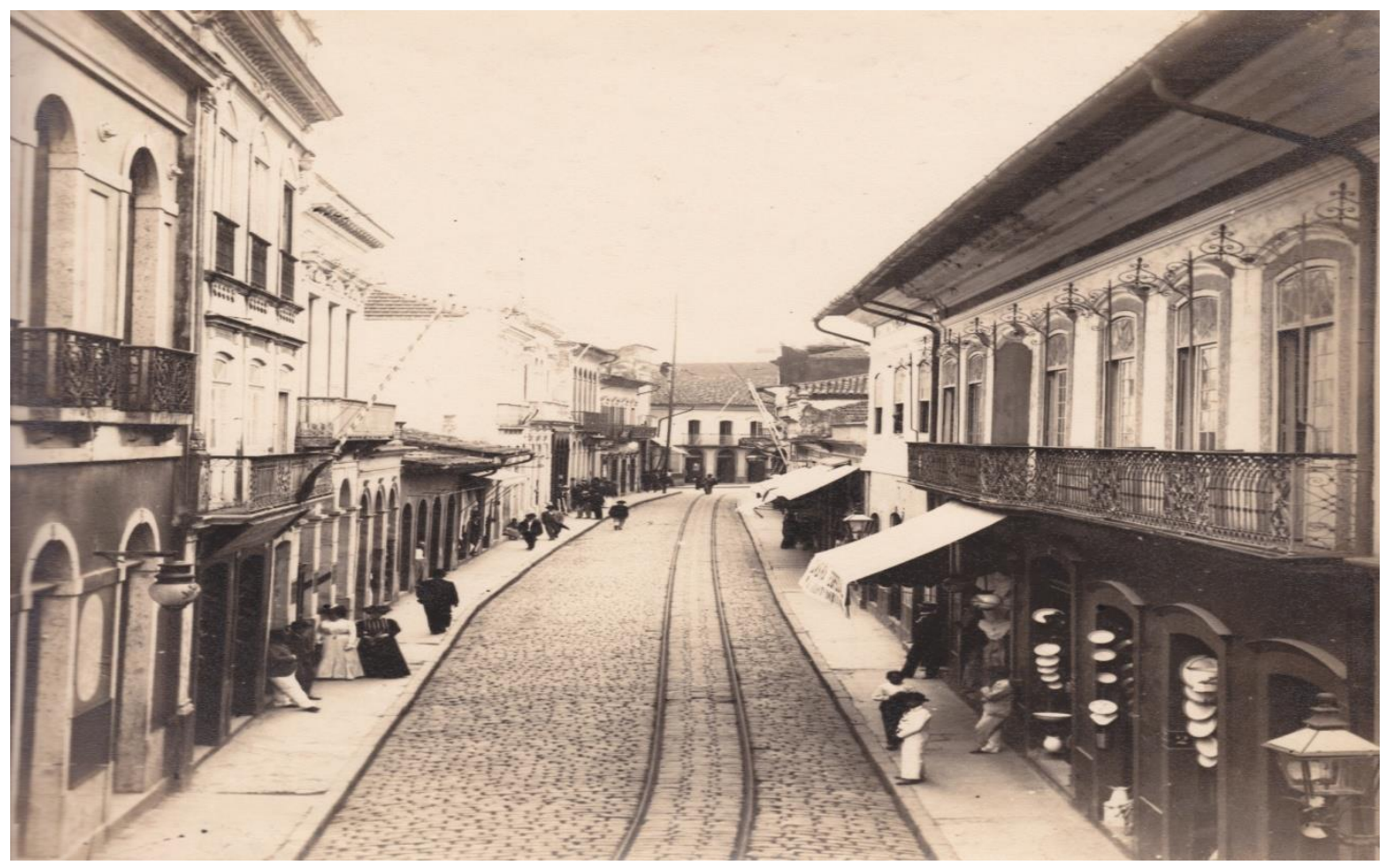

Imagem 4: Rua XV de Novembro, Década de 1890. Fonte: Fundação de Arquivo e Memória de Santos. 


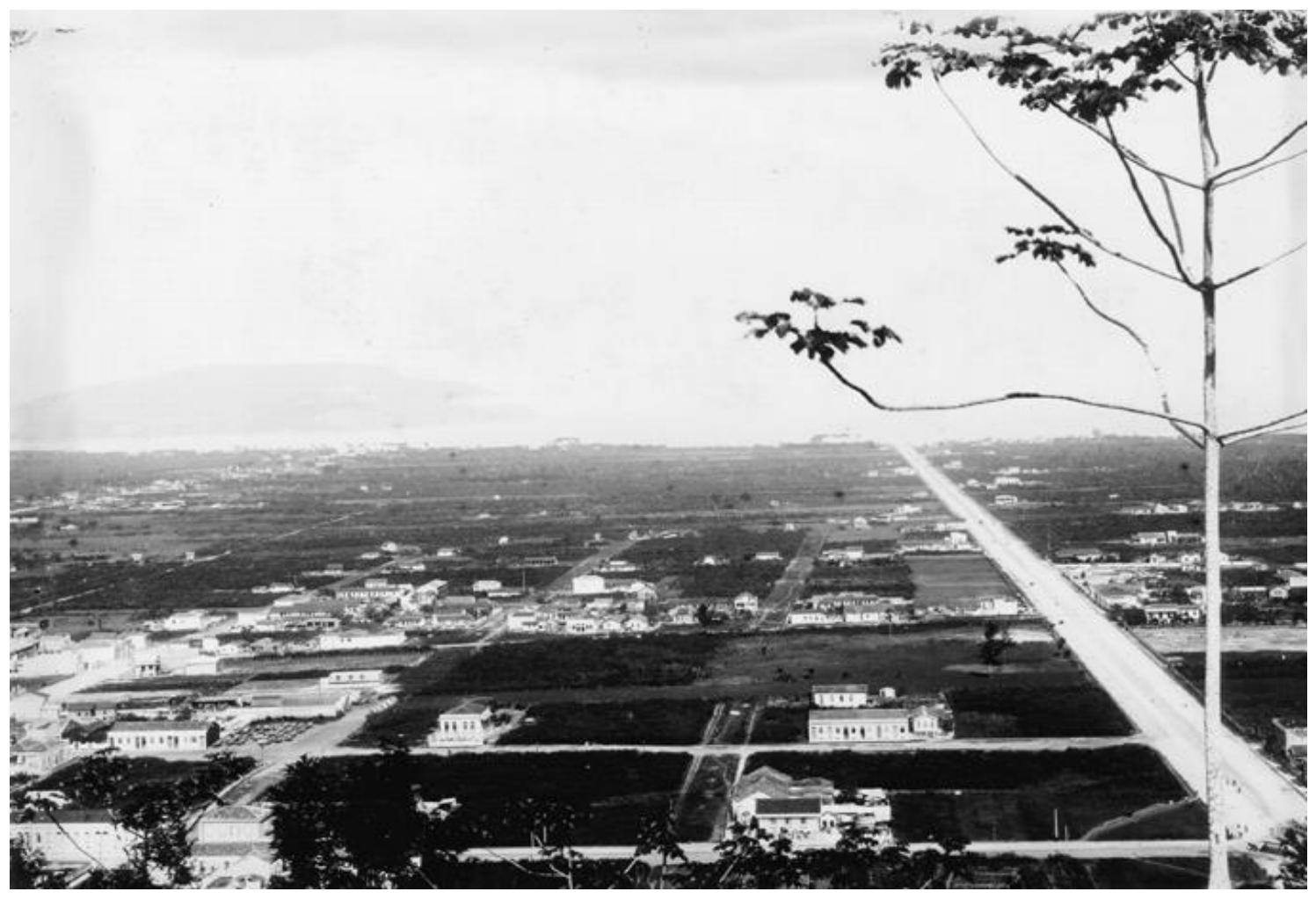

Imagem 5: Bairro de Vila Mathias, 1900. Fonte: Fundação de Arquivo e Memória de Santos.

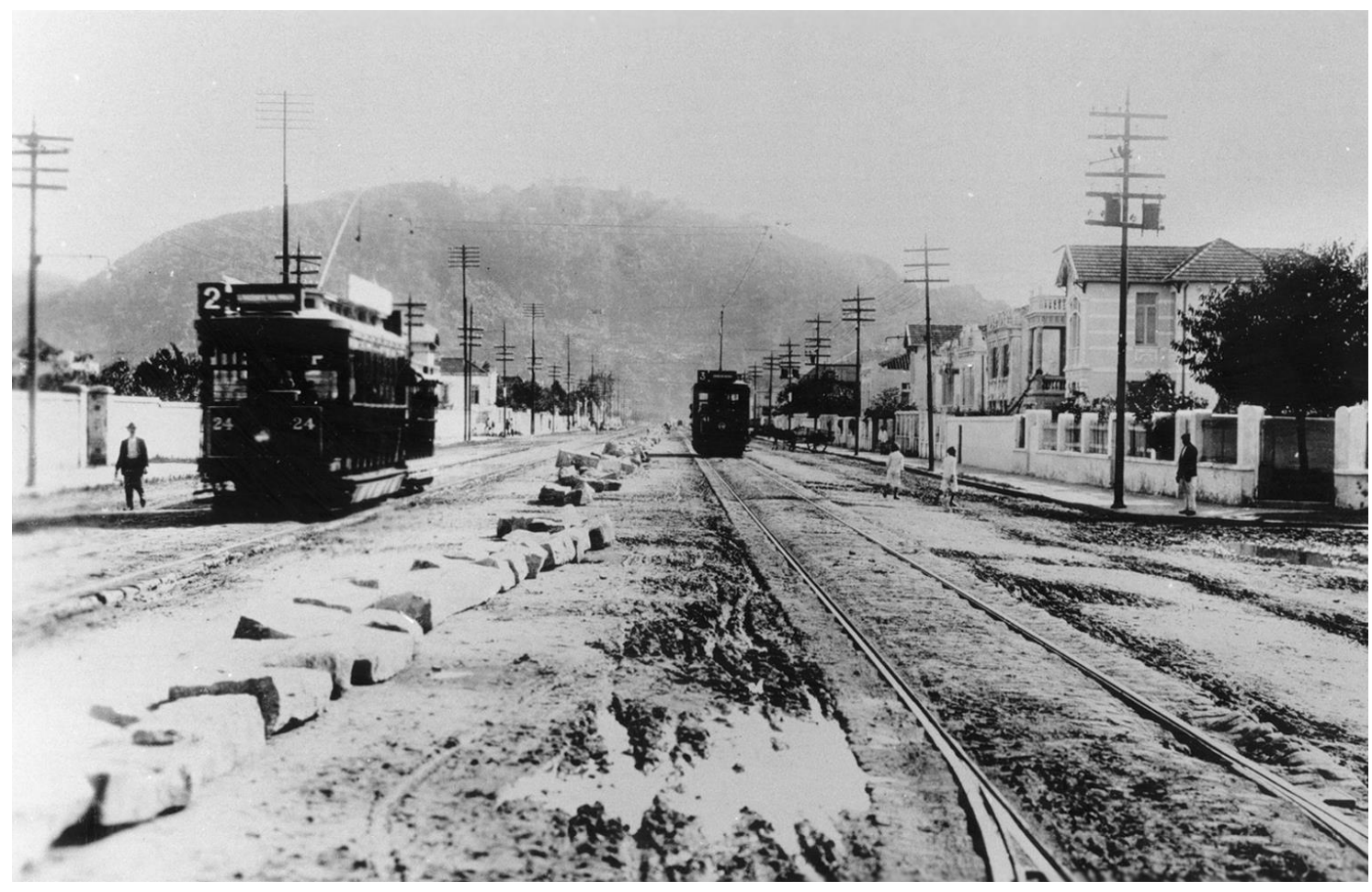

Imagem 6: Avenida Ana Costa. Década de 1900. Fonte: Fundação de Arquivo e Memória de Santos. 


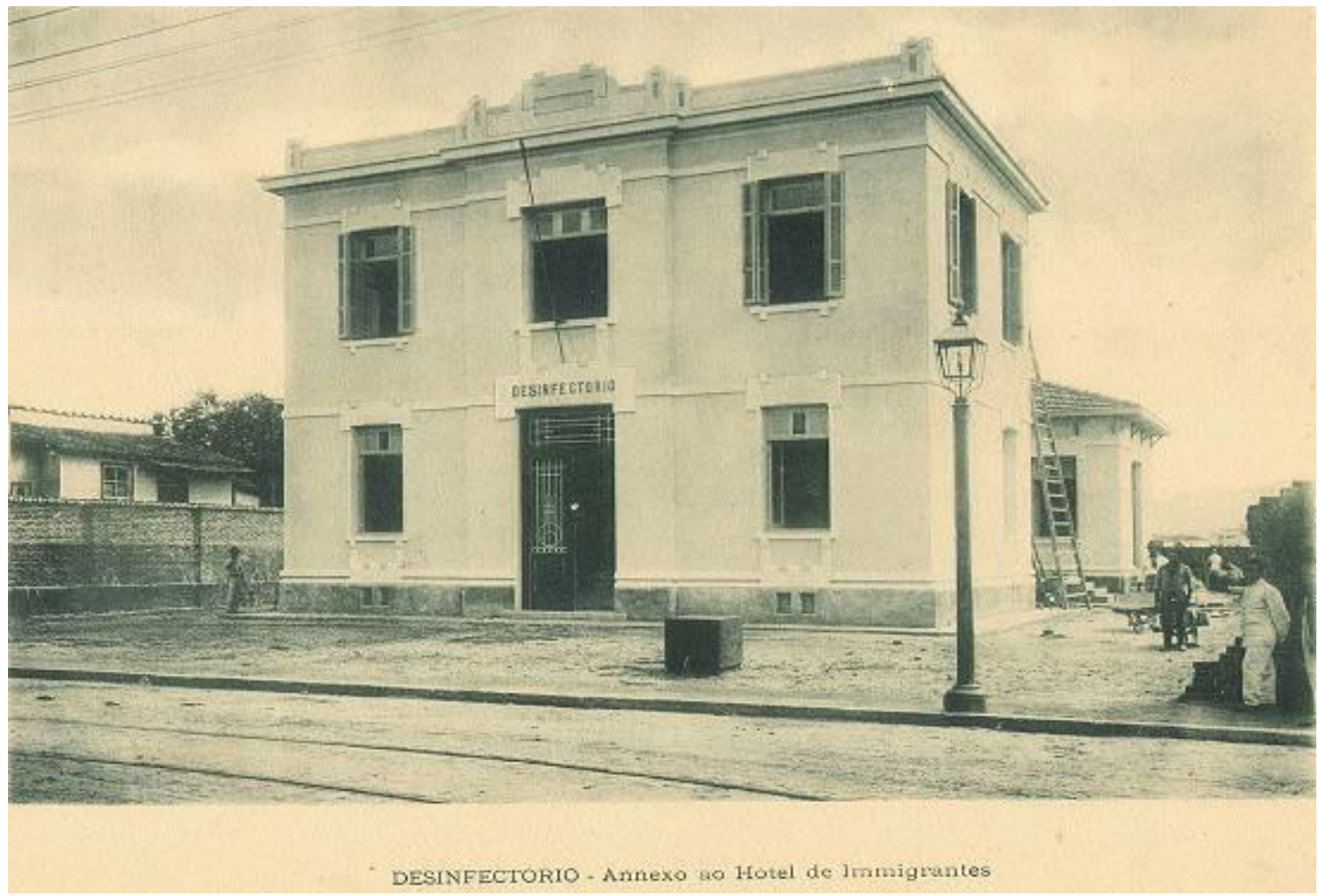

Imagem 7: Desinfectório. 1902. Fonte: Arquivo Público do Estado de São Paulo

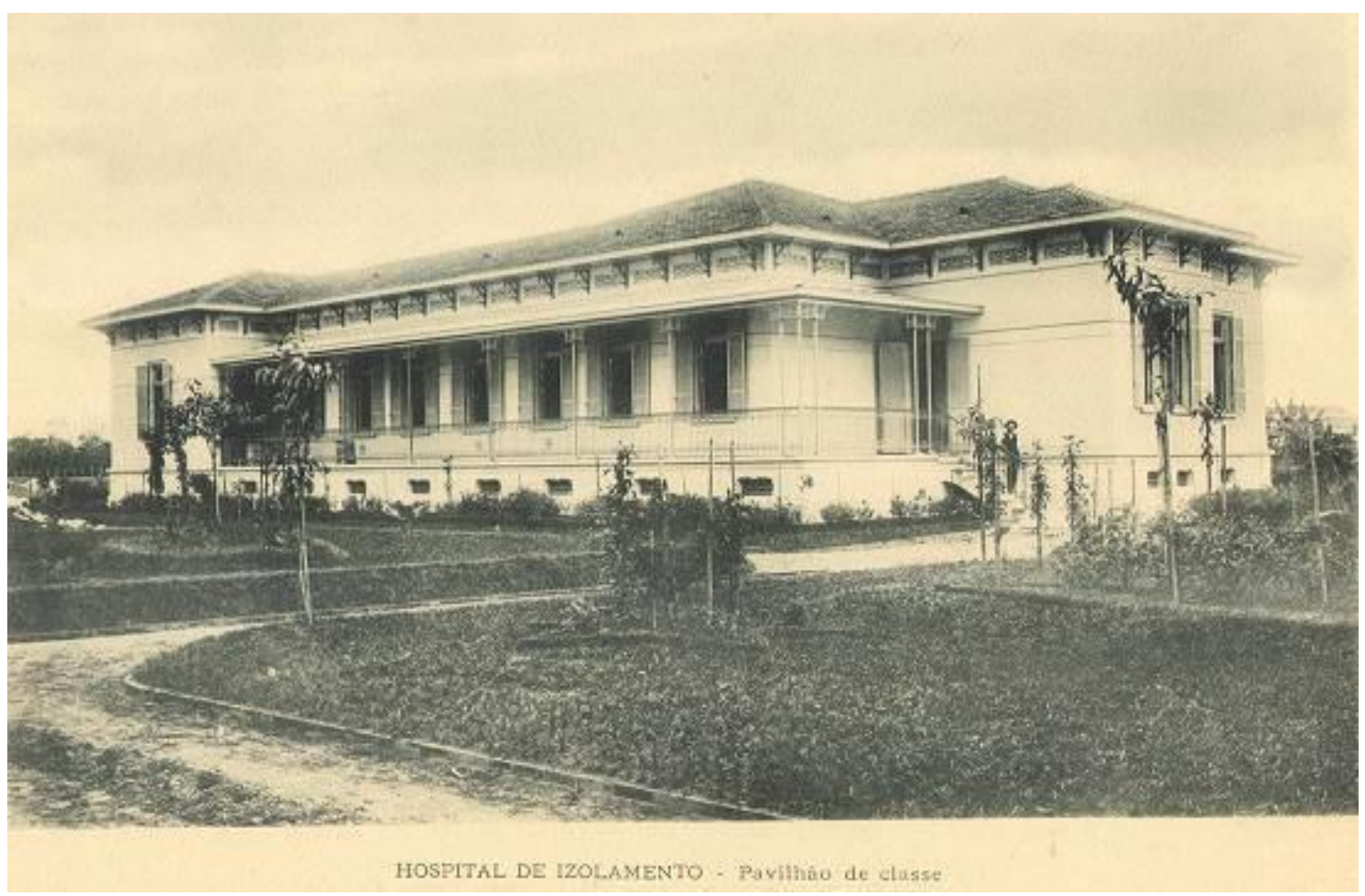

Imagem 8: Hospital de Isolamento. 1902. Fonte: Arquivo Público do Estado de São Paulo 


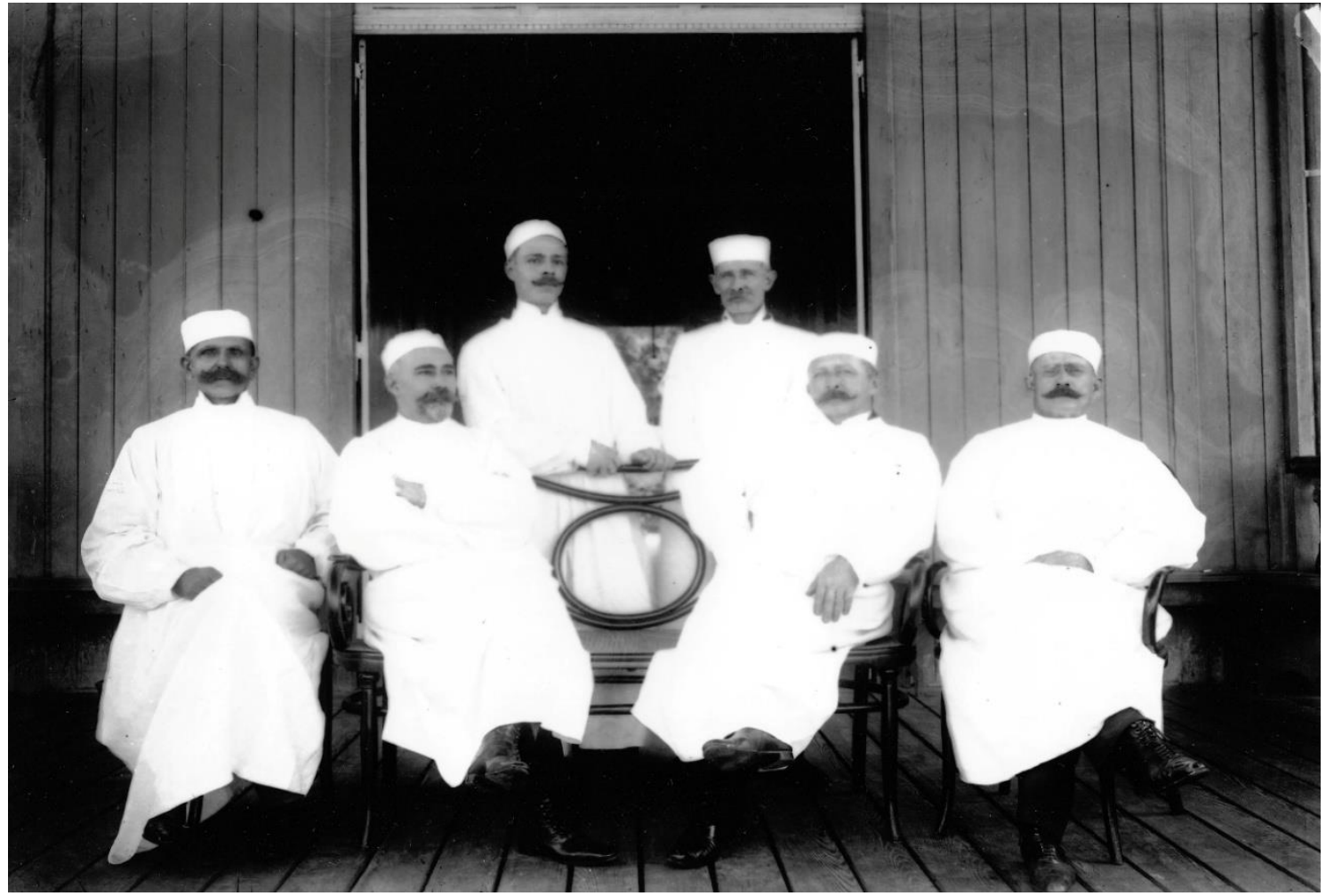

Imagem 9: Comissão Sanitária. 1899. Fonte: Arquivo Público do Estado de São Paulo

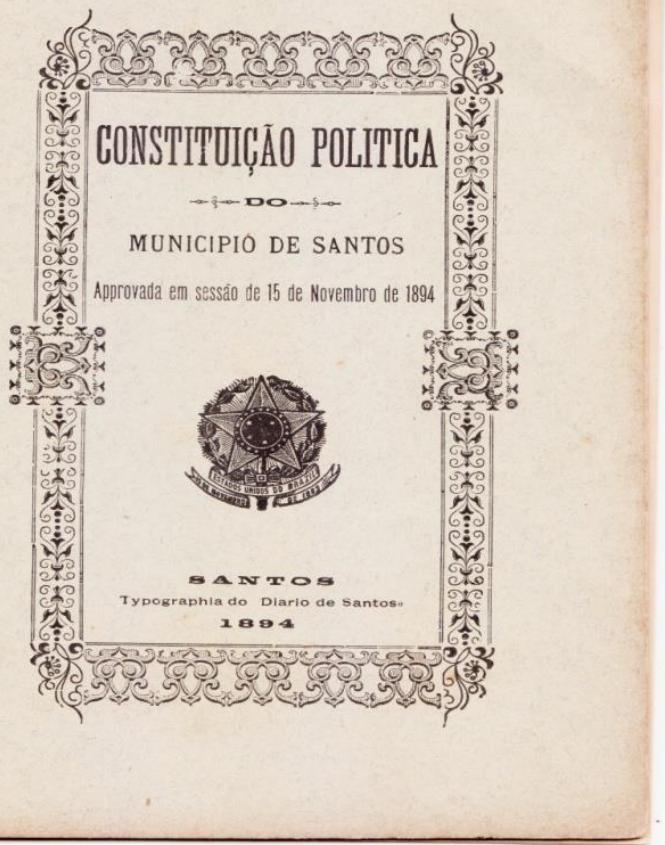

Imagem 10: Constituição Municipal de 1894. Fonte: Câmara Municipal de Santos 


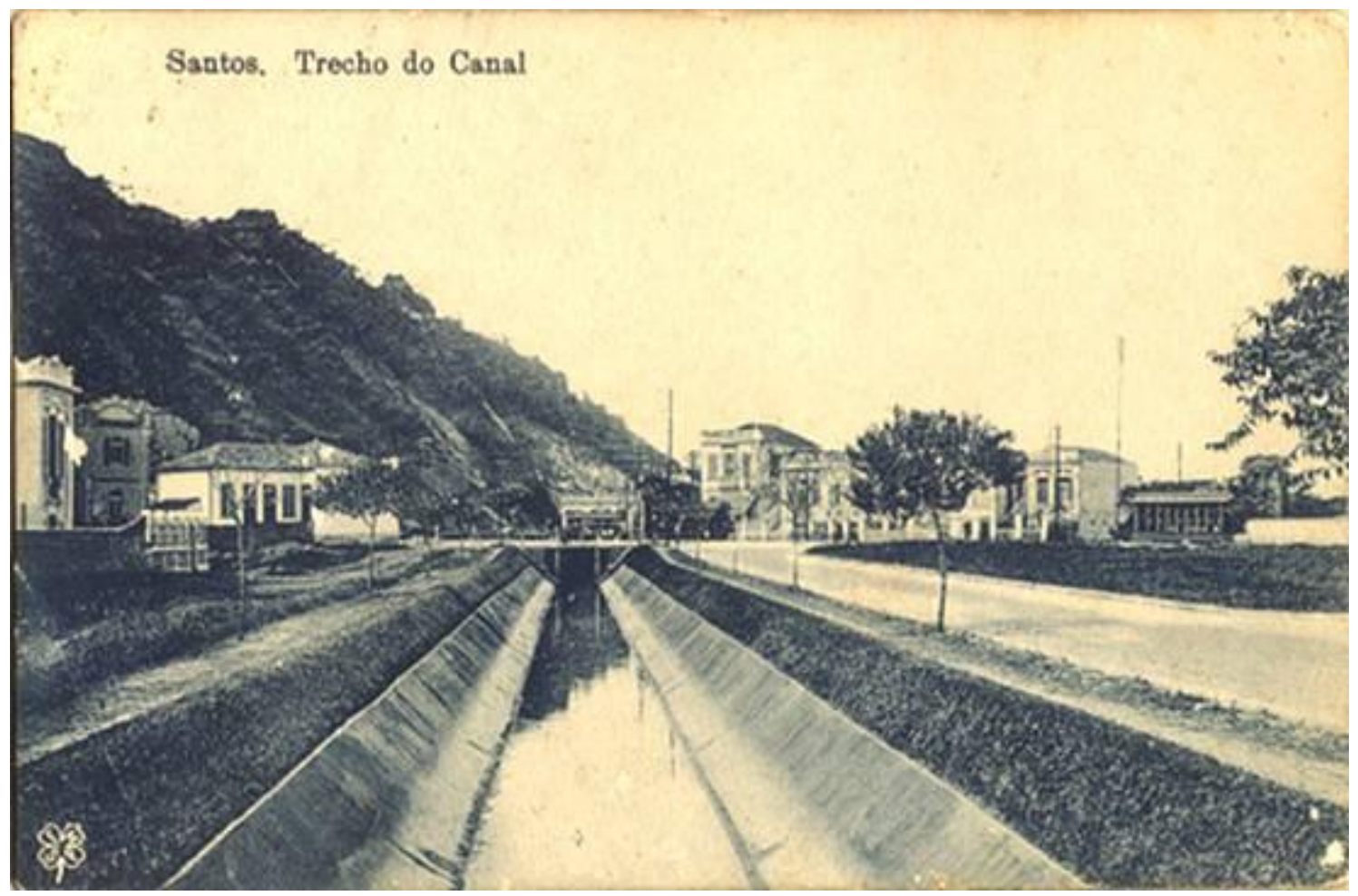

Imagem 11: Trecho de Canal de Saneamento. 1907. Fonte: Fundação de Arquivo e Memória de Santos.

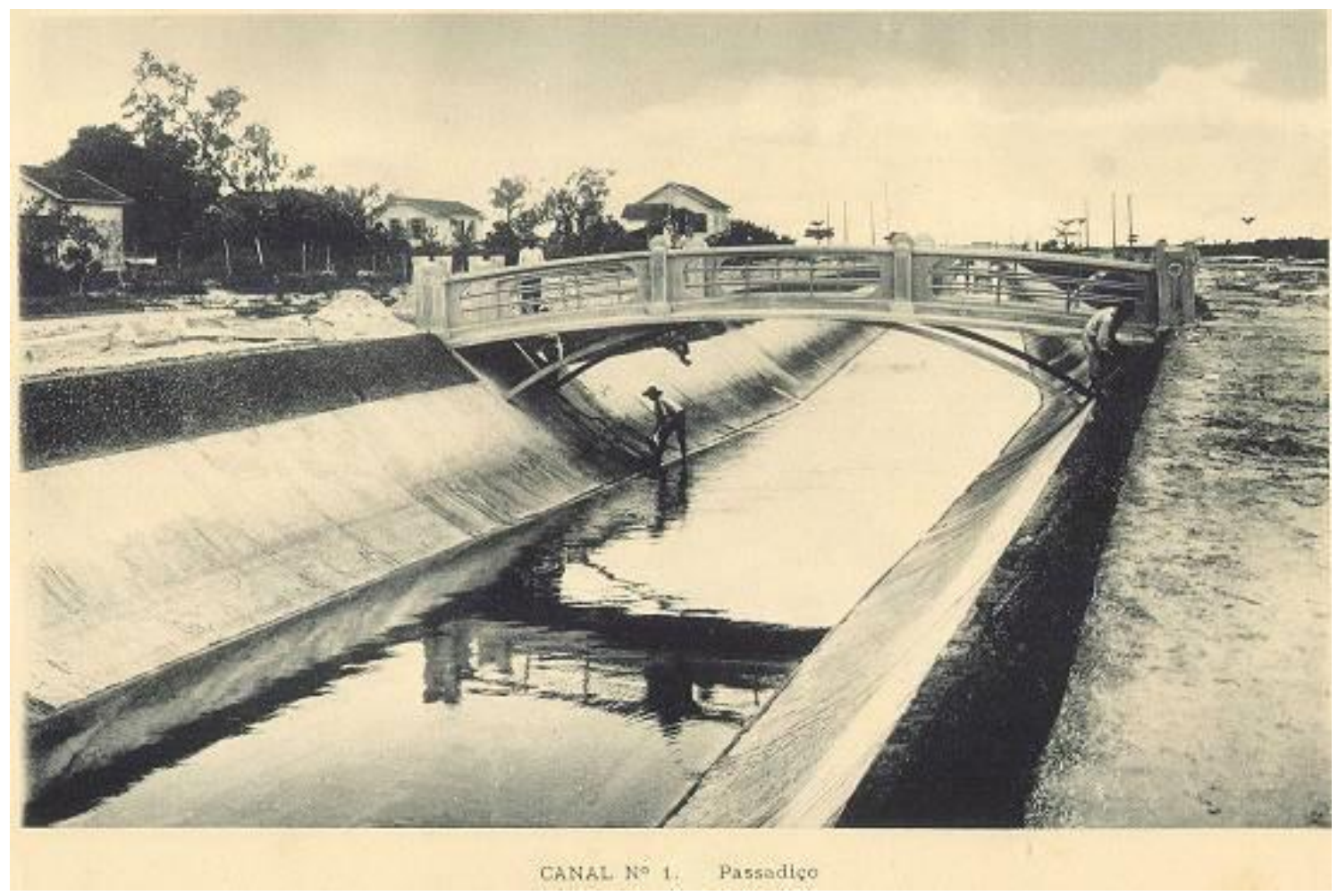

Imagem 12: Passadiço do Canal 1. 1907. Fonte: Fundação de Arquivo e Memória de Santos. 


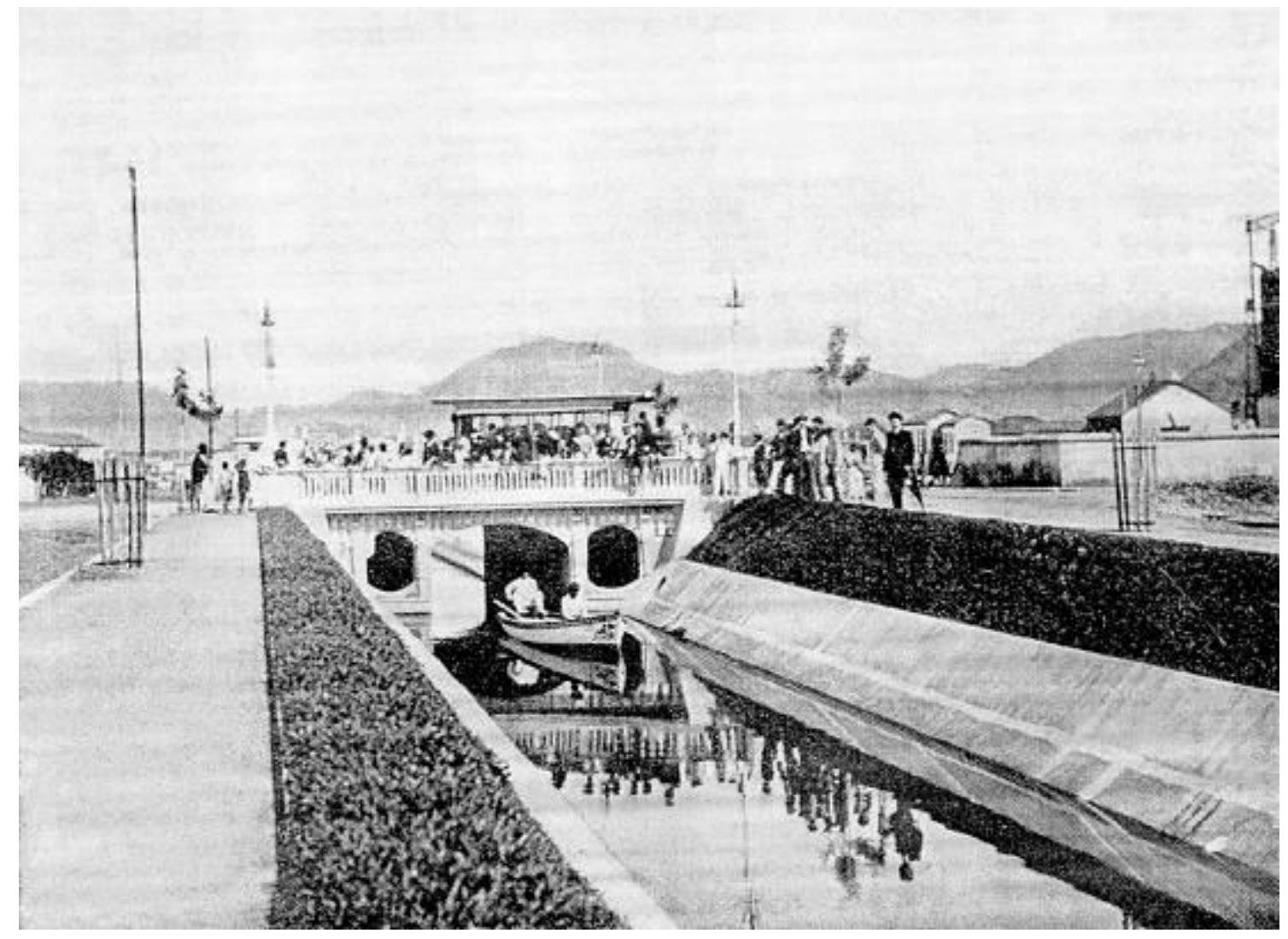

Imagem 13: Inauguração de Canal de Saneamento. 1907. Fonte: Obras Completas de Saturnino de Brito

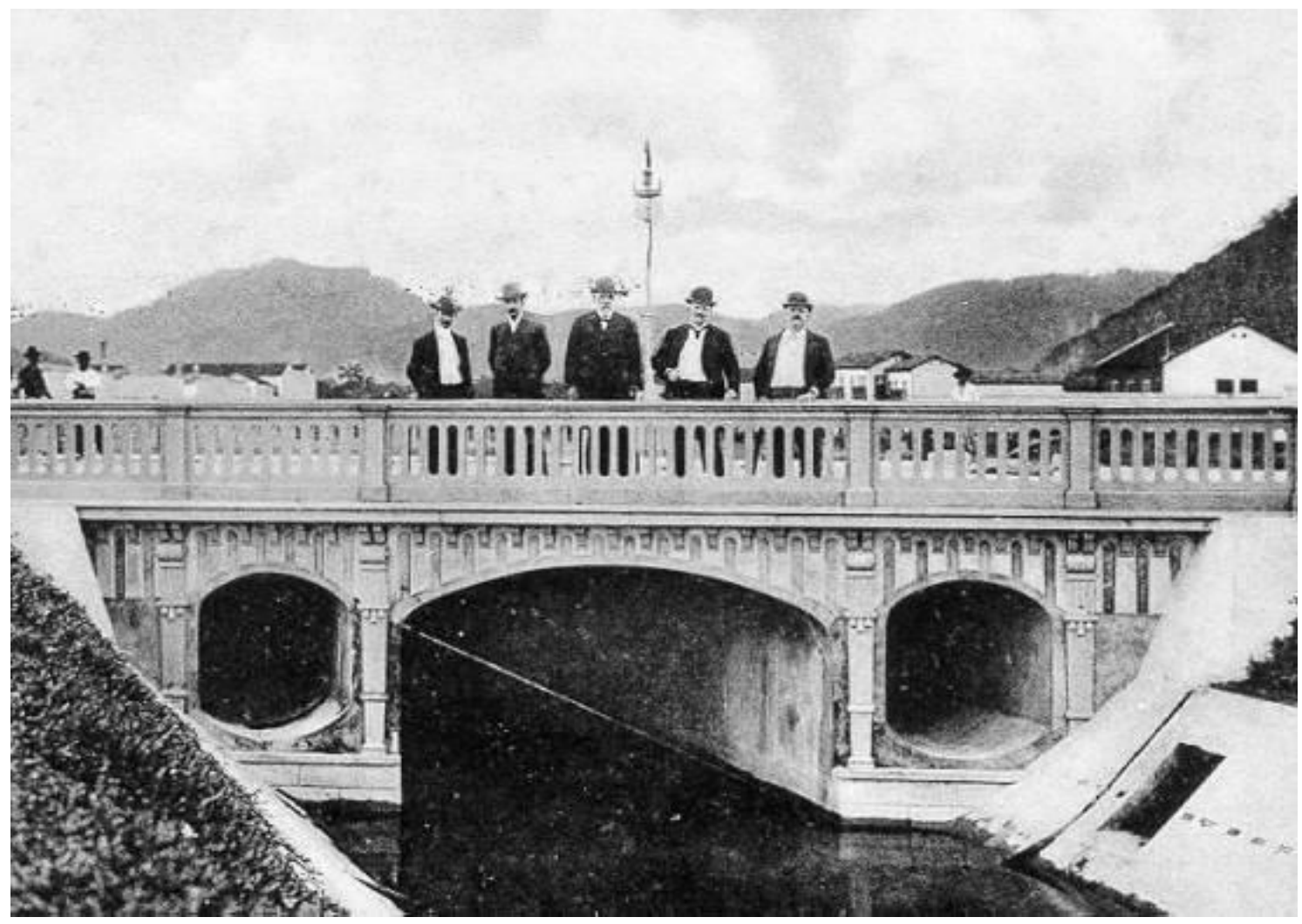

Imagem 14: Inauguração de Canal de Saneamento. 1907. Fonte: Obras Completas de Saturnino de Brito 


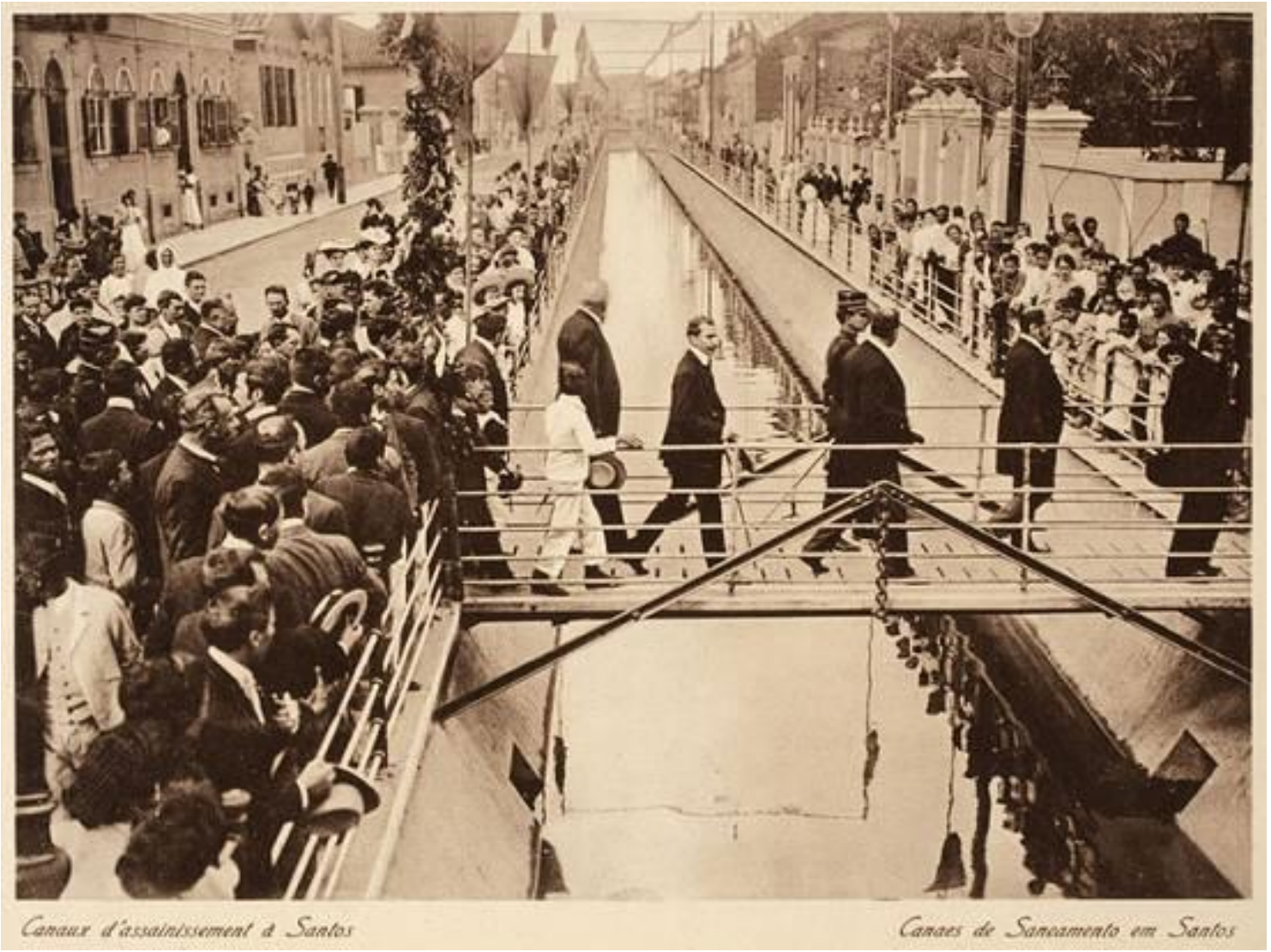

Imagem 15: Inauguração de Canal de Saneamento. 1907. Fonte: Arquivo Público do Estado de São Paulo

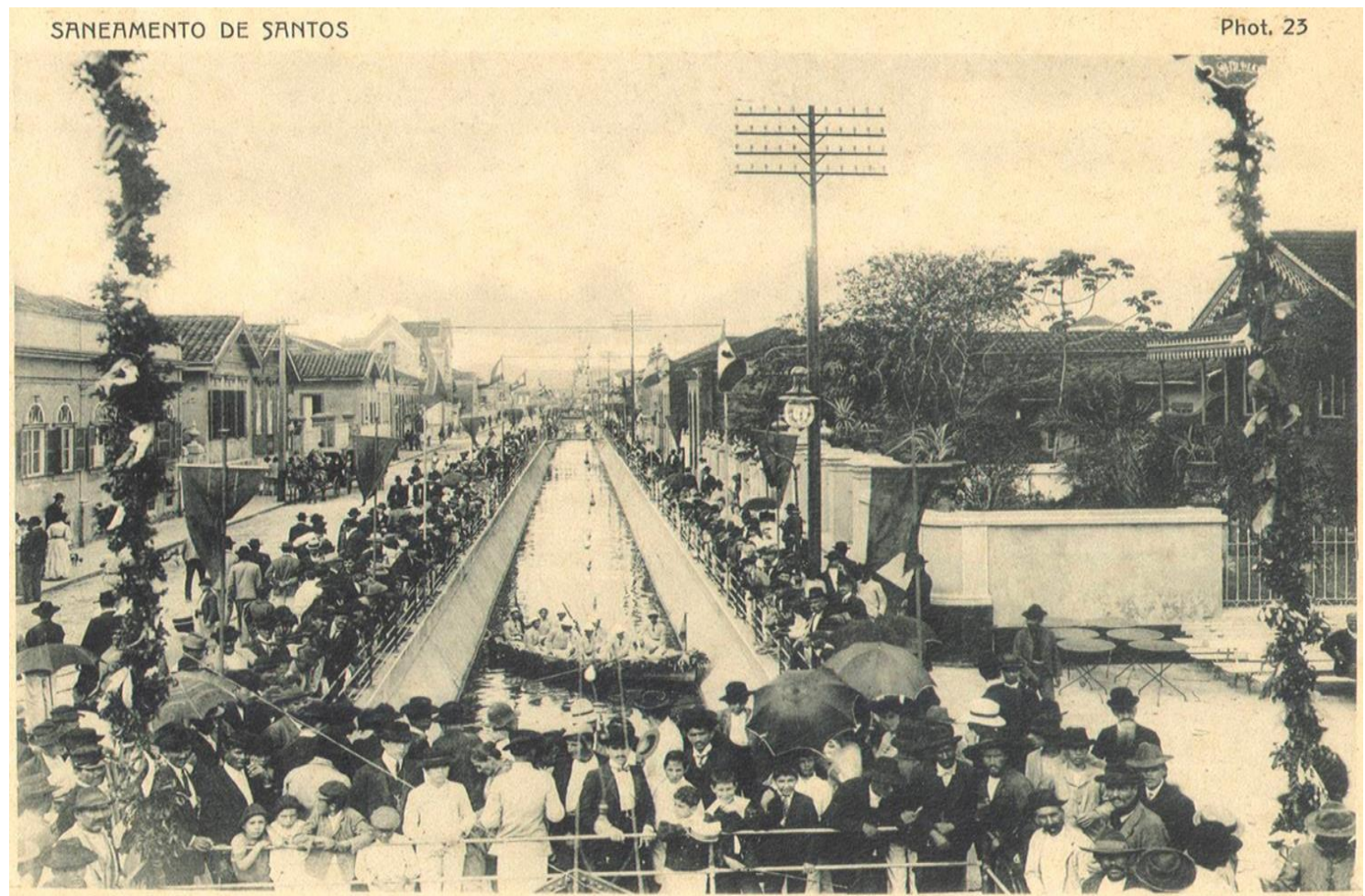

Inauguração dos primeiros trechos de canaes, pelo Presidente Dr. Jorge Tibiriçá .

Imagem 16: Inauguração de Canal de Saneamento. 1907. Fonte: Fundação Arquivo e Memória de Santos 


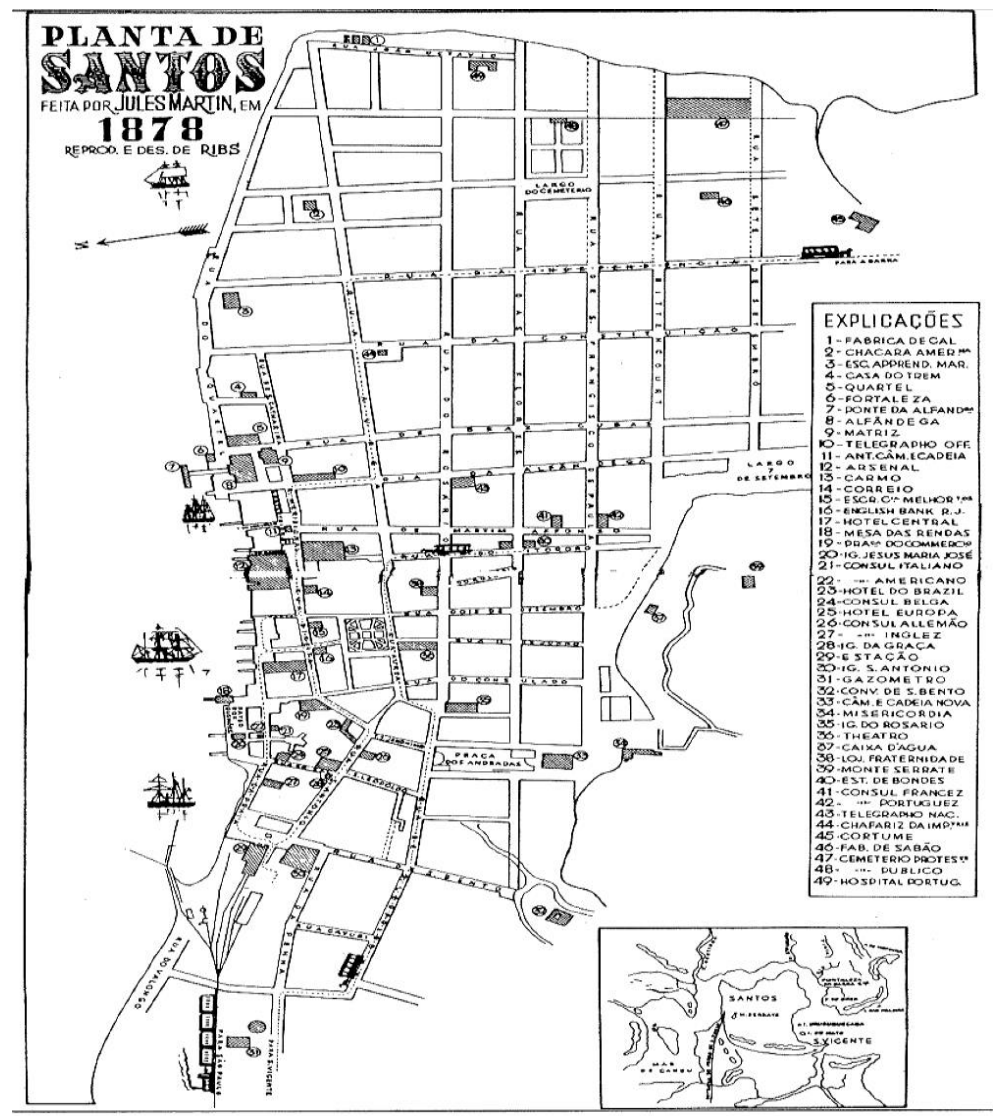

Imagem 17: Planta de Santos. 1878. Fonte: Arquivo Público do Estado de São Paulo

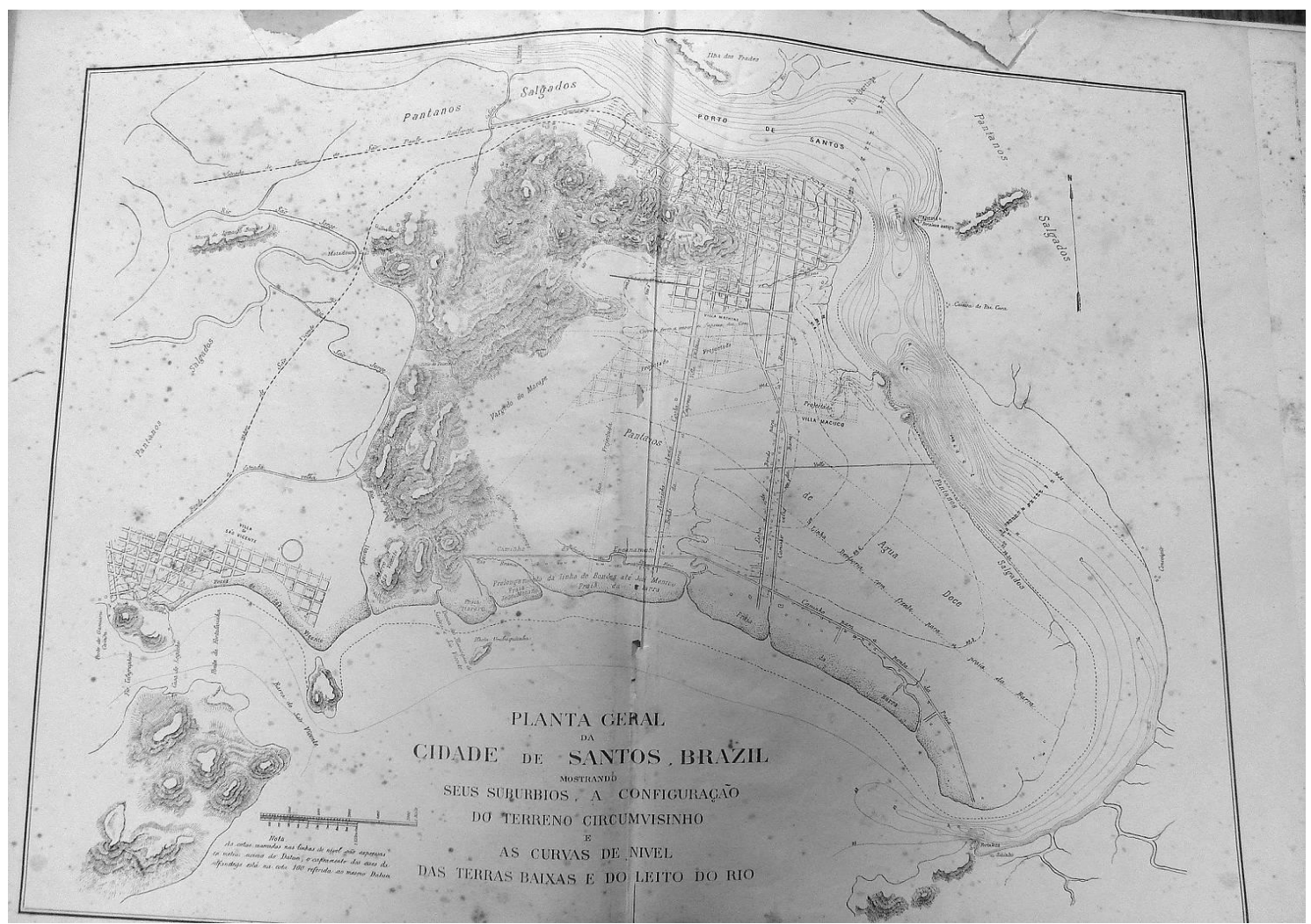

Imagem 18: Planta de Santos. 1895. Fonte: Arquivo Público do Estado de São Paulo 


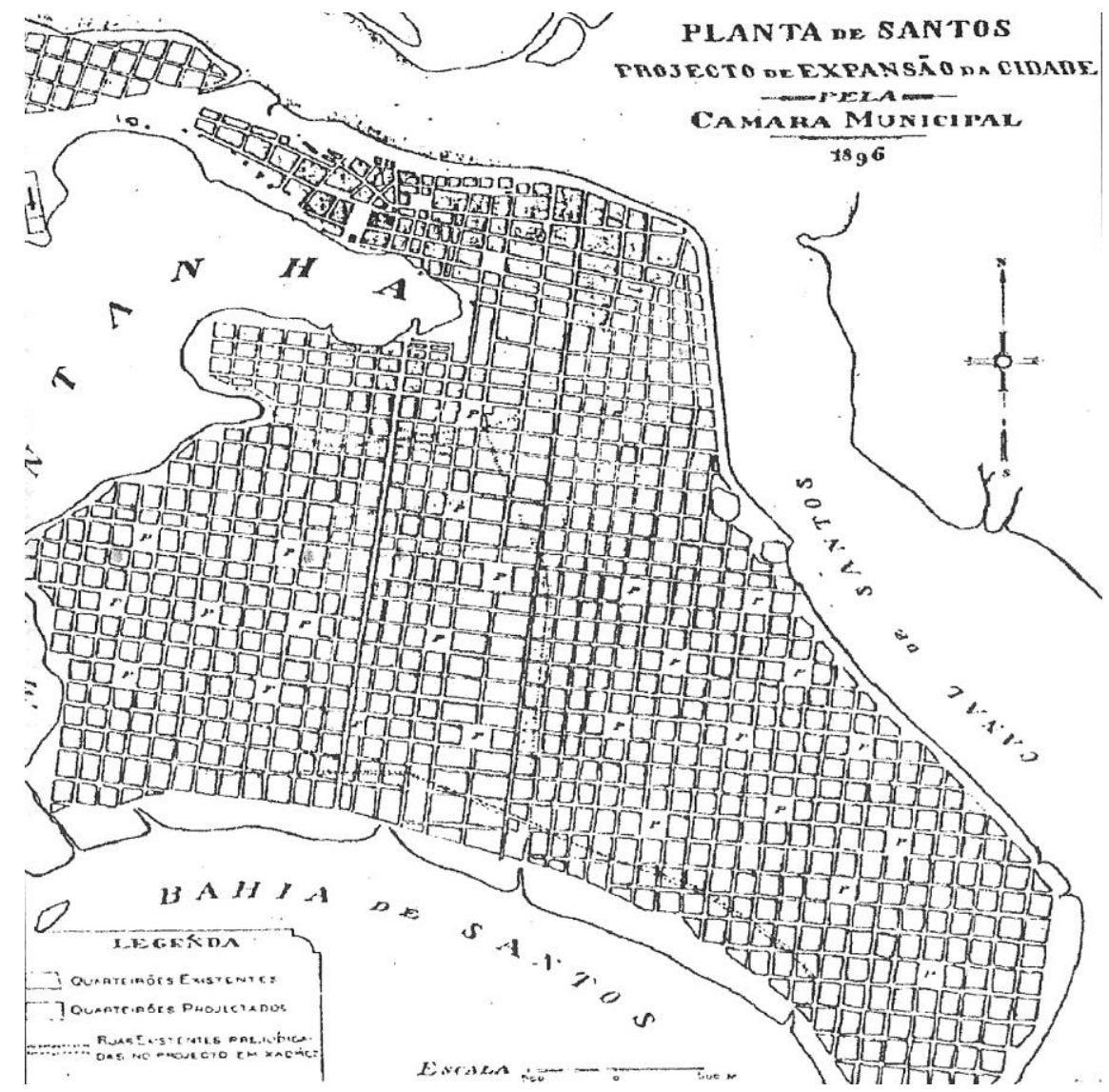

Imagem 19: Planta de Santos. 1896. Fonte: Câmara Municipal de Santos

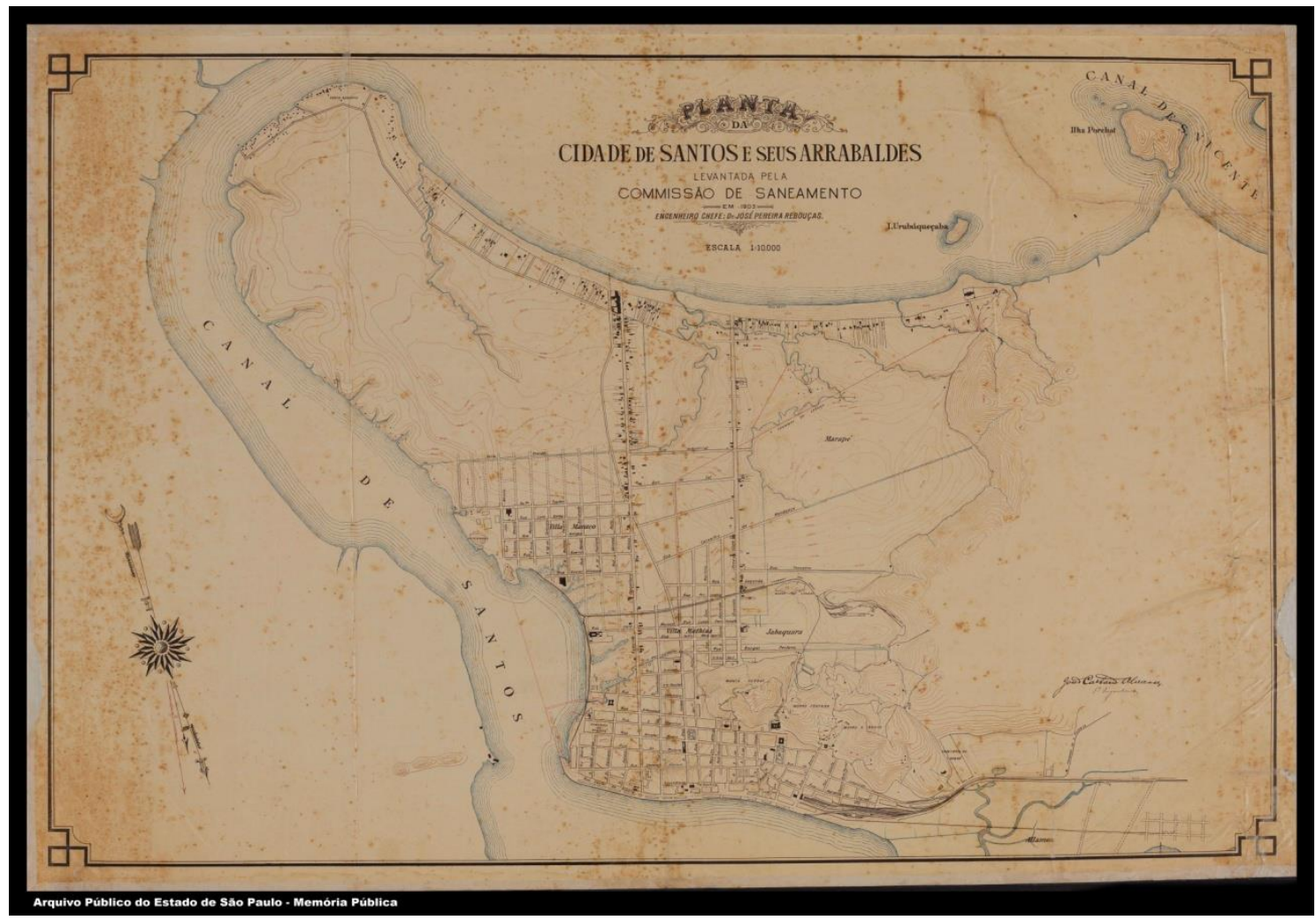

Imagem 20: Planta de Santos. 1903. Fonte: Arquivo Público do Estado de São Paulo 


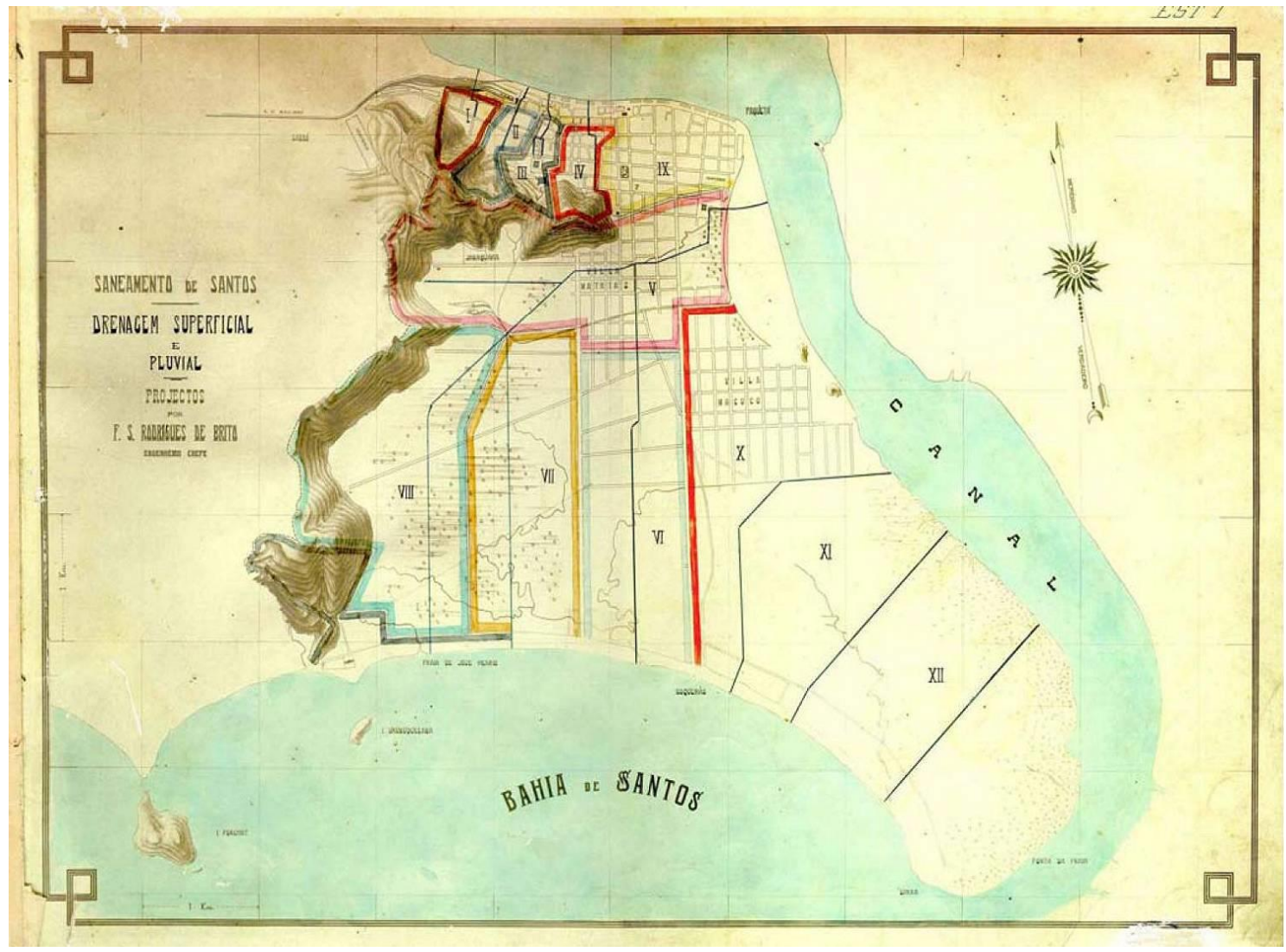

Imagem 21: Planta de Santos. 1905. Fonte: Arquivo Público do Estado de São Paulo

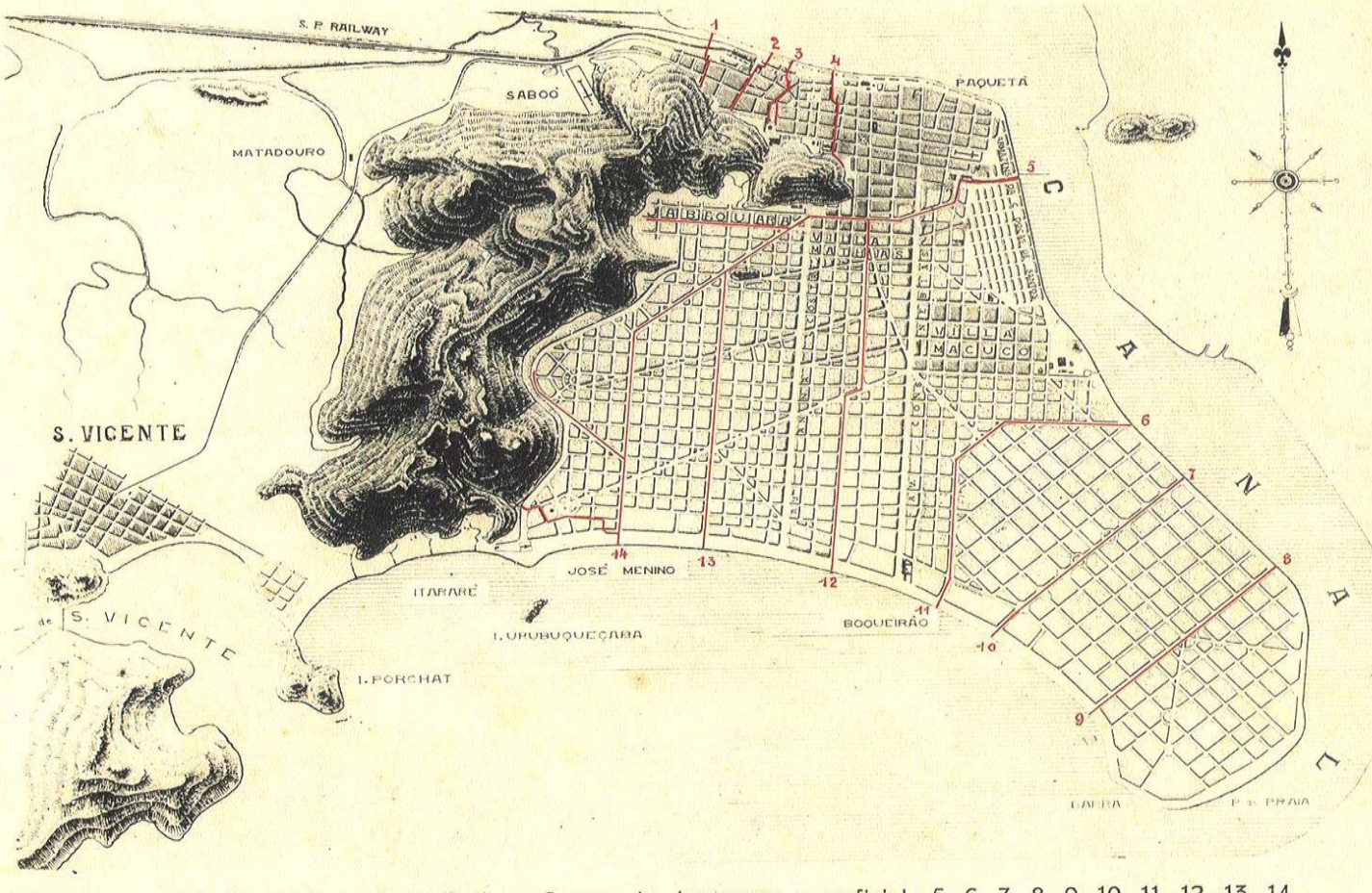

Galerias pluviaes: $1,2,3,4$ - Canaes de drenagem superficial: $5,6,7,8,9,10,11,12,13,14$

Imagem 22: Planta dos Canais de Drenagem. 1907. Fonte: Arquivo Público do Estado de São Paulo 


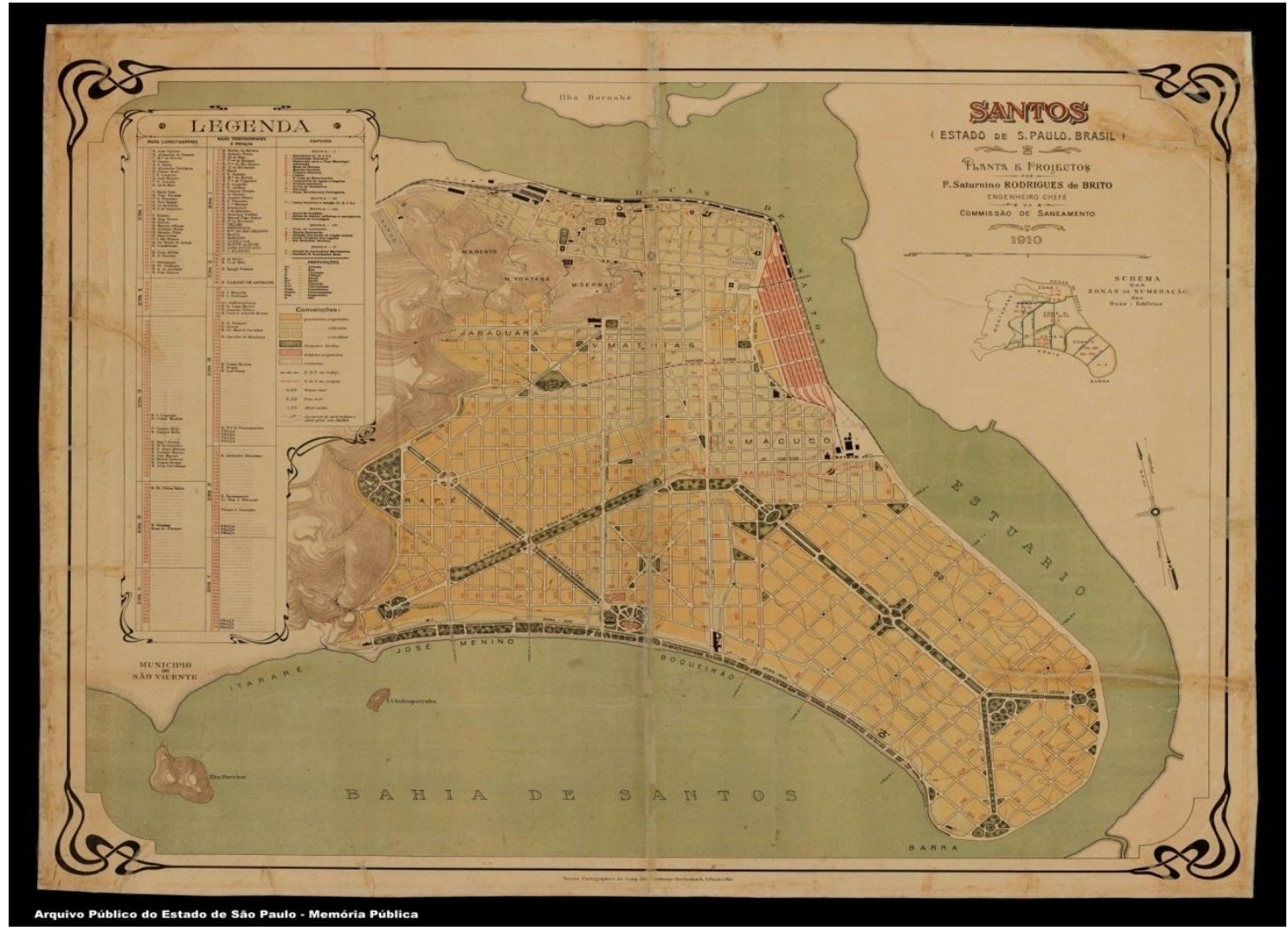

Imagem 23: Planta de Santos. 1910. Fonte: Arquivo Público do Estado de São Paulo

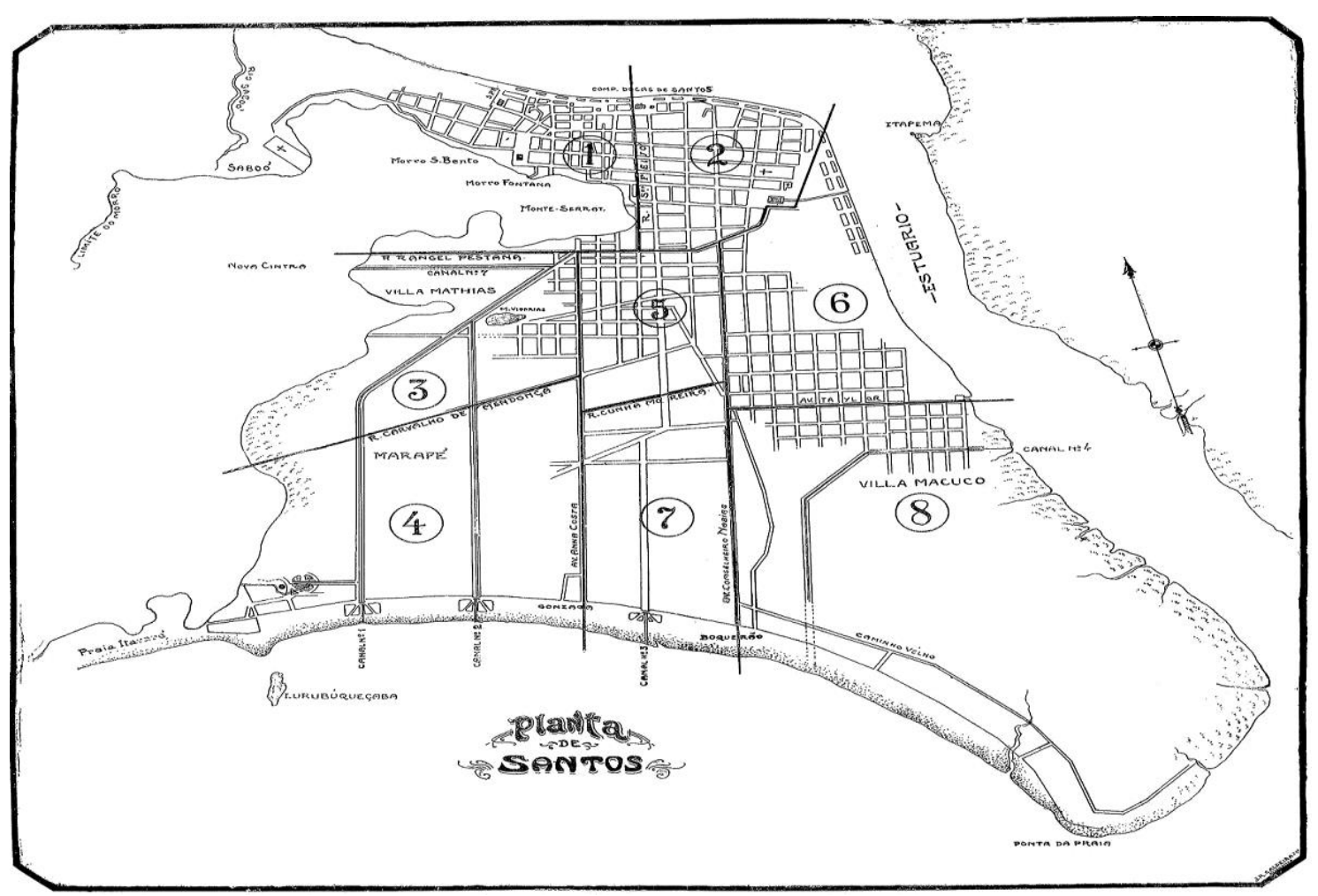

Imagem 24: Planta dos Distritos de Santos. 1913. Fonte: Arquivo Público do Estado de São Paulo 


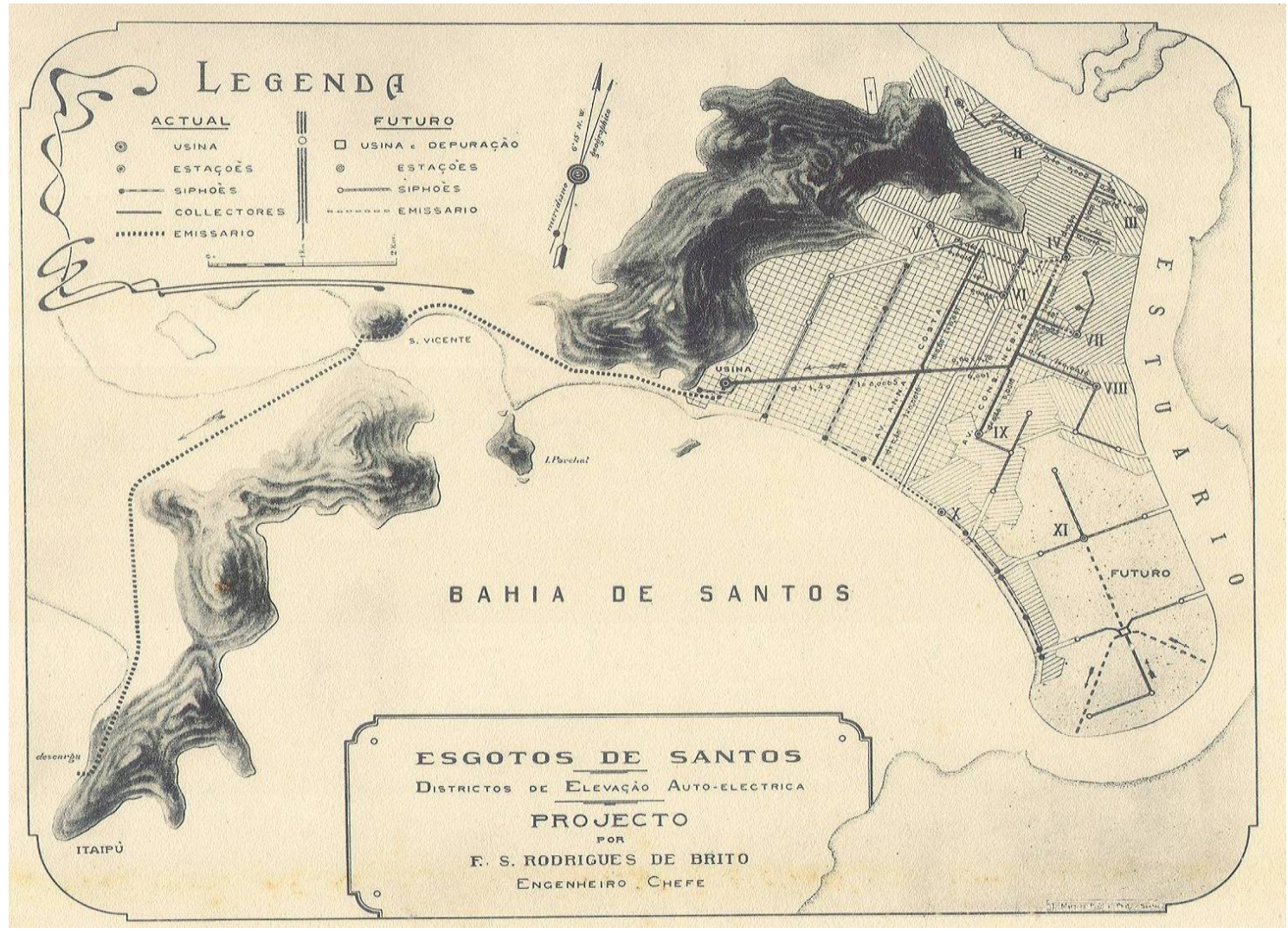

Imagem 25: Planta da Rede de Esgotos de Santos. 1913. Fonte: Arquivo Público do Estado de São Paulo

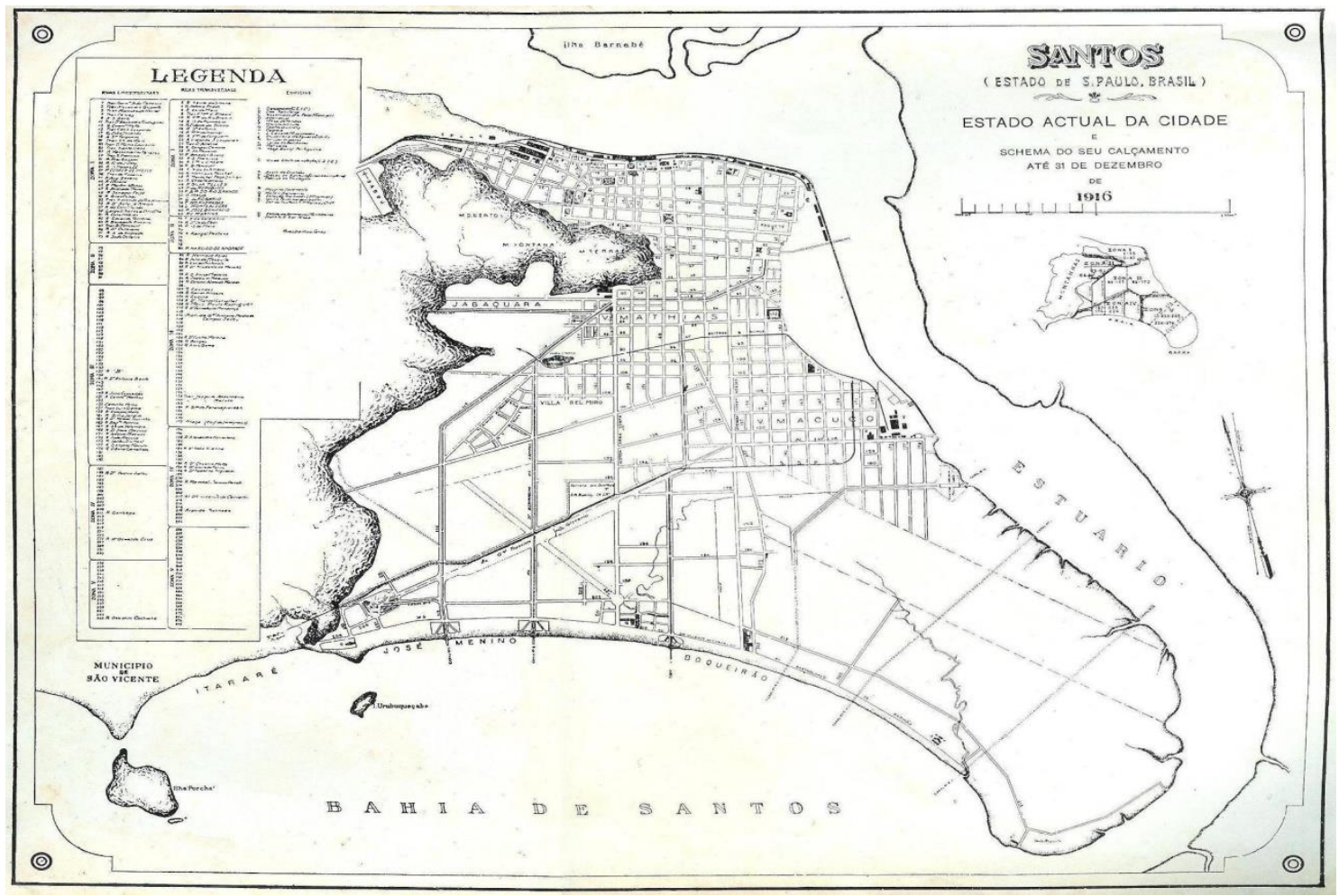

Imagem 26: Planta de Santos. 1916. Fonte: Arquivo Público do Estado de São Paulo 


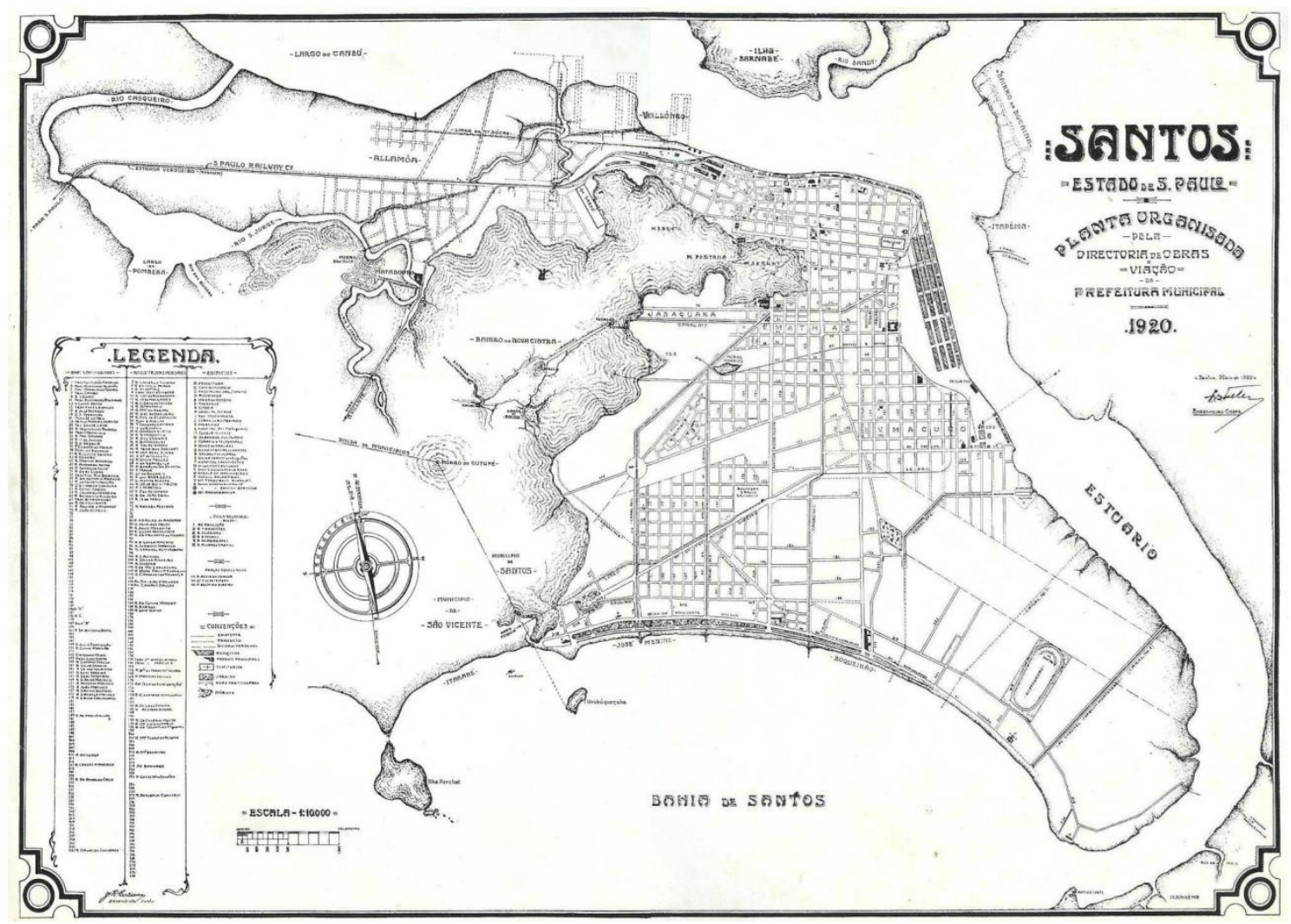

Imagem 27: Planta de Santos. 1920. Fonte: Arquivo Público do Estado de São Paulo 
Capítulo 2: Da civilização idealizada ao trabalhador indesejado: demografia, nacionalidade e formação da classe trabalhadora santista 
"Aos raios inflamados do sol, naquela manhã de juventude, o campo estava tomado por aquele rumor. Os homens brotavam, era um exército coberto de carvão, vingador, que germinava lentamente da terra, para crescer nas colheitas do século seguinte. A germinação daquele exército logo faria explodir a terra." (Émile Zola, Germinal, 1885)

"Aqui, ali, por toda a parte, encontravam-se trabalhadores, uns ao sol, outros debaixo de pequenas barracas feitas de lona ou de folhas de palmeira. (...) Aqueles homens gotejantes de suor, bêbados de calor, desvairados de insolação, a quebrarem, a torturarem a pedra, pareciam um punhado de demônios revoltados na sua impotência contra o impassivel gigante que os contemplava com desprezo, imperturbável a todos os golpes e todos os tiros que desfechavam no dorso, deixando sem um gemido que the abrissem as entranhas de granito."

(Aluísio Azevedo, O Cortiço, 1890) 
Os limites físicos da cidade de Santos só foram alterados em fins do século XIX com as novas características que ela foi gradativamente assumindo e com o conseqüente crescimento populacional.

A população santista cresceu vertiginosamente no período, resultado tanto dos fluxos migratórios quanto do avanço de suas funções portuárias e das medidas de saneamento da cidade.

\begin{tabular}{|l|l|l|l|l|}
\hline Ano do Censo & Homens & Mulheres & Escravos & Total \\
\hline 1872 & 4.108 & 3.447 & 1.606 & 9.151 \\
\hline 1886 & - & - & - & 15.505 \\
\hline 1890 & 7.150 & 5.862 & - & 13.012 \\
\hline 1900 & 27.688 & 22.701 & - & 50.389 \\
\hline 1913 & 49.482 & 39.485 & - & 88.967 \\
\hline
\end{tabular}

(População de Santos (1872 - 1913). Fonte: Recenseamento da Cidade e Município de Santos, 1913.)

Mesmo em períodos de altíssima mortalidade em função das epidemias exemplificado pelos índices de mortalidade superiores aos de natalidade da década de 1890 a população crescia (ÁLVARO, 1919). Os números impressionam: de 9.151 habitantes em 1872, a cidade chegou a mais de 50 mil em 1900 e 88.967 em 1913 (ver tabela acima).

Em período de acelerado crescimento populacional, as epidemias se apresentavam como contraponto. No início do século XX, as taxas de mortalidade chegaram a atingir 100 pessoas por mil habitantes (GAMBETA, 1988, p. 25).

O crescimento da população por si só, embora significativo, não explica a complexidade das relações sociais que se estabeleceram no espaço urbano santista no período citado. Importante identificar e entender quem eram os habitantes da cidade, de onde vinham, como se relacionavam e como se configuravam os distanciamentos e as aproximações sociais entre eles.

Nosso estudo focaliza basicamente a vida de trabalhadores e pobres em geral procurando inseri-los, através de suas múltiplas experiências - e tomando emprestada a noção de experiência em Thompson (1981 e 2011) - nessa cidade em intenso processo de transformação. Entre essas experiências, a prática do inicialmente elitizado futebol e a apropriação do esporte pela classe trabalhadora local. 


\subsection{O Censo de 1913 e a população santista nos primeiros anos do século XX}

Em 1913, a prefeitura municipal realizou um minucioso recenseamento da população de Santos, apresentando uma estatística relativamente detalhada de seus habitantes e de suas especificidades, como origem e profissões. Entre os cerca de 90 mil habitantes, 56\% eram homens e $44 \%$ eram mulheres. O percentual de brancos saltou de 55,3\% em 1872 para 86,8\% em 1913. Os imigrantes, quase todos provenientes da Europa, correspondiam a $42,5 \%$ da população total. Segundo Maria Lucia Caira Gitahy, "para cada 100 habitantes santistas em 1913, 25 eram portugueses, 9 eram espanhóis e 3 eram italianos, além da presença relativamente expressiva de turcos, britânicos, japoneses, austro-húngaros e argentinos" (1992, p. 42). O contingente português era, de longe, o mais numeroso e ocupava-se na construção civil, nas obras do porto, nos armazéns de café, no comércio, nas docas e na estiva (FRUTUOSO, 1989, p. 47)

A população economicamente ativa era de 37.179 pessoas, sendo $86 \%$ de homens e $14 \%$ de mulheres. Comércio e atividades correlatas (bancos, seguros e mutualismo) eram responsáveis pelo maior número de empregados $(23,91 \%)$, seguidos do setor caracterizado como "meios de comunicação/transportes", com 22,73\%. Desse montante, mais de $90 \%$ eram operários e trabalhadores braçais que operavam em transportes marítimos e terrestres, ou seja, vinculados em sua grande maioria ao porto (doqueiros, ensacadores, carroceiros e estivadores). Assim, como aponta Alcindo Gonçalves (1995), quase 23\% da população economicamente ativa de Santos em 1913 estava empregada exclusivamente em serviços e atividades portuárias (ver imagens 1 e 2, p. 78). Em seguida, apareciam as chamadas "profissões independentes" (capitalistas, proprietários e pequenas profissões), em um total de 3.596 pessoas, ou pouco menos de $10 \%$ da população. As denominadas atividades primária e secundária eram pouco expressivas: 7,8\% na "agricultura e anexos" e 1.456 (3,8\%) na "indústria fabril e similares". No ramo têxtil, a principal firma empregadora era a Companhia Santista de Tecelagem, fundada em 1902. Em 1912, um ano antes da divulgação do recenseamento, mantinha em seu quadro de funcionários 480 operários, em sua maioria mulheres que trabalhavam como costureiras de sacaria. Em relação aos operários da construção civil e outros ofícios, o censo menciona apenas os trabalhadores das pedreiras (ver imagens 11 e 12, p. 83), totalizando pouco menos de 700 trabalhadores. No entanto, um documento do sindicato da categoria, publicado em 1909, indica a quantidade de cerca de 1.800 trabalhadores no setor (GITAHY, 1992, p. 94). 
Embora um tanto genérico no que diz respeito à caracterização das outras atividades profissionais existentes na cidade, "o censo nos indica que as atividades vinculadas ao transporte portuário, à infra-estrutura urbana e à construção civil eram as mais representativas do movimento operário local" (SILVA, 2003, p. 223). Se considerarmos apenas os trabalhadores de transportes e indústria fabril, teremos $24 \%$ da população economicamente ativa como um contingente de trabalhadores que poderiam ser incluídos no perfil do operariado que, genericamente, teve algum envolvimento em greves, movimentos de reivindicação e sindicatos. Se incluirmos, entretanto, operários, jornaleiros, trabalhadores braçais do setor de "comércio e atividades correlatas" e administração pública que, pela sua participação nas obras de infra-estrutura urbana, eventualmente participaram de movimentos reivindicatórios, esse índice sobe para aproximadamente 35\%. Esse percentual pode ser ainda maior caso forem considerados os trabalhadores da construção civil como profissionais "independentes", o que é bem possível levando em conta o caráter intermitente de suas atividades.

Em todas as atividades profissionais citadas anteriormente, assim como no processo de formação da classe operária local, a presença de imigrantes europeus foi expressiva. No início do século XX, a maior parte dos trabalhadores da Companhia Docas de Santos era, por exemplo, composta por estrangeiros (HONORATO, 1996).

A crescente urbanização de Santos, que se consolidou como ponto de trânsito de produtos de exportação e importação e como dinâmico centro econômico e político, provocou transformações sociais em um curto espaço de tempo e em ritmo acelerado. A cidade que gravitava em torno do porto tornava-se um imã atraindo cada vez mais pessoas e gerando uma crise que se manifestava no seu aspecto demográfico. O número e perfil da população foram alterados significativamente por um processo de intensa imigração européia.

Essa heterogeneidade habitava os espaços públicos e privados da cidade e dava a ambos uma configuração peculiar, criando novos locais de convivência. Ao mesmo tempo em que espaços eram consolidados, novos contatos eram feitos, experiências criadas e grupos forjados, novos modos de vida passavam a existir.

Essa população encontrava-se majoritariamente amontoada em moradias precárias, em becos, cortiços, vielas, praticamente sem água, esgoto e iluminação, enfim, sem condições sanitárias mínimas (LANNA, 1996 e GAMBETA, 1984).

\subsection{Imigração européia e o mundo do trabalho: a vida cotidiana da população pobre na cidade de Santos}


Em Santos, o contingente imigrante, em particular de portugueses e espanhóis, foi incorporado em serviços estratégicos ao funcionamento básico da economia agroexportadora nos armazéns de café e docas, onde exerceram atividades de doqueiros, estivadores, ensacadores e carroceiros (ANDRADE, 1989). Sobre o cotidiano dos trabalhadores vinculados às atividades portuárias, Maria Izilda Santos de Matos (2004), nos oferece importante contribuição:

\footnotetext{
"As sacas de café, ao chegarem em Santos, eram descarregadas dos vagões dos trens e colocadas nos depósitos alinhados ao longo da via férrea. Carroças estacionavam junto às portas desses depósitos e retiravam a mercadoria. Iniciava-se então o transporte pelas ruas estreitas da cidade até os armazéns particulares e o porto. Havia firmas organizadas, mas geralmente os carroceiros, quase todos imigrantes, dividiam entre si o transporte de café pela cidade. $\mathrm{O}$ trabalho girava em torno da safra, quando o ritmo de trabalho era intensificado. O número de carroças transitando crescia em proporção direta ao aumento da quantidade de café exportado. Pelas ruas homens corriam ao lado das carroças puxadas a burro, sob calor sufocante. (...) No porto, o embarque era feito carregando-se os sacos nas costas, e como num formigueiro humano os trabalhadores subiam e desciam com sacos nos ombros as pranchas do cais para os convés dos navios, ou de um navio para outro. Carroceiros e carreteiros realizavam também inúmeras tarefas ligadas à circulação de alimentos e de mercadorias em geral e no suporte à construção civil. Todavia, os ganhos eram incertos, pois se em alguns dias arranjavam fregueses, em outros ficavam parados. Durante a safra o trabalho era intenso, mas em outros momentos do ano os ganhos eram eventuais." (MATOS, 2004, p. 14)
}

Em Santos, a construção do porto e o saneamento da cidade foram obras interligadas no quadro de transformação urbana e "fizeram parte de um processo através do qual se reorganizaram o trabalho e a própria face da cidade" (GITAHY, 1992, p. 29).

A atração exercida pelo porto provocava concentração de significativo contingente de trabalhadores e, como conseqüência, ampliavam-se o subemprego e o emprego flutuante de uma população marcadamente estrangeira que garantia sua sobrevivência com ocupações casuais. O salário do trabalhador do porto - considerando as atividades portuárias como hegemônicas nas relações produtivas da cidade - flutuava conforme a sazonalidade, o que 
criava grande impacto nos orçamentos familiares, nos padrões de moradia e nas formas cotidianas de subsistência.

Curioso perceber, ao analisar o impacto da presença estrangeira no universo laboral, a desconstrução de certos mitos sobre o papel "civilizador" do imigrante europeu no início do século. O caráter civilizatório e o mito do "branqueamento" da população davam rapidamente lugar à visão do imigrante europeu, mais especificamente do imigrante europeu pertencente à classe trabalhadora, como alguém perigoso. Em pouco tempo, a inspiradora Europa idealizada pelas classes dominantes iria se chocar com a visão dos europeus, imigrantes e trabalhadores - pobres, em sua maioria -, que por aqui chegavam aos milhares. O modelo do que se entendia por "civilização" daria lugar à concepção do estrangeiro "agitador" e indesejado.

O discurso de ordem social, consubstanciado através do já citado Código de Posturas de 1897, outorgava às autoridades policiais o poder de vigiar e restringir os espaços de circulação da população trabalhadora e pobre da cidade. Incorporando parte dos dispositivos do Código Sanitário, buscava-se normatizar todas as instâncias da vida social e econômica, dos costumes públicos ao uso do idioma estrangeiro, da higiene ao horário de funcionamento dos estabelecimentos, tendo por objetivo fundamental "banir da cidade tudo o que não fosse contemplado pelo projeto de modernidade - uma cidade limpa, elegante, ampla - que se pretendia instaurar" (CÁNOVAS, 2017, p. 78). Em nome da "manutenção da ordem pública", estabelecia-se uma teia de controle sobre as chamadas "classes perigosas". Era preciso saber onde viviam, de onde vinham e quanto tempo permaneceriam na cidade.

O artigo 110 do Código, por exemplo, obrigava que:

\footnotetext{
"Os hotéis, hospedarias, casas de pensão e de alugar quartos, terão um livro que será numerado e rubricado pelo Intendente Municipal, no qual os proprietários inscreverão o nome, a naturalidade, a procedência e a idade provável das pessoas recebidas nos locais. Este livro será diariamente apresentado à autoridade policial. O descumprimento será penalizado por multa de $50 \$ 000$ e de $100 \$ 000$ em caso de reincidência."
}

Por mais que se possa problematizar o efetivo cumprimento do dispositivo legal, é preciso levar em conta que hotéis, hospedarias, pensões e casas com quartos de aluguel serviam invariavelmente de moradia para a população pobre que gravitava em torno da região central da cidade em busca de trabalhos muitas vezes ocasionais. O mesmo raciocínio pode ser aplicado aos artigos 147 e 148, que dispunham detalhadamente sobre de que forma poderiam 
funcionar as tavernas e que afirmavam, por exemplo, que "os donos de tavernas que venderem bebidas alcoólicas a pessoas já embriagadas sofrerão multa de dez mil réis".

As atribuições do chefe de polícia, presentes no artigo 22 do Código de 1897, trazem interessantes informações nesse sentido. Entre as mais de vinte prescrições à sua atividade, a maior parte versa sobre questões de ordem moral. Entre as competências especificas da função estavam:

\footnotetext{
"Fazer respeitar, por todos os meios legais, os direitos individuais, e manter a ordem pública. (...) Empregar a força armada policial nas diligências necessárias à manutenção da ordem e sossego da população. (...) Processar e julgar os termos de bem-viver e segurança. (...) Prender os vadios, mendigos, bêbados por hábito e vagabundos, para sujeitá-los aos devidos processos. (...) Exercer atribuições que, acerca de ajuntamentos ilícitos, concedem as leis em vigor. (...) Ter sob sua severa vigilância as mulheres de má vida, providenciando contra elas, na forma da lei, quando ofenderem publicamente a moral e os bons costumes."
}

Diante de pontos da legislação podemos perceber as tentativas de normatização de aspectos diários da vida de sujeitos, notadamente pobres, no espaço urbano. As autoridades competentes, policiais nesse caso, possuíam todo o aparato legal necessário para empreender uma espécie de "limpeza" da cidade, então em intensa e constante transformação, dos segmentos sociais vistos como obstáculos ao desenvolvimento.

Em estudo sobre a vida cotidiana da população pobre de Santos na transição do século XIX para o século XX, Leandro Alonso afirma que:

\footnotetext{
“As autoridades policiais encaravam a população pobre de forma homogênea. Não havia preocupação em considerar as especificidades do que cada um fazia, apenas se distinguia sua inserção ou não no mundo produtivo. Caso o sujeito estivesse em sintonia com a norma social juridicamente delimitada, seria bem aceito, caso contrário seria repudiado. No último caso, o poder de reprimir da forma que melhor conviesse, conforme o que estava previsto na lei, era utilizado sem titubeios por parte do aparato de repressão presente na municipalidade." (ALONSO, 2012, p. 64-65)
} 
Seja vigiada pelo poder, ameaçada pelas enfermidades ou mesmo buscando meios para obtenção de trabalho e condições mínimas de subsistência, a situação de vida da população pobre e trabalhadora de Santos era bastante precária.

A análise feita por Marília D. Klaumann Cánovas (2017) sobre os locais de moradia de parte significativa desses trabalhadores - estrangeiros, fundamentalmente - nos oferece indícios interessantes. Segundo o estudo realizado, suas habitações ficavam majoritariamente circunscritas a ruas e bairros populares da cidade que, obviamente, apresentavam condições sanitárias no mínimo inadequadas (ver imagens 23 e 24, p. 89). Muitos viviam nos morros, locais onde se encontravam as duas etnias mais representativas dos imigrantes europeus que chegavam a Santos: os portugueses e os espanhóis (LANNA, 1996, p. 123). Ali residiriam, conforme Lanna, aqueles ocupados na rede de serviços urbanos como carroceiros, pedreiros, carregadores e trabalhadores do porto em geral, assim como os trabalhadores das pedreiras os chamados "canteiros" -, que abasteciam a Companhia Docas para as obras de modernização do porto.

Pelo recenseamento de 1913, o morro de São Bento era o mais populoso deles, com 1.240 indivíduos, sendo mais de $60 \%$ deles portugueses de nascimento. Seguia-se a ele o morro do Fontana (595 pessoas), o da Penha (358), o do Pacheco (295) e o do Jabaquara, com 110 pessoas. Em uma população total de quase 90 mil pessoas, pouco menos de 20 mil viviam na denominada "zona rural", onde se situavam os morros. Nesse período, ainda segundo o censo, a cidade possuía 7.830 domicílios, sendo 897 "mistos" (as habitações coletivas ou cortiços). Era justamente nesses locais, os morros e as habitações coletivas, que grande parte dos trabalhadores da cidade, portugueses e espanhóis em sua maioria, residia em condições sanitárias lastimáveis (CÁNOVAS, 2017, p. 178).

As evidências quanto ao cotidiano dos trabalhadores na cidade de Santos, em que pese algumas diferenças discutidas posteriormente, devem ser consideradas na chave das freqüentes greves reivindicatórias (ver imagens 3 e 4, p. 79) de que foi palco, quase sempre tendo como alvo "as grandes companhias ali estabelecidas, como a Docas, a Inglesa, a City e, em momento posterior, a Companhia Construtora de Simonsen." (FAUSTO, 1977, p. 137)

As péssimas condições de trabalho, os salários baixos, as precárias habitações e as eventuais epidemias provocaram a criação de diversas organizações de auxílio mútuo, especialmente entre os imigrantes europeus que aportavam em grande número na cidade. Entre elas, geralmente organizadas por nacionalidade, existiam o Real Centro Português, criado em 1897, a Associação Portuguesa de Socorros Mútuos D. Carlos I, de 1902, a Sociedade Protetora dos Portugueses Desvalidos, também de 1902, o Centro Espanhol, de 1895, a 
Sociedad Española de Socorros Mútuos y Instrucción, de 1900, a Sociedad Española de Repatriación, de 1902, a Societá di Beneficenza Italiana, de 1897, o Patronato Del Lavoro, de 1902 e a Sociedade Beneficente Austro-Húngara, de 1900. O objetivo dessas organizações era o de auxílio em caso de doença, desemprego e funeral e a construção de hospitais para os imigrantes de recursos mais escassos (FRUTUOSO, 1995, p. 34).

Essas associações foram criadas e dirigidas por pessoas que, no conjunto da colônia, representavam um pequeno grupo prestigiado e, muitas vezes, endinheirado, mas bastante minoritário e que, no exercício de atividades relacionadas especialmente ao comércio, importante meio de ascensão social e prestígio, alcançavam visibilidade e reconhecimento social (CÁNOVAS, 2017, p. 318). Embora dirigidas por pessoas bem posicionadas social e economicamente, tais entidades assistencialistas viviam sempre às voltas com crises financeiras que demandavam contínua mobilização e diversos artifícios como campanhas de arrecadação de fundos, rifas e pedidos de doações (FRUTUOSO, 1995, p. 55). Interessante notar que as constantes crises financeiras provocadas em larga medida por uma intensa oscilação na carteira de associados dessas organizações - refletindo a flutuação na condição financeira de seus afiliados - encontrariam correspondência, pouco tempo depois, nas cíclicas crises financeiras vivenciadas pelas primeiras agremiações dedicadas ao futebol na cidade de Santos. O caráter instável e muitas vezes efêmero de tais agremiações será discutido em mais detalhes no próximo capítulo.

As organizações de auxílio mútuo seriam parte de um processo mais amplo de construção de sociabilidades identificadas a partir do mundo do trabalho. Se, por um lado, como citado, havia a ajuda em caso de desemprego por parte dessas organizações, havia, por outro, essencialmente a luta - organizada e combativa - de trabalhadores locais em busca de melhores condições de vida.

\subsection{Os trabalhadores da cidade de Santos: organização, luta e resistência}

A formação da classe operária em Santos (ver imagem 25, p. 90), extremamente influenciada pela maciça presença de trabalhadores estrangeiros e entendida aqui sob a perspectiva de Thompson (2011) de formação como um processo ativo que se deve tanto aos condicionamentos sociais e econômicos como pela ação humana cotidiana, começa a ser percebida a partir do surgimento das primeiras greves, ainda na segunda metade do século XIX. 
A greve, naquele contexto, representava um instrumento de coesão, uma arma legítima na tentativa de obter alguns direitos, como aumento salarial ou, em alguns casos, a simples manutenção do valor pago, assim como o seu recebimento em dia, a redução da jornada de trabalho para oito horas e mais segurança no trabalho, onde os acidentes eram freqüentes.

Entre as décadas de 1870 e 1880, carregadores de café, trabalhadores da construção civil e trabalhadores do porto de Santos paralisariam as suas atividades e, em 1891, a cidade presenciaria a primeira greve geral de nível local no país (GITAHY, 1992). No entanto, antes de uma análise mais detida sobre os trabalhadores santistas do final do século XIX e princípios do século XX, acredito ser fundamental adensar a reflexão sobre a concepção do operariado como classe no período.

A formação da classe operária (não apenas em Santos, mas no Brasil) é costumeiramente pensada como um fenômeno puramente econômico associado ao surgimento da indústria e à imposição do trabalho assalariado sem a concorrência do trabalho escravo após a abolição de 1888. Entretanto, uma das críticas recentes aos estudos baseados nessa perspectiva é a de que tomavam a ideia de classe como um efeito quase mecânico da estrutura produtiva, deixando de considerar que a existência de trabalhadores fabris em si não assegura a existência de uma classe, o que pressupõe interesses coletivos constituídos na experiência comum (BATALHA, 2010). A formação de classe seria, portanto, um processo mais ou menos demorado, cujos resultados podem ser verificados na medida em que concepções, ações e instituições coletivas, de classe, tornam-se realidade (THOMPSON, 2011, p. 22).

Nos estertores do século XIX, a ainda acanhada cidade presenciaria a primeira grande greve, generalizada e de ampla dimensão, de que se tem notícia na história do movimento brasileiro: em 1891, irrompida pelos trabalhadores portuários, a greve rapidamente se alastrou por outros segmentos laborais, ganhando a adesão de mais de dois mil grevistas (HARDMAN e LEONARDI, 1982, p. 58). A ela aderiram dos carroceiros aos trabalhadores da construção civil; dos ferroviários da Inglesa aos comerciários e bancários; dos canteiros aos trabalhadores das obras do porto. Na repressão que se seguiu, mais de quinhentos homens vieram da capital para apoiar os destacamentos locais, além de um encouraçado e dois cruzadores das Forças Armadas. O rápido estrangulamento do movimento grevista demonstrava a proximidade e influência junto ao governo federal do grande capital, nesse período representado principalmente pela Companhia Docas. A empresa, com efeito, demandava muitos operários nessa década, responsável que era pela construção do porto moderno. Inúmeras categorias laborais, além dos trabalhadores portuários, possuíam, em 
alguma medida, relação com a empresa, o que oferecia um ingrediente adicional de tensão em momentos de paralisação.

A organização operária em Santos - apesar das paralisações anteriores - adquire concretamente seus primeiros contornos a partir de 1904 com a fundação da Sociedade Primeiro de Maio, formada exclusivamente por trabalhadores da construção civil e cuja primeira reivindicação dizia respeito aos freqüentes e muitas vezes letais acidentes de trabalho. As empresas, por essa época, não tinham qualquer responsabilidade sobre essas fatalidades. Caso o empregado acidentado não pudesse comparecer ao trabalho, não receberia pelos dias de ausência (SARTI, 1981, p. 75). A pesquisa de Canóvas (2017), já citada, no traz informações valiosas sobre essa questão. Através da análise dos livros de obituário do Cemitério Municipal de Santos no período feita pela autora, podemos perceber que a condição dos operários na cidade, em especial os de pouca especialização e baixo ganho, era deplorável. Além da febre amarela, ainda representativa do maior número de óbitos de fins do XIX, aparecem como causa mortis acidentes claramente identificados com o trabalho no porto e na construção civil, como "asfixia por submersão", "esmagamento de cabeça", "esmagamento do crânio por acidente" e "apoplexia cerebral consecutiva a insolação" (CÁNOVAS, 2017, p. 335336). Ainda segundo a pesquisa, esses casos indicavam a tendência à concentração em poucas nacionalidades nos acidentes relacionados ao universo laboral, em especial portugueses, espanhóis e brasileiros.

Alguns meses depois da fundação da Sociedade Primeiro de Maio surge, com a pretensão de congregar operários de diversas áreas, a Sociedade Internacional União dos Operários. Embora fundada majoritariamente por trabalhadores ligados ao café, a Internacional teria, em pouco tempo, milhares de associados de diversos ramos de atividade. As paralisações se tornariam mais freqüentes, assim como as ações repressivas que, nesse momento, incidiam principalmente sobre os imigrantes europeus ligados à classe trabalhadora. Um exemplo claro do recrudescimento dessas ações reside na sanção presidencial, pelo então presidente Afonso Pena, do decreto 1.641, de 7 de janeiro de 1907. A lei de expulsão de estrangeiros - ou "Lei Adolfo Gordo", como passou a ser designada - atingia diretamente elementos ligados ao movimento operário. Promulgada, a lei autorizava a expulsão de líderes operários estrangeiros e o encarceramento de brasileiros que comprometessem a "segurança nacional". Mais do que a expulsão, porém, interessava imprimir sobre os acusados a marca da lei e reforçar o estereótipo de "perigosos", além de construir no imaginário das pessoas o "significado e o sentido negativo que o ideário anarquista representava, ou seja, produzir a figura do operário estrangeiro perigoso" 
(PINHEIRO e HALL, 1981, p. 265). Assim, ao mito do europeu como homem livre, ordeiro e trabalhador, construído pela sociedade republicana de fins do XIX, contrapunha-se a ação dos "desordeiros" anarquistas.

É nesse contexto de acirramento da postura repressiva, materializada pela lei de janeiro de 1907, que podemos compreender a greve ocorrida em 1905 (ver imagem 4, p. 79) e a repressão subseqüente. Patrocinada pela recém-formada Sociedade Internacional União dos Operários, a paralisação tinha por objetivo combater o monopólio da Companhia Docas na determinação dos valores pagos pelas tarefas executadas e pela quantidade de horas trabalhadas (GITAHY, 1992, p. 68). Iniciada pelos estivadores, a greve contou com a participação de carregadores, trabalhadores dos armazéns, lixeiros, tecelões, barbeiros e carroceiros. Em resposta, a Internacional teve a sua sede invadida pela polícia e seus diretores foram presos.

Em abril de 1906, no Rio de Janeiro, aconteceria o Congresso Operário, elemento chave para a compreensão das influências ideológicas e das formas de ação adotadas pela classe operária santista naquele momento. $\mathrm{O}$ anarcossindicalismo, rejeitando a participação política formal e o envolvimento em questões religiosas e defendendo a jornada de trabalho de oito horas diárias, passa a ser predominante no movimento operário da cidade de Santos (GITAHY, 1992). Sobre essa questão, Angela de Castro Gomes (2005, p. 48) afirma que:

“O Congresso de 1906, contudo, não é situado como um acontecimento chave apenas porque suas resoluções configurariam a vitória de pontos fundamentais do ideário anarquista, demonstrando seu crescimento frente aos grupos existentes no movimento sindical da época. O significativo é que essa data assinalou um ressurgimento de ações de organização e de reivindicação entre os trabalhadores do Rio de Janeiro e de São Paulo, onde a presença dos anarquistas era fundamental. O Primeiro de Maio de 1906, as várias greves ocorridas no Rio no segundo semestre deste mesmo ano, a greve paulista de 1907, as paralisações em Santos, a formações da Federação Operária do Rio de Janeiro (FORJ) e a publicação entre 1908 e 1909 do jornal A Voz do Trabalhador dão bem a idéia da força desta proposta no interior do movimento operário."

As greves pelas oito horas de trabalho se espalham por diversas categorias profissionais da cidade. Em 1907, em assembleia geral, é criada a Federação Operária Local de Santos (FOLS), composta pelos sindicatos de pedreiros, carpinteiros, pintores, funileiros, 
carregadores de café e tecelões. Ligada ao anarcossindicalismo, a FOLS seria, ao lado da Internacional, responsável pela articulação de grande parte das greves que irromperam no período.

Em 1908, nova greve tem início na Companhia Docas de Santos, paralisando toda a cidade, com enfrentamentos de rua e com a presença de dois navios de guerra enviados à cidade pelo governo federal. Organizada inicialmente pela Internacional e com adesão da FOLS, a greve por redução da jornada de trabalho acabou com a prisão de novecentos operários, oito mortes e mais de cem pessoas feridas, segundo edição do jornal $A$ Tribuna de novembro do mesmo ano.

À movimentação operária, entrementes, a cidade se modernizava, metamorfoseandose radicalmente, tributária de suas atividades comerciais, das exportações de café e das reformas urbanas. Em agosto de 1907, quase que alheia às agitações operárias que sacudiam a cidade, seria realizada, com a presença de diversas autoridades, como o presidente do Estado de São Paulo, Jorge Tibiriçá, a festa de inauguração dos trechos construídos dos canais de drenagem. A cidade cosmopolita e moderna que se configurava não conseguia disfarçar o seu avesso, impregnada de paradoxos. Essa era a face contraditória daquele ambiente urbano que se projetava, cujo descompasso se expressava nas lutas diárias por sobrevivência e trabalho digno.

O histórico de lutas e resistência reforçava o mito da "Barcelona Brasileira", forjado nas precárias condições de trabalho, nos baixos salários, na violência da repressão e das deportações, mas também nas greves, na organização e na combatividade da classe operária local.

É preciso, no entanto, cuidado ao extrair das características econômicas da cidade e da origem e composição étnica dos trabalhadores, relações diretas com o comportamento político e ideológico da classe operária santista. A presença marcante de imigrantes na formação do operariado de Santos não fez de sua classe operária algo coeso e homogêneo ou tampouco determinou as influências ideológicas dos trabalhadores locais. A existência de diferentes entidades representativas dos trabalhadores da cidade, como a FOLS, a Internacional, a Primeiro de Maio e diversos sindicatos autônomos, assim como as distintas formas de ação utilizadas pelas categorias profissionais existentes evidenciam o caráter complexo do movimento operário santista. Entre a "ação direta" e o "reformismo", milhares de sujeitos, trabalhadores, lutavam por condições reais e objetivas de existência.

Embora o número expressivo de imigrantes do Velho Mundo tenha, efetivamente, influenciado a configuração da classe trabalhadora santista, é necessário enfatizar que essas 
relações não se deram de forma mecânica ou determinista. Durante muito tempo, vigorou a tese de que havia uma correlação direta entre a maciça presença de imigrantes no Sul e Sudeste do país, a militância política e as influências ideológicas do movimento operário. Na medida, porém, que os estudos sobre o tema se aprofundaram, essa relação passou a ser vista com constante reserva. $\mathrm{O}$ que esses estudos sobre imigração mostraram recentemente é que a imensa maioria dos imigrantes provinha do campo, não das cidades, e, na maioria das vezes, não tinham qualquer experiência prévia de engajamento sindical ou político (BATALHA, 2000 e TOLEDO, 2002). Em muitos desses estudos, a composição étnica aparece, inclusive, como entrave, como elemento mais de dissenso do que de consenso entre os trabalhadores. As eventuais rivalidades impulsionadas pelas diferentes origens étnicas e nacionais ora provocavam aproximações, ora provocavam distanciamentos.

Em Santos, por exemplo, a nacionalidade aparecia como elemento agregador importante. Criava redes de sociabilidade e solidariedade - associações de auxílio mútuo, clubes e, posteriormente, times de futebol - que podiam garantir proteção, trabalho, moradia e lazer. Embora a convivência no universo do trabalho gerasse tensões internas às classes trabalhadoras da cidade, a nacionalidade "criava solidariedades que ultrapassavam o universo das classes e desigualdades sociais" (LANNA, 1996, p, 217).

Além dos componentes econômicos e étnicos, as distinções existentes entre trabalhadores dos setores público e privado evidenciam o caráter heterogêneo da classe trabalhadora de Santos. Em publicação de junho de 1911, o periódico operário local $O$ Proletário (ver imagem 22, p. 88) dá mostras das especificidades das condições de trabalho das diferentes categorias profissionais da cidade. Enquanto os sindicatos da construção civil haviam assegurado o seu reconhecimento (closed shop) e a jornada diária de oito horas de trabalho, a situação dos trabalhadores do saneamento (ver imagens 5 e 6, p. 80), ligados ao governo do Estado, era descrita nos seguintes termos:

\footnotetext{
“Enquanto nas obras particulares se trabalha oito horas, lá sendo uma repartição pública os trabalhadores são forçados a trabalhar onze ou doze horas por dia. Quem conhece aquele serviço sabe perfeitamente o quanto ele é nocivo à saúde e quanto é repugnante. Mas mais revoltante é o salário. [...] Enquanto os engenheiros e chefes recebem somas fabulosas, os trabalhadores comem um muito rude pedaço de pão de modo a não morrer de fome. São insultados pelos feitores que são canalhas. A imprensa de grande formato se desfaz em elogios a essa Comissão (de Saneamento),
} 
esquecendo-se de que esses serviços estão sendo prestados por todos que lá trabalham, vegetando na mais negra miséria."

O fragmento acima nos proporciona elementos interessantes para a discussão da contraditória sociedade que se configurava na cidade de Santos no princípio do século. As reformas urbanas de caráter sanitarista, entoadas em verso e prosa por parte da imprensa e por expressivos setores das elites locais, são retratadas aqui sob o prisma de quem cotidianamente a tornou possível. O caminho rumo à modernidade escondia em si os tortuosos obstáculos da exploração do trabalho.

Os últimos anos da primeira década do século XX e o início da década de 1910 são anos difíceis para o operariado santista. A violenta repressão de 1908 citada anteriormente promovida por iniciativa da Companhia Docas (ver imagens 13 e 14, p. 84) sobre os portuários grevistas, contando inclusive com a atuação de fuzileiros navais e tropas de infantaria e cavalaria (HONORATO, 1996), e o subseqüente desemprego decorrente da crise econômica do período levaria o movimento operário da cidade a aglutinar-se na Federação Operária Local de Santos em torno dos trabalhadores da construção civil.

O ano de 1912 registraria, sob a égide da FOLS, uma grande greve contra a carestia de vida com a participação de carpinteiros, pintores, pedreiros, canteiros e estivadores. Em boletim de maio de 1912, a Federação justificava a paralisação da seguinte forma:

\footnotetext{
"O aluguel das habitações elevou-se consideravelmente tendo os inquilinos que pagar 40 ou 50 mil réis por quartos que não passam de cubículos onde se amontoam em espantosa promiscuidade as numerosas famílias. 0 pão, o café, a carne e outros gêneros são objetos de luxo e alguns foram elevados em $100 \%$ nos seus preços. Não se pode ocultar a triste realidade: nos lares proletários lavra a fome negra e a miséria horripilante." (Apud: CÁNOVAS, 2017, p. 363)
}

Curiosamente, a luta contra a carestia de vida acontecia em meio a um vertiginoso salto de crescimento da cidade. No ano anterior, a administração municipal havia divulgado indicadores econômicos que mostravam que a cidade havia crescido sete vezes desde 1889 (SILVA, 2003, p. 275). Havia uma febre de construções na cidade com as obras do porto e de saneamento urbano sendo realizadas. No primeiro semestre de 1912, seria criada a Companhia Construtora de Santos (ver imagem 16, p. 85), de Roberto Simonsen (ver imagem 17, p. 86), empresa que se tornaria fundamental para a expansão urbana santista e para a 
compreensão das relações envolvendo a ocupação dos espaços e a prática do futebol na cidade de Santos.

Evidentemente que a moderna cidade e seu avesso, de uma população pobre, imigrante ou não, em luta por moradia e contra a alta dos preços, encontraria nos períodos de maior atividade grevista um fortalecimento das ações repressivas. Nesse sentido, os anos de 1912 a 1914 assistiram ao acirramento da repressão policial, das deportações de estrangeiros e das prisões (BONFÁ, 2009, p. 22). Exemplo disso foi a greve dos canteiros (trabalhadores das pedreiras) de 1913, deflagrada pelo atraso no pagamento dos salários e a repressão que se seguiu.

Entretanto, apenas esses fatores não respondem às dificuldades da classe operária santista em meados da década de 1910. Em estudo sobre os trabalhadores de Santos no entreguerras, Fernando Teixeira da Silva destaca que as divisões internas, as diferentes concepções sobre o papel dos sindicatos na sociedade e as rivalidades e disputas no campo ideológico entre a até então hegemônica corrente anarcossindicalista e os "reformistas" também tiveram um peso relevante nesse processo. Sobre os adeptos do chamado "anarcossindicalismo de ação direta", o autor aponta que:

\footnotetext{
"Por trás da aparente homogeneidade e sinominia que envolve as denominações "sindicalismo libertário", "anarquista" e "revolucionário" escondem-se diversas concepções que, certamente, guardam pontos em comum, mas também apresentam diferenças e engendram divisões e conflitos no movimento sindical. Muitos anarquistas privilegiavam difundir as doutrinas ácratas nos sindicatos, enquanto os reformistas proclamavam a necessidade de representação política dos operários. Já os sindicalistas revolucionários escreviam em 1919 sobre a necessidade de organização como o único meio eficaz pelo qual o operariado pode conseguir o seu desideratum numa sociedade nova, livre e igualitária" (SILVA, 2003, p. 236).
}

Entre 1914 e 1918, com a economia em declínio, os operários perdiam seu poder de fogo. A repressão, igualmente, não arrefecia. Atingido pela crise, pelo aumento no custo de vida, pelas prisões de sindicalistas, fator que enfraquecia organizações como a FOLS, o movimento operário santista se retrai. Em Santos, os trabalhadores da construção civil, os únicos a se mobilizar nesse período de forma mais efetiva, encontravam dificuldades para impor uma pauta de reivindicações (SILVA e GITAHY, 1996, p. 14) 
Em 1917, quando ocorre a greve geral em São Paulo, marco do movimento sindical do país, os operários de Santos aderem e, em solidariedade, cruzam os braços, paralisando parcialmente a cidade. Um movimento tímido, levando em conta o histórico de amplas mobilizações na cidade.

Entretanto, a reorganização sindical em Santos ocorreria após o término da guerra e, em 1919, treze categorias entrariam novamente em greve, entre eles os trabalhadores das Docas, os canteiros, os trabalhadores dos armazéns, os motorneiros (dos bondes da City) e os trabalhadores da construção civil. Apesar da ampla adesão à paralisação de 1919 - seguida pela repressão evidenciada pelas 474 ordens de prisão para trabalhadores emitidas pelo delegado Ibrahim Nobre -, o sindicalismo de ação direta, mais comum entre os trabalhadores da construção civil, entraria nos anos 1920 profundamente abalado. A repressão patronal e policial, as deportações e condenações de lideranças associados a um nacionalismo xenófobo que despontava no pós-guerra contribuíam para a decadência dessa forma de organização (SILVA e GITAHY, 1996). A "maré vermelha”, nas palavras de Sheldon Maran (1979), tinha de ser contida a qualquer custo. Os alvos eram os "indesejáveis", espanhóis, portugueses e italianos da classe trabalhadora, "perigosos elementos" que deveriam ser expulsos pela concessão de amplos poderes ao Executivo.

É nesse contexto que surge, no final de 1920, um novo levante grevista na Companhia Docas, redundando, após dois meses de paralisação, em prisões em massa, invasão de sindicatos e demissão de trabalhadores. A segunda década do século XX termina, para os trabalhadores, com a repetição de um roteiro já conhecido e agora agravado por duas leis sancionadas pelo então presidente Epitácio Pessoa. As novas leis revigoravam a antiga Lei Adolfo Gordo, estendendo a possibilidade de expulsão de estrangeiros à possibilidade de "regulamentar a repressão ao anarquismo" e ampliavam os poderes - já utilizados na prática dos governos de intervir, por tempo indeterminado, em sindicatos e associações (SILVA, 1995, p. 78)

Os rápidos e violentos processos de transformação pelos quais passava a cidade de Santos foram vivenciados com especial truculência pelas classes trabalhadoras. A combatividade operária que rendeu para a cidade a alcunha de "Barcelona Brasileira" e mais tarde de "Moscouzinha" - pela influência crescente do Partido Comunista em fins dos anos 1920 - não se manifestava apenas no mundo do trabalho. Identidades se construíam na luta e no lúdico. É possível percebê-las em pequenas resistências e ações cotidianas. A disseminação do futebol como prática popular, amplamente difundida na cidade durante os anos 1910, se enquadraria nessa perspectiva. 


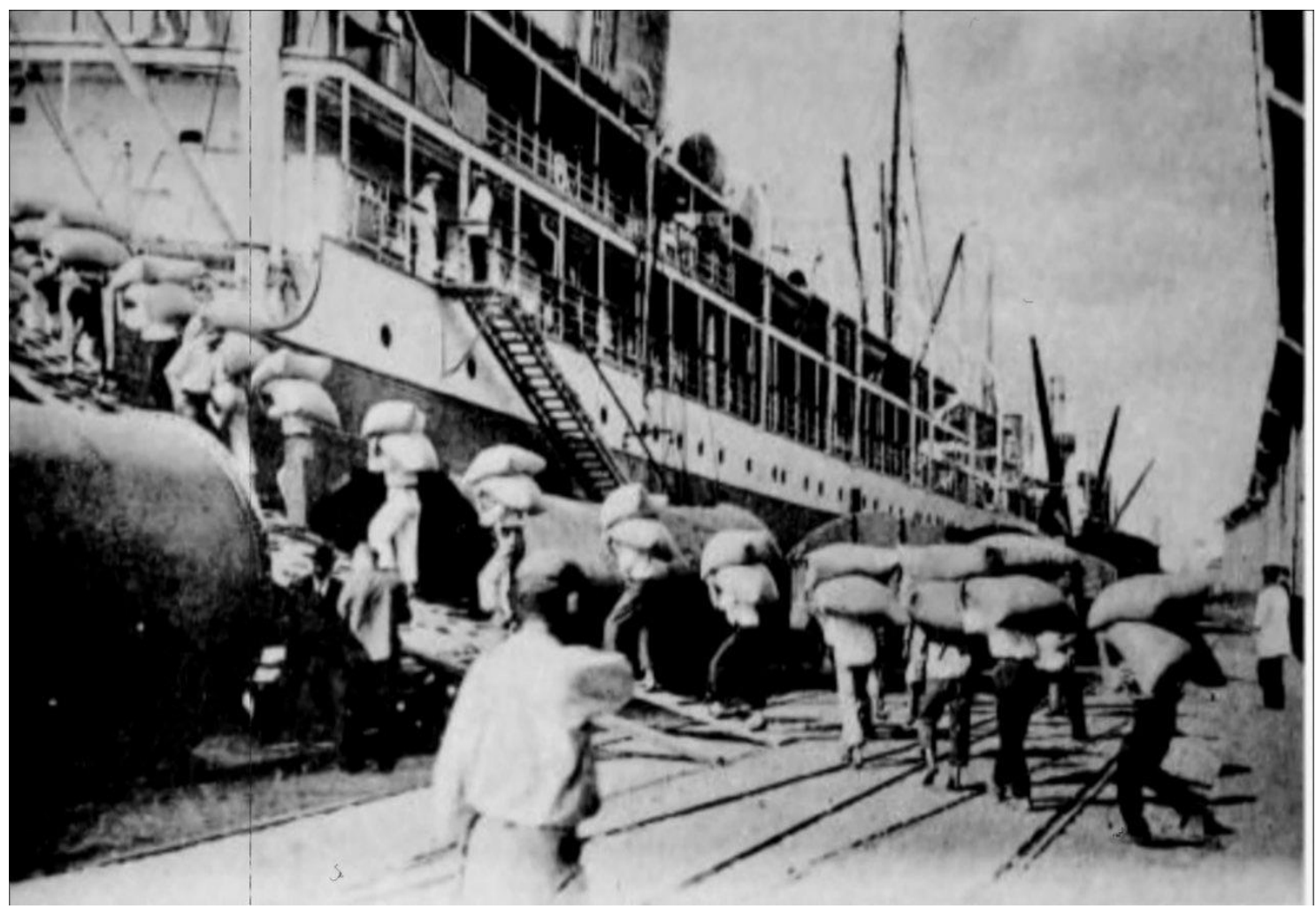

Imagem 1: Carregadores de Café, Década de 1900. Fonte: Fundação Arquivo e Memória de Santos.

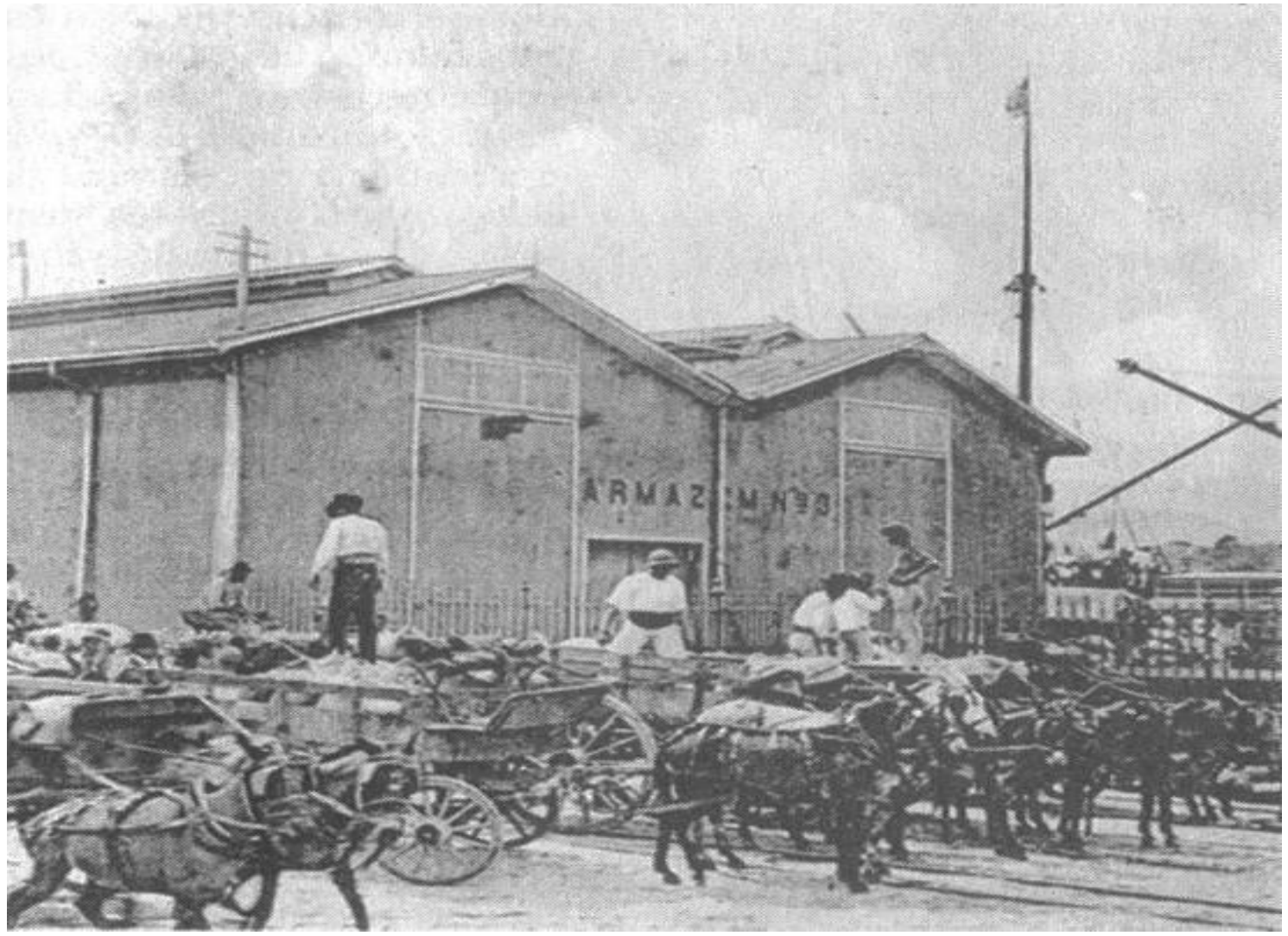

Imagem 2: Carroceiros no Porto de Santos. 1908. Fonte: Fundação Arquivo e Memória de Santos. 


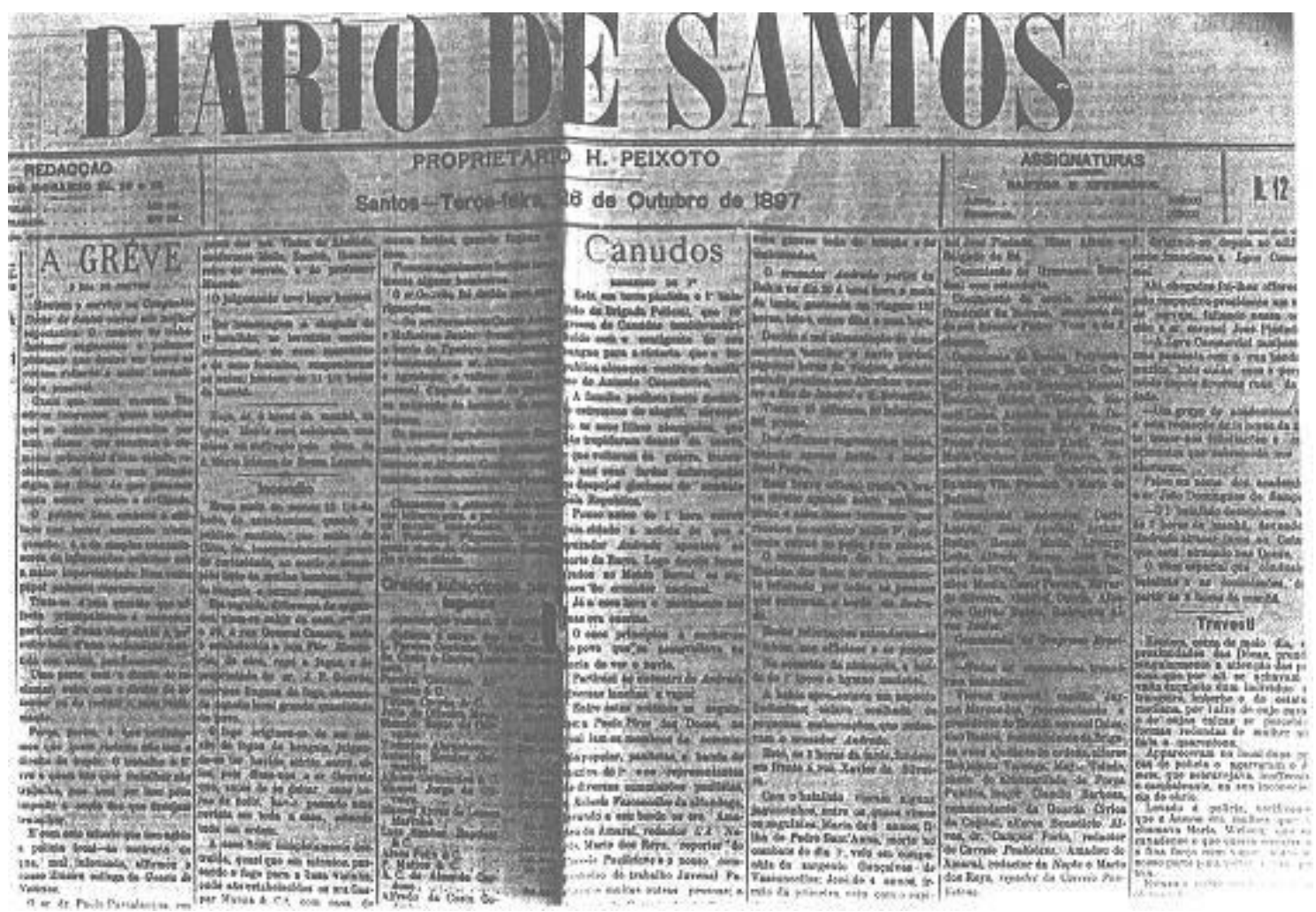

Imagem 3: Diário de Santos, 26 de Outubro de 1897. Fonte: Sociedade Humanitária dos Empregados do Comércio.

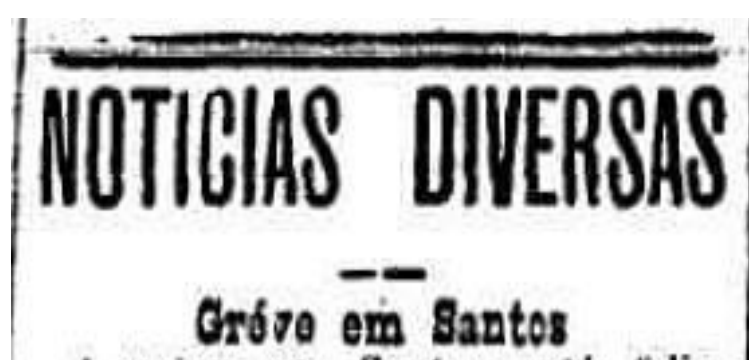

I trovie ens Sautos esta follizmente terminada.

Jurante o dia, o sr. dr. Neireiles lieis recehen informaries complrtas de toto o mosiniento ía arére a do camprimento das jure. videncias ieterinimadis.

do meinota o sr. dr. chefe de policia detiburou nomear o major Peciro Arhaes para o cargo de delergato etn fommissăn naquella ridate, nonicação que foi Jogo assizmada poile st. presilente do Estado.

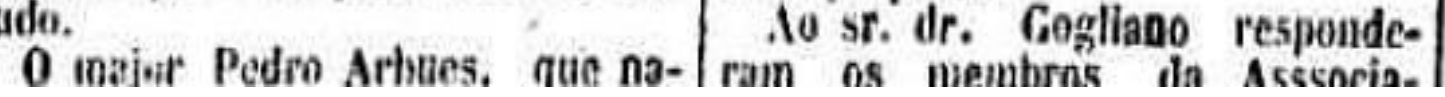

Imagem 4: O Estado de São Paulo, 20 de Junho de 1905. Fonte: Sociedade Humanitária dos Empregados do Comércio. 


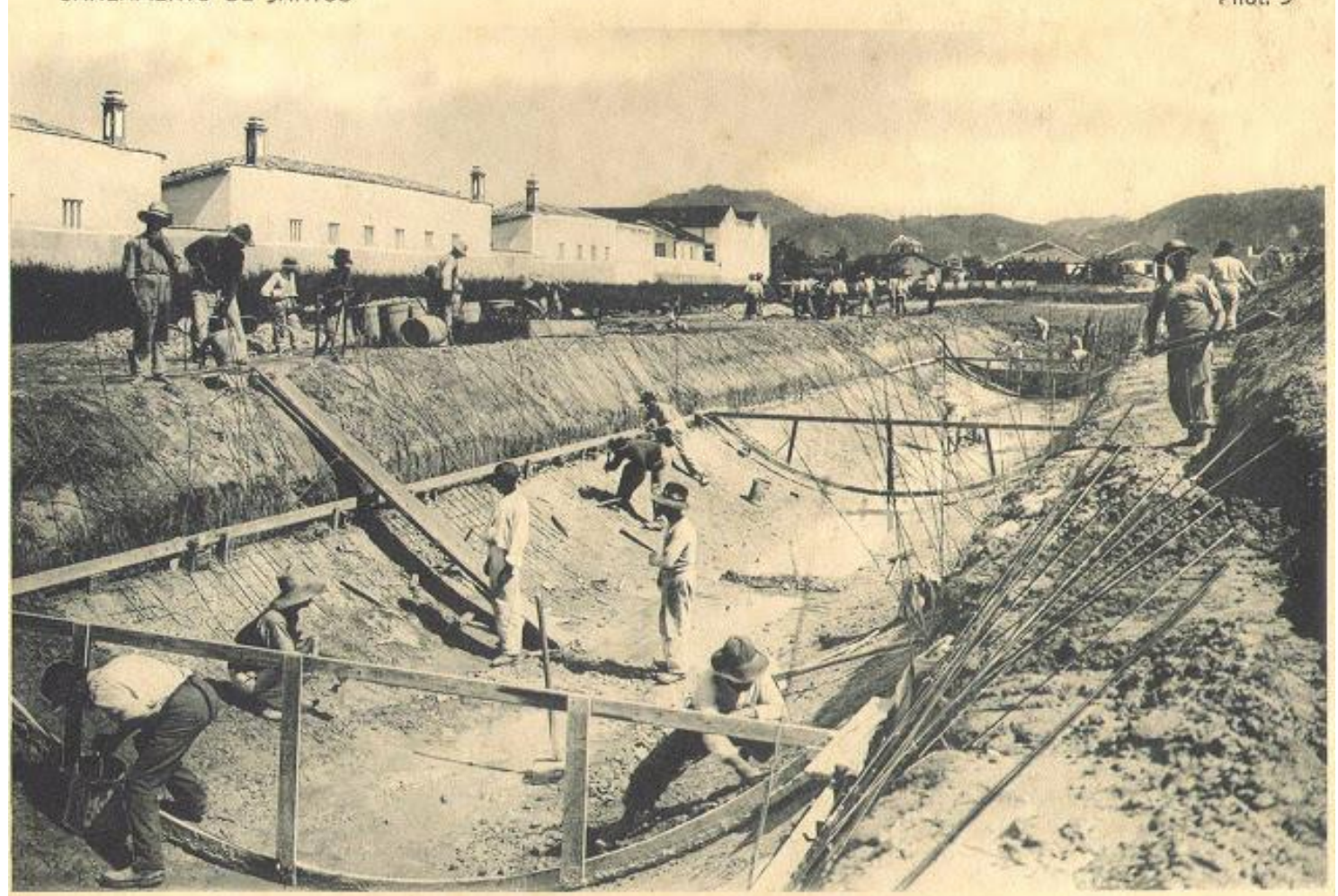

Canal de concreto armado: - execuçăo

Imagem 5: Trabalhadores do Saneamento, 1906. Fonte: Fundação Arquivo e Memória de Santos.

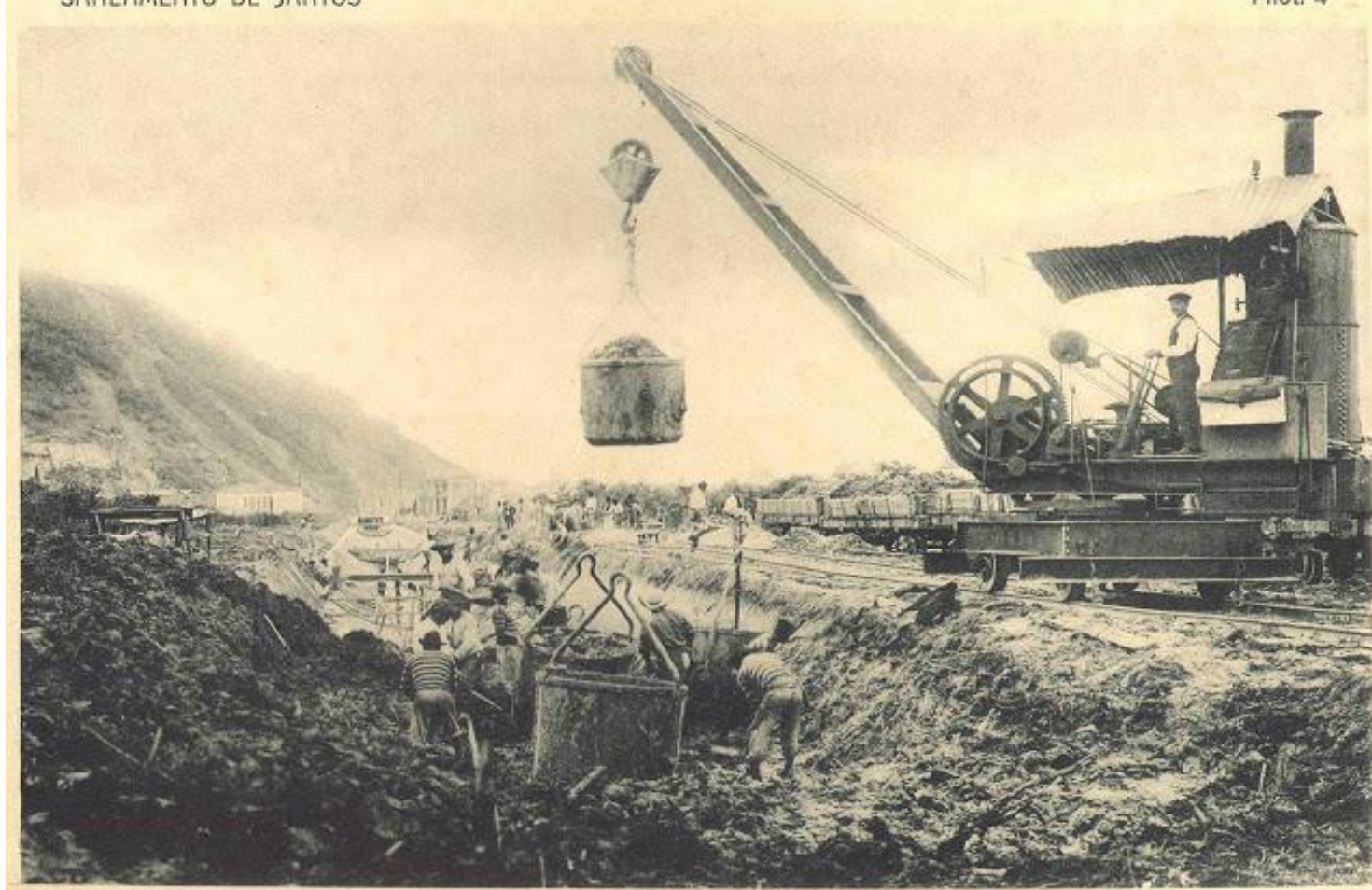

Canal de concreto armado: - excavação

Imagem 6: Trabalhadores do Saneamento, 1906. Fonte: Fundação Arquivo e Memória de Santos. 


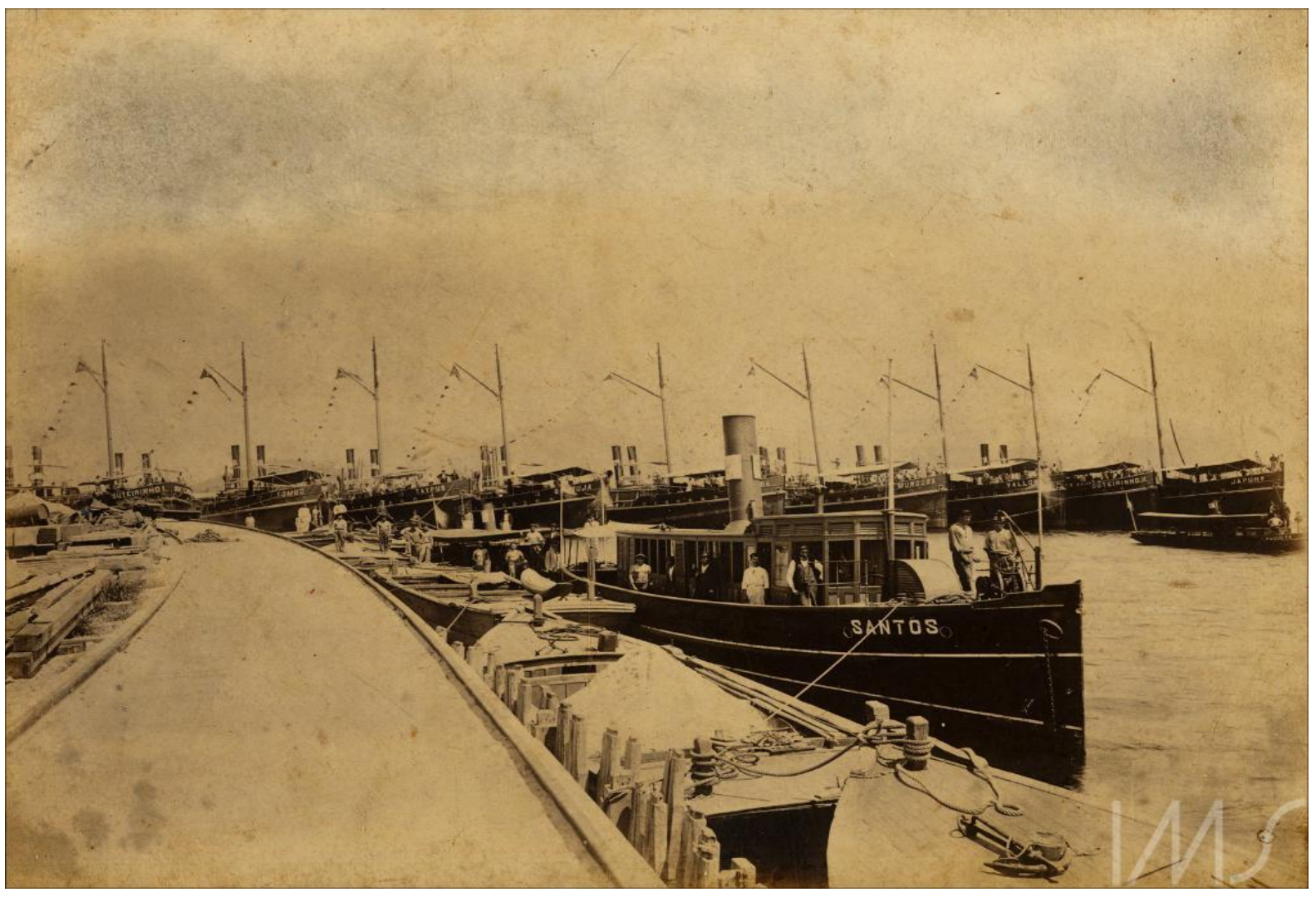

Imagem 7: Porto de Santos, 1901. Fonte: Instituto Moreira Salles.

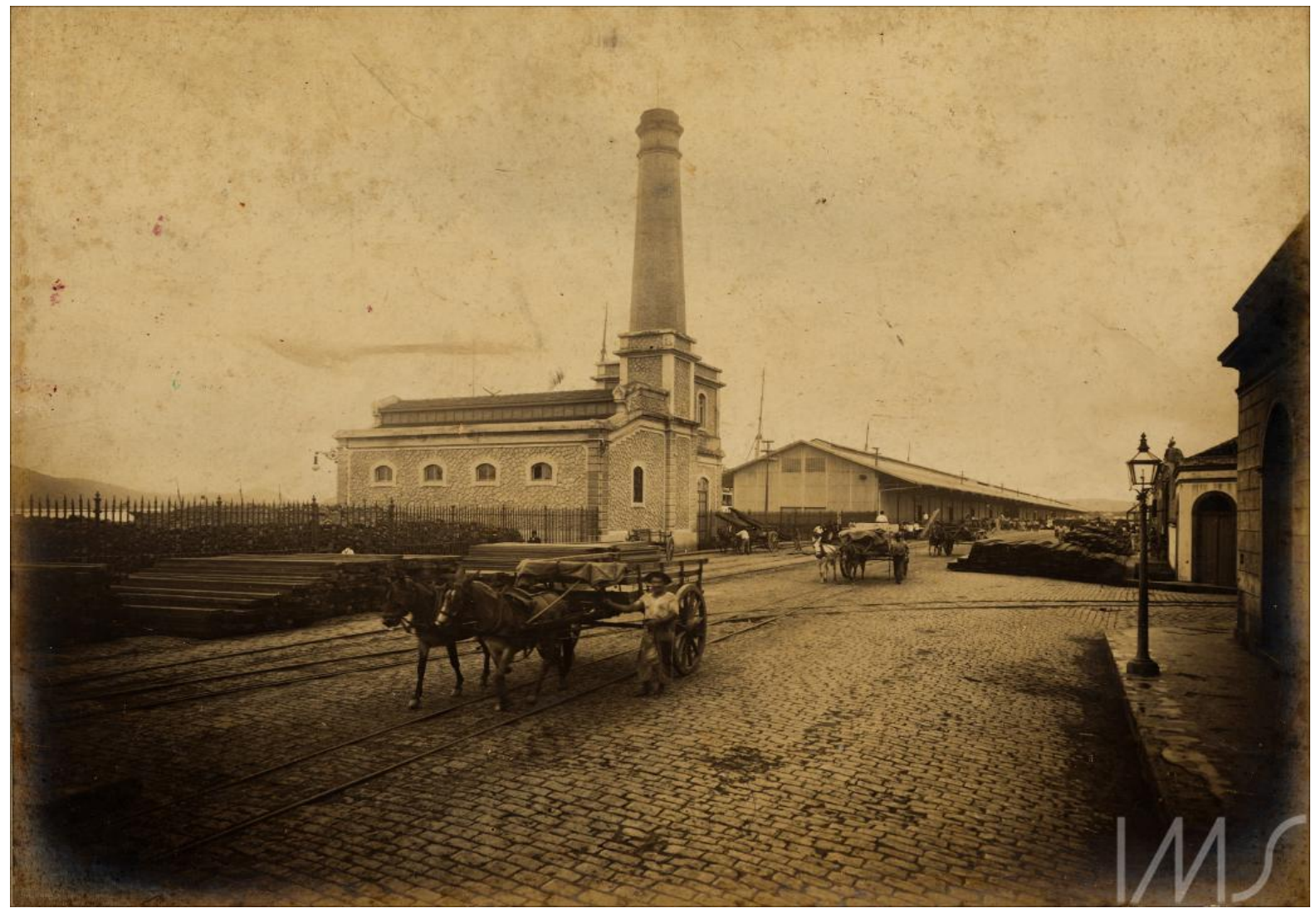

Imagem 8: Porto de Santos, 1901. Fonte: Instituto Moreira Salles. 


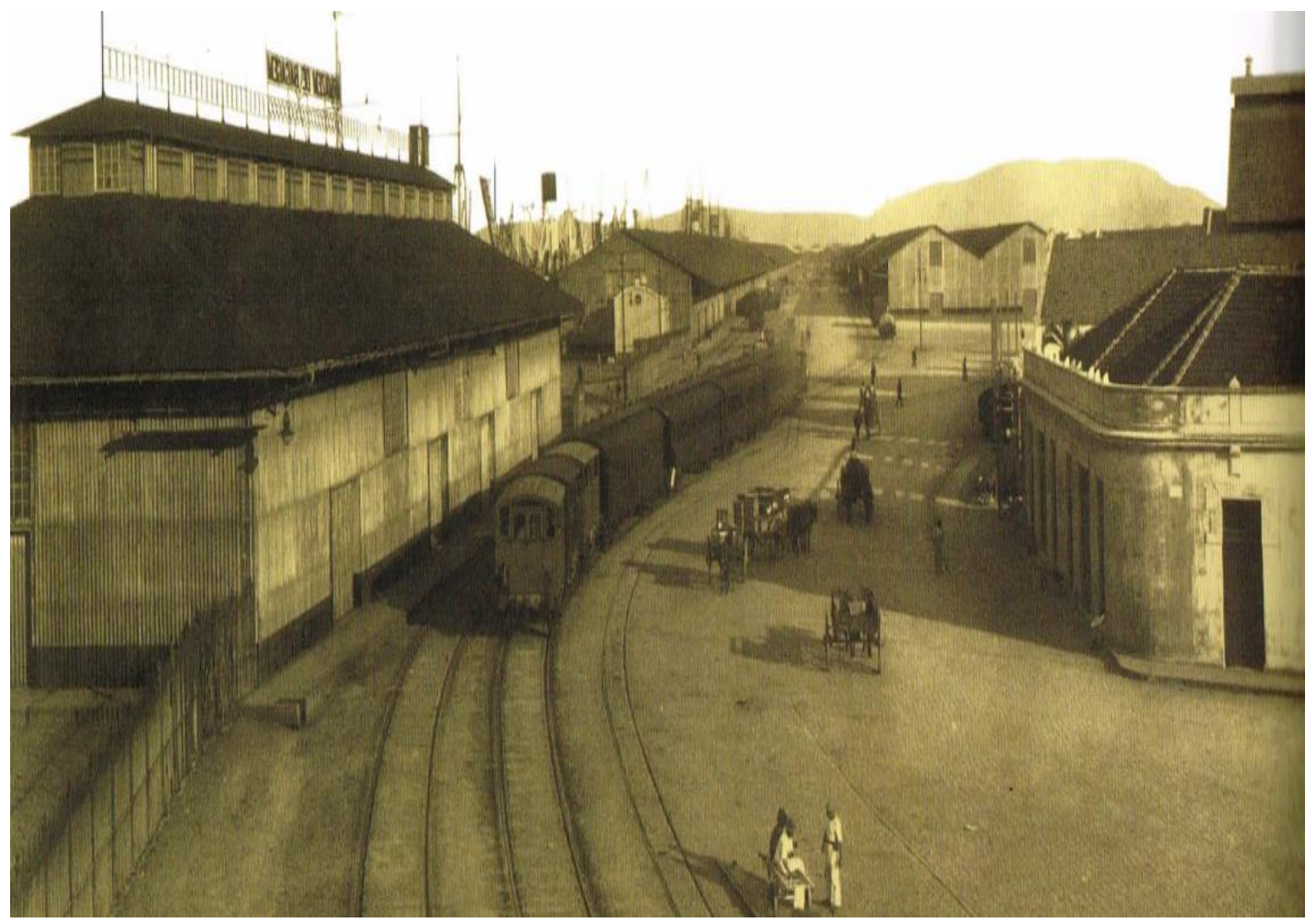

Imagem 9: Porto de Santos, 1902. Fonte: Instituto Moreira Salles.

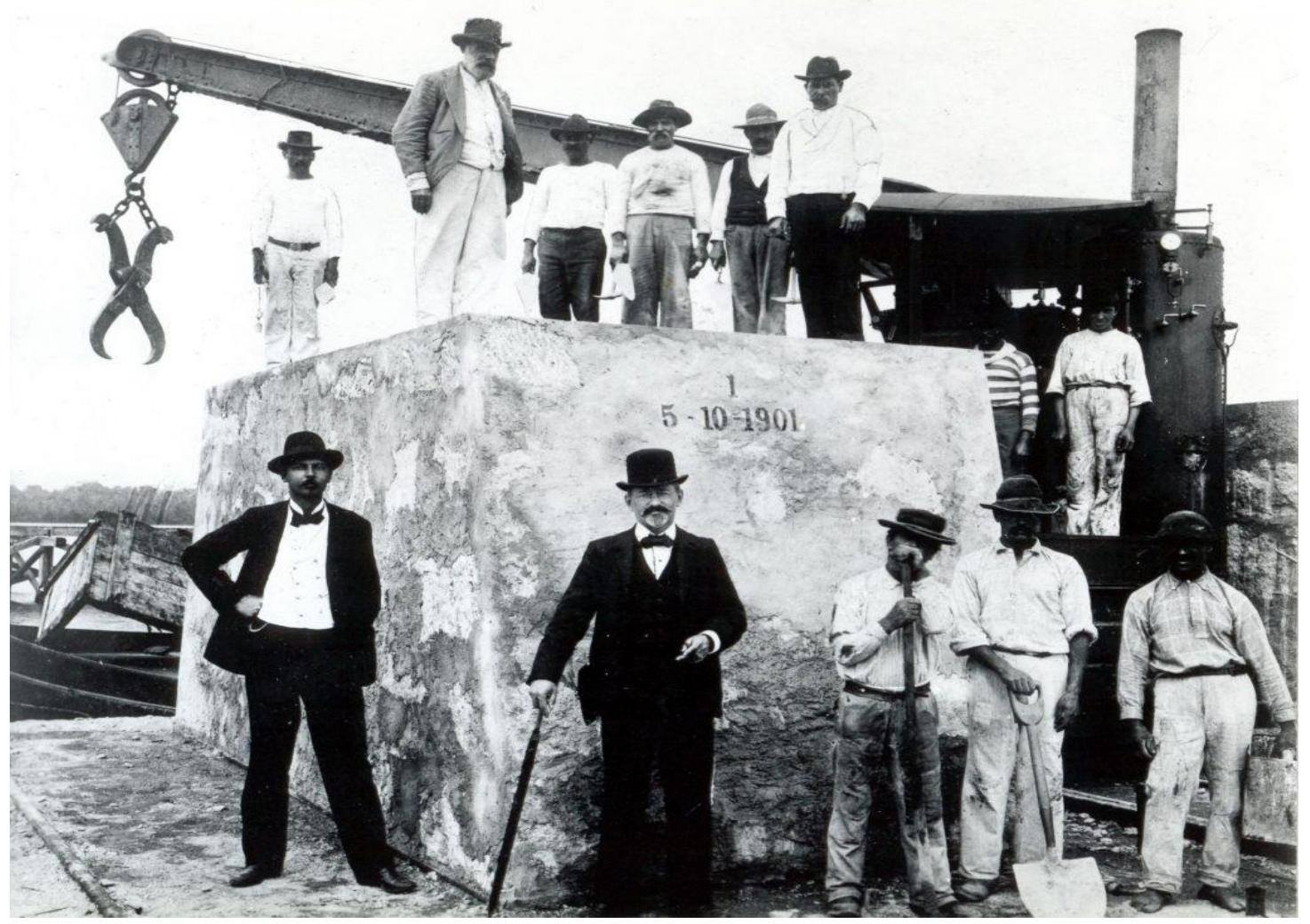

Imagem 10: Porto de Santos, Lançamento de Pedra Fundamental de Novo Trecho de Cais, 1901. Fonte:

Fundação Arquivo e Memória de Santos. 


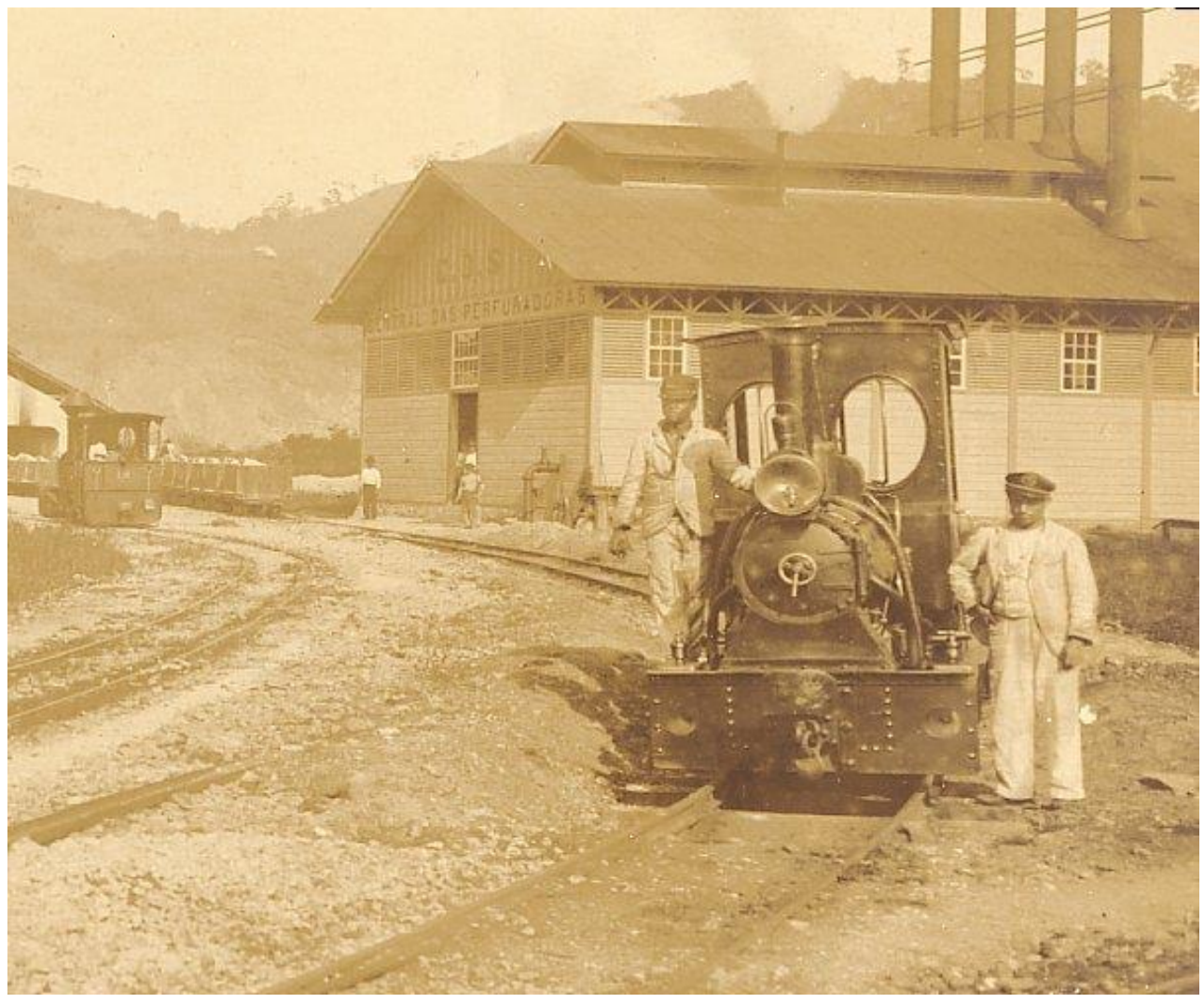

Imagem 11: Trabalhadores da Pedreira do Jabaquara, 1909. Fonte: Fundação Arquivo e Memória de Santos.

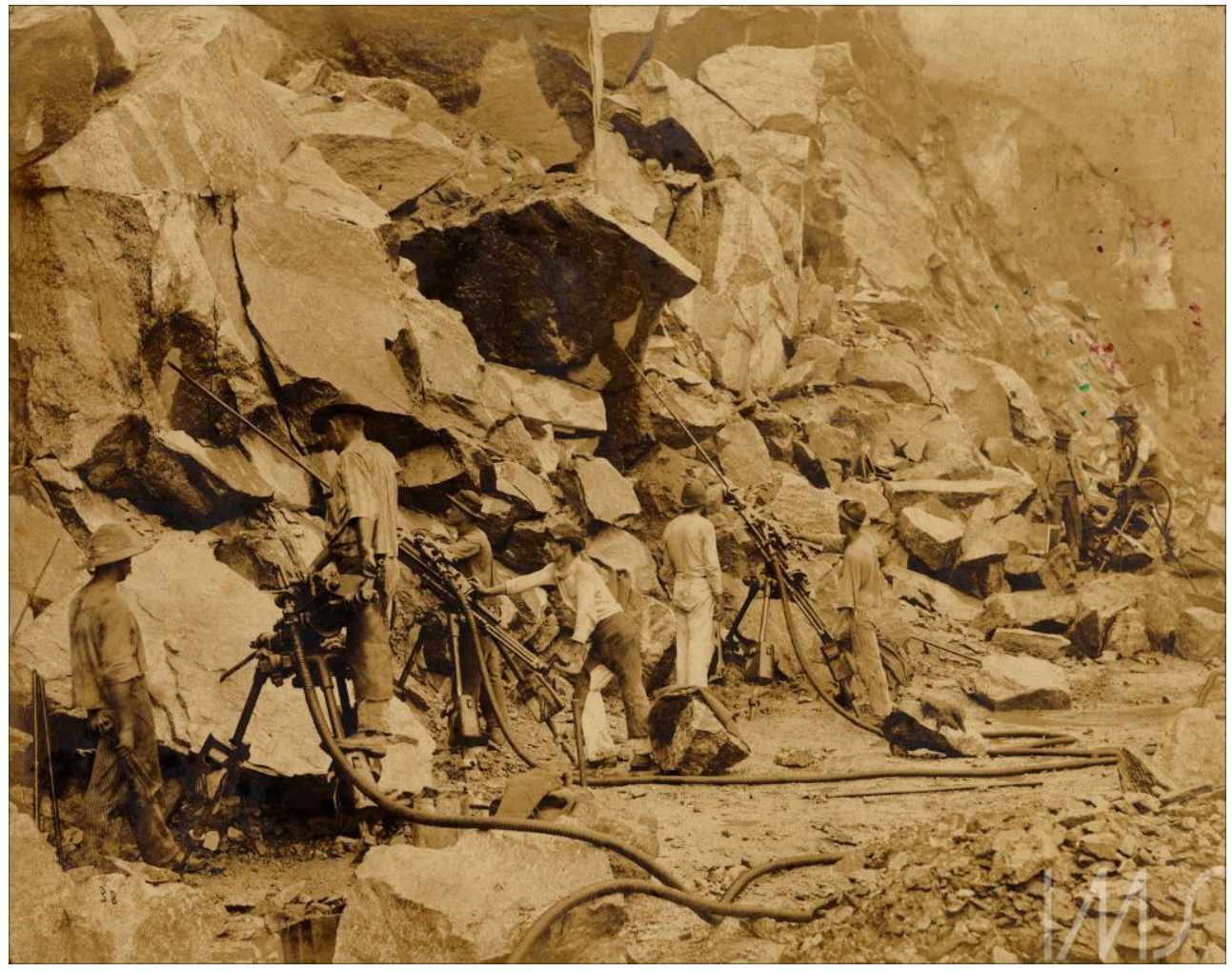

Imagem 12: Funcionários da Companhia Docas na Pedreira do Jabaquara, 1913. Fonte: Instituto Moreira Salles. 


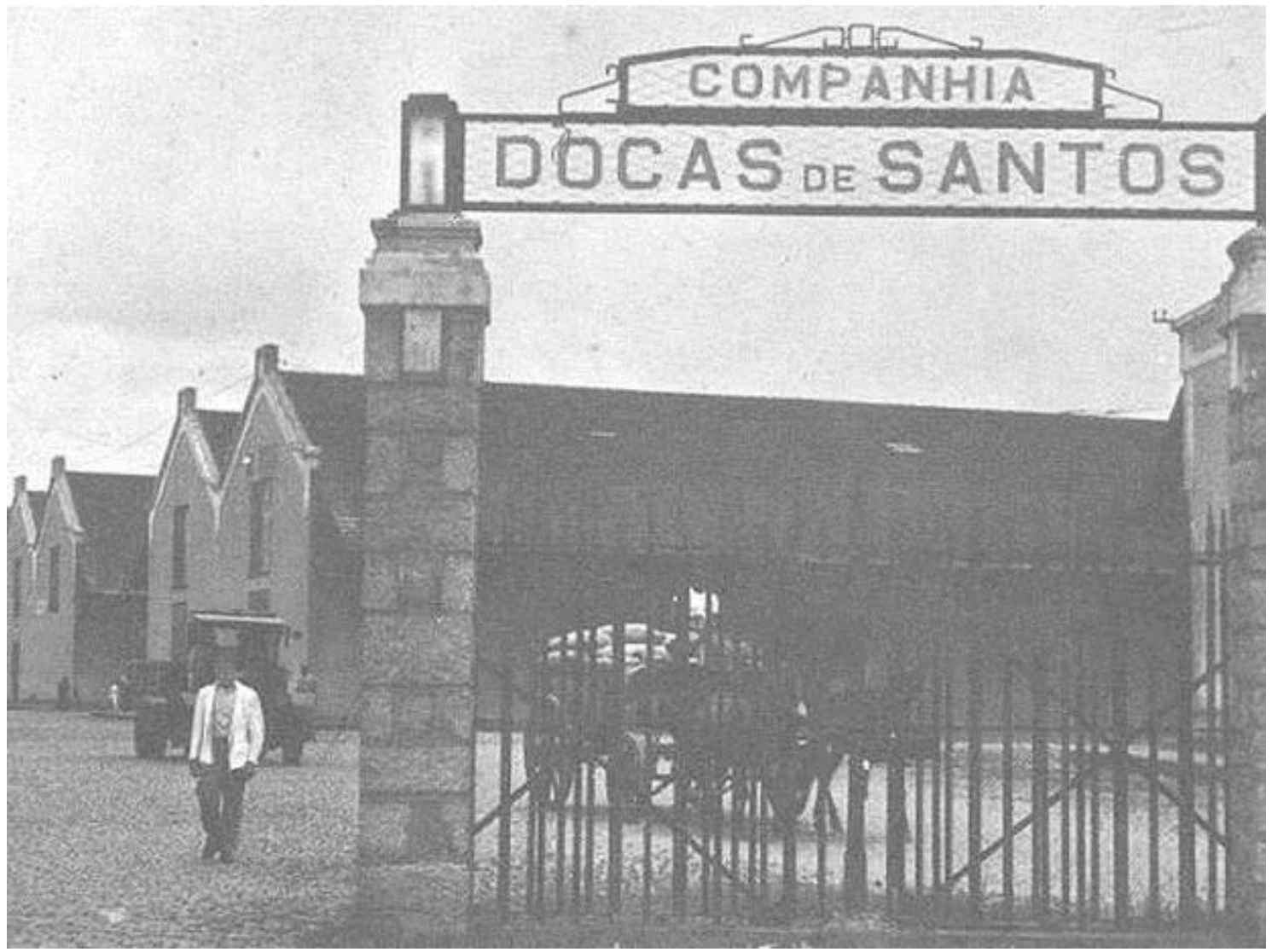

Imagem 13: Companhia Docas de Santos, 1899. Fonte: Fundação Arquivo e Memória de Santos.

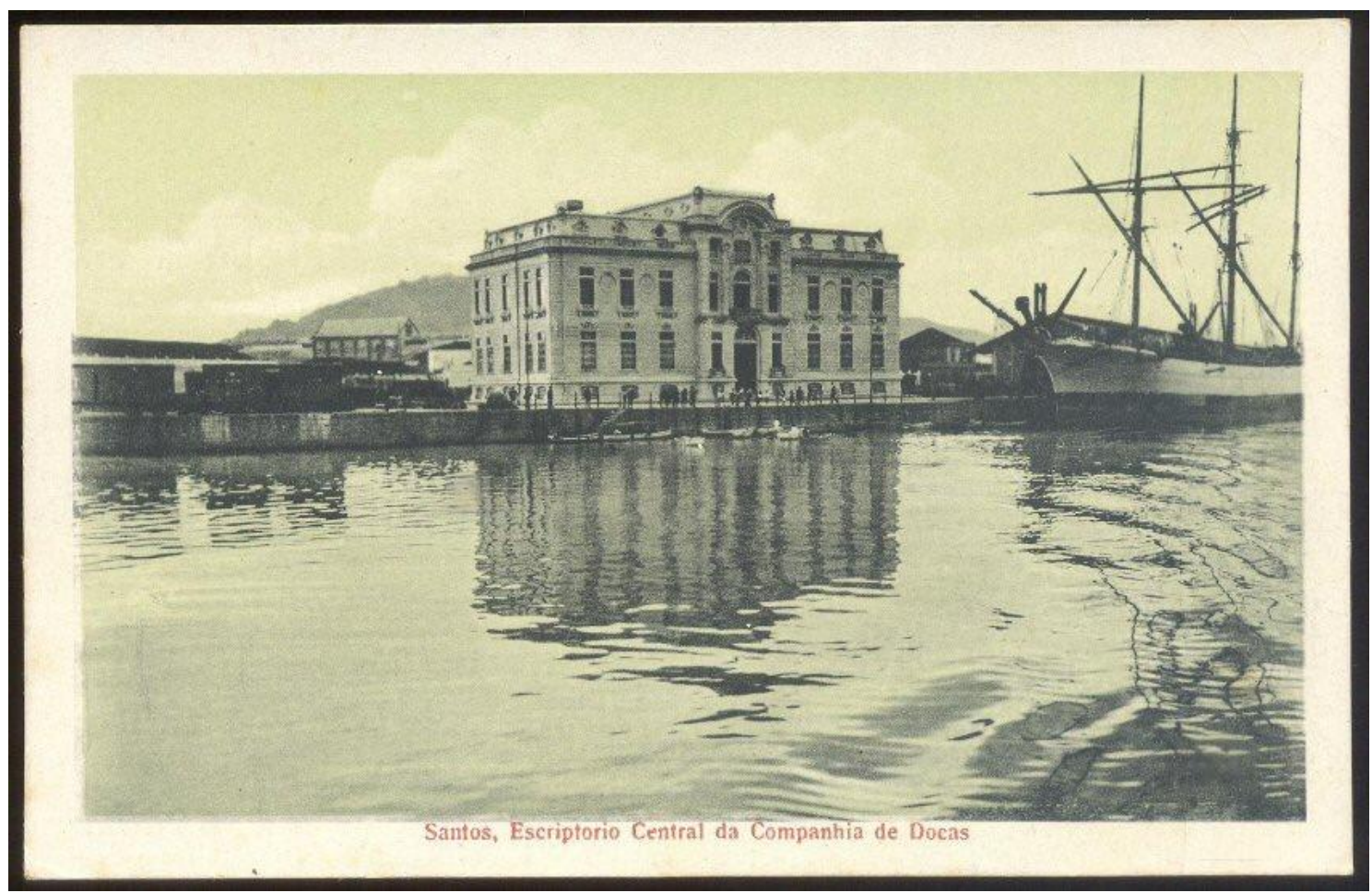

Imagem 14: Escritório Geral da Companhia Docas, sem data. Fonte: Fundação Arquivo e Memória de Santos. 
O COLOSSAL EMPREHENDIMENTO DE QUE RESULTOU A COMPANHIA DOCAS DE SANTOS, HONRA E ORGULHO DA ENGENHARLA NACIONAL.
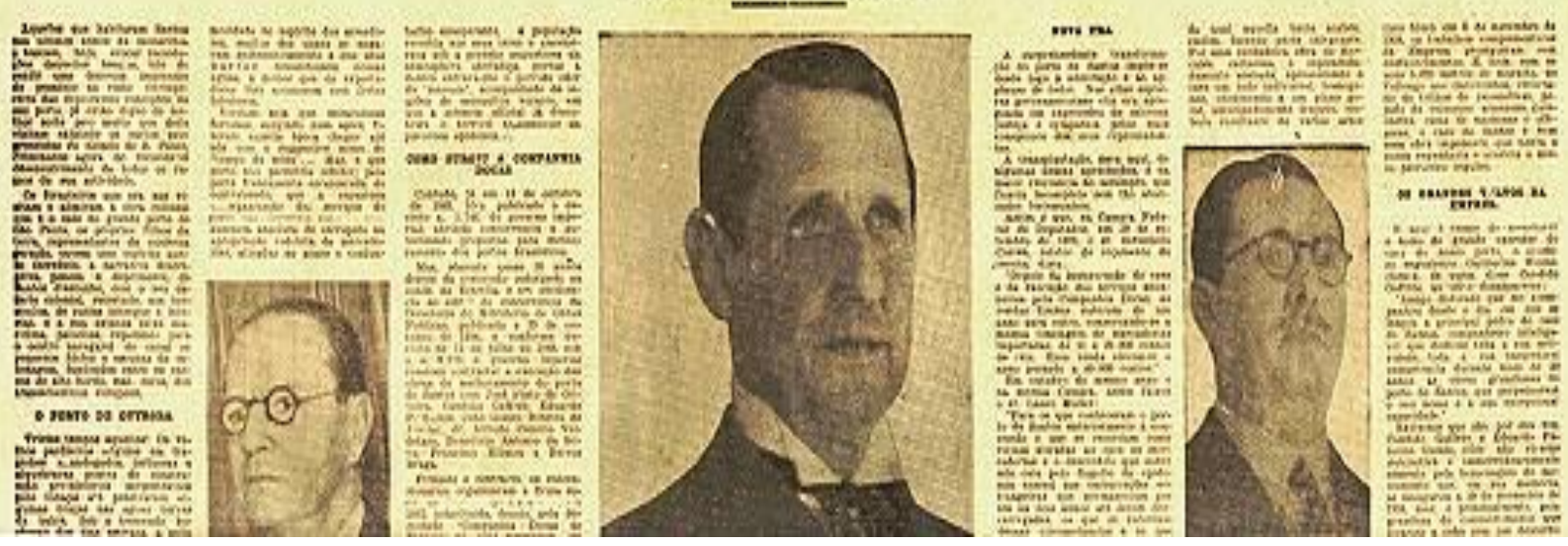

Imagem 15: A Tribuna, 26 de Janeiro de 1939, Edição Comemorativa. Fonte: A Tribuna

\section{COMPANHIA CONST RUCTORA DE SANTOS}

ENGENHEIROS ARCHITE CTOS E CONSTRUCTORES Endereço Telegr.: CONSTRUCTORA - CAIXA POSTAL, 222

RUA 15 DE ROVEMAR O N. $10-30^{\circ}$ A NDAR MPONTACÃO

Azulejos de louga - Ladrihos ceramicos - Aitigos Sanitarios - Ferragens - Chapas - Vigas part construcçũo - Tubos to ferro para agua e gaz - Cimento - Material de cimento aruado e pura pintura, etc. tador - Grande Eabrica de Lad rilhos e Manilhas de Cimento Seçz̃ de transporte

PIANTAS, PROYXCT OS E ONC.IMETOS

$$
-: \text { S A N T }
$$

Imagem 16: Diário de Santos, Anúncio da Companhia Construtora de Santos, 1913. Fonte: Sociedade Humanitária dos Empregados do Comércio. 


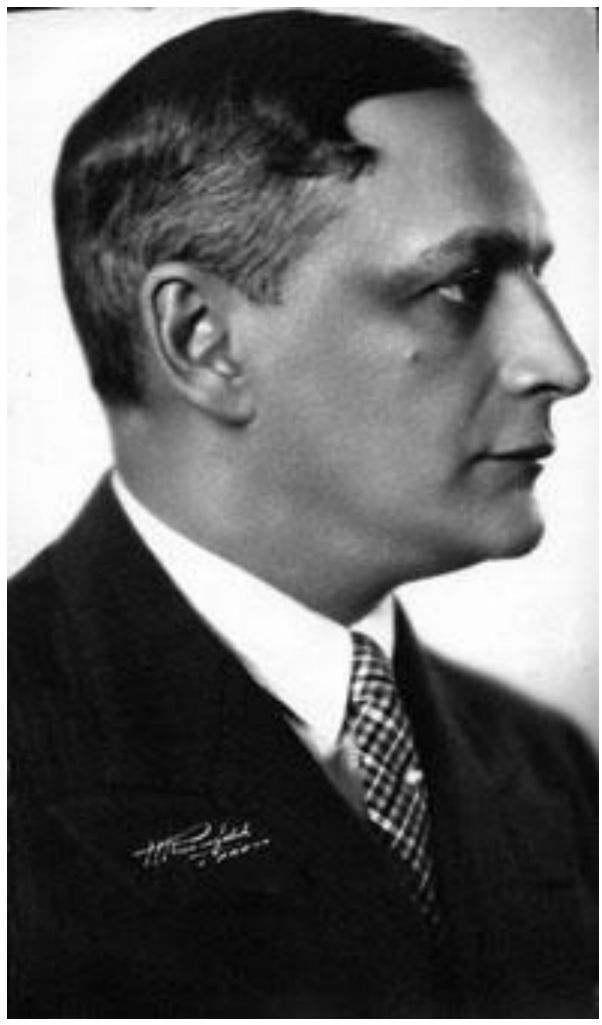

Imagem 17: Roberto Cochrane Simonsen, sem data. Fonte: Acervo Digital USP.

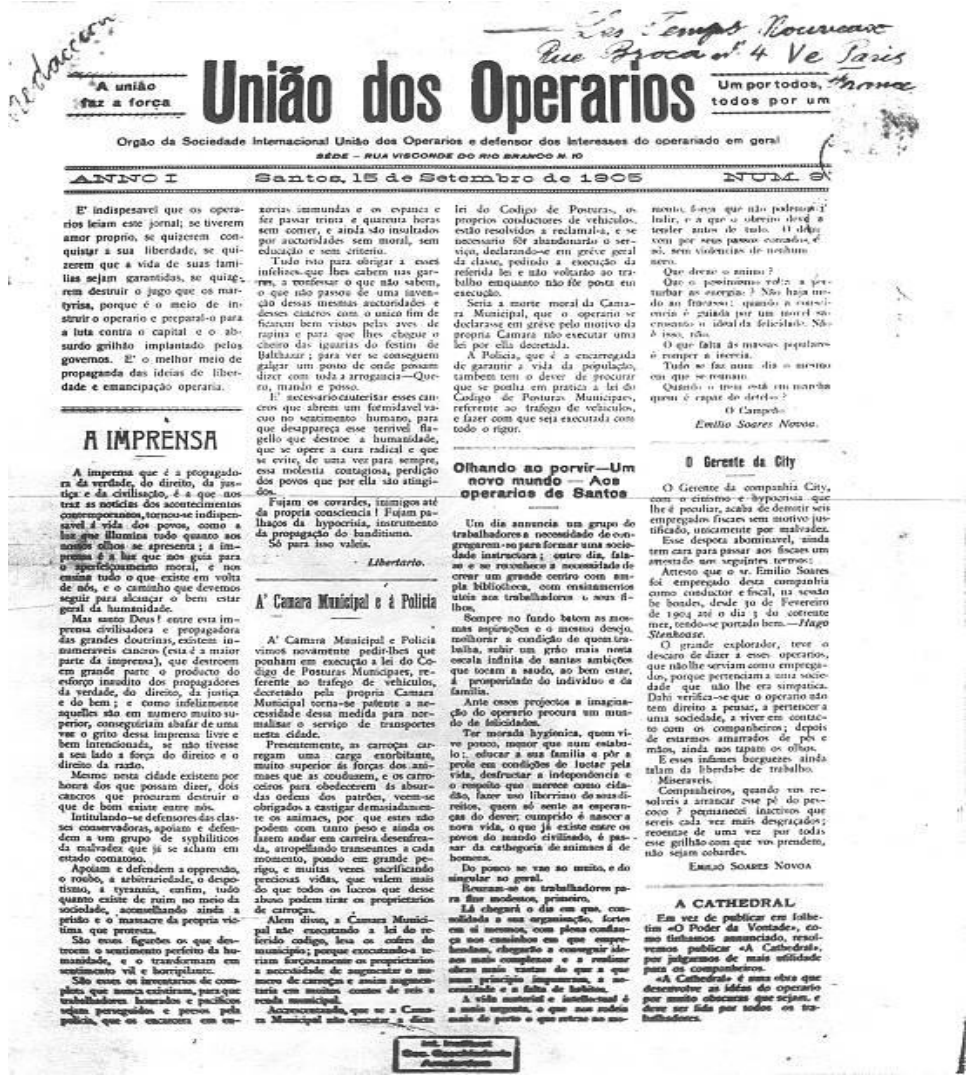

Imagem 18: Jornal União dos Operários, 15 de Setembro de 1905. Fonte: Arquivo Público do Estado de São Paulo. 


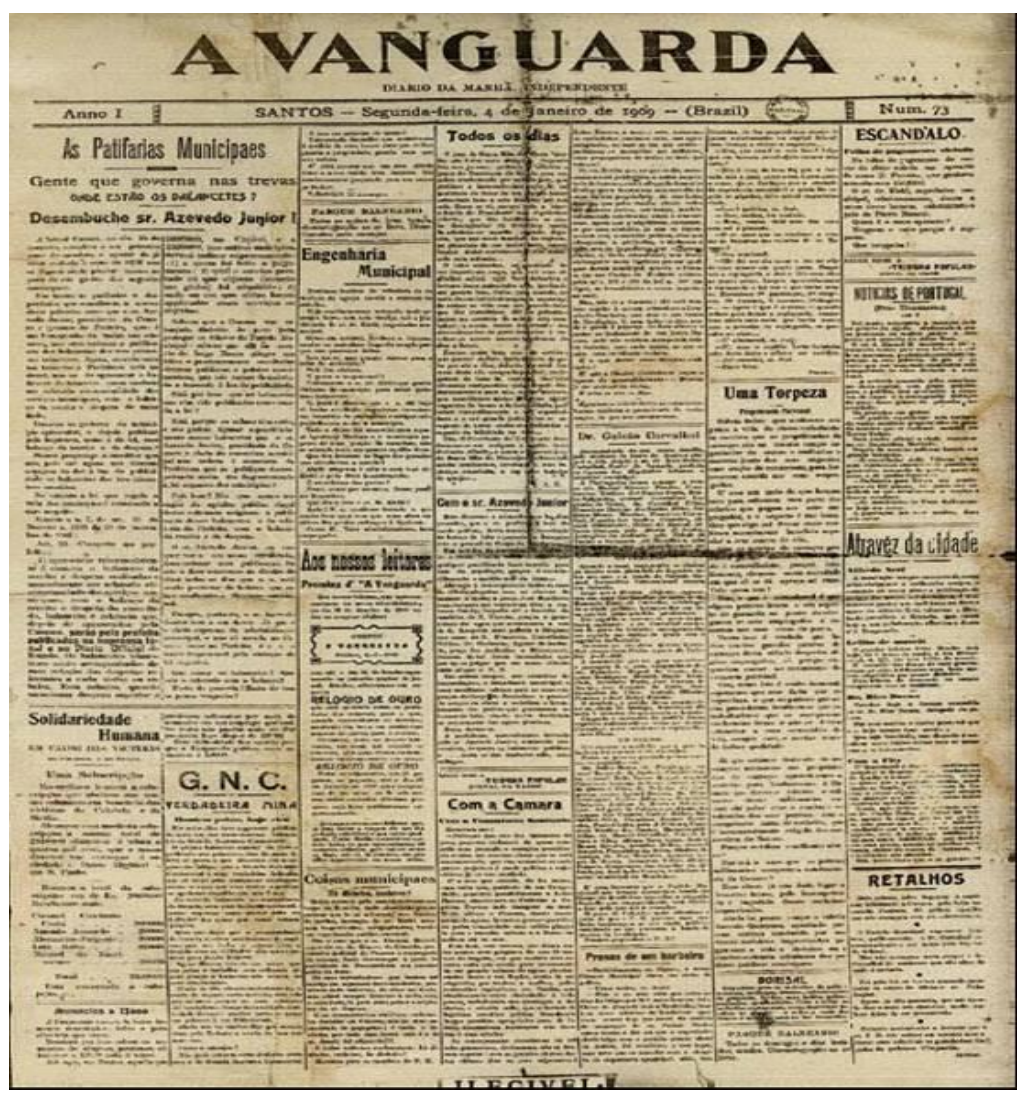

Imagem 19: Jornal A Vanguarda, 04 de Janeiro de 1909. Fonte: Arquivo Público do Estado de São Paulo.

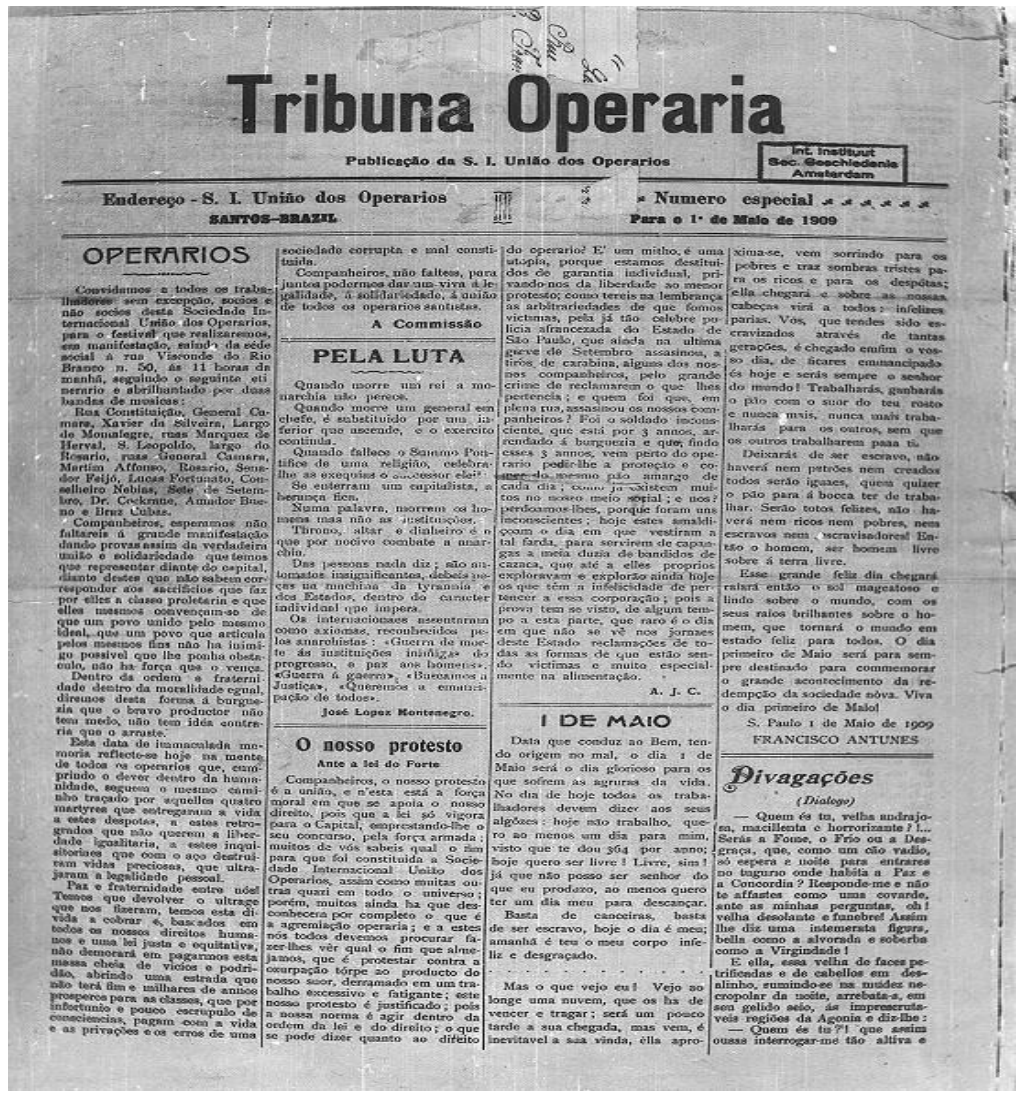

Imagem 20: Jornal A Tribuna Operária, 01 de Maio de 1909. Fonte: Arquivo Público do Estado de São Paulo. 


\section{AURORA SOCIAL}

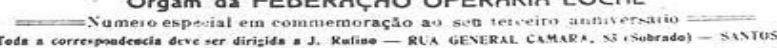

\section{Aurora Social} Completa hoje o seu terceiro ammiver-
sario a nossa modesta folha. Quando a tres annos iniciansss a sua puthicasio, era nossa intencrito publica-la yelo menos sema-
nalmiente. Or grandes embarasos e ogran. nalmente Os grandes embarasos e o gran.
le numero de tudas que a oroquizasto te. of que sustentar, impedio que se realisasse beica-la turrate tres a conseguimos le, auxilizados por nit poqueno nutwero do camminatas dericarion

Eutrelinto ainta nso perdeuros a es

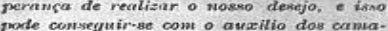
radas que reconhecem ntil e necessaria sиа puslicrsió.

Que é necessaria a publicasao de $\mathrm{nm}$ jomal nusko, esta fora de qualquer duvide tu imperiona, a obra que uin jornal pode rea. lisar é grande e toda a contribuista que

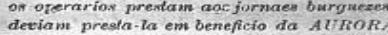
deviam presta-la em beneficio da ALTORA
SOCIAL procurando dar-lie vida prospera para que ella seja o echo constante das nos. sas asyirasier, o jornal abthe ris a maioria dos operarios a discretir os assumplos que se relacionam com a zropria can

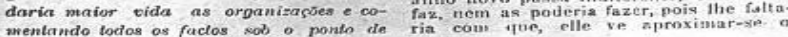

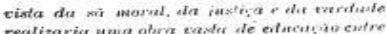
oprotetariendo.

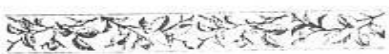
ANNO NOVO

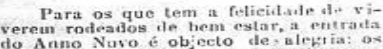

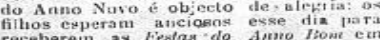

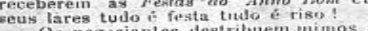

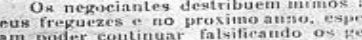

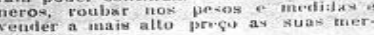

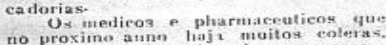

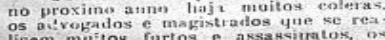

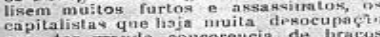

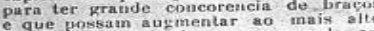
preco os alugueis das cazas. o padre e
pera que tio noro anno morra muits te to para dizer missos em quantividade sanguessugas outra couza nato expersith

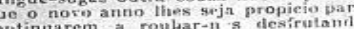

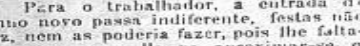

Imagem 21: Jornal Aurora Social, 14 de Julho de 1910. Fonte: Arquivo Público do Estado de São Paulo.

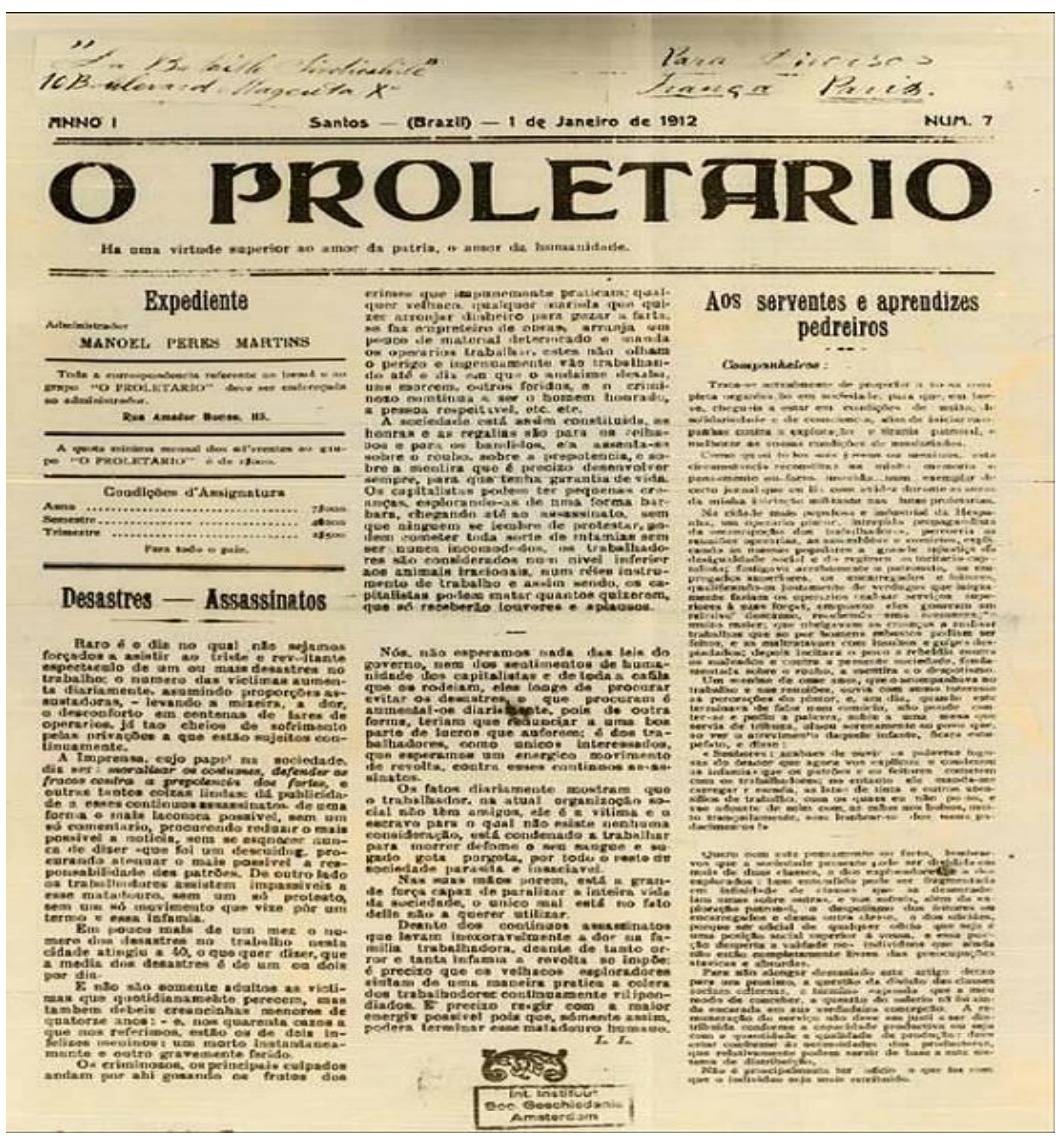

Imagem 22: Jornal O Proletário, 01 de Janeiro, de 1912. Fonte: Arquivo Público do Estado de São Paulo. 


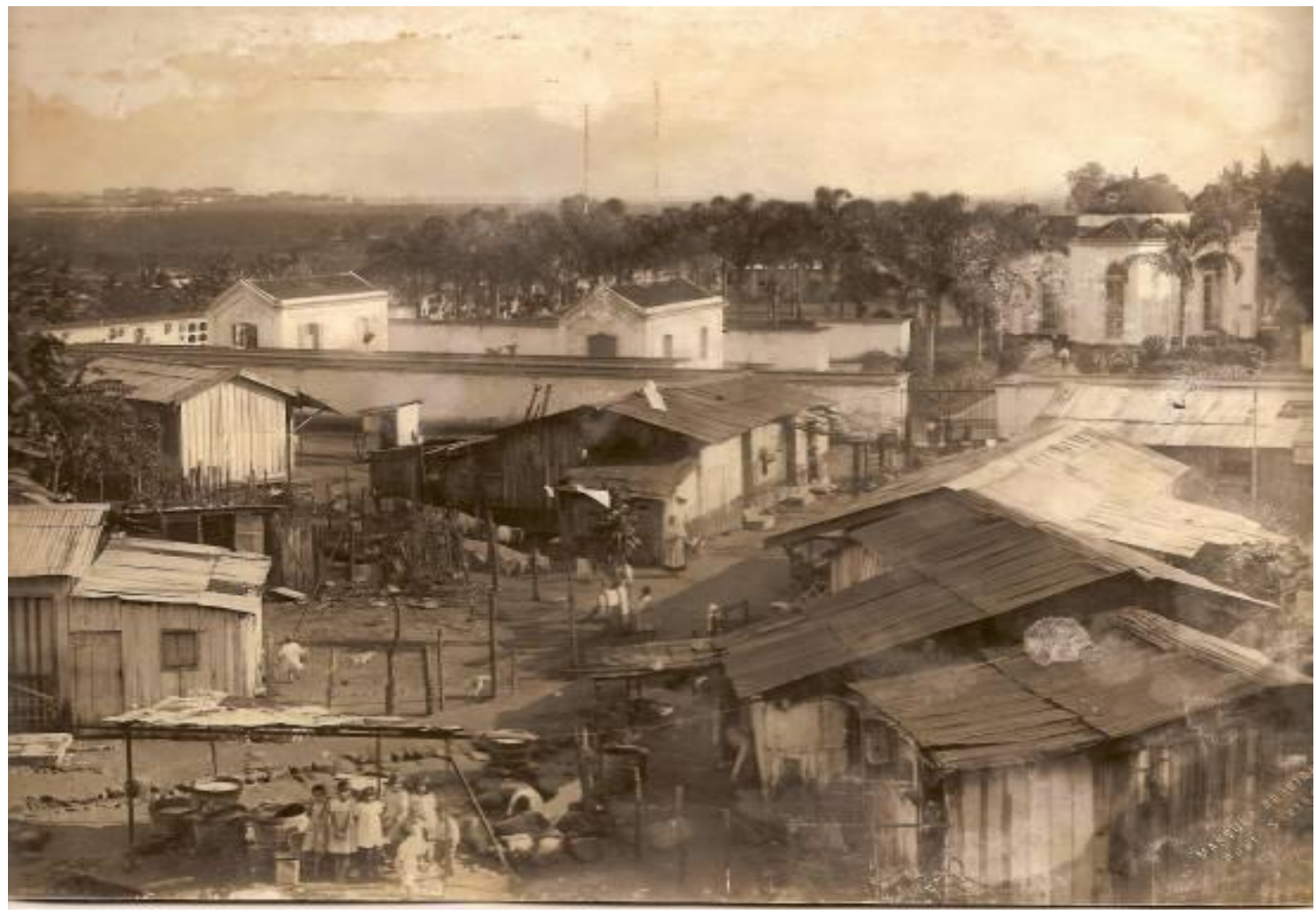

Imagem 23: Chalés de Madeira no Bairro do Saboó, 1920. Fonte: Fundação Arquivo e Memória de Santos.

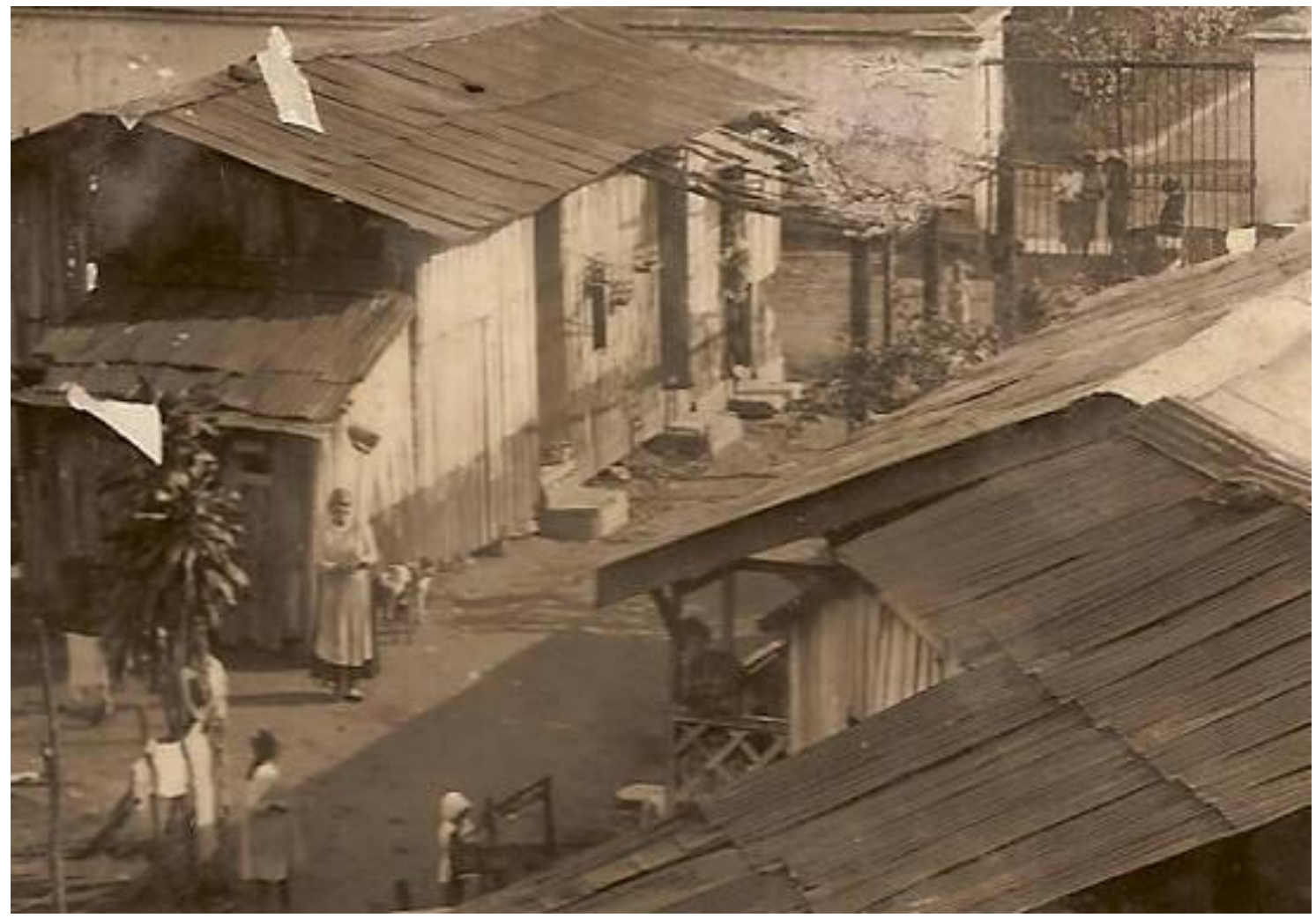

Imagem 24: Chalés de Madeira no Bairro do Saboó, 1920. Fonte: Fundação Arquivo e Memória de Santos (Detalhamento da imagem anterior) 


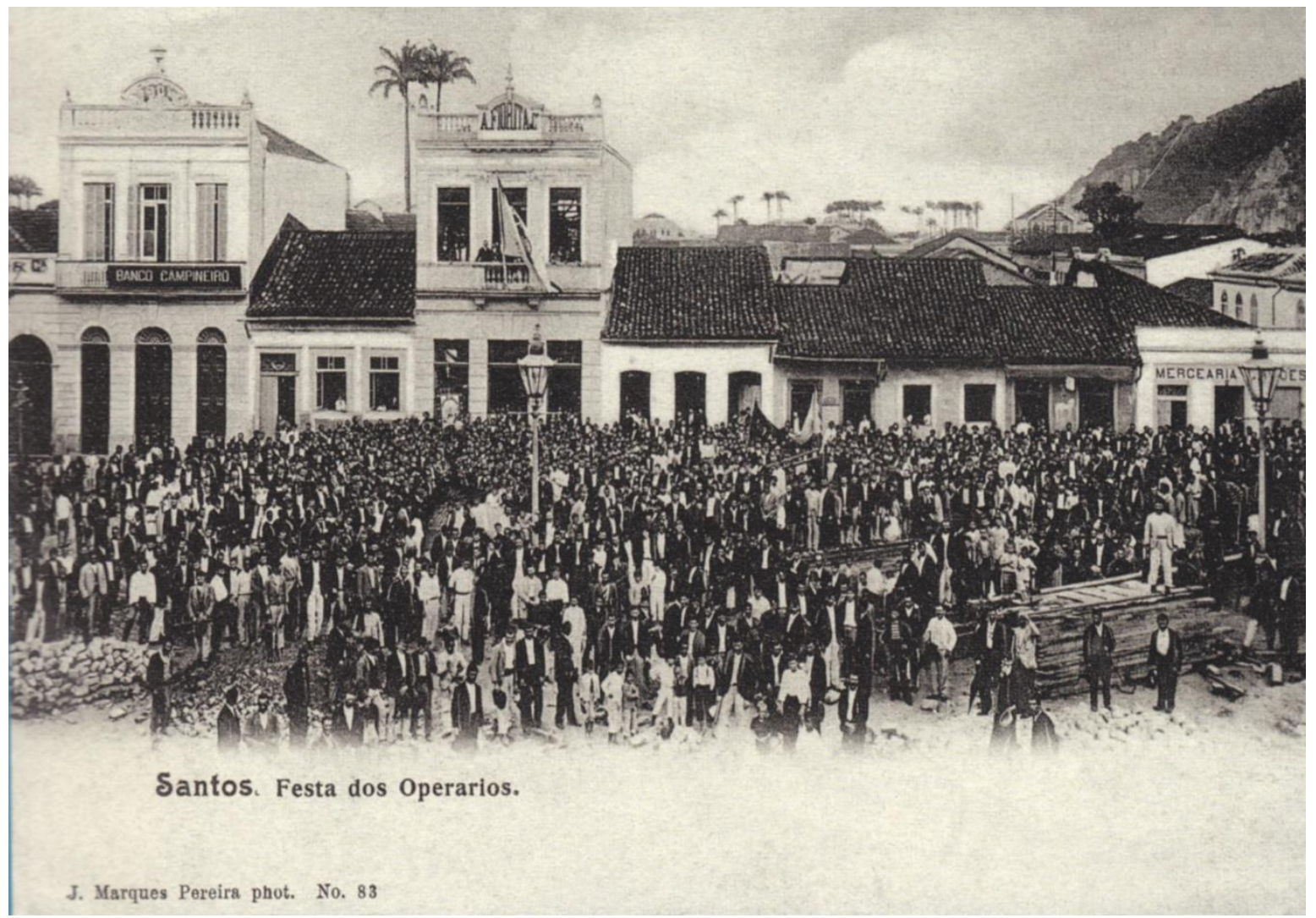

Imagem 25: Festa de Operários, 1909. Fonte: Fundação Arquivo e Memória de Santos. 
Capítulo 3: A bola rola nos caminhos da cidade: o futebol santista no alvorecer do século XX 
"O futebol dos grupos subalternos tornava-se um modo de representação da existência negada em outros campos sociais. (...) Havia, então, dupla concepção de futebol. De uma parte, estava a perspectiva pedagógica européia. Harmonia dos músculos, higienização dos corpos, etiqueta, coordenação dos movimentos e controle da violência seriam elementos a contribuir para o fortalecimento moral dos futuros dirigentes do país. De outra parte, estava a realidade nacional dos corpos adestrados no trabalho braçal e habituados aos folguedos das danças populares e a toda sorte de improvisações vinculadas ao mundo do trabalho e a precárias condições de vida."

(Hilário Franco Jr., A Dança dos Deuses, 2007) 
Na cidade que se configurava, os sports seriam elementos indissociáveis da ideia de modernidade que se pretendia instaurar e da marca de progresso que se pretendia imprimir. A cidade capitalista, como apontado por Mascarenhas (2014), é um espaço de confrontos. Os trabalhadores, ao longo da história, formataram diversas estratégias de organização e embates diante do processo de formação da sociedade burguesa. Tais estratégias incluem a apropriação cotidiana dos espaços para satisfazer necessidades diversas, da sobrevivência material imediata ao lazer e à sociabilidade.

Foi assim que o futebol, prática social inicialmente formatada no seio das elites e difundida rapidamente como indústria do espetáculo (portanto, inserida no circuito de acumulação), conquistou as periferias urbanas e os segmentos mais empobrecidos da população.

Nesse terceiro e último capítulo, analisaremos a rápida apropriação de práticas esportivas - o futebol, especialmente -, inicialmente elitizadas e concebidas como elementos de distinção de classe, pela população pobre e trabalhadora da cidade. Procuraremos demonstrar que o futebol não foi conseqüência e sim parte constituinte do processo de transformação urbana de Santos nos primeiros anos do século passado.

\subsection{As elites e os sports: práticas e espaços de distinção}

\footnotetext{
"Por iniciativa de um grupo de rapazes, tendo à frente o jovem Henrique Porchat de Assis (Dick Martins), teve lugar na Praia da Barra um training de football que foi o primeiro a ser realizado não só nesta cidade como em todo o litoral paulista. A tentativa aprovou em cheio. É um divertimento que, em se o amparando, dar-nos-á em glórias, tudo".
}

Com essa breve nota, publicada no dia 02 de novembro de 1902, o jornal A Tribuna descrevia a primeira partida de futebol de que se tem notícia na cidade de Santos.

Na transição do século XIX para o século XX, uma enorme variedade de atividades dedicadas ao lazer passa a ocupar as páginas dos dois jornais comerciais de maior circulação na cidade de Santos, A Tribuna e o Diário de Santos. Os bailes, promovidos principalmente por jovens da elite local através de sociedades carnavalescas e clubes criados nas últimas décadas 
do século XIX, o footing à beira-mar, o teatro, o cinema e práticas esportivas como o ciclismo e o remo figuravam com destaque nos periódicos locais.

Nessa época, diversas atividades esportivas começavam a mobilizar pequenas multidões nas maiores cidades do país. Ao esporte associava-se certa idéia de disciplina, saúde, dinamismo e conhecimento do corpo e de suas capacidades. Em estudo sobre cultura urbana na Primeira República, José Geraldo Vinci de Moraes aponta que:

\footnotetext{
"como grande parte das modalidades esportivas introduzidas no país na passagem do século eram importadas da Europa, era considerado de "bomgosto" praticar algum tipo de esporte. Assim, o homem moderno, principalmente os jovens, educados de acordo com os princípios "civilizatórios", deveria praticá-los com certa regularidade. Por isso, no começo do século, a maioria das atividades esportivas era realizada por membros da elite que perseguiam o "estilo de vida moderno". (...) Para cada atividade que surgia, era necessário um espaço específico no centro urbano, como rios e lagos, velódromos, campos abertos, estádios, quadras fechadas. As ruas eram também ocupadas com manifestações esportivas públicas. As cidades mobilizavam-se ainda mais com as inúmeras atividades esportivas e, por causa delas, aumentava-se o clima de agitação urbana." (MORAES, 1994, p. 92-93)
}

Esse processo pode ser visto, por um lado, como a generalização de uma percepção de lazer como consumo do tempo livre e de consolidação dos valores burgueses de fruição do tempo. Por outro lado, como um processo que parece ser para todos, mas que vai criando espaços de distinção, como indica Hobsbawm (1987) ao afirmar que a consolidação das classes sociais e de suas identidades percorre não apenas as esferas diretamente vinculadas ao trabalho, mas também a criação de símbolos e de atividades (inclusive lúdicas) distintivas. 0 aparecimento dos esportes modernos na Europa foi um fenômeno tipicamente burguês da segunda metade do século XIX. Os jogos entre equipes que se confrontavam em igualdade de condições foram incorporados ao modo de viver dessa classe. Eles ultrapassaram os muros das escolas e se espalharam como manias típicas do comportamento urbano moderno. Como indica Gambeta (2013, p. 22), o "lazer esportivo virou marca de distinção para os moços da nata burguesa, os sportsmen das elites locais".

A prática dos sports europeus, mormente aqueles de origem britânica, está inserida, portanto, dentro de uma lógica muito mais ampla de adoção de práticas culturais, sanitárias - 
explicitadas pelas grandes reformas urbanas durante a Primeira República - e de sociabilidade (PRIORE \& MELO, 2005). O esporte moderno, nesse sentido, ganhou entre tais segmentos sociais status de prática "civilizada", conceito pensado aqui na chave desenvolvida pelo já citado Norbert Elias (1990). O esporte - entre outras práticas - ganhou significação de elemento de expressão e posicionamento social ligado à modernidade europeia, parte de uma preocupação eugênica com a constituição de um novo modelo de homem brasileiro, com novas preocupações estéticas e corporais, como aponta Victor Andrade de Melo (2001, p. 51).

Nesse contexto, a análise do processo de formação dos clubes esportivos precisa levar em conta a complexidade dessas instituições, cuja importância não está apenas nos esportes nelas praticados, mas no espaço de sociabilidade criado e nelas forjado. Na visão de Wilson Gambeta, "uma atividade cultural importada só se incorpora efetivamente quando a sociedade receptora a decodifica e atribui sentido social a sua simbologia - para praticantes e espectadores - ainda que seja através de ressignificações" (GAMBETA, 2013, p. 124). Ainda de acordo com Gambeta, a prática do futebol em São Paulo na virada do século XIX para o XX dividia espaço dentro dos clubes com outras modalidades, apontando para uma grande diversidade esportiva nos anos iniciais da República (Idem, p. 126):

\footnotetext{
“Não procede a ideia de que o futebol atraiu público numeroso logo após a sua chegada ou que um gosto natural pelos jogos de chutar bola tenha desencadeado a construção estádios para acomodar às platéias que se reuniam espontaneamente. $\mathrm{O}$ futebol só se tornou a principal atração esportiva alguns anos depois, por escolha da elite dirigente. Os clubes fundados em São Paulo entre os últimos anos do Império e a primeira década de República eram poliesportivos, mesclavam exercícios ginásticos, disputas individuais e jogos entre equipes."
}

Embora circunscrito ao caso paulistano, o texto de Gambeta encontraria correspondência em Santos. Inicialmente, a influência britânica na cidade era marcante.

Arquétipos de uma espécie de migração ideal, pelo menos na ótica do governo republicano, a presença de britânicos no país estava atrelada, em larga medida, à chegada de empresas de comércio exterior, transportes, serviços urbanos e bancos - partícipes fundamentais do processo de modernização pretendido pela República - gerando, além de reconfigurações econômicas e da malha urbana, mudança de hábitos (SEVCENKO, 2010). A dinâmica interna dessas recém-formadas comunidades estrangeiras nas cidades favorecia a 
reprodução de práticas sociais do país de origem. Um círculo de sociabilidade formado a partir do elemento lúdico e do esporte era uma presumível forma de associação (FRANCO JR, 2007).

A fundação do Santos Athletic Club, mais conhecido como Clube dos Ingleses (ver imagens 7 e 8, p. 137), em 1889, deixaria marca indelével na difusão de práticas esportivas na Santos do início da República. Fundado por funcionários da City, da São Paulo Railway e por funcionários de empresas britânicas sediadas em Santos, o clube surgiu com a proposta de regulamentar e organizar as partidas de cricket (ver imagem 5, p. 136) disputadas por ingleses nas praias da cidade. Por iniciativa do australiano Alexander Kealman, corretor de câmbio, jovens de origem britânica reuniram-se nos escritórios da firma exportadora de café Naumann Gepp \& Co. e lá elegeram a primeira diretoria do Santos Athletic Club, no dia 15 de agosto de 1889. Esta diretoria era composta pelo presidente, W. Ellis; vice-presidente W. S. Baillie; secretário, A. Miller; tesoureiro: A. Sell, e os diretores: J.W. Kempster, E.U. Broad e C.H. Tross. Alguns desses nomes fariam parte da gênese do futebol santista, como veremos mais adiante.

Embora restrito a membros de nacionalidade britânica - o clube permitiria sócios de outras nacionalidades e origens apenas na década de 1940 -, o clube abria suas portas anualmente para a realização de um grande evento, conhecido como "Sportiva Annual" (ver imagem 6, p. 136). O primeiro registro encontrado na imprensa local, datado de 08 de novembro de 1898, nos fornece interessantes informações ao afirmar que:

\footnotetext{
"Os membros da colônia inglesa realizaram vultuoso encontro em suas dependências. O campo estava todo decorado com bandeiras, e uma enorme tenda estava disposta ao lado dele, onde se instalava um serviço de buffet para os convidados. Marinheiros e oficiais de divisão naval que se encontravam no porto dirigiram-se ao clube, onde eram recebidos ao som do hino inglês". (A TRIBUNA, 08/11/1898)
}

Anos depois, a mesma A Tribuna, em reportagem comemorativa de 1939, traria uma descrição mais detalhada dos eventos promovidos pelos sócios do clube em fins do XIX. Segundo a reportagem:

"O evento conhecido como Sportiva Annual era ansiosamente aguardado pela sociedade santista. Organizavam-se provas esportivas para participarem do evento. Entre as provas de atletismo disputadas no Campo dos Ingleses encontramos salto a distância, o salto em altura, arremesso de peso, corrida de bicicleta, corrida de $1 / 4$ de milha, prova dos 200 e 120 
metros, além de provas para crianças, como a corrida das meninas e a corrida dos garotos. Eram ainda organizadas provas como a corrida do saco, cabo de guerra, corrida de três pernas e a corrida do burro. De todas as provas, a mais esperada era sem dúvida a Challenge Cup do Jards Flat Race, corrida de cavalos realizada na praia em que o ganhador levava para casa o Corpo de Ouro" (A TRIBUNA, 26/01/1939)

O esporte que se praticava e o lugar onde se exercitava indicavam as distinções sociais que recortavam a cidade e a sociedade. Veículos sedutores de promessas libertadoras e civilizatórias, os esportes traziam em si uma concepção, embora difusa, de modernidade e progresso. Os clubes esportivos, como outras instituições formais da elite, expressavam, mesmo que de forma ritualizada, certa visão de mundo e certos padrões de dominação social (NEEDELL, 1993, p. 99).

Ainda segundo o mesmo autor, em estudo sobre as elites cariocas durante a belle époque, a:

\footnotetext{
“elite brasileira, na transição do século XIX para o século XX, manteve e continuou promovendo inalterados os seus interesses mediante a construção de um sentido de continuidade aristocrática, estabelecendo lugares de encontros exclusivos para os seus contatos e alianças e para o reforço de valores supostamente compartilhados. Acima de tudo - e esse é provavelmente o fator mais importante - buscava-se um sentido de legitimidade, em um contexto de profundas metamorfoses econômicas, políticas e sociais." (NEEDELL, 1993, p. 53)
}

Nesses ambientes, a simbologia do "atleta", do "velocista" e, futuramente, do "craque", enfim, dos sportsmen como modelo a ser emulado produzia um reforço de classe, de práticas ditas modernas e distintivas, já que excludentes.

O futebol na cidade de Santos, tardio em relação ao ciclismo (ver imagem 9, p. 138) e os esportes náuticos (ver imagens 10 e 11, p. 138-139) (VIEIRA, 2010, p. 92), guardava em si, pelo menos nos primeiros anos após sua implementação, a dimensão simbólica de atividade portadora de benefícios incontestes por ser oriundo das "mais avançadas" civilizações europeias.

Codificado pelos ingleses em 1863, o futebol, em linhas gerais, pouco se modificou desde sua onda de difusão mundial ocorrida a partir de 1890. Em expressão cunhada pelo 
geógrafo Gilmar Mascarenhas (1999, p. 25), o futebol seria, rapidamente, o "mais duradouro, disseminado e bem-sucedido produto de exportação da Inglaterra vitoriana", grande potência mundial do século XIX. Desnecessário seria argumentar sobre o imenso poderio da Inglaterra na segunda metade do século XIX. Essa quase onipresença da civilização britânica pelo mundo favoreceu amplamente a difusão dos esportes modernos por ela engendrados. Os milhares de ingleses que migraram para trabalhar em outros países, seja no setor de mercado interno (ferrovias, empresas de serviços urbanos), seja em fábricas ou em minas, sejam os muitos marinheiros espalhados pelos portos mundo afora, contribuíram direta (através da criação de clubes, escolas e associações) ou indiretamente (através da prática do esporte observada e, em alguns casos, copiada pelos locais) para a disseminação do association football (Mascarenhas, 2002, p. 40). A propagação planetária do futebol está intrinsecamente relacionada ao imperialismo inglês e à sua vasta área de influência. Surgido no seio das elitizadas instituições de ensino da Inglaterra e rapidamente popularizado pela classe operária britânica, o futebol moderno é fruto do acelerado processo de urbanização ocorrido no país no final do século XIX no contexto da Segunda Revolução Industrial. A "religião leiga da classe operária", nas palavras de Hobsbawm (1987, p. 262), se espalhava pelo mundo. Não demoraria a marcar presença nas areias e, posteriormente, nas ruas e gramados da cidade de Santos.

\subsection{O futebol na cidade de Santos: gênese e intersecções}

Em crônica publicada em 1952 sobre a gênese do futebol santista, o jornalista Adriano Neiva da Motta e Silva, famoso sob a alcunha De Vaney, nos oferece interessante abordagem sobre a percepção civilizadora que o futebol possuía para parte da juventude abastada de Santos no início do século. De Vaney descreve as reuniões que antecederam a primeira partida nas areias da Praia da Barra (hoje praia do Boqueirão) como iniciativa de Henrique Porchat de Assis, "baluarte do ciclismo" e conhecido como Dick Martins. Filho do belga Henry Porchat (militante abolicionista e um dos fundadores do Núcleo Republicano de Santos), Henrique Porchat de Assis era vereador na cidade de Santos no período.

Ainda segundo o jornalista, Dick Martins teria reunido um grupo de jovens amigos no teatro Variedades, ponto de encontro de membros da elite local. Em tom melancólico, Porchat de Assis teria dito aos presentes que Santos estaria "atrasada" em relação a São Paulo, Rio de Janeiro e outras cidades importantes do Brasil pelo desconhecimento do esporte bretão que seria a nova febre no planalto. A reunião, realizada na segunda quinzena de setembro de 1902, terminaria em festa regada ao chopp do tradicional bar Tivoli e daria início aos preparativos 
para a partida que seria considerada a primeira já realizada na cidade. Os presentes se comprometeram a colaborar financeiramente para a aquisição de duas bolas, compradas na cidade de São Paulo por Henrique Porchat de Assis ao valor de 15 mil réis cada. Pouco mais de um mês após a reunião inicial promovida por Dick Martins, as areias da praia da Barra na altura da capela - atual Igreja - do Embaré receberiam, no dia primeiro de novembro, o primeiro match de football association da cidade de Santos.

A trajetória pessoal de Henrique Porchat de Assis é paradigmática das intersecções existentes entre as atividades lúdicas e práticas esportivas típicas da elite santista do período. Porchat de Assis era associado ao Clube XV (ver imagem 4, p. 135), entidade fundada em 1869 como dissidência da Sociedade Carnavalesca de Santos. Inicialmente dedicado exclusivamente a desfiles de carnaval e promoção de eventos sociais, o Clube XV se transforma, na década de 1890, em agremiação de caráter mais diversificado. Integrantes do clube, entre eles Porchat de Assis, fundam, em 1896, o Velo Sport Club (ver imagem 9, p. 138), clube que reunia praticantes de ciclismo da cidade. Além de Henrique Porchat de Assis, outros sócios do Clube XV e do Velo Sport Club, como Quintino Ratto, Eduardo Machado e Raul Schmidt, estariam presentes ao pontapé inicial do futebol santista em 1902. Até então, os esportes náuticos concentravam as atenções de grande parte da juventude interessada em práticas esportivas. Em 1893 havia sido fundado o Clube de Regatas Santista, primeiro clube do gênero no estado de São Paulo. Pouco depois, ainda como membro do Velo Sport Club, Henrique Porchat de Assis participaria das reuniões iniciais que dariam origem ao Clube Internacional de Regatas, fundado definitivamente em 1898. O novo clube dedicado especialmente ao remo teria como seu segundo presidente (entre 1899 e 1900) um amigo pessoal de Henrique e também sócio do Clube XV, o também vereador Theodorico de Almeida. Anos depois, Dick Martins seria não apenas o principal articulador da primeira partida de futebol realizada na cidade, mas também um dos fundadores da primeira agremiação dedicada à prática de futebol em Santos, o Clube Atlético Internacional, fundado em 1903.

Entre os pouco mais de vinte jovens presentes ao evento do dia primeiro de novembro de 1902 (ver imagem 12, p. 139), três eram vereadores da então quarta legislatura republicana em Santos: além dos já citados Henrique Porchat de Assis e Theodorico de Almeida, Gil de Souza Rodrigues exercia mandato legislativo no período. Outros como André Miller, Henrique Tross, Teodoro Joyce, Walter Grimditsch, Harold Cross e seu irmão Victor Cross eram associados e/ou membros da diretoria do Santos Athletic Club, clube originalmente fundado em 1889 por britânicos para a prática de cricket e conhecido popularmente como Clube dos Ingleses. As intersecções não param por aí e deixam claro o papel atribuído pelas elites aos 
esportes na "moderna" e "civilizada" cidade que surgia pelas mãos do saneamento e do urbanismo.

O desenvolvimento do ciclismo como esporte no final do século XIX, por exemplo, teve como locais privilegiados as avenidas Ana Costa e Conselheiro Nébias (ver imagens 1 a 3 , p. 134-135). Longas, largas e em linha reta (a avenida Conselheiro Nébias corta a cidade da região portuária às praias), as novas vias eram amplamente utilizadas por jovens da então chamada "boa sociedade" para a prática do esporte. O ciclismo aparecia como "símbolo da tecnologia industrial, como elemento constituinte da vida no meio urbano" (GAMBETA, 2013, p. 82).

Remo, ciclismo, cricket e, enfim, o futebol. Na moderna cidade - concepção essa tomada de Marshall Berman (1986) como espaço formado por grandes contrastes materiais, condições de vida e pela emergência até então inédita das multidões - que se configurava, a progressiva aceitação do futebol insere-se nessa onda de adesão a uma vida supostamente sã e atlética. Chancelado pelas elites pretensamente cosmopolitas, o futebol adquire, então, outros conteúdos simbólicos. Cria-se um "casamento entre o futebol e o progresso, o futebol e a necessária modernidade" (MASCARENHAS, 2014, p. 84).

Pouco depois da realização, em 1902, da primeira partida registrada pelos veículos locais de imprensa santista, já em janeiro do ano seguinte, surgiria o primeiro time de futebol da cidade de Santos. O Clube Atlético Internacional (ver imagem 14, p. 140), fundado oficialmente em 06 de janeiro de 1903, surgiu por iniciativa de Henrique Porchat de Assis e de sócios do Clube XV e Velo Sport Club. O pioneiro clube contava em seus quadros iniciais com jovens estrangeiros ou filhos de imigrantes, quase todos eles britânicos. Vários deles, já citados, eram associados ao Santos Athletic Club, entidade que mais tarde, em fins da década de 1900, teria seu próprio time de futebol. A escalação da equipe na primeira partida realizada pelo Internacional contra uma equipe paulistana - combinado que reunia jogadores principalmente do C.A. Ypiranga - indica essa tendência. O Internacional entrou em campo no dia 15 de março de 1903, segundo reportagem do dia seguinte no jornal A Tribuna com: J. Thompson, Walter Grimditsch e Trail; André Miller, Joyce e Cox; Charles Murray, Victor Cross, Marsland, Lloyd e Harold Cross.

O Internacional foi também responsável pelo surgimento do primeiro campo de futebol da cidade (ver imagem 13, p. 140). Em nota publicada no dia 15 de fevereiro de 1903, o jornal Diário de Santos informa que:

“um amplo terreno na Avenida Ana Costa, de posse dos Lima, foi arrendado por Henrique Porchat de Assis para ser utilizado como campo de futebol. 0 
espaço será utilizado para as atividades do Clube Atlético Internacional, fundado no início do presente ano e o contrato contou com a adesão dos consócios da agremiação"

Durante pouco mais de uma década, o campo de futebol da Avenida Ana Costa, localizado na região da Vila Mathias (no local onde hoje está a Igreja Imaculado Coração de Maria), seria o principal palco de espetáculos futebolísticos na cidade.

Convém aqui uma breve observação. A concepção de espetáculo, segundo Guy Debord (2010), se caracteriza por um conjunto de relações sociais mediadas pelas imagens. O poder do espetáculo, ainda segundo o autor, está pulverizado pela vida social, com imagens produzidas para justificar, reafirmar, enfim, reforçar o poder das classes dirigentes. No caso de Santos, os espetáculos de futebol dos primeiros anos dos 1900, assim como as disputas ciclísticas e náuticas, serviam como espécie de mediação entre setores da elite local e as classes subalternas. A cobertura dos jornais comerciais sobre os espetáculos futebolísticos invariavelmente recaía sobre o aspecto distintivo da prática esportiva até então elitizada. Em nota sobre partida disputada pelo Internacional em abril de 1904, por exemplo, A Tribuna enfatizava a presença ao local de "público composto por algumas das melhores famílias de nossa sociedade". O futebol, herdeiro de outros esportes de espetáculo, crescia, paulatinamente, como fruto de relações sociais e processos históricos há muito em desenvolvimento.

Em cada cidade, os primeiros praticantes do futebol buscavam superar o isolamento e incentivar a adesão de novos praticantes. Em Santos, o surgimento de uma segunda equipe não tardou a acontecer. Em 22 de maio de 1903, o jornal $A$ Tribuna noticiava a fundação, ocorrida no dia anterior, do Sport Club Americano. Sem entrar em maiores detalhes, o periódico indica que o novo clube provinha de uma cisão entre integrantes do até então único clube da cidade, o Internacional. A reunião de fundação foi realizada na casa do então presidente da Câmara Municipal de Santos, Américo Martins dos Santos, por iniciativa de seu filho, Américo Martins Junior.

Surgia o primeiro derby santista: Clube Atlético Internacional X Sport Club Americano.

Os pioneiros do futebol de Santos teriam vida marcante, porém breve. Ambos participariam, a partir de seletivas disputadas já em 1904 pelo Internacional, dos campeonatos paulistas promovidos pela Liga Paulista de Futebol durante a década de 1900. O Internacional permaneceria em atividade até 1910. O Americano, após participações destacadas no torneio estadual - o clube foi vice-campeão nos anos de 1910 e 1911 - transferiria sua sede para a 
cidade de São Paulo em fins de 1911, sendo campeão paulista nos dois anos subseqüentes antes do término definitivo de suas atividades em 1916.

A transferência do Sport Club Americano para São Paulo acabaria sendo decisiva para os rumos do futebol santista e para a fundação do clube que rapidamente se tornaria o mais popular da cidade. A cisão provocada pela decisão de parte dos associados de levar o clube para o planalto provocou o surgimento, em 1912, do Santos Futebol Clube.

\subsection{Santos Football Club: rivalidades e a construção da hegemonia do "time da cidade"}

A fundação de uma nova agremiação na cidade havia sido prenunciada na imprensa local através de anúncio publicado em O Diário de Santos no dia 09 de abril de 1912. Segundo a nota:

\footnotetext{
"vários sportsmen desta cidade estão empenhados em organizar um poderoso club de football. É já sensível entre nós a ausência de um bom clube dedicado ao bello sport de football. Acreditamos que o novo clube venha preencher essa lacuna."
}

Antes mesmo de sua fundação, o novo clube já possuía um vasto espaço à sua disposição. O mesmo anúncio do dia 09 de abril anunciava a concessão de "esplêndido terreno de propriedade de José Domingues Martins, à Rua Aguiar de Andrade, no Macuco".

O surgimento do Santos Futebol Clube seria verdadeiro ponto de inflexão no processo de disseminação e popularização do esporte na cidade de Santos. Por um lado, fundado e dirigido por elementos do alto comércio local. Por outro lado, seguido de perto por profissionais liberais, empregados do comércio, estudantes e trabalhadores de diversos segmentos.

Vejamos alguns exemplos: José Domingues Martins, dono do terreno concedido ao clube no bairro do Macuco, era comissário de café, havia sido presidente da Associação Comercial de Santos, vereador e presidente da Câmara Municipal de Santos nos últimos anos da década de 1900. Sizino Collatino Martins Patusca, aclamado como primeiro presidente do clube após sua fundação definitiva ocorrida no dia 14 de abril de 1912, era filho de um dos fundadores da Associação Comercial de Santos, Manuel José Martins Patusca. Sizino, que também havia sido presidente do Clube Éden Santista, dissidência do Clube XV e voltado para 
atividades culturais e carnavalescas, era um dos diretores da Patusca \& Filho, empresa do ramo de sal sediada na Praça dos Andradas, centro da cidade. Sizino havia sido também, uma década antes, um dos fundadores do Sport Club Americano. Antonio Iguatemi Martins Júnior, um dos fundadores, era filho de Antonio Iguatemi Martins, presidente da Associação Comercial e da Câmara Municipal de Santos nos últimos anos do século XIX. Ele próprio seria prefeito de Santos na segunda metade da década de 1930. A edição do jornal A Tribuna do dia 15 de abril de 1912, dia seguinte ao ato de fundação do clube, enfatizava que "acaba de ser fundado nesta cidade um clube de football destinado, por certo, a uma vida longa e plena de vitórias, para o que conta com os melhores elementos desta terra".

Se, por um lado, os fundadores e primeiros dirigentes do clube estavam majoritariamente vinculados ao grande comércio e/ou à política local, por outro lado, os seus primeiros sócios apresentavam características mais variadas. A análise das listas de sócios nos primeiros cinco anos da história do clube - disponíveis para consulta no centro de memória localizado na sede do clube - indica o predomínio de jovens - as fichas de filiação não apresentam data de nascimento, mas quase todos eram solteiros - empregados do comércio e do setor de transportes. Alguns poucos estudantes e profissionais liberais como professores e médicos e muitos trabalhadores de atividades vinculadas essencialmente ao porto e/ou café. Havia predomínio de moradores da região central da cidade e adjacências, como a Vila Mathias e o Macuco. Essas regiões, como já discutido no capítulo anterior, eram ocupadas majoritariamente por trabalhadores, especialmente vinculados à atividade portuária, à construção civil e demais serviços urbanos.

A primeira partida oficial realizada pelo recém-fundado Santos Football-Club (ver imagem 15, p. 141) foi descrita nesses termos pelo jornal Diário de Santos no dia 16 de setembro de 1912:

\footnotetext{
"em redor do field, achavam-se as mais distinctas famílias inglezas e brasileiras. Comentava-se a quem caberia a victoria, uns opinavam pelos inglezes, outros pelos brasileiros. Os presentes, ao final do match, aplaudiam efusivamente os brasileiros, dignos representantes locais do jogo de foot-ball."
}

A descrição da peleja, vencida por 3X2 pelos "brasileiros" contra o chamado "Clube dos Ingleses", indica uma interessante tendência que permaneceria forte nos anos subseqüentes. 
O "poderoso club de football", nas linhas do Diário de Santos em abril de 1912, adquiria, rapidamente, o status de "time da cidade". Na imprensa comercial de maior circulação, a construção de uma narrativa que parecia reeditar a tradicional contenda entre o localismo santista e as interferências externas - ora representadas por estrangeiros, ora representadas pelo planalto, ora representadas pelos governos da União e Estado.

Pouco menos de dois meses depois, a pedido do Clube dos Ingleses, os dois se times enfrentariam novamente. Em "anunciado match entre as valorosas equipes do Santos FootBall Club e do Scratch Inglez", conforme noticiou o jornal Diário de Santos de 11 de novembro de 1912, o Santos F.C. terminou a partida novamente em vantagem, desta vez por $1 \times 0$. A imprensa, ao destacar a boa atuação do sistema defensivo do Santos Football Club, evidenciava mais uma vez a oposição entre "brasileiros" e "inglezes":

\footnotetext{
“Começando o segundo tempo, os inglezes atacaram vigorosamente, porém sem resultado devido aos back do Santos que oppuzeram intransponivel obstáculo aos seus competidores, sahindo o scratch local vencedor por 1 a 0. Mais uma vez, os brasileiros saíam vitoriosos sob aplausos dos seus e descontentamento dos estrangeiros." (Diário de Santos, 11/11/1912)
}

A ênfase aqui recai não apenas no reforço da oposição entre "brasileiros" e "estrangeiros". A cobertura da imprensa santista nos primeiros anos de existência do Santos Football Club seria marcada pela constante reafirmação do clube como ente essencialmente local. É como se, no campo do simbólico - representado agora pelas disputas futebolísticas estivessem reeditando as antigas contendas e rivalidades políticas entre a municipalidade - ou os ditos "interesses locais" - e as forças políticas advindas da capital do Estado.

Em meados de 1913, pouco mais de um ano após a sua fundação, o clube jogaria pela primeira vez o campeonato paulista de futebol. A participação, no entanto seria breve. Depois de participar de apenas quatro partidas, todas elas no campo do Parque Antártica, na capital, o Santos F.C. solicitou afastamento à Associação Paulista de Sports Athleticos (APSA). Em reportagem de julho do mesmo ano, o jornal $A$ Tribuna apresenta interessante explicação para o fato:

"O Santos Football Club requisitou afastamento dos certames estaduais junto à Associação Paulista de Sports Athleticos. A imposição da proibição de realizar jogos na sua cidade associada às dificuldades financeiras de se 
jogar constantemente na capital forçou a diretoria do clube a tomar tal decisão." (A Tribuna, 17/07/1913)

A "imposição" da APSA levaria o clube a abdicar também da disputa do campeonato paulista de 1914. A Associação alegava que os custos das viagens dos times da capital à Baixada Santista inviabilizariam a realização do torneio.

As dificuldades financeiras, especialmente para a realização de viagens, eram de fato uma freqüente preocupação. Um exemplo disso encontra-se registrado em ata do dia 1o de fevereiro de 1915, quando o clube recebeu convite para a disputa de um jogo na cidade de Amparo, no interior do Estado. Na ocasião, o presidente do Santos Football Club perguntou ao tesoureiro se havia "fundos suficientes em caixa para atender as despesas de viagem". Em resposta, o tesoureiro declarou que "o caixa suportará despesas que não excedam a duzentos e cinquenta mil réis". Nessa ocasião, ficou resolvido que o clube pagaria a passagem para quinze jogadores e que o grupo de sócios que acompanhariam os jogadores arcaria com suas despesas por conta própria. A diretoria comunicou então a partida dos associados do "Santos" no dia 6 do mesmo mês pelo segundo trem da manhã.

O ano de 1915 seria caracterizado por sintomático episódio das relações estabelecidas entre 0 , nas palavras frequentemente utilizadas pela imprensa local, "time de Santos" e as forças da capital - representadas aqui pelos clubes paulistanos e pela APSA.

No início do ano, o Santos F. C. solicitou, novamente, à APSA a disputa de suas partidas na Baixada Santista. Assim como no ano anterior, teve o seu pedido negado. A negativa levaria a diretoria do clube a afirmar, em ata de 14 de fevereiro, que "insistiria em jogar em sua cidade apesar da absurda proibição". A posição da diretoria, como de costume, encontrava eco na grande imprensa local. Em $O$ Diário de Santos de 02 de março, uma reportagem sobre a questão enfatizava "os absurdos privilégios concedidos pela Associação às agremiações da capital”. O clube, ao não conseguir reverter a situação, informou a Associação que disputaria o campeonato santista daquele ano, mantendo-se licenciado no certame estadual. A Associação informou o clube que ele não poderia participar do campeonato local e, caso entrasse na disputa, seria desligado da APSA. A solução encontrada pelos diretores do Santos F.C. foi a criação de um novo - e provisório - clube.

Nascia, em março de 1915, o União Football Club. As cores, os diretores e os jogadores eram os mesmos do Santos Football Club. O nome e a razão social, no entanto, eram diferentes. Com essa artimanha, o União disputaria e venceria o campeonato local de forma 
invicta com dez vitórias em dez jogos disputados. Na última partida, um sonoro $8 \times 0$ contra 0 São Paulo Railway, com seis gols de Ary Patusca.

$\mathrm{Na}$ imprensa santista, a saída encontrada pelos dirigentes santistas reforçava, mais uma vez, certa idéia de oposição entre as imposições e interferências de instâncias sediadas na capital frente aos interesses e necessidades locais. Em A Tribuna de 22 de novembro de 1915, dia posterior ao último jogo do União no campeonato santista - e último jogo da curta trajetória do recém-fundado clube - a discussão volta à baila:

\footnotetext{
"Com uma avassaladora vitória, o Santos Football Club encerra sua participação no campeonato local. Batizado forçosamente de União, o clube venceu todas as partidas do certame. (...) Espera-se agora que as restrições da Associação Paulista de Sports Athleticos não mais impeçam o time de Santos de receber os times da capital."
}

As restrições citadas na reportagem, entretanto, só cairiam com a inauguração da praça de esportes do clube, mais tarde batizada de Urbano Caldeira, em outubro de 1916. Em reunião da diretoria em 11 de outubro, é lido um ofício da APSA, "nomeando comissão que examinará o ground deste club". A mesma, em comum acordo com o Santos F.C., concordava com a transferência do match Ypiranga x Santos que deveria realizar -se no dia 12 para o dia 22 próximo. No dia 18 o Santos F.C. recebeu um ofício da APSA:

“[...] considerando o campo deste club apto para nele disputar matches do campeonato sendo de notar que esses matches serão oficiais, caso não chova copiosamente no dia do jogo ou dois dias antes e o club escalado alegue o estado do campo com as chuvas."

Em 12 de outubro, o Santos Football Club inaugurava a sua praça de esportes (ver imagem 25, p. 146) e no dia 22 do mesmo mês realizaria sua primeira partida oficial. Havia apenas modestas arquibancadas de madeira e uma cerca em volta do campo. O público pagante que assistiu à vitória do Santos sobre o Ypiranga pelo Campeonato Paulista por 2 gols a 1 foi de pouco mais de 2 mil pessoas.

O jornal A Tribuna assim retratou o acontecimento:

“É extraordinário, é ardente, o enthusiasmo que se nota entre os innumeros associados do Santos e os vários apreciadores do salutar sport britannico, 
pela grandiosa pugna que, amanhã, na nova praça de esportes, a Villa Belmiro, se vae travar entre o galhardo campeão santista e a valorosa equipe da paulicea. $O$ interesse que este encontro vem despertando em todas as rodas sportivas é a prova mais cabal da necessidade imperiosa que, desde há muito, se impunha, diante do nosso progresso sportivo, dessa extraordinária obra que um grupo de esforçados e arrojados sportsmen acaba de legar a esta cidade. Santos, presentemente, pode, affoitamente e com orgulho, dizer que, em seu seio, mantém uma praça sportiva que rivaliza com todas as congêneres do Estado. Até que enfim teremos ocasião de assistir a matches de foot -ball e não de "water -polo" e poderemos receber qualquer "esquadra" sportiva sem que tenhamos de ficar, diante dos visitantes, compromethidos e vexados, pelo desleixo e desamparo a causa sportiva. Ainda bem que esse núcleo de sportmen alcançou, após innumeros sacrifícios, a palma da victoria, que toda a população santista lhe offerta enthusiasticamente. O vasto campo do Santos ficará amanhã ao "complet" levando ali tudo quanto há de mais fidalgo no nosso Burgo. Vae, pois, ser uma das tardes superiores das nossas pugnas sportivas. $O$ valor dos antagonistas é de sobejo conhecido, e, portanto, a luta será emocionante e plena de brilhantismo. Oxalá que o tempo não venha empalidecer esta bella e grandiosa festa sportiva. De accordo com o estabelecido pela Associação Paulista de Sports Athleticos, as senhoras pagarão ingresso, e os menores de 14 annos quando acompanhados de suas famílias terão entrada franca." (A Tribuna, 21/10/1916)

A entusiasmada reportagem oferece indicações interessantes sobre o espetáculo que se formava em torno das contendas futebolísticas. As "grandiosas pugnas sportivas" eram acompanhadas por um número cada vez maior de espectadores. O estádio de "Villa Belmiro" não contava apenas com os sócios do clube e seus familiares. Se nos primeiros anos após a sua fundação era comum a disputa de partidas do Santos, como no estádio da Avenida Ana Costa, com "entrada franca", no período posterior à inauguração da praça de esportes, o número de não-sócios pagando ingressos se torna cada vez maior. Os públicos nesse período, na verdade, excediam em muito o número de sócios do clube. O Santos, por exemplo, não possuía mais do que poucas centenas de sócios no período, número obviamente incompatível com as pouco mais de duas mil pessoas presentes à partida citada. Pessoas de camadas sociais distintas, sócios e não-sócios, ainda que separadas por setores, passaram a freqüentar o estádio (ver imagens 23 e 24 , p. 145). A rápida popularização dos jogos dos clubes de futebol como 
atividade de lazer fez com que a venda de ingressos - bem mais acessível do que o valor das mensalidades - e a comercialização de produtos passassem a ser fundamentais para a normalmente combalida situação financeira destas agremiações. Sobre isso, Gabriel Pierin (2011) afirma que:

\footnotetext{
“O Santos F.C. passou a contar logo após a inauguração de sua praça de esportes com a arrecadação dos jogos e com a exploração da venda de produtos. Essa movimentação da diretoria e de comerciantes interessados começou ainda antes da inauguração, quando a Companhia Antarctica apresentou uma proposta para exploração de seus produtos no bar do clube, proposta aceita prontamente pela diretoria. O clube firmou parceria também com Francisco de Almeida, que passou a usufruir de privilégio especial para venda de balas e doces no local." (PIERIN, 2011, p. 85)
}

A construção da praça de esportes mudaria de forma significativa os rumos do Santos Football Club. O número de sócios aumentou consideravelmente (PIERIN, 2011, p. 87), assim como as receitas do clube.

A assistência, cada vez mais numerosa, acompanharia o "time da cidade" nos certames estaduais. Nos anos subseqüentes, apesar da intensa proliferação de agremiações dedicadas ao futebol, o time que carrega em si o nome da cidade construiria sua hegemonia.

Dos gols de Patusca às arquibancadas da praça de esportes na então nascente "Villa Belmiro". Os caminhos da cidade, do capital, do trabalho e da bola entrecruzam-se, evidenciando as contradições da Santos do início do século.

\subsection{Os tentáculos do grande capital e o mundo do trabalho: da luta ao lúdico}

Grande parte da história da moderna cidade de Santos está relacionada ao preponderante papel exercido no seu espaço urbano por duas grandes empresas: a Companhia Docas de Santos, presente desde fins do século XIX , e a Companhia Construtora de Santos, fundada, como o Santos Futebol Clube, em abril de 1912.

As duas empresas tiveram intensa participação nas profundas transformações urbanas, econômicas e sociais ocorridas em Santos no período, alterando de forma marcante tanto a paisagem urbana como as relações sociais vinculadas ao mundo do trabalho - o cada vez mais popular e disseminado futebol incluso. 
Comecemos pela mais jovem das duas empresas: a Companhia Construtora de Santos, fundada por Roberto Simonsen. Simonsen freqüentou a Escola Politécnica na cidade de São Paulo, onde se tornou engenheiro em 1909. Pouco tempo depois, trabalhou como diretor geral e como engenheiro chefe da Comissão de Melhoramentos de Santos. Após deixar a administração municipal santista, funda, em 1912, como principal acionista e diretorsuperintendente, a Companhia Construtora de Santos. A trajetória familiar e profissional de Simonsen não pode ser desprezada na análise da empresa que se formava. Roberto era neto de Ignácio Wallace da Gama Cochrane, engenheiro fiscal da construção da ferrovia SantosJundiaí e fundador da Companhia de Melhoramentos de Santos, mais tarde adquirida pela The City of Santos Improvements Company, empresa por sua vez responsável pela exploração de serviços públicos como abastecimento de água, iluminação e transportes.

As relações entre Roberto Simonsen e a administração pública local não se esgotavam no fato do mesmo ter sido funcionário da Prefeitura nos anos anteriores à fundação da empresa. Coraly Gará Caetano (1994, p. 29) afirma que:

\footnotetext{
"observando os estatutos da Cia. Construtora de Santos, é possível verificar que a criação desta empresa contou com o apoio e favores dos poderes públicos. Segundo a Lei Orgânica dos Municípios, lei 1.038, foi concedida a primazia por cinqüenta anos para esta empresa dirigir as obras públicas, com a isenção de impostos industriais, prediais e profissionais. Não sendo preciso, ainda, a abertura de concorrência pública. Estes privilégios permitiram inferir que, neste caso, o poder público colaborou diretamente na implantação da grande indústria na cidade e, em especial, para o crescimento da empresa de Simonsen."
}

O "apoio" citado no texto encontra ressonância na íntima relação existente entre Simonsen e o então prefeito, Belmiro Ribeiro de Moraes e Silva. Belmiro, prefeito municipal entre 1910 e 1914 e novamente entre 1917 e 1920, era um dos acionistas da recém-criada Companhia Construtora de Santos. A proximidade permaneceria nos anos vindouros. A Companhia Construtora de Santos, agora atuando sob a denominação de uma de suas subsidiárias, a Companhia Santista de Habitações Econômicas, seria responsável pela construção do bairro que eternizaria o seu nome, a Vila Belmiro, e pelo estádio - como veremos em detalhes mais adiante - do Santos Futebol Clube que, embora leve o nome de Urbano Caldeira, é mundialmente famoso pela denominação de seu bairro de origem. 
A empresa de Simonsen, beneficiando-se das íntimas relações com o poder público, crescia e expandia suas funções rapidamente. Já em 1913, a Companhia dispunha de 70 engenheiros e 18 mil empregados (SILVA e GITAHY, 1996, p. 95). Com uma estrutura desse porte, a empresa passou a atuar em áreas bastante diversas no setor de construção: obras diretamente relacionadas à urbanização, como arruamento, calçamento e abastecimento de água; edificação de prédios públicos, residências populares, armazéns, teatros, bancos, igrejas e praças esportivas. Em menos de três anos de existência, a empresa explorava pedreiras onde eram preparadas diversas peças de cantaria utilizadas nos serviços urbanos - de calçamento, por exemplo - da cidade (SILVA, 2003, p. 66).

A proximidade da empresa com o poder público local incidiria também sobre os projetos de habitação popular. Desde fins do século XIX, trabalhadores amontoavam-se nas chamadas "casas de cômodos", os populares cortiços. Mesmo após as campanhas de saneamento, os cortiços não tardariam a proliferar novamente. Característicos da região central da cidade e habitada sobretudo por trabalhadores de baixa renda, essa modalidade de moradia seria alvo de intensa política de intervenção. Seguindo uma lógica sanitarista que buscava regular as condições de habitação na cidade e expandir as possibilidades de investimento das grandes empresas capitalistas - como a empresa de Simonsen - organizadas para a construção de moradias populares, a prefeitura atacava as habitações coletivas através da política do "bota-abaixo".

A perspectiva do "embelezamento", tão característica das reformas urbanas da época, vinha acompanhada de uma política de extermínio dos cortiços e outras construções populares que fugissem aos padrões tidos como aceitáveis. A população desalojada acabava sendo atirada à rua, e as prometidas vilas e habitações operárias não chegaram a ser construídas nem pelo governo do Estado, nem pela municipalidade ou pelas empresas de capital privado como a empresa de Simonsen. Arranjando-se como podiam, os "desalojados" foram progressivamente empurrados para os morros e bairros menos valorizados, ficando segregados na moderna cidade que se formava.

Entretanto, apesar de gozar de situação favorável mesmo em conjuntura de crise econômica, a empresa não deixou de enfrentar, desde a sua fundação, a classe trabalhadora local. A posição destacada da empresa no setor e a rápida ampliação de suas atividades na cidade encontravam no organizado movimento operário da construção civil o seu contraponto. $\mathrm{O}$ até então consolidado controle do mercado de trabalho pelos trabalhadores qualificados, os "artistas" da construção civil, encontrou na Companhia de Simonsen um adversário capaz de redefinir os termos do confronto capital/trabalho. Exemplo disso é a inflexibilidade da 
empresa diante da greve dos canteiros de 1913. Vitoriosa em todas as pedreiras de Santos, a greve foi duramente reprimida pelas forças policiais nas regiões sob controle da Companhia Construtora de Santos, provocando a prisão de 75 trabalhadores e o estabelecimento de estado de sítio na cidade (SILVA, 2003). Sobre esse contexto, Silva e Gitahy (1996, p. 119) afirmam:

\footnotetext{
"A força do movimento operário dos trabalhadores da construção civil durante a belle époque residia no controle do mercado de trabalho pelas suas organizações. Para trabalhar, os "artistas" atestavam a sua condição de membros da Federação Operária Local de Santos que, desde 1912, reunia todos os sindicatos operários da cidade. Foi esta legitimidade, crucial nos momentos de greve, que os grandes construtores buscaram destruir na conjuntura da Primeira Guerra Mundial. Observava-se no setor, até então, uma união dos trabalhadores, concretizada pela existência da closed shop e, por outro lado, uma nítida divisão no interior do campo patronal. Os grandes construtores, via de regra, mostravam-se mais inflexíveis às reivindicações de seus empregados e, durante as greves, utilizavam os recursos do lock-out, das demissões e da repressão policial. Os pequenos mestres de obras, por sua vez, revelavam-se mais sensíveis aos acordos com os trabalhadores. Foi essa situação que Roberto Simonsen encontrou no momento da criação da Companhia Construtora de Santos, procurando revertê-la."
}

Em meados de 1916, os trabalhadores da construção civil de Santos voltam a se organizar e reativam o Sindicato de Pedreiros, Carpinteiros, Pintores e Serventes e a Federação Operária Local de Santos. Como resposta e por iniciativa de Simonsen, o setor patronal funda o Centro de Construtores e Industriais de Santos. Entre as medidas idealizadas por Simonsen através do Centro estavam a criação de um cadastro obrigatório para trabalhadores locais e a criação de uma Câmara de Trabalho, proposta supostamente conciliatória que buscava intermediar as relações entre capital e trabalho, esvaziando a influência dos sindicatos e organizações de classe. Em ambas as iniciativas, apesar de fracassadas, "caberia aos empresários a tutela de todas as esferas do mundo do trabalho" (SILVA e GITAHY, 1996, p. 120)

As estratégias do patronato, tendo no setor de construção a proeminência de Roberto Simonsen e de sua companhia, não se esgotariam nas propostas citadas, tampouco nas 
relações estabelecidas com a então Prefeitura Municipal. O auxílio de membros do poder público não se resumiria na participação acionária de Belmiro Ribeiro na empresa. O então Delegado Regional de Polícia em Santos, Bias Bueno, era advogado e conselheiro da empresa, "cabendo-lhe a função de manter a ordem e proteger a propriedade, além de controlar a seleção dos trabalhadores e arbitrar nos processos de demissão" (CAETANO, 1994, p. 31). A existência de uma mesma pessoa atuando como funcionário da empresa e como responsável pelas forças policiais naturalmente facilitava a perseguição a operários considerados "indesejados". Curiosamente, uma das justificativas para a criação do Centro de Construtores e Industriais de Santos foi a suposta violência contra a propriedade dos grevistas da construção civil (SILVA, 2003, p. 72).

Apesar da estratégia de repressão policial conjugada a posições pretensamente conciliatórias, as greves não cessariam. Em 1917, por exemplo, os trabalhadores da construção civil paralisariam suas atividades com adesão de ferroviários, canteiros, trabalhadores do Saneamento, carroceiros e ensacadores de café (idem, p. 84). O Centro, capitaneado por Simonsen, denunciava a "intransigência" dos grevistas ao mesmo tempo em que reforçava a proposta de criação da Câmara de Trabalho, medida de negação da idéia de representação pelo sindicato embora apresentada como veículo de diálogo entre patrões e trabalhadores.

As malogradas iniciativas de Simonsen no campo conciliatório não escondem o fato de que as greves de 1916 e 1917 foram, para os trabalhadores, pouco efetivas. Entretanto, durante as ondas grevistas de 1919 e 1920, os trabalhadores ligados ao setor da construção civil teriam, novamente, papel de destaque.

A greve dos canteiros, categoria profissional que, como veremos, teria destaque na proliferação do futebol santista, desencadeada em dezembro de 1920, foi amplamente vitoriosa, sendo responsável pela retomada dos níveis salariais anteriores a 1913 (GITAHY, 1992, p. 95).

Se os trabalhadores da construção civil e os trabalhadores portuários eram as duas categorias consideradas mais organizadas e combativas da cidade de Santos, a Companhia Construtora de Santos e Companhia Docas de Santos foram, durante as décadas mais intensas de transformação do espaço urbano santista, os representantes do grande capital privado.

A Companhia Docas, com apoio do governo federal - importante lembrar que a empresa criada por Guinle e Gafreé tinha sua sede na cidade do Rio de Janeiro - logo monopolizaria todas as operações de carga e descarga realizadas em terra no porto de Santos. Depois da greve pela jornada de oito horas, em 1908, apenas os estivadores - que operavam no interior dos navios - não foram totalmente absorvidos pela Companhia Docas na região do 
cais (SILVA e GITAHY, 2012, p. 24). Embora o contrato firmado em 1888 com o governo imperial não especificasse o monopólio, a empresa foi, paulatinamente, controlando o processo de trabalho, mantendo, inclusive, um corpo permanente e bastante numeroso de trabalhadores, como motorneiros, maquinistas, foguistas, marinheiros, carpinteiros, pedreiros, serventes, vigias e zeladores (SILVA, 2003, p. 175).

Foi no porto que, até meados dos anos 1910, as greves tiveram maior visibilidade e impacto. Em uma economia voltada primordialmente para a exportação de café, os transportes tornavam-se definitivamente um setor estratégico.

Em Santos, a iniciativa privada foi inequivocamente amparada pela proteção estatal. Assim como no caso de Simonsen e sua Companhia e a Prefeitura Municipal, a proximidade da Docas com o governo federal trouxe à empresa diversos benefícios. A Companhia rapidamente expandiria seus tentáculos para outras atividades, como produção de energia elétrica, armazenagem e exploração de pedreiras, gozando de isenções fiscais e vantagens na desapropriação de terrenos, apesar das pressões das administrações municipais santistas no sentido contrário (Idem, p. 176)

A enorme sombra exercida pela Companhia Docas e que se manifestava regularmente no padrão inflexível da empresa no trato das paralisações de seus trabalhadores, no entanto, encontrava limites na própria natureza do trabalho portuário. A cultura de trabalho e as redes de sociabilidade extrapolavam o universo meramente laboral. Sobre essa questão, é importante ressaltar que:

\footnotetext{
"a vastidão do porto e certo anonimato nele existente implicavam familiaridade e formação de redes informais, de cujos vínculos podiam depender a sobrevivência dos trabalhadores e o aprendizado de formas secretas de resistência. As relações sociais também preexistiam àquelas estabelecidas no trabalho. Laços pessoais e familiares eram acionados desde o momento da contratação da força de trabalho, criando múltiplas lealdades e tradições de trabalho transmitidas de geração em geração, de modo que muitas famílias foram socializadas no porto, criando verdadeiras linhagens de militância e experiência sindical. Em suma, esses fatores de solidariedade criavam terreno propício à ação coletiva, no âmbito estritamente laboral ou fora dele." (SILVA e GITAHY, 2012, p. 25)
}

O senso de pertencimento associado a experiências comuns foram constituindo, entre os trabalhadores da cidade, uma forte cultura associativa. $\mathrm{O}$ trabalho ocasional estreitava a 
proximidade entre moradia e fontes de emprego, fazendo com que os trabalhadores do porto fossem muitas vezes vizinhos e habitassem nas localidades contíguas ao cais, como os bairros do Macuco, Vila Mathias, Paquetá e a região central da cidade. Para além dos sindicatos e organizações operárias, diversas associações mutualistas, aproximadamente quarenta em Santos entre 1891 e 1920 (LUCA, 1990, p. 20), sociedades beneficentes, jornais e, enfim, clubes e times de futebol, foram se formando.

\subsection{A classe trabalhadora entra em campo}

Para a análise específica desse aspecto utilizaremos como pano de fundo a reflexão de Milton Santos (1980), que, ao examinar as cidades sob á ótica do desenvolvimento desigual, procurou perceber como há grande autonomia das classes populares no sentido de empreender a conquista do espaço territorial e fazer dele seu lugar de uso - seja para moradia, lazer, etc. -, mesmo em sociedades fortemente excludentes, como a cidade de Santos no período analisado. As questões que se colocam, a partir das premissas anunciadas nos capítulos anteriores e diante dos indicadores inicialmente considerados são: como explicar que, apesar dos sinais eloqüentes de progresso, a cidade mal disfarçava o seu outro lado, o seu avesso, consubstanciado em paradoxos? Como se deu, em uma sociedade segregada socialmente e em espaço relativamente curto de tempo, a apropriação da inicialmente elitizada prática do futebol pela classe trabalhadora e extratos mais pobres da população local?

O fenômeno, contudo, não se restringiu ao espaço urbano santista. José Geraldo Vinci de Moraes, em estudo já citado, indica que:

"no desenrolar da década de 1910 iniciou-se um processo de completa inversão no futebol brasileiro. Deixando de ser apenas espectadora dos meetings e torcedora nas arquibancadas, a população mais pobre começou a fundar os seus próprios times. (...) Diante desse novo quadro, a ordem pública avaliava esse tipo de futebol como uma perturbação. Ele desarranjava o universo do lazer regrado (porque era informal), do trabalho (porque era, supostamente, praticado por desocupados) e da disciplina e da lei (porque os praticantes não seguiam integralmente as regras e os jogos, às vezes, descambavam para a violência). Gradativamente, o futebol foi deixando de ser o esporte de uma elite pretensamente moderna para ser visto como uma atividade marginal." (MORAES, 1994, p. 95) 
O futebol rapidamente ganhou novos adeptos, rompendo barreiras de classe e se espalhando pelos quatro cantos da cidade. O pequeno surto do início do século se tornaria epidemia efetivamente na década de 1910.

Apenas em 1913, quatro clubes dedicados ao futebol foram fundados na cidade: Clube Atlético Santista, Brasil Futebol Clube, América Football Club e Clube Atlético Edu Chaves. Eles se somariam ao recém fundado Santos Futebol Clube e ao Santos Athletic Club (Clube dos Ingleses), clube de criado em 1889 inicialmente para a prática de cricket e para atividades culturais da colônia britânica local. O ritmo seria mantido em 1914, com o surgimento da Associação Atlética Americana (fundada por iniciativa de Raymundo Marques após cisão entre fundadores e primeiros dirigentes do Santos F.C.), Associação Atlética Aliança, Chantecler (de São Vicente, município vizinho a Santos), São Paulo Railway, Atlas-Flamengo e Hespanha Football Club, hoje conhecido como Jabaquara Atlético Clube. A profusão de equipes permanece nos anos seguintes: Vera Cruz Futebol Clube (1915), Síria Futebol Clube (1915), Clube Atlético Luzitano (1915), Libertário Futebol Clube (1916), São Bento Futebol Clube (1916), XV de Novembro Futebol Clube (1916), Associação Atlética Internacional (1917), Associação Atlética Portuguesa (1917), União Fluminense (1918), Tecelagem Futebol Clube (1918) e Palestra Itália (1919) formariam amplo espectro de quadros futebolísticos na cidade durante a década de 1910.

Cumpre aqui salientar, para além do aspecto quantitativo, o que nos interessa efetivamente ao analisar a difusão e popularização do futebol na cidade de Santos: de que forma a disseminação de sua prática, especialmente entre elementos da classe trabalhadora, produziu novos lugares e novas formas de se relacionar com a cidade? De que forma a apropriação do antes elitizado esporte contribuiu para o surgimento de uma nova espacialidade e de novas formas de sociabilidade no espaço urbano?

Alguns estudos, como o de Fátima Antunes (1992), já se debruçaram sobre a inicial negação do futebol - prática considerada "imperialista" e responsável pela "alienação" do trabalhador - por anarquistas e comunistas e a sua progressiva aceitação e incorporação aos programas culturais associados à militância. Embora escassas, as referências encontradas na imprensa de origem operária, indicam essa tendência na cidade de Santos. Em breve nota publicada no dia 25 de junho de 1912, o jornal O Proletário, periódico ligado principalmente aos trabalhadores da construção civil anunciava que: 
“o perigo representado pela prática burguesa do futebol reside no roubo de suas forças, no deslocamento de suas energias para o confronto contra outros trabalhadores"

O "perigo" representado pelo futebol continuaria preocupando parte dos dirigentes sindicais nos anos seguintes. Em artigo sobre a Federação Operária Local de Santos publicado no jornal carioca $A$ Voz do Trabalhador em abril de 1914 por Serafim Soler, membro e dirigente da FOLS, a posição sobre o "esporte bretão" se confirma:

\footnotetext{
“embora seja inegável o interesse que o foot-ball possui entre os trabalhadores, não podemos deixar de considerar que o momento de perdas e dificuldades exige dedicação absoluta. As distrações e as rivalidades estimuladas entre trabalhadores devem ser evitadas".
}

A crítica não era incomum. Em passagem do jornal A Plebe do final dos anos 1910 citada por Maria Auxiliadora Decca (1987, p. 119), enfatizava-se que:

\footnotetext{
"atualmente, são três os meios infalíveis que os ricos exploradores das misérias e necessidades do povo empregam para tornar a classe operária uma massa bruta: o esporte, o padre e a política. Não existe nenhuma vila ou aglomerado de casas de operários que não tenha o campo de futebol, a igreja e os gorjetados incitadores políticos. Nos campos de futebol, os operários de ambos os sexos tornam-se aficionados e torcedores e brutalizam-se a ponto de só viverem discutindo entre os seus companheiros os lances e proezas dos campeões"
}

A visão do futebol como ópio por parte de certos dirigentes operários contrastava com a ampla adesão de trabalhadores ao esporte. Embora visto de forma recorrente como meio de submissão da classe operária aos interesses do patronato e como veículo de conformação dos trabalhadores à lógica industrial - no sentido de imbuir o trabalhador de senso de coletividade, de disciplina, de hierarquia, de competitividade e de valorização do tempo - é importante enfatizar que, a despeito de eventuais interesses empresariais, o futebol representava parte fundamental das experiências de sujeitos envolvidos em complexa teia de relações de poder. A difusão do futebol como prática popular se insere de forma indissociável na própria formação da classe trabalhadora santista. 
No tocante as primeiras equipes de futebol da cidade de Santos fundadas em meados dos anos 1910, dois aspectos precisam ser ressaltados: a origem popular de alguns desses clubes e o profundo recorte de nacionalidade existente entre eles.

O surgimento dos dois mais importantes "times de colônia" da cidade oferece privilegiada oportunidade de se discutir ambos.

\subsection{Hespanha e Portuguesa: canteiros, jornaleros e os "times de colônia"}

O grande número de imigrantes e de estrangeiros residentes em Santos contribuiria decisivamente para a rápida popularização do futebol local. Todas as nacionalidades de maior representação na cidade possuíram o seu correspondente clube de futebol - em alguns casos, mais de um. Alguns clubes, como o Hespanha Football-Club e a Associação Atlética Portuguesa deixavam claro, já em suas atas de fundação, o objetivo de criar times de futebol que representassem, respectivamente, a colônia espanhola e a colônia portuguesa. As fundações de Luzitano, Síria e Palestra Itália, embora de análise limitada pela quase absoluta escassez documental, parecem caminhar na mesma direção.

Assim como as anteriormente citadas associações de classe e de auxílio mútuo, os clubes de futebol vão, progressivamente, fortalecendo laços de solidariedade social caracterizados pelo reforço da idéia de pertencimento a uma origem comum, no caso representado pela concepção de nacionalidade. Richard Giulianotti (2010), ao discutir o significado do jogo de futebol a partir da concepção de solidariedade social, aponta que a vida moderna tende a quebrar a idéia de comunidade. A industrialização, a urbanização, a mobilidade social e geográfica e as divisões mais complexas de trabalho desintegram a vida comunitária e as identidades sociais estabelecidas. Todavia, o esporte pode "restaurar muito esse dano social, intensificando os vínculos culturais e a integração social de diferentes indivíduos dentro das sociedades modernas" (GIULIANOTTI, 2010, p. 31).

A formação de clubes de futebol - notadamente caracterizada por recortes de classe, ou de nacionalidade (de ambos, em alguns casos) - e a associação crescente e voluntária de torcedores ajudavam a equilibrar sentimentos de atomização em uma cidade em acelerado crescimento e intenso processo de segregação espacial a partir de um determinado modelo de urbanização.

O primeiro aspecto analisado, a origem popular de alguns clubes, é menos óbvio e requer cuidadosa observação de informações quase sempre fragmentadas. Se por um lado, agremiações como Santos Futebol Clube, Associação Atlética Americana, Clube Atlético 
Santista e Brasil Futebol Clube apresentavam entre seus fundadores representantes do grande comércio local, funcionários graduados de grandes empresas como a Companhia Docas e membros da elite política local, algumas outras equipes dedicadas ao futebol surgiram de setores médios e mais modestos da população santista.

A edição comemorativa, publicada em janeiro de 1939, do jornal $A$ Tribuna em virtude do centenário da elevação de Santos à categoria de município nos traz alguns dados importantes. Em reportagem sobre as primeiras décadas do futebol em Santos, o periódico cita a fundação do Hespanha Football-Club como "obra de abnegados jornaleros de origem espanhola". Uma pequena nota no periódico O Diário de Santos, por conta do título obtido pelo Hespanha no campeonato santista da segunda divisão de 1919, reforça essa perspectiva ao afirmar que o "clube fundado por jornaleros espanhóis há apenas cinco anos vem conseguindo destaque cada vez maior". Em estudo recente sobre imigração européia na Santos da Belle Époque, Marília Canóvas (2017) nos oferece importante contribuição sobre uso do termo. Segundo ela:

\footnotetext{
"O sentido semântico que os censos atribuem ao termo "jornalero" não se refere unicamente às formas de percepção do salário, refletindo, por outro lado, a questão da instabilidade do emprego. Daí, os censos incluírem na categoria de jornaleiros nas cidades a todos os trabalhadores sem um ofício preciso, cujos afazeres cotidianos se movam, no decorrer do ano, em âmbitos muito distintos: servente de pedreiro, biscateiro, estivador, mensageiro, pedinte. A categoria "jornalero" passou a acomodar a complexa realidade de populações que por vezes tangenciavam a miséria absoluta"
} (CÁNOVAS, 2017, p. 156).

O termo "jornaleiro" aparece com bastante freqüência na obra clássica - e citada anteriormente - de Guilherme Álvaro sobre as epidemias e as campanhas de saneamento em Santos. Nessa obra, a categoria aparece geralmente em referência àqueles que "trabalhavam no cais e na construção" (ÁLVARO, 1919, p. 156) e a trabalhadores majoritariamente espanhóis e portugueses. $O$ autor refere-se aos jornaleiros como "trabalhadores braçais".

A rubrica auto-atribuída de "jornalero", segundo a análise feita por Cánovas (2017) a partir de registros consulares de imigrantes espanhóis, indica que:

"seu uso por parte do imigrante implicou evocar uma sensação de experiência já vivenciada de instabilidade e desajuste, traduzindo-se, no 
concorrido mercado de trabalho da cidade, na aceitação de qualquer trabalho, tarefa ou incumbência esporádica e/ou temporária, ou do subemprego, sem garantias e de baixa remuneração. Em outros termos, essa condição auto-atribuída e declarada se caracterizava, na luta cotidiana, pela aceitação de qualquer oferta de trabalho eventual ou pela busca de soluções improvisadas e arranjos provisórios que lhes garantissem ao menos a sobrevivência, mas também designava a consciência de sua condição." (CÁNOVAS, 2017, p. 156/157)

Importante destacar outro aspecto apontado pela autora. Se na primeira década do século XX predominava entre os imigrantes espanhóis a rubrica auto-declarada de "operário" denominação geralmente relacionada a trabalhadores formais de empresas como Docas, City, São Paulo Railway, Moinho Paulista, Moinho Santista ou no setor público para a Comissão de Saneamento -, nos anos 1910, período de fundação do Hespanha, a categoria "jornalero" adquire proeminência junto aos trabalhadores de origem espanhola radicados em Santos. Esse aspecto pode estar relacionado às sucessivas crises econômicas do período e à conseqüente precarização do trabalho na cidade.

O clube foi fundado em novembro de 1914 no bairro conhecido como Jabaquara (ver imagem 18, p. 142). Caracterizado pelo pequeno comércio e pela presença expressiva de trabalhadores a serviço da Companhia Docas e da Companhia Construtora, o bairro tinha na exploração da pedreira existente nos arredores da Santa Casa de Santos a sua atividade econômica fundamental (ver imagem 17, p. 142). Na pedreira do Jabaquara, de onde eram extraídas as pedras para a construção do porto, de obras de saneamento e melhoramentos urbanos, concentrou-se grande contingente de trabalhadores, em geral empobrecidos. Nessa época, o serviço de exploração das pedreiras na região estava sendo disputada judicialmente pelas duas grandes empresas em questão (HONORATO, 1996, p. 82). Poucos anos depois, em meados da década de 1920, o clube se transferiu para o bairro operário, notadamente portuário, do Macuco, próximo ao cais do porto, onde teria seu primeiro estádio, nomeado a partir do proprietário do terreno e simpatizante do clube, Almino Alonso.

Os registros oficiais do clube trazem interessantes informações sobre o caráter popular da nova agremiação que surgia. Segundo eles, a reunião que deu origem ao clube foi realizada na casa do zelador José Domingues, localizada na "escada de pedras no sopé do morro da pedreira do Jabaquara". Ainda segundo os registros, a sugestão inicial para o nome da agremiação foi Nova Cintra - referência ao morro da Nova Cintra, em Santos -, já que a 
"maioria dos fundadores lá residia". Como discutido em momentos anteriores, a ocupação dos morros pela classe trabalhadora no período foi um desdobramento do excludente processo de "modernização" vivenciado no espaço urbano santista no alvorecer no século XX. A denominação Hespanha carrega em si também bastante significado. A agremiação teria recebido esse nome por sugestão de um "antigo escravo do quilombo do Jabaquara", por este considerar que o nome seria representativo da nacionalidade hegemônica entre os fundadores do clube.

A manutenção do clube, especialmente nos primeiros anos, refletia o contexto de sua criação. Os sócios não eram muitos e "as mensalidades eram de mil réis, correspondente a dez tostões, o que mal dava para que a agremiação conseguisse sobreviver" (SILVEIRA, 2002, p. 18). A solução encontrada foi a realização das chamadas "provas de honra", festivais esportivos que serviam como campanhas de arrecadação para que o clube permanecesse vivo. Em 1917, por exemplo, o então presidente Odillo Prieto Garcia promoveu um festival no campo da avenida Conselheiro Nébias, pertencente ao Brasil Futebol Clube, com esse objetivo. Além da vitória sobre o outrora poderoso time da São Paulo Railway por 2X1, o evento rendeu ao clube "a importância de 865 mil réis." (idem, p. 20) O clube ganharia sobrevida, ao menos temporária, e se consolidaria, após a sua filiação à Associação Santista de Esportes Atléticos (ASEA), como parte integrante do amplo espectro futebolístico santista nos anos 1910.

Pouco depois da fundação do rubro-amarelo do bairro do Jabaquara, surge, em 1917, a Associação Atlética Portuguesa (ver imagem 19, p. 143). A já citada edição de $A$ Tribuna de janeiro de 1939 sobre os primeiros anos do futebol santista apresenta o surgimento do clube como fruto de iniciativa de "canteiros portugueses da região da pedreira do bairro do Jabaquara, desejosos em criar um clube de colônia como espanhóis, ingleses e sírios já haviam feito". Em publicações de origem operária como O Proletário e O Dois de Fevereiro, as referências aos "canteiros" dão conta de trabalhadores da construção civil com certo grau de especialização. Segundo Ana Lucia Duarte Lanna (1996, p. 56), "os trabalhadores das pedreiras, os canteiros, que abasteciam a Companhia Docas para as obras do porto, residiam majoritariamente em morros, principalmente o morro do São Bento no caso dos portugueses".

$\mathrm{Na}$ ata de fundação, realizada em barbearia do português Alexandre Coelho, constam os nomes de pequenos comerciantes, como donos de mercearias, e de quatro trabalhadores da Companhia Docas, possivelmente os canteiros citados na reportagem.

A fundação da Portuguesa, segundo registros do clube, é apresentada como fruto do contato de canteiros portugueses da pedreira do Jabaquara e trabalhadores espanhóis da mesma região vinculados ao Hespanha. A iniciativa para a criação do clube é explicada pela 
"necessidade de se formar uma agremiação representativa da colônia portuguesa da mesma forma que os espanhóis já o fizeram." (SILVEIRA e ROGÉRIO, 2017, p. 18)

A proximidade entre Hespanha e Portuguesa não era, entretanto, meramente geográfica. Alguns dos fundadores da agremiação lusitana - como Serafim de Almeida, José de Mello, Abel Rabelo, Manoel Tavares e Antônio de Almeida - foram, entre 1916 e 1917, sócios do clube espanhol do bairro do Jabaquara.

As semelhanças e aproximações não param por aí. As primeiras atas do clube após a sua fundação evidenciam a calamitosa situação financeira da agremiação. Em uma delas, consta a aprovação da compra de um livro para o tesoureiro do clube "quando for possível juntar recursos para tal." A realização de festivais esportivos e a organização de campanhas de arrecadação eram apresentadas nas reuniões como forma de "fechar as contas". Em uma reunião de outubro de 1918, o então presidente Lino do Carmo sugere que os jogadores deveriam pagar pelas suas próprias camisas, "uma vez que não há dinheiro em caixa."

O clube passaria a utilizar como campo de jogo terreno situado na confluência das avenidas Pinheiro Machado e Bernardino de Campos (confluência também dos canais 1 e 2), em frente ao Morro do Lima, próximo da região da pedreira do Jabaquara. Localizado junto à linha férrea da Companhia Docas, o terreno não parecia empolgar sequer os diretores do clube. Em ata de janeiro de 1918, um deles afirma que o terreno resume-se a "um matagal com pedras". Pouco menos de três anos depois, em dezembro de 1920, a Associação Atlética Portuguesa inauguraria nesse mesmo local a sua praça de esportes (ver imagem 31, p. 149). 0 local receberia o nome de Ulrico Mursa, em homenagem ao português que seria figura central na construção de uma nova espacialidade urbana associada ao futebol. Discutiremos essa questão mais adiante.

Embora os denominados "times de colônia" tenham sido representativos do processo de popularização do futebol na cidade de Santos na década de 1910, eles não foram os únicos a demonstrar a penetração do esporte bretão junto à classe trabalhadora e à população mais empobrecida da cidade.

As referências a outros clubes do período são bastante restritas e o caráter efêmero de tais agremiações dificulta o acesso a acervos documentais. No entanto, as esparsas citações nos dão indicações interessantes. O jornal O Diário de Santos, em edição de outubro de 1917, faz referência ao Atlas-Flamengo como agremiação criada por "trabalhadores da construção". Anos depois, no início da década de 1940, o jornalista Perilo Prado, em retrospectiva sobre o futebol santista publicada pelo jornal A Tribuna, afirmava que os fundadores do AtlasFlamengo eram trabalhadores que "davam duro nos canteiros de obra". Na ata de fundação do 
clube, único documento oficial encontrado até o momento - disponível no Arquivo Permanente da Fundação Arquivo e Memória de Santos -, foi possível identificar os nomes de Manoel Fernandes Scala e Luis Scala, ambos presentes em listas de filiação da Federação Operária Local de Santos (SILVA, 2003, p. 158). O clube, sediado no bairro do Macuco, ocupado predominantemente por trabalhadores do cais e da construção civil, ficou em atividade até fins da década de 1920. Outro exemplo de clube localizado no bairro portuário do Macuco foi o América Futebol Clube. Fundado em 1913, o América surgiu por iniciativa de trabalhadores do setor de transportes ligados ao porto, muitos deles empregados da Companhia Docas. As listas de filiação ao clube indicavam ainda quantidade expressiva de trabalhadores caracterizados como "operários" da Companhia Docas. Segundo registros da empresa, as seguintes ocupações/profissões designavam os "operários" contratados pela empresa: ferreiros, serralheiros, maquinistas, foguistas, carpinteiros, britadores, pedreiros e caldeireiros. O clube daria origem, na segunda metade da década de 1920, à Associação dos Portuários de Santos, agremiação ainda em atividade.

Embora escassas, as fontes indicam a difusão e penetração do futebol por todos os poros da sociedade santista. Uma febre a invadir ruas, terrenos baldios, pequenos campinhos e os primeiros estádios.

$\mathrm{Na}$ cidade que se formava, bairro a bairro, a expansão do futebol exigia novos espaços e edificações que comportassem o seu crescimento. O surgimento e conseqüente expansão dos estádios, elemento fundamental da conversão do futebol em espetáculo esportivo, reflete a ação combinada de empresários e do poder público. O brilho do campo de jogo ofuscava as nebulosas relações entre setor público e setor privado na reorganização espacial da cidade.

\subsection{A bola rola nos caminhos da cidade: capital, trabalho e futebol na Santos dos anos $\mathbf{1 9 1 0}$}

A expansão portuária, as intervenções urbanas de caráter sanitarista e a instauração de uma rede de serviços públicos se constituíram em elementos fundamentais nas modificações do espaço urbano santista e da sociabilidade urbana no último quarto do século XIX e primeiras décadas do século XX. O conjunto de obras e melhorias urbanas implantadas nesse período significou a integração da cidade portuária às transformações que estavam ocorrendo em âmbito nacional no final do século XIX - e que incluíam uma política de desobstrução, reorganização e reordenação dos espaços urbanos. A remodelação urbana era parte essencial nessa tarefa e modernizar o porto e as ruas para permitir livre acesso das 
mercadorias era problema fundamental que o desenvolvimento do novo capital privado requeria.

Pensando a cidade como expressão dos padrões de uma classe que se projetam em seus espaços físicos (SCHORSKE, 1988), essas transformações criaram novas formas desejáveis de viver na cidade; na casa ou na rua, esse foi um momento de inserção e de consolidação de novos valores. Por outro lado, as oportunidades de emprego produzidas pelo crescimento do porto, e como desdobramento, da cidade de Santos no final do século XIX atraíram um grande número de trabalhadores, em geral bastante empobrecidos. As formas de compreender e lidar com essa "nova ordem social" caracterizada tanto pelo crescimento demográfico quanto pelo aparecimento e disseminação dos cortiços se traduziram em intervenções urbanas que acabariam por definir as cidades como espaços que dividiriam as funções de moradia, de trabalho e de lazer:

\footnotetext{
"Se a expansão da cidade e a concentração de trabalhadores ocasionaram inúmeros problemas, a segregação social impedia que os diferentes estratos sociais sofressem da mesma maneira os efeitos da crise urbana, garantindo às elites áreas de uso exclusivo, livres da deterioração, além de uma apropriação diferenciada dos investimentos públicos." (BONDUKI, 1998, p.20)
}

A expansão urbana delineava novos espaços e usos da cidade. O acesso a serviços públicos e os benefícios da modernidade que se pretendia instaurar não eram para todos:

\begin{abstract}
“O delineamento classista dos bairros era claro já no início do século [XX], talvez até mais evidente do que em nossos dias, quando tais limites muitas vezes parecem borrados. Distinção geográfica que não transparecia somente nas fachadas das casas. Era igualmente denunciada pela diferente topografia e saneamento do solo, pela distribuição desigual dos serviços urbanos (iluminação, calçamento, água, esgoto, gás, coleta de lixo, bonde, telefone, ajardinamento e correios) e pelas distâncias guardadas em relação a indústrias e ferrovias. [...] O mesmo processo que introduzia melhoramentos públicos, elegia os excluídos desses benefícios." (GAMBETA, 1991, p.25)
\end{abstract}

Desde o início do novo século se acentuou, em decorrência das reformas, o incessante deslocamento involuntário da população nas áreas urbanas santistas. Consolidavam-se os 
traços originais da futura constituição da cidade, com a formação de distintas redes sociais de apropriação do espaço, com repercussões na fragmentação e na setorização de Santos.

Santos expandiu-se, primordialmente, para leste na direção do Atlântico, graças às linhas de bondes, à abertura de novas avenidas e à construção da rede de canais. As antigas chácaras ali existentes foram loteadas e considerável parte dos moradores das regiões centrais, em virtude de processo sanitarista já mencionado, foi deslocado para a região dos morros ou para novos bairros que estavam sendo formados, como o Macuco, a Vila Mathias, o Gonzaga e a Vila Belmiro. Segundo Maria Carolina Mazeviero, o crescimento urbano da cidade pode ser explicado através de dois vetores distintos:

\footnotetext{
"de um lado, o vetor da exclusão ao qual pertenciam os trabalhadores, os imigrantes e os ex-escravos que passaram a ocupar a região central da cidade, as encostas dos morros e os chamados arrabaldes mais próximos ao perímetro urbano. (...) De outro lado, o vetor da valorização fundiária seguia os investimentos imobiliários ao longo das avenidas Conselheiro Nébias e Ana Costa seguindo em direção à praia da Barra, onde surgiam os primeiros casarões e palacetes da elite, além de hotéis e clubes de luxo que transformavam a orla em núcleo de lazer da nova e moderna cidade. Portanto, a expansão urbana de Santos foi marcada pela cisão da cidade em dois núcleos sociais pelas reformas urbanas, pois, na medida em que estas empurravam a população pobre para a periferia também criavam condições de ocupação e valorização da orla. Estas transformações que ocorreram na cidade foram conduzidas por agentes estatais e patrocinadas pelo capital privado." (MAZEVIERO, 2008, p. 47)
}

O capital privado não apenas patrocinava, mas pavimentava os caminhos da cidade "moderna" que surgia.

A área à beira-mar passou a ser ocupada pelas famílias de posses da região, onde moravam ou passavam temporadas de veraneio em chácaras e onde foram sendo construídos hotéis e espaços destinados ao lazer. Essa área contrastava com a zona central, onde se concentrava a área comercial, de funcionamento do porto, de habitação de trabalhadores ligados ao porto, à ferrovia, aos diversos armazéns e depósitos ali instalados e também onde havia o maior número de cortiços devido ao grande número de trabalhadores que vieram para Santos. As praias para o lazer, o Centro para o comércio, o estuário para o embarque do café e as áreas próximas a serra para as indústrias. A reordenação dos espaços na cidade de Santos 
do início do século XX promoveu intenso processo de segregação sócio-espacial (LANNA, 1996, p. 102). Se, como demonstra Matos (2005), as condições habitacionais da população pobre santista eram caracterizadas pelo predomínio de cortiços erguidos em pátios e quintais - sem acesso a água, esgoto ou iluminação - localizados em becos e vielas das regiões centrais da cidade, a ocupação da região das praias pelas elites locais, seguindo uma lógica de evolução urbana caracterizada por grandes vias, linhas de bonde e ampliação dos serviços urbanos, ditava os rumos do desenvolvimento citadino.

O deslocamento das elites do centro de Santos em direção às praias reorientou o sentido de expansão da cidade. A construção, ainda no final do século XIX, de grandes hotéis na via costeira e de inúmeros estabelecimentos voltados ao lazer para aqueles que o podiam consumir, acabou por romper com a antiga lógica de centralidade da cidade.

A expansão da cidade rumo à orla trouxe consigo o surgimento de uma variedade de atividades de lazer - como cinemas, cassinos, rinques de patinação, salas de jogos e danças e a descoberta do footing à beira-mar. A construção desses inúmeros empreendimentos modificou significativamente os usos da cidade. O predomínio da esfera privada avançava à medida que diversos estabelecimentos comerciais das mais variadas ordens eram inaugurados, alterando os padrões do consumo de parte da população e introduzindo novos costumes e hábitos. Esse processo, que parecia ser para todos, já indicava as distinções sociais que recortavam a sociedade santista. Indicando as mudanças de Santos na época, diversos memorialistas destacaram o surgimento de uma vida urbana movimentada, de teatros, cassinos, lojas com vitrines que exibiam uma diversidade de produtos, bares, restaurantes, clubes e hotéis. As ruas, agora com calçadas, permitiam à população passear e tomar contato com as novidades do comércio sofisticado que surgia para atender às suas novas demandas. 0 espaço da rua e das praças tornou-se mais agitado, com maior trânsito de pessoas, veículos e lojas, mas era cada vez menos "na" rua que estava a vida da cidade. O divertimento cada vez mais veio a se associar ao recebimento de uma renda ou do salário, principalmente a partir da última década do século XIX. As festas e espetáculos - de futebol, inclusive - aconteciam cada vez menos nas ruas e cada vez mais em clubes, onde se pressupunha a condição de sócio ou de convidado para participar, o que implicava uma seleção da convivência. A própria ocupação dos espaços nos espetáculos - como veremos mais adiante - era mediada pela possibilidade de se pagar por ela.

As festividades já não mais se passavam nas ruas, e quando ainda aconteciam era sob uma nova forma, caracterizada por certa concepção de anonimato. Essas mudanças transformaram o espaço da rua em local de espetáculo, de fruição pelo olhar, de local de 
trânsito disciplinado de mercadorias e pessoas, afirmando a concepção burguesa do viver em cidades. Com suas antigas funções esvaziadas, ao passo que outras surgiam, a rua, segundo Lanna (1996, p.106):

\footnotetext{
“deverá guardar no seu contorno os elementos desta nova sociedade. Simbolizar enquanto linearidade vista como vitória da racionalidade. E ao seu redor vão aparecendo os elementos indicativos da nova rua formando a nova cidade: a calçada que separa o trânsito dos pedestres e dos veículos; as lojas com vitrines simbolizando o mundo fascinante e fetichizado da mercadoria e do anonimato; os espaços semi-públicos ou essencialmente privados de lazer como consumo do tempo livre."
}

Entre os espaços de consumo do tempo livre, os dedicados exclusivamente aos espetáculos de futebol. Se a expansão da cidade era tratada pelo grande capital privado como oportunidade de negócios, o cada vez mais popular futebol seria parte constituinte desse processo de transformação.

Em uma cidade em formação e transformação, marcada pelos intensos conflitos entre capital e trabalho e por acentuado processo de segregação sócio-espacial, o futebol se traduzia em experiência cultural compartilhada, complexa, contraditória como o espaço urbano que o abrigava.

O ano de 1912 é, como vimos anteriormente, fundamental para a análise das transformações ocorridas em Santos nos anos e décadas subseqüentes. A tênue linha divisória entre público e privado encontraria no futebol em expansão um de seus elementos constitutivos.

No campo esportivo, a fundação do Santos Futebol Clube, em meados de abril. No campo empresarial, curiosamente no mesmo mês de abril, a fundação da Companhia Construtora de Santos por Roberto Simonsen.

De um lado, o surgimento do clube que representaria o ponto de inflexão do processo de popularização do futebol na cidade. De outro, o surgimento da empresa que seria responsável por profundas mudanças no espaço urbano santista, reorganizando a paisagem, criando novos bairros e, conseqüentemente, alterando padrões de sociabilidade e modos de viver.

A atuação da empresa de Simonsen, como visto no decorrer desse capítulo, era bastante diversificada e se espraiava por quase todos os segmentos do setor de construção: 
obras diretamente relacionadas à urbanização, como arruamento, calçamento e abastecimento de água; edificação de prédios públicos, residências populares, armazéns, teatros, bancos, igrejas, etc.

A inserção efetiva de Simonsen e de sua Companhia no campo de jogo não tardaria a acontecer. Novamente, as trajetórias da Companhia Construtora de Santos e do Santos Futebol Clube se cruzariam.

Em abril de 1915, três anos após a sua fundação, o então presidente do Santos Futebol Clube, Agnello Cícero de Oliveira, solicitou a formação de uma comissão de sócios do clube tendo em vista a "necessidade urgente da construção de um campo de football com todas as acomodações e instalações que se fazem precisar aos nossos jogadores e aos nossos apreciadores."

O primeiro terreno analisado pela comissão era de propriedade de Oswaldo Sampaio, negociante do ramo de café. Localizado na região conhecida na época como Campo Grande, o espaço encontrava-se, nas palavras dos sócios e membros da comissão Luiz Suplicy e Sebastião Arantes, "edificada com pequenas casas de madeira", o que poderia trazer ao clube, caso o negócio fosse concretizado, "grande prejuízo além do custo para desalojar os indivíduos do terreno". Apesar das pendências referentes ao espaço, o negócio, no início de 1916, era dado como certo por diversos membros da administração do clube. A situação se modificaria quando, em abril, curiosamente na data do aniversário de quatro anos da agremiação, Luiz Suplicy comunica à diretoria que a Companhia Construtora de Santos - através de sua subsidiária Companhia Santista de Habitações Econômicas - havia proposto ao clube fornecer um campo completo, vendendo-o em prestações mensais (PIERIN, 2011, p. 75). Pouco mais de um mês depois do comunicado, o vice-presidente Álvaro de Oliveira Ribeiro informa aos sócios em reunião extraordinária as seguintes considerações sobre as possibilidades aventadas pela diretoria sobre a compra de um terreno para a construção de um campo de jogo. 0 documento abaixo é parte da ata da reunião e encontra-se disponível no centro de documentação localizado na atual sede do clube:

“Valor do terreno da Construtora (Cia. Santista de Habitações Econômicas): 72:000\$000, com 16.000 metros quadrados. Valor do terreno de Oswaldo Sampaio: 40:000\$000, com 18.000 metros quadrados. A venda do terreno de Oswaldo Sampaio depende da anuência dos condôminos - venda sujeita a embargos do condômino que não estiver de acordo. Construtora: O campo será entregue dentro de quatro meses no máximo. Oswaldo: Necessita seis 
meses para despedir os inquilinos, podendo ainda segundo informa o advogado do mesmo, haver desmanda do inquilino, o que demoraria a questão. O terreno da Construtora é alto, setenta centímetros acima no nível da rua, com luz elétrica, água e esgotos, bonde e bairro familiar. O de Oswaldo por sanear e para conseguir o saneamento é necessário abrir valas, sem esgotos, sem luz e bonde muito distante. Construtora: paga -se o terreno em dez anos em prestações mensais de novecentos mil réis e juros de $8 \%$ a $10 \%$ ao ano. O terreno de Oswaldo só terá valor de quarenta contos durante dois anos. Daí em diante será a vontade do mesmo. A opção dará lugar caso o terreno nessa ocasião esteja valorizado e o sr. Oswaldo não sujeitar -se a aceitar o preço combinado e pagar ao clube a importância dispendida na construção das benfeitorias: caso não se possa comprar o campo, o clube terá de pagar (...) 50 anos a quantia de quinhentos mil réis mensais o que importa em dezoito contos de réis. A Construtora ainda empresta ao clube a quantia de trinta contos de réis com juros de $12 \%$ ao ano, pagando em cinco anos e em prestações mensais, para a construção das benfeitorias. Com o sr. Oswaldo não se tem onde haver essa quantia devido as condições atuais da Praça e ao clube, sem fundo de reserva, o que deixará problemática a construção de arquibancadas etc, e até o fim do ano corrente onde será disputado o campeonato? Com a Construtora, com os três primeiros anos, o clube terá gasto a importância de cinqüenta e sete contos de réis. Com o sr. Oswaldo, o clube, nos três primeiros anos, terá de arranjar a quantia de quarenta contos de réis para a compra do campo, mais trinta contos para pagamento das benfeitorias, e, mais doze contos dos aluguéis dos campos, o que soma oitenta e dois contos de réis."

Em menos de duas semanas, no dia 10 de junho de 1916, o presidente Agnello Cícero de Oliveira encerrou as negociações e assinou contrato de compra do terreno e construção do campo de jogo - incluindo aterro, colocação de gramado e ligação com a rede de esgoto e saneamento - com a Companhia Santista de Habitações Econômicas (ver imagens 20 a 22, p. 143 e 144). Interessante notar o destaque dado no documento à existência de água, rede de esgoto, luz elétrica, linhas de bonde e demais serviços urbanos no contrato oferecido pela Companhia, empresa responsável, em parceria com o poder público local, por amplo projeto de urbanização do incipiente bairro depois chamado de Vila Belmiro.

As negociações entre Santos Futebol Clube e a empresa de Simonsen revelam aspectos interessantes do processo de configuração do espaço urbano santista. 
A construção de habitações populares em uma cidade caracterizada por crescimento populacional vertiginoso era tema amplamente discutido desde fins do século XIX. Saturnino de Brito, por exemplo, em texto de 1909 já propunha para Santos a construção de "lares operários destinados às famílias pobres", tendo por objetivos a melhoria das condições de salubridade e o conseqüente combate às epidemias e o "estabelecimento de uma nova ordem moral e social pela elevação correlata dos sentimentos e conduta do proletariado". (BRITO, 1943 , p. 155-56 e p. 162) Na mesma obra, Saturnino indica inclusive as especificações que as moradias populares, destinadas aos trabalhadores, deveriam ter: quarto, cozinha, quintal, gabinete e precisariam ser bem ventilados e servidos por rede de esgoto. Na pedagogia sanitarista de Brito, a conservação da casa e da vida em família seria o lugar primordial de formação de um novo e bom trabalhador.

Na primeira metade da década de 1910, o tema volta à baila por ocasião da fundação da Companhia Construtora de Santos em 1912 e pela criação de uma de suas subsidiárias, a Companhia Santista de Habitações Econômicas, em 1914. Esta última, envolvida diretamente na construção do campo de jogo do Santos Futebol Clube, surgiu, segundo consta do contrato então firmado com a municipalidade, "com o objetivo de construção e revenda de lotes urbanos e construção e exploração de habitações operárias". A Companhia, no entanto, após três anos de contrato - em 1917, portanto - havia construído apenas quatro das quinhentas moradias operárias previstas no acordo com a administração municipal (LANNA, 1996, p. 129). O período coincide com a proposta feita pela empresa ao Santos Futebol Clube para a construção de uma praça esportiva na mesma Vila Operária, posteriormente denominada Vila Belmiro, que deveria ter recebido as habitações destinadas à classe trabalhadora.

Nas palavras de um de seus diretores, em passagem citada por Lanna (1996), a Companhia afirma ter desistido da construção de habitações populares no local devido ao fato de o capital empregado não ter "justa remuneração".

O traçado das linhas de bonde e dos canais de saneamento dos projetos de Saturnino de Brito ia definindo a paisagem dos bairros explorados, loteados e comercializados pela empresa de Simonsen. A ocupação dos novos bairros respondia à lógica de mercado aplicada à habitação. No lugar de moradias populares, confortáveis casas com jardins sendo ocupadas, ainda nas palavras do diretor da Companhia citado anteriormente, por "operários de casaca", típicos elementos da classe média. De um lado, a classe trabalhadora vai sendo empurrada para as adjacências da região central e para os morros, espaços desprovidos, em larga medida, das benesses das reformas urbanas e das obras de saneamento. De outro lado, a expansão do 
capital privado, articulado ao poder público, na exploração e loteamento dos novos bairros que surgiam.

Os estádios de futebol surgiam como desdobramento da expansão e das transformações urbanas, consolidando os espetáculos de futebol como possibilidades de investimentos e de obtenção de lucro.

As relações da Companhia Construtora com o futebol continuariam estreitas. No início da década de 1920, a empresa seria a responsável pela construção da praça esportiva da Associação Atlética Americana, também no bairro da Vila Belmiro (ver imagens 20 e 26, p. 143 e 146). Em reportagem publicada no dia 15 de março de 1925, o jornal $A$ Tribuna relata as festividades de inauguração e afirma:

“Confiada à Companhia Santista de Habitações Econômicas a respectiva construção, o campo da Americana oferece, logo ao primeiro golpe de vista de seu visitante, a mais agradável impressão, pela sua beleza, conforto e segurança, o que vem demonstrar que a empresa a quem foi confiado o trabalho soube desempenhar-se de modo a satisfazer as exigências do esporte. (...) A nova praça de esportes está situada à Rua D. Pedro I, n. 50, em Vila Belmiro, e ocupa uma área de terreno de 130 metros por 97, sendo as seguintes as dimensões do campo: 109,60 metros de comprimento por 72,12 de largura. A arquibancada mede cerca de 40 metros, dispondo, também, de casa para mordomo, botequins para arquibancadas e para gerais, dos vestiários, com alojamentos indispensáveis para 66 jogadores, pavilhão para a imprensa, bilheterias e outras dependências."

As poucas informações existentes no diminuto acervo do clube sobre o contrato estabelecido com a Companhia Santista de Habitações Econômicas indicam semelhanças com a operação realizada anos antes nas negociações da empresa com o Santos Futebol Clube. A Americana, hoje restrita a uma pequena sede social no bairro do Gonzaga (o campo de jogo não existe desde o início dos anos 1950), firmou contrato com a empresa de Simonsen ainda em 1919 em que esta se comprometia a "fazer o aterro e realizar obras de construção das dependências da praça esportiva" do terreno localizado no bairro que, no período, já era conhecido como Vila Belmiro.

A ampliação dos campos de jogo e a ocupação de espaços urbanos pelo futebol evidenciam a apropriação da prática por setores sociais mais diversificados. Essa constatação, 
no entanto, deve ser vista com cuidado. Embora relevante, a popularização dos espetáculos de futebol precisa ser entendida dentro de seus limites, limites esses impostos pela lógica do capital aplicada ao controle dos espaços e pelas barreiras econômicas existentes para a inserção efetiva de determinados setores sociais à vida cotidiana de alguns clubes.

O estádio do Santos Futebol Clube, por exemplo, possuía, em seus primeiros anos, capacidade para pouco mais de dois mil espectadores. No mesmo período, o clube possuía pouco mais da metade desse número em sócios pagantes. Se as mensalidades em equipes como o Hespanha giravam, até o final da década de 1910, em torno de 1\$000 (SILVEIRA, 2002, p. 18) e na Portuguesa, no mesmo período, correspondiam a cerca de $4 \$ 000$ (SILVEIRA e ROGÉRIO, 2017, p. 19), no Santos as mensalidades ficavam entre $8 \$ 000$, nos anos anteriores à construção do estádio, e em $10 \$ 000$, nos anos de construção de sua praça esportiva. Embora a inauguração do estádio, como já citado por Pierin (2011), tenha dado certo impulso ao número de sócios do clube, ela não foi suficiente para que o clube pudesse prescindir de não-sócios pagantes em partidas disputadas em casa pela agremiação.

O ainda acanhado estádio, dividido em uma arquibancada coberta, geralmente ocupada pelos sócios, e uma cerca em volta do campo, ocupado por não-sócios que haviam adquirido ingressos, trazia em sua própria arquitetura e concepção espacial a divisão entre os que podiam pagar por certos espaços e os que deveriam assistir aos espetáculos de maneira adequada à suas condições financeiras (ver imagem 29, p. 148).

A disseminação de praças esportivas dedicadas à prática do futebol nas décadas de 1910 e 1920 teve nas iniciativas de Roberto Simonsen um de seus vetores. Ela, entretanto, não se restringiu às suas ações.

Durante o final do século XIX e início do século XX, a Companhia Docas de Santos exercia forte controle sobre diversas atividades econômicas na cidade, extrapolando as funções meramente portuárias e explorando setores diversificados como pedreiras e serviços urbanos. Um de seus diretores e, posteriormente, superintendente, teve papel fundamental na compreensão das relações entre a exploração de loteamentos urbanos que caracterizaram a cidade no período e a disseminação do futebol.

Ulrico de Souza Mursa, natural de Niterói (RJ), foi um engenheiro civil especializado em hidráulica, fundador e funcionário de carreira da Companhia Docas de Santos. Durante a juventude, Ulrico Mursa estudou engenharia em três universidades alemãs - Karlsruhe, Hannover e Braunschweig. Na volta, com pouco menos de 30 anos de idade, participou da construção e modernização do porto de Santos, tornando-se rapidamente superintendente da empresa. A década de 1890, justamente a primeira de Mursa como diretor da Docas, marca o 
início dos loteamentos visando a ocupação de espaços fora do perímetro da região central da cidade de Santos. Como já abordado anteriormente, à expansão da rede de transportes urbanos, os loteamentos eram explorados pela iniciativa privada, muitos deles comprados por uma crescente camada de servidores públicos, negociantes ou funcionários qualificados dos quadros da Companhia Docas (HONORATO, 1997, p. 88).

A dinâmica de especulação em torno dos loteamentos geralmente respondia à mesma lógica: o terreno era adquirido por particulares que se beneficiavam financeiramente da urbanização de seus terrenos. Esses particulares eram responsáveis por alguns serviços básicos de melhoramentos - especificados através de contratos com a municipalidade - e recebiam honorários do poder público em decorrência dos investimentos realizados. Além disso, lucravam com a venda de moradias, exploração do comércio local e revenda de terrenos no perímetro do lote adquirido. O bairro atualmente chamado de Macuco, por exemplo, surgiu nesse contexto. As terras do Macuco, próximas ao cais do porto, pertenciam ao Tenente José Apolinário da Silva, marido da dona Luiza Macuco. Suas terras foram divididas entre seus herdeiros, os quais cederam à Prefeitura para abertura de novas ruas. Além disso, lotearam quadras e construíram residências para venda na região próxima à Avenida Conselheiro Nébias (SANTOS, 1937, p. 55).

Ulrico Mursa também se encaixava nesse perfil: segundo documentos da Prefeitura Municipal de Santos, o então superintendente adquiriu terrenos em cinco regiões da cidade, algumas ainda não caracterizadas como bairros. A localização exata desses terrenos não está especificada, exceção feita a um terreno no bairro do Paquetá.

O terreno de Mursa no Paquetá deu início ao seu vínculo mais estreito com o futebol. Em 1914, o engenheiro firmou contrato de cessão do espaço ao Brasil Futebol Clube - clube criado por funcionários da Companhia Docas -, fundado no ano anterior. O clube recém-criado construiu ali, mais especificamente na Avenida Conselheiro Nébias nas proximidades da região portuária, seu primeiro campo de jogo, utilizado até o princípio da década seguinte não apenas pelo Brasil, mas por grande parte das agremiações santistas do período. Poucos anos depois, Ulrico Mursa seria também responsável pela concessão e regularização do terreno que hoje recebe estádio com seu nome. Nas proximidades da Santa Casa de Santos, o espaço cedido por Mursa em 1919 - e, segundo registros do clube, já utilizado de forma irregular pela agremiação desde o ano anterior - seria utilizado para a instalação do campo da Associação Atlética Portuguesa. Nos poucos documentos existentes sobre a concessão - acessíveis no acervo mantido pela Fundação Arquivo e Memória de Santos em seu Arquivo Permanente -, 
existe a indicação de que Mursa pretendia "proporcionar lazer para os habitantes da cidade, em especial os de origem portuguesa".

O estádio da Associação Atlética Portuguesa (ver imagem 31, p. 149) foi inaugurado em dezembro de 1920 em partida da agremiação contra a equipe do Palestra Itália da cidade de São Paulo.

A disseminação de praças esportivas acompanhava o ritmo do desenvolvimento urbano da cidade. Às largas avenidas, canais, linhas de bonde (ver imagem 27, p. 147) e demais serviços urbanos somavam-se agora os estádios de futebol e o crescente público que para eles afluía.

Seja para o estádio do Brasil Futebol Clube, na larga e pioneira Avenida Conselheiro Nébias através do bonde elétrico de número cinco, seja para a praça esportiva do Santos Futebol Clube, nas proximidades do canal de saneamento de número dois através do bonde 27, seja para o estádio Ulrico Mursa da Portuguesa Santista, em frente ao canal de número um idealizado por Saturnino de Brito através do bonde dezessete, centenas de pessoas circulavam pelos caminhos da cidade a cada partida de futebol, criando novas redes de sociabilidade e um novo modo de viver a urbanidade.

As praças esportivas de fins dos anos 1910, desdobramento das reformas urbanas iniciadas ainda na transição do século XIX para o XX, marcariam a consolidação de certa ideia de modernidade e pujança associadas ao espaço urbano santista. Saneada, expandida, higienizada, civilizada. À cidade das praias, canais, porto, empresas, circulação de capital, o seu avesso: entre 1919 e 1920 estouram na cidade duas grandes greves. No primeiro, treze categorias entram em greve em decorrência de paralisação deflagrada no porto por funcionários da Companhia Docas. No segundo, canteiros, entre eles muitos a serviço da Companhia de Simonsen, cruzam os braços. Prisões, invasões de sindicatos, demissões de trabalhadores, deportações.

Falta de moradia, pobreza, segregação sócio-espacial.

À proliferação de times, estádios e espetáculos de futebol, a cidade constituída na saca de café, no saco de cimento, na ponta da picareta, no suor escorrendo pela testa.

Na luta e no lúdico.

Prática social e cultural fundamental na compreensão das tensões entre capital e trabalho, o futebol constituiu elemento primordial de articulação na disputa pelos sentidos da cidade. 


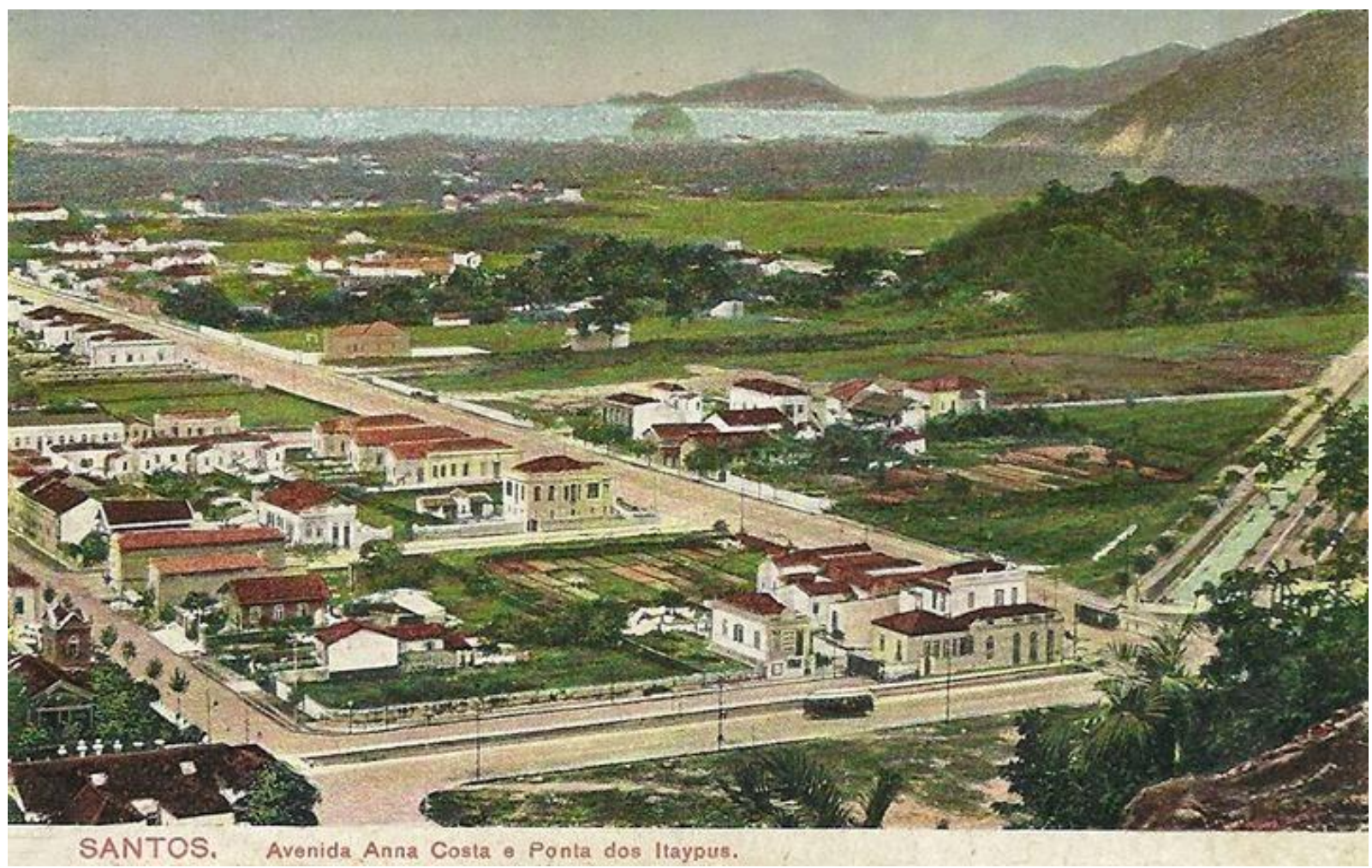

Imagem 1: Avenida Ana Costa, 1907. Fonte: Fundação Arquivo e Memória de Santos

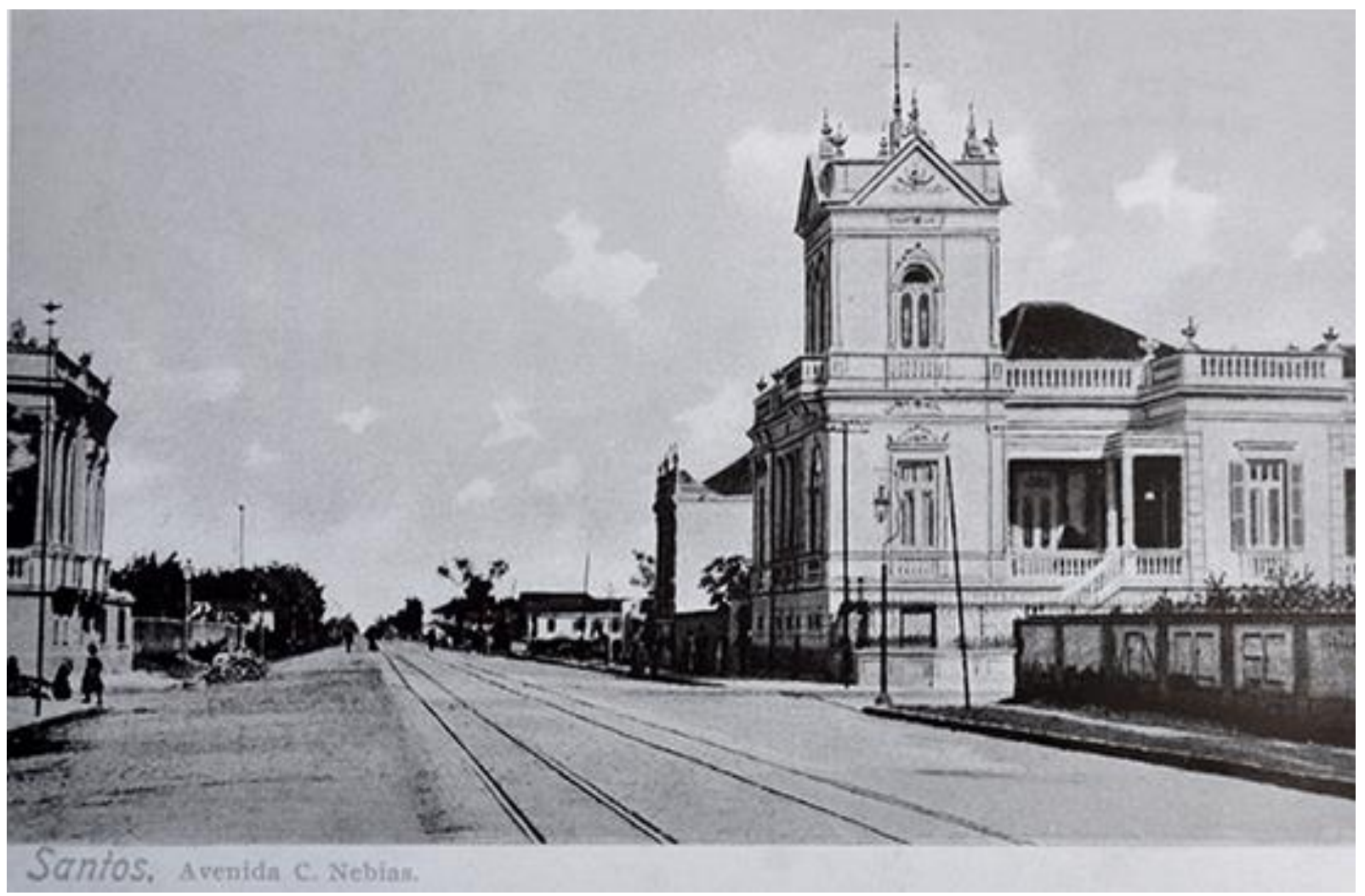

Imagem 2: Avenida Conselheiro Nébias, 1898. Fonte: Fundação Arquivo e Memória de Santos 


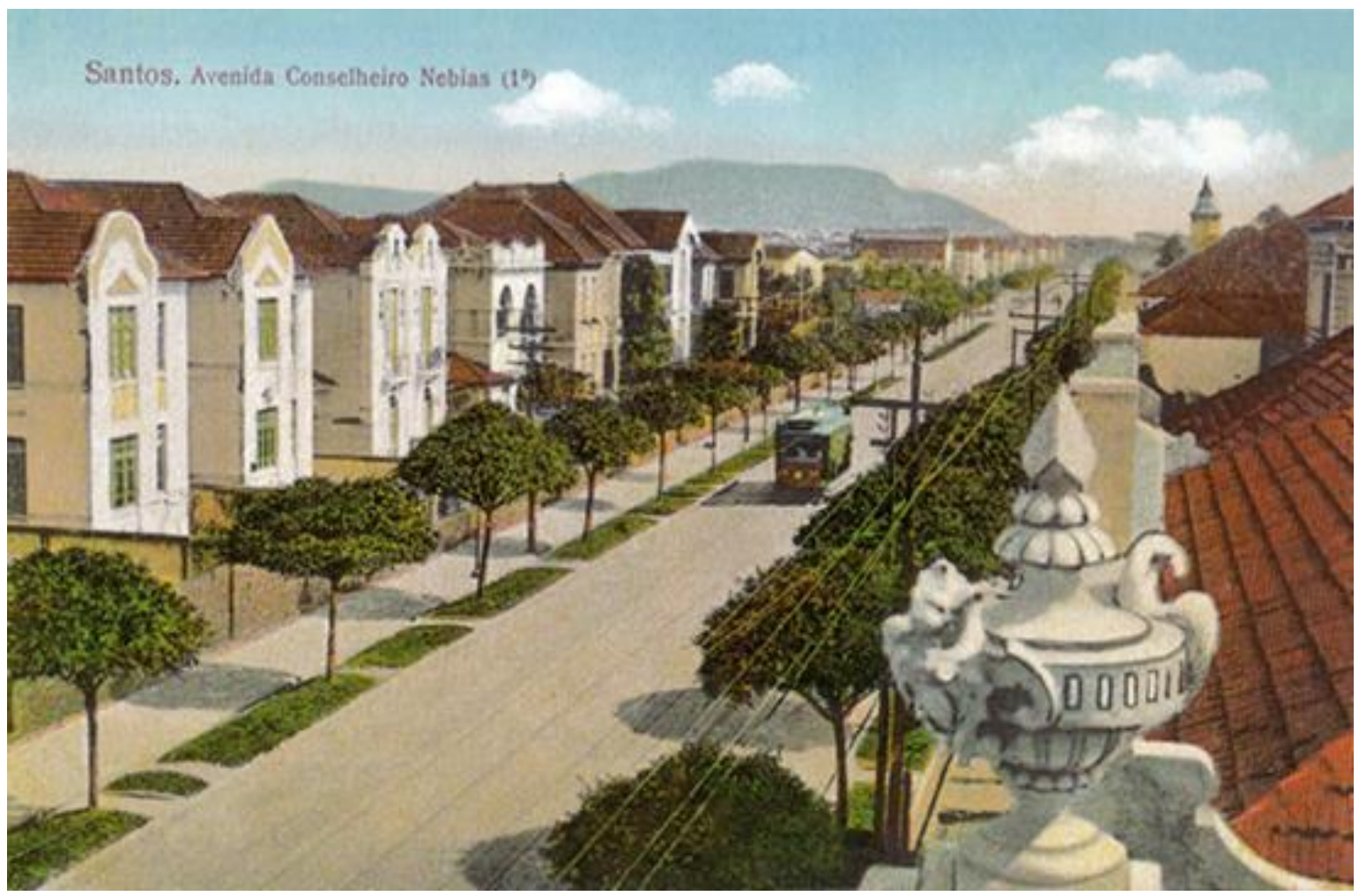

Imagem 3: Cartão Postal, Avenida Conselheiro Nébias, 1913. Fonte: Fundação Arquivo e Memória de Santos

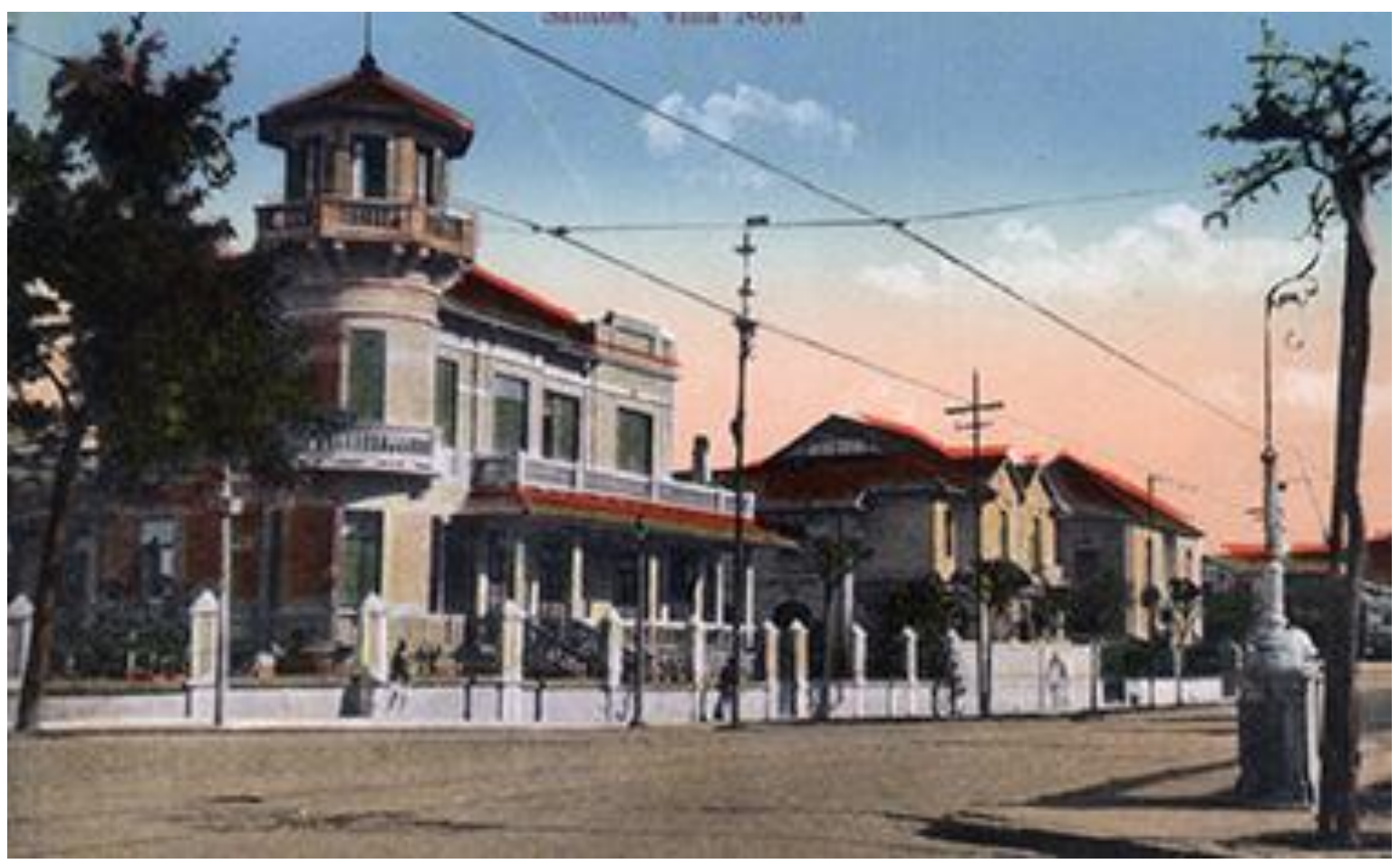

Imagem 4: Sede do Clube XV, Avenida Conselheiro Nébias, 1902. Fonte: Fundação Arquivo e Memória de Santos. 


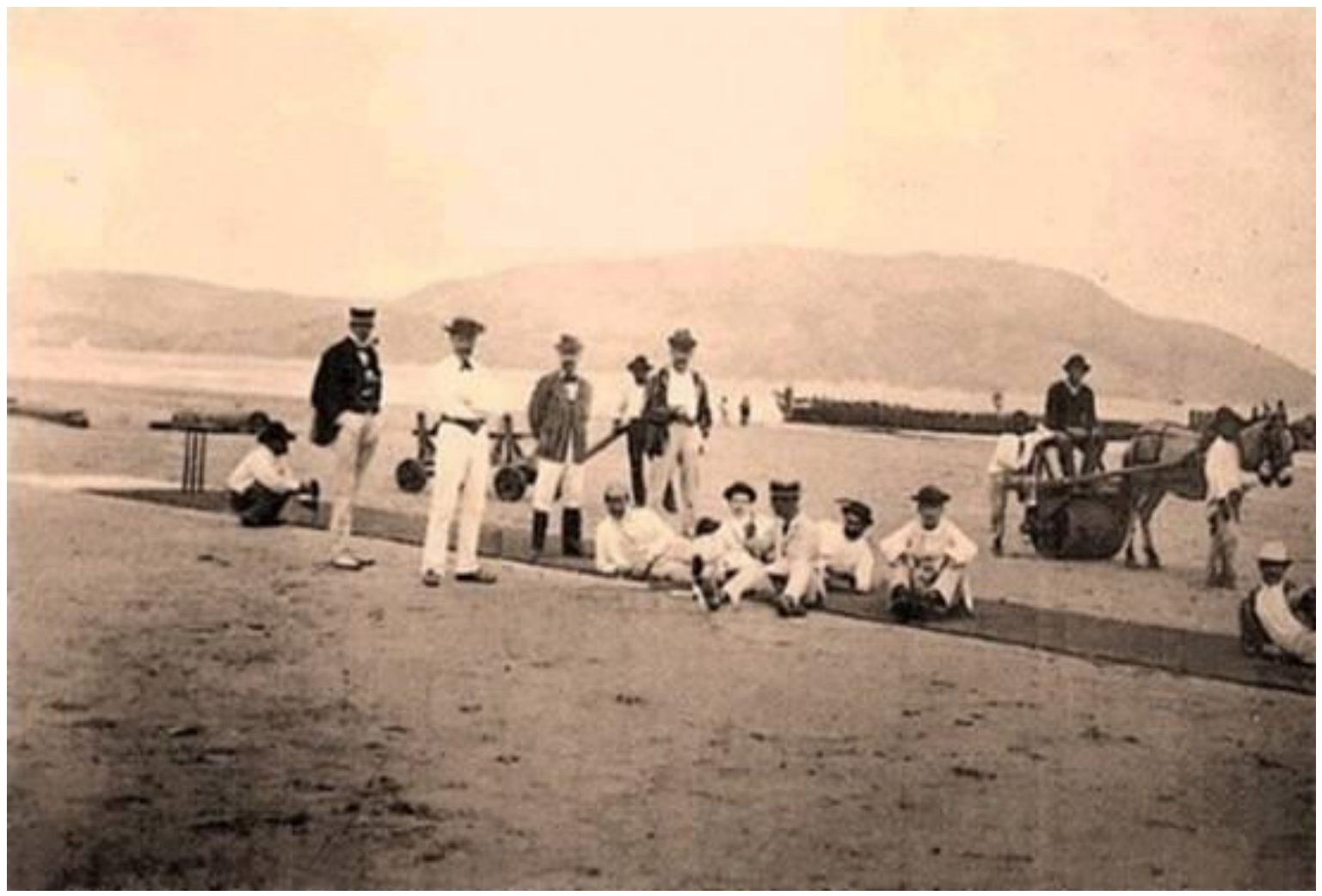

Imagem 5: Partida de Cricket, Clube dos Ingleses, 1897. Fonte: Acervo Santos Athletic Club

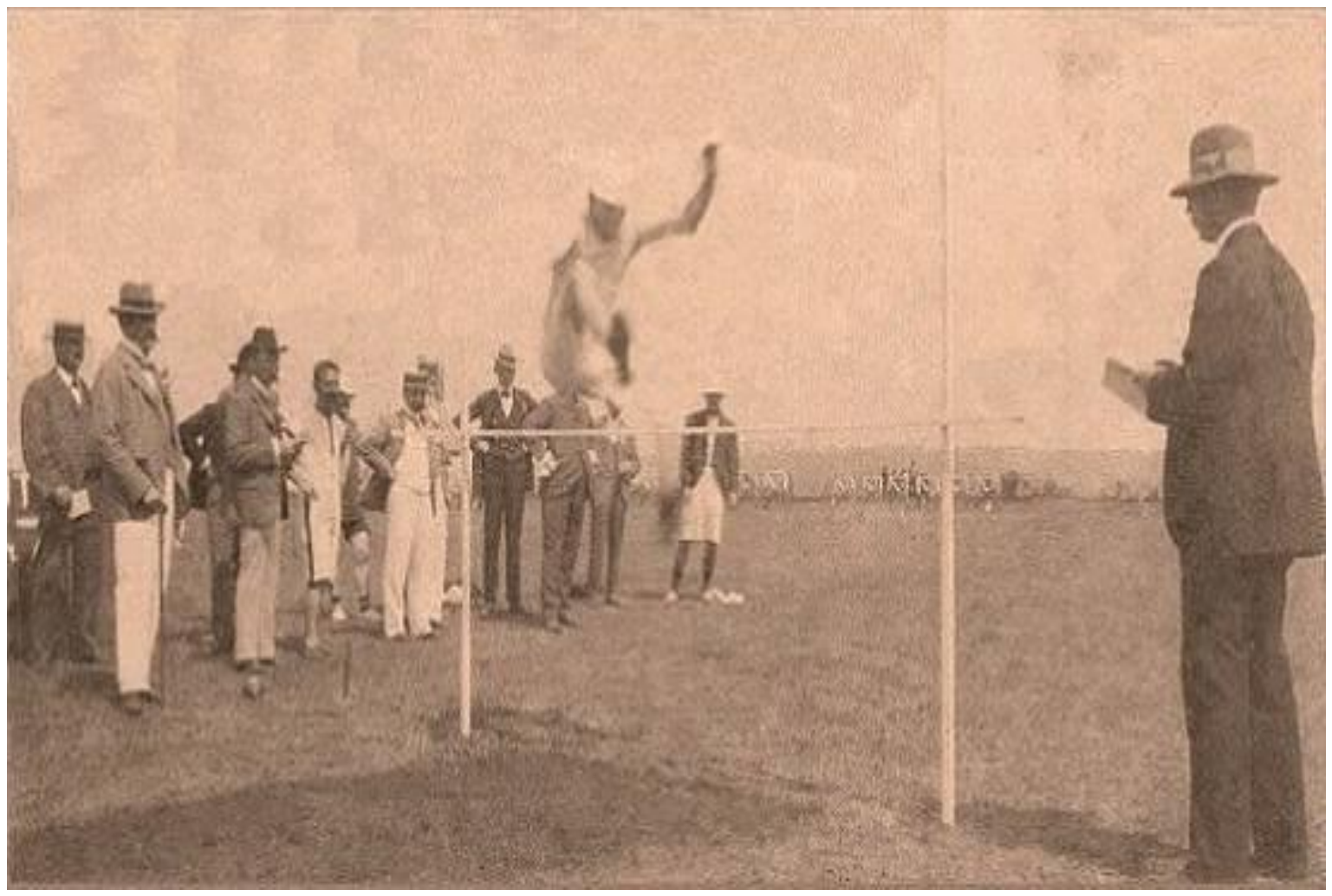

Imagem 6: Sportiva Annual, Prova de Salto, Clube dos Ingleses, 1905. Fonte: Acervo Santos Athletic Club 


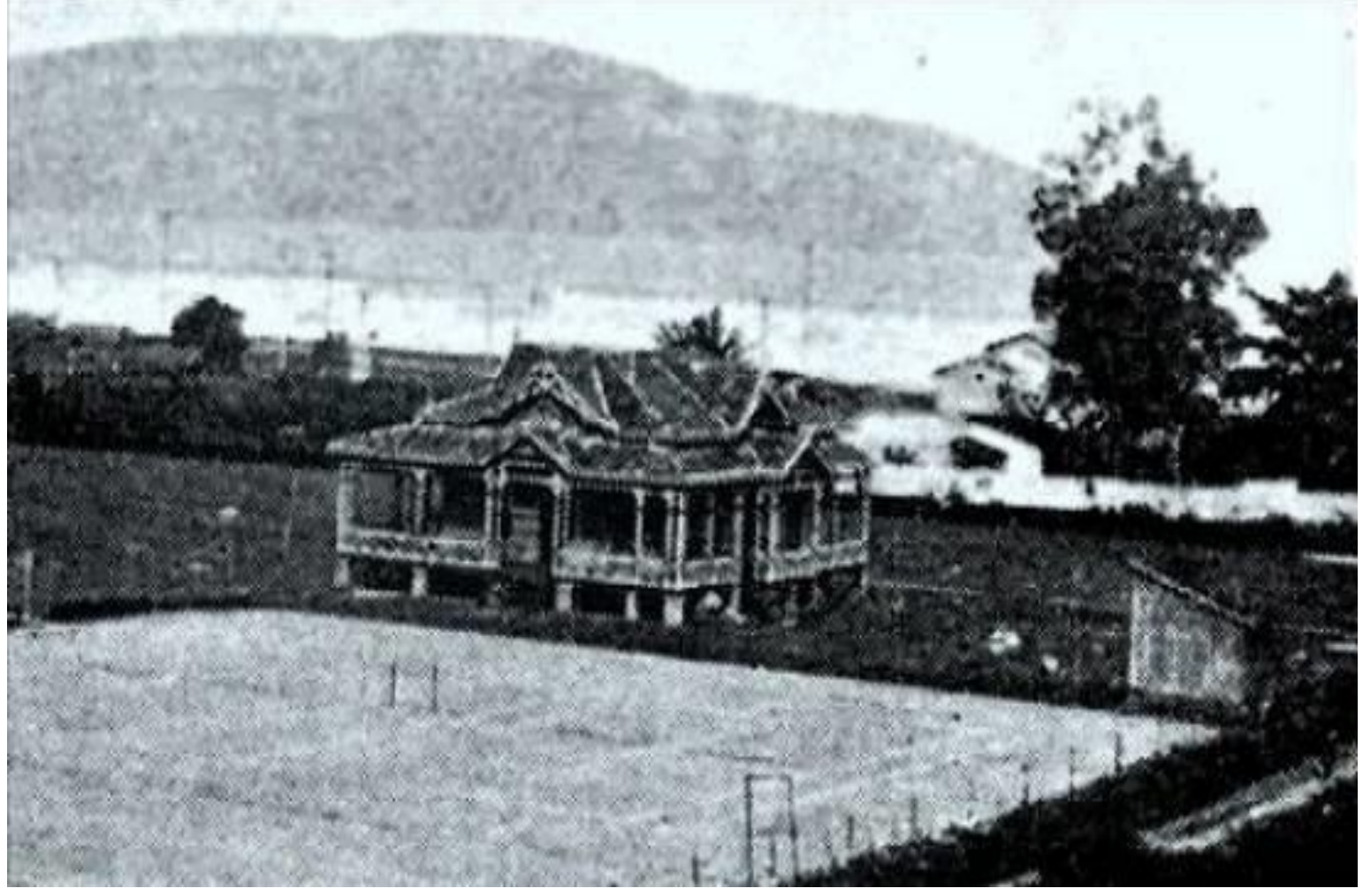

Imagem 7: Sede Social do Clube dos Ingleses, 1908. Fonte: Acervo Santos Athletic Club

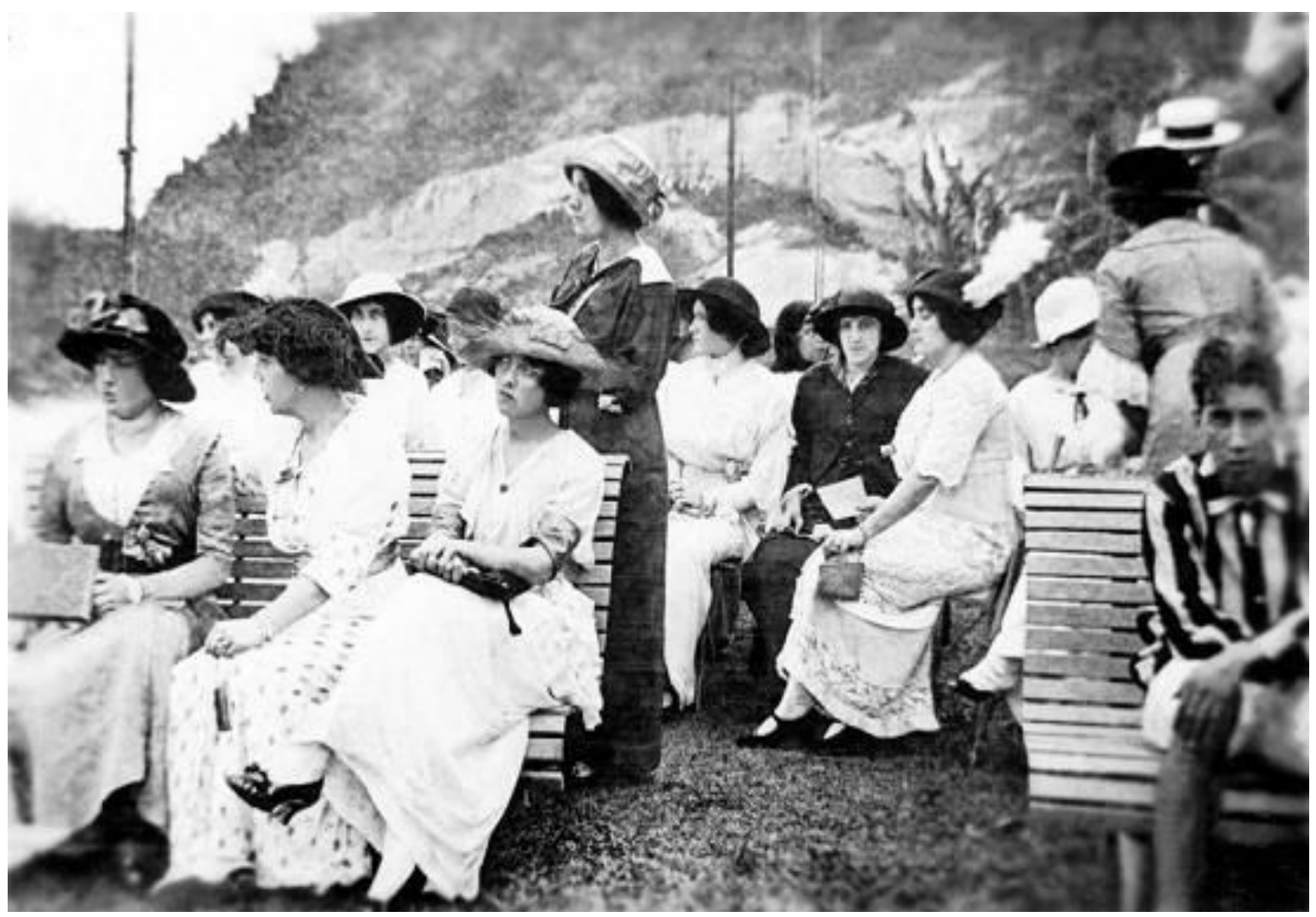

Imagem 8: Sócios do Clube dos Ingleses, 1912. Fonte: Acervo Santos Athletic Club 


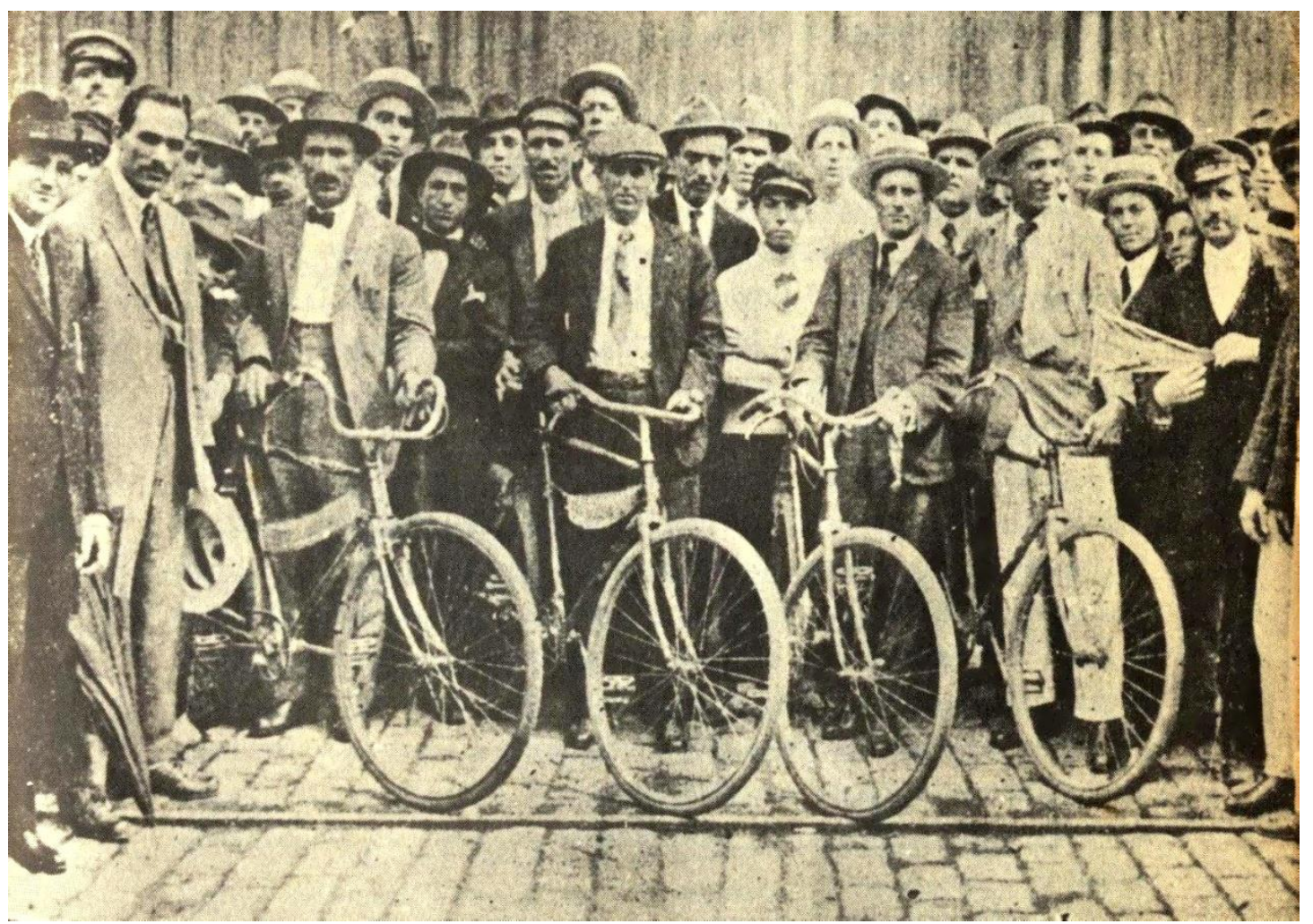

Imagem 9: Membros do Velo Clube, Década de 1900. Fonte: Fundação Arquivo e Memória de Santos

Club internacional de regatas

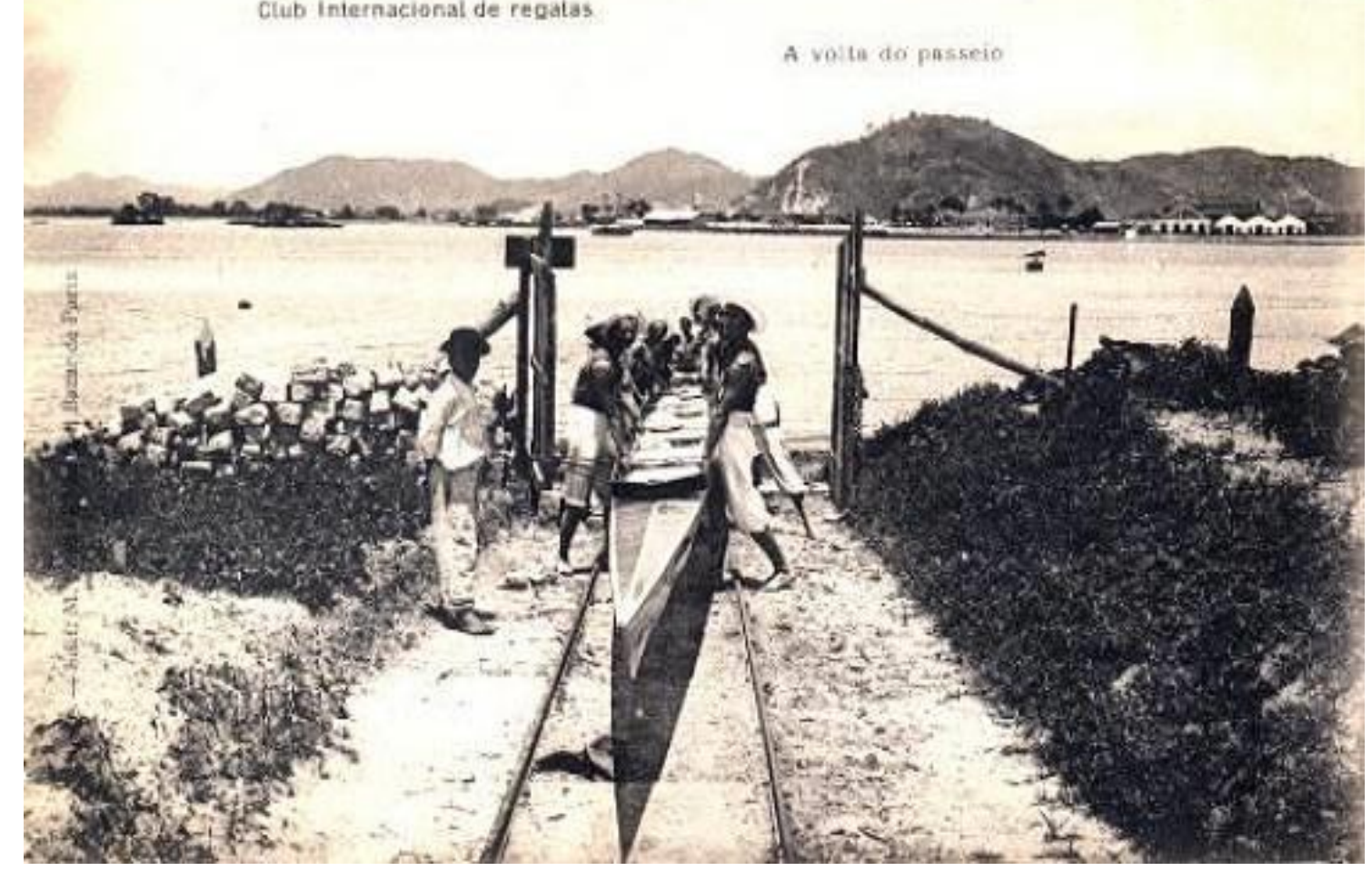

Imagem 10: Clube Internacional de Regatas, 1904. Fonte: Fundação Arquivo e Memória de Santos 


\section{Club Internacional de Regatas}

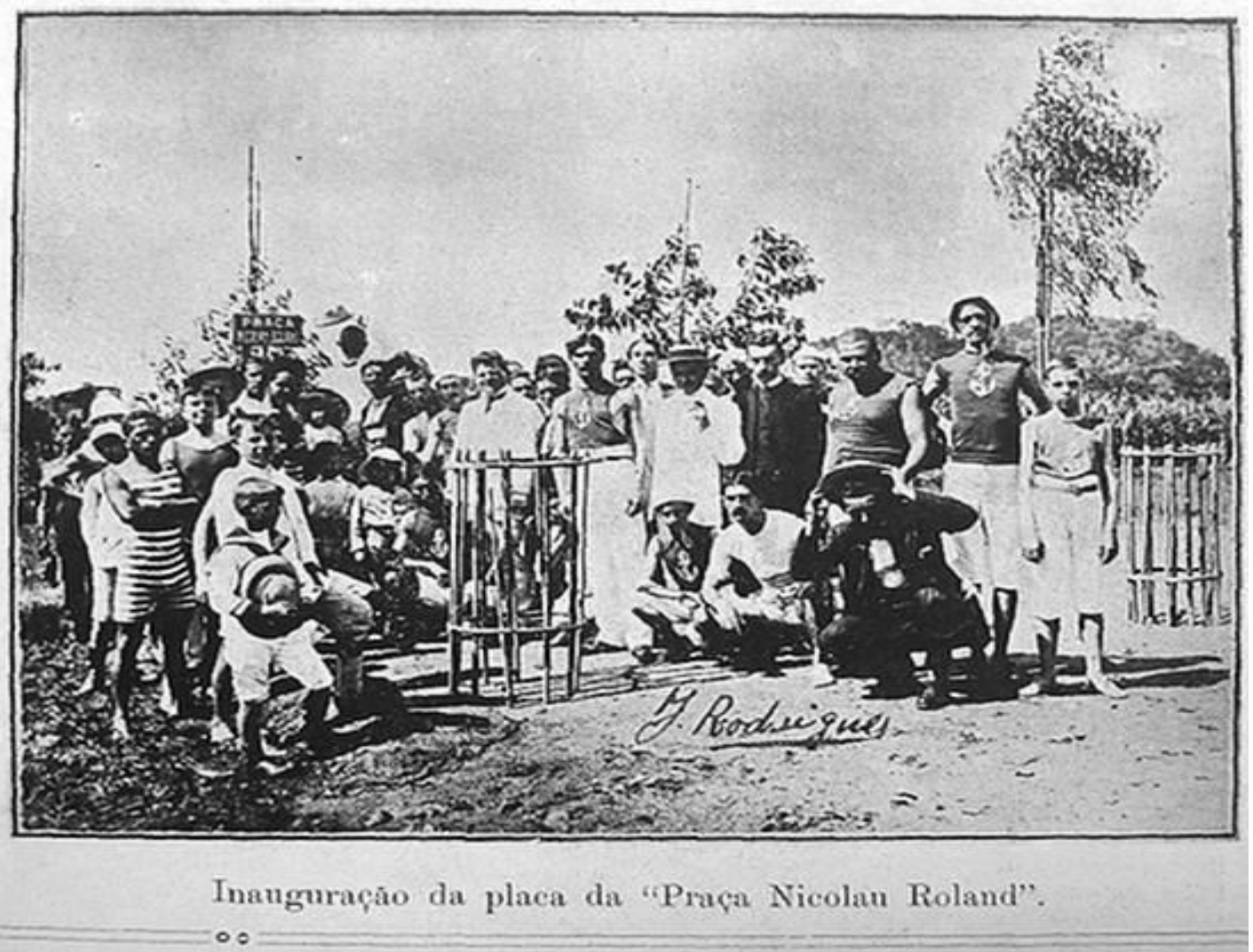

Imagem 11: Clube Internacional de Regatas, 1904. Fonte: Fundação Arquivo e Memória de Santos

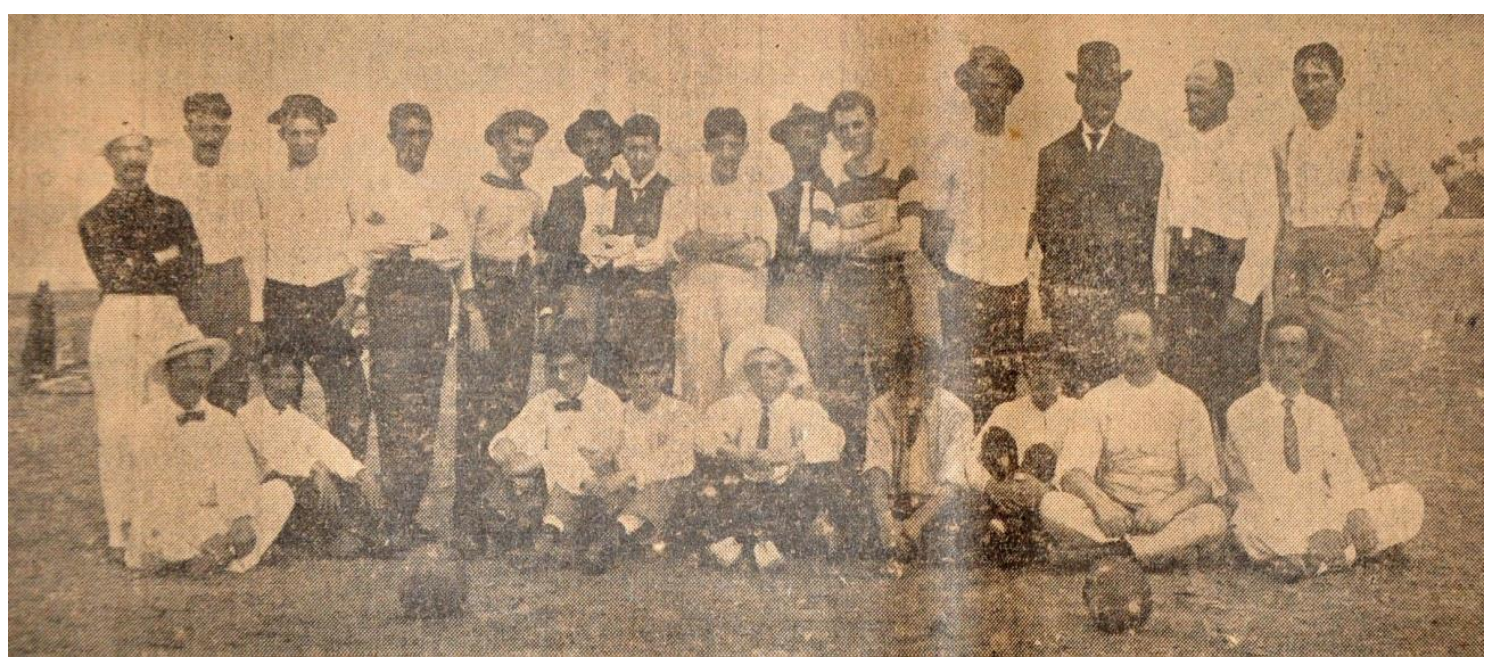

Imagem 12: Integrantes da primeira partida oficial de futebol disputada em Santos, Praia do Embaré, 1902. Fonte: Museu De Vaney 


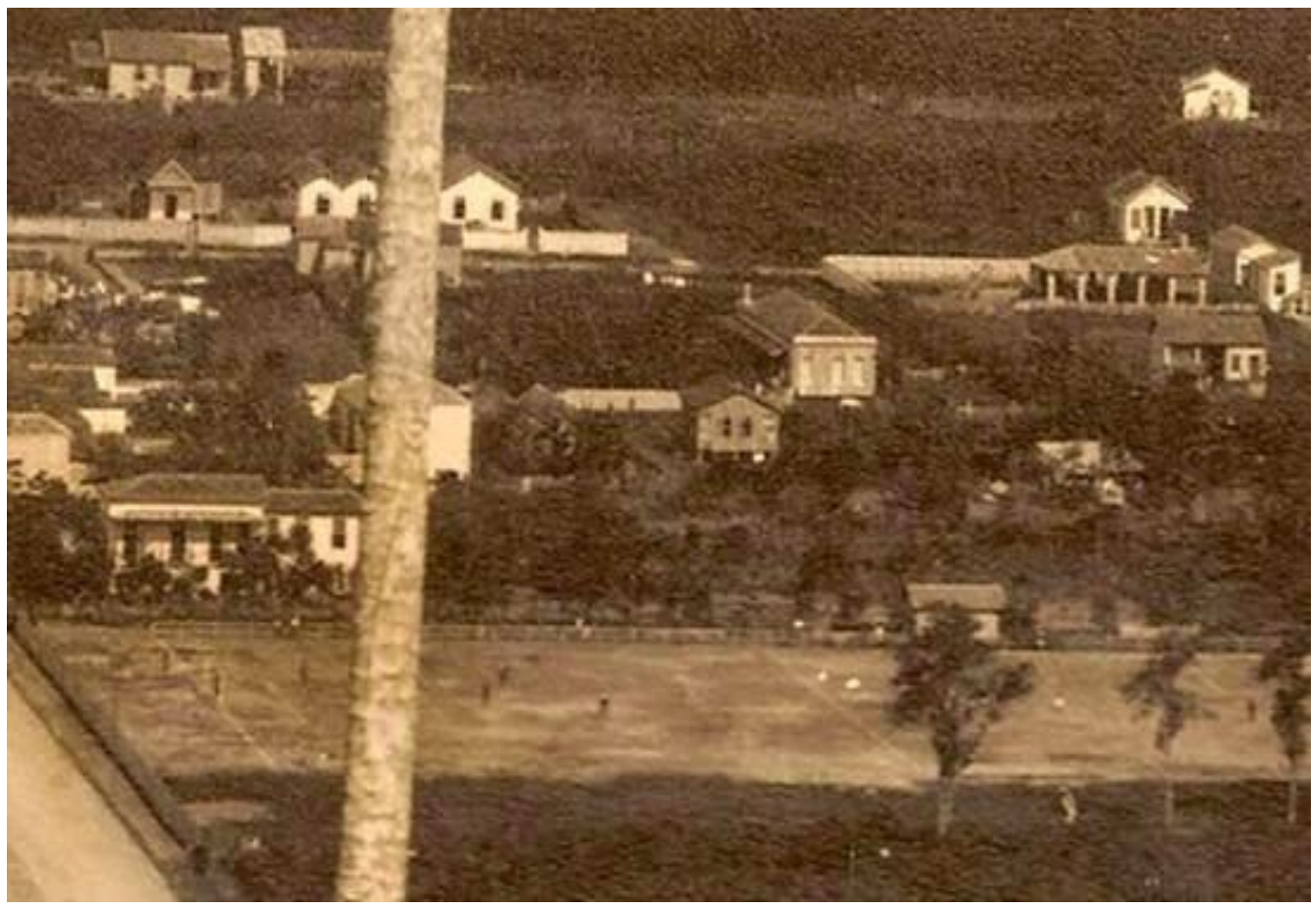

Imagem 13: Campo de Futebol da Avenida Ana Costa, 1907. Fonte: Museu De Vaney

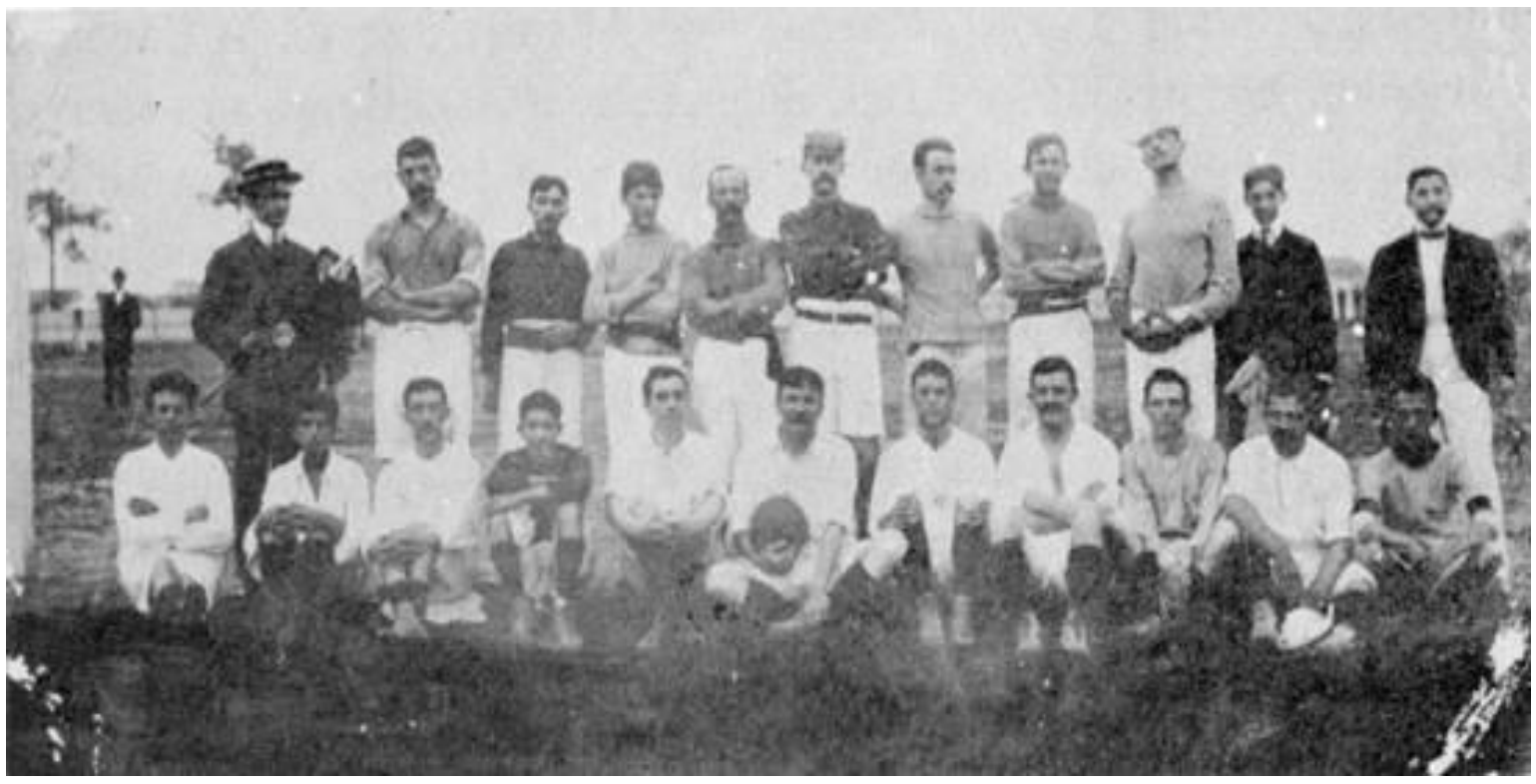

Imagem 14: Time de Futebol do Internacional, 1905. Fonte: Museu De Vaney 


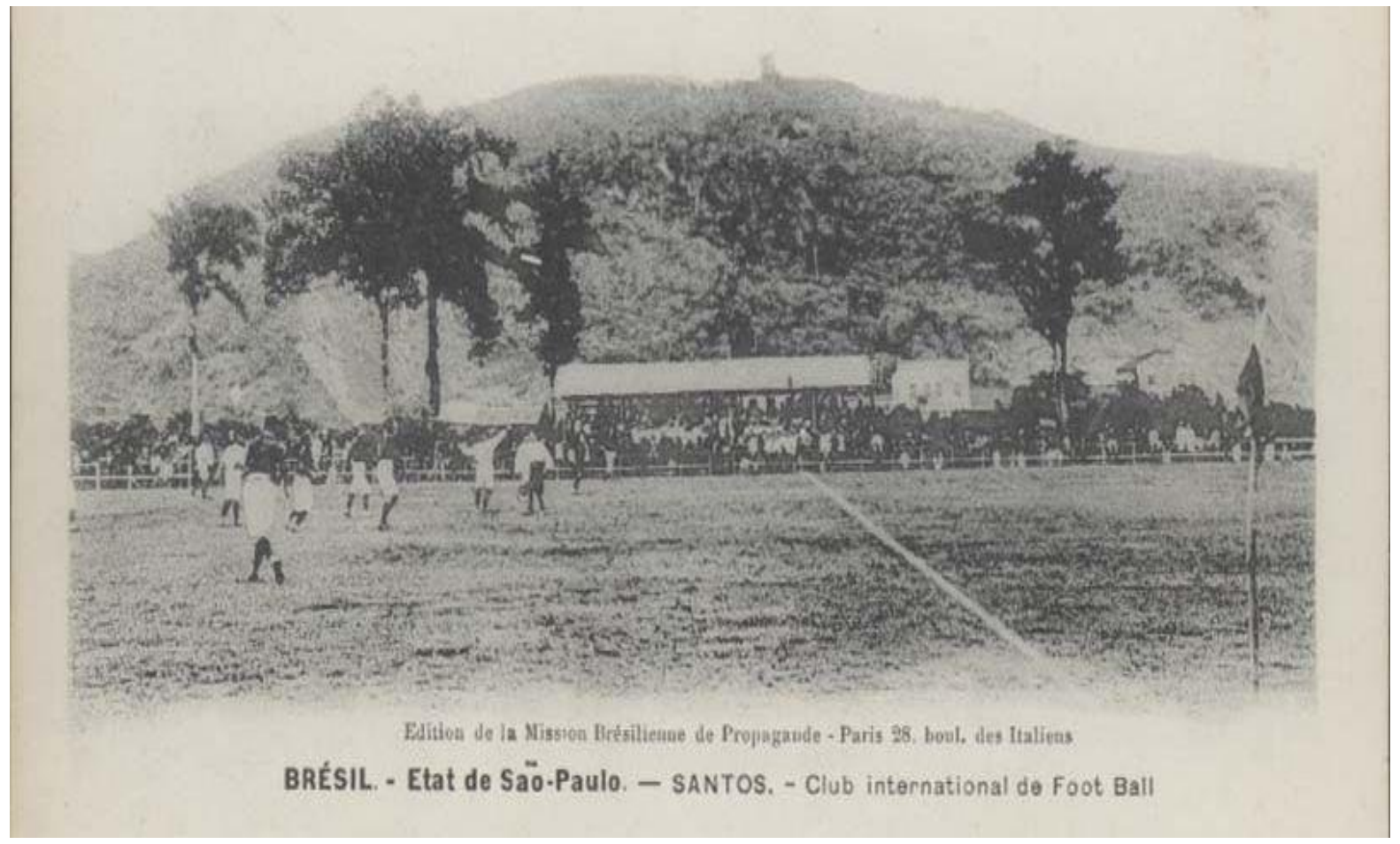

Imagem 15: Santos Futebol Clube contra Santos Athletic Club, Campo da Avenida Ana Costa, 1912. Fonte: Centro de Memória Santos Futebol Clube

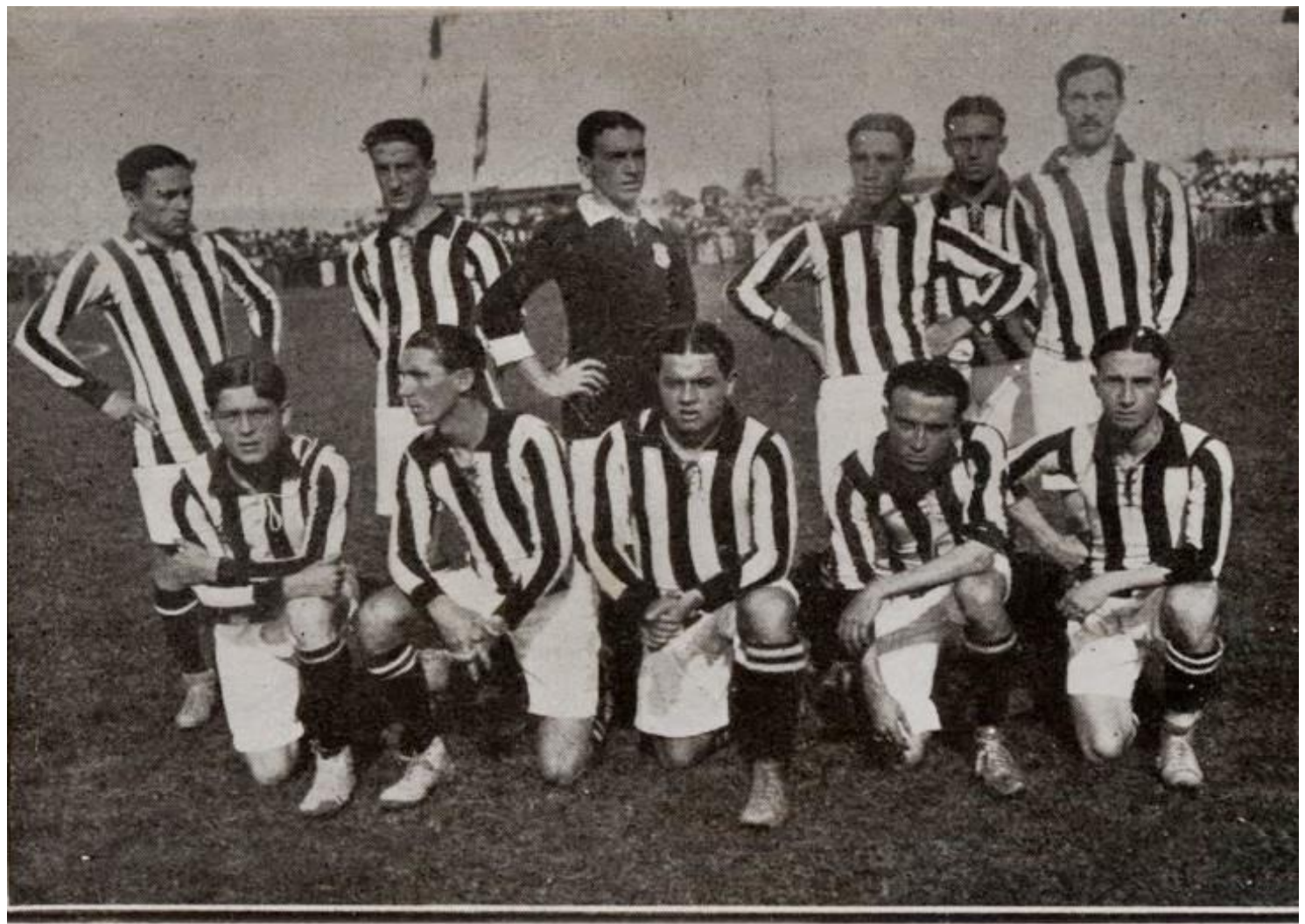

O temivel team do "Santos Foot-ball Club"

Imagem 16: Equipe do Santos Futebol Clube, 1917. Fonte: Centro de Memória Santos Futebol Clube 


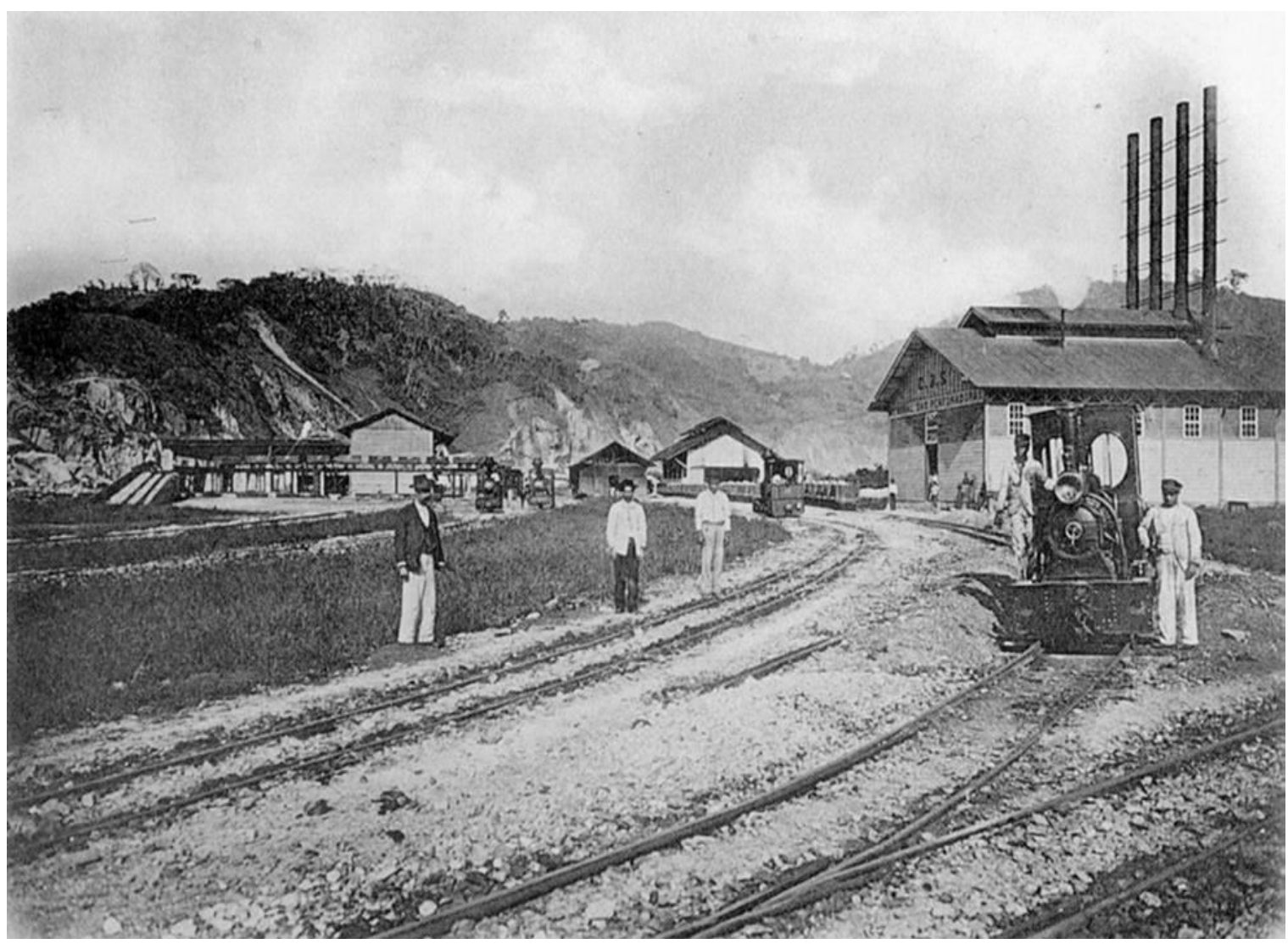

Imagem 17: Pedreira do Jabaquara, Década de 1910. Fonte: Acervo Codesp

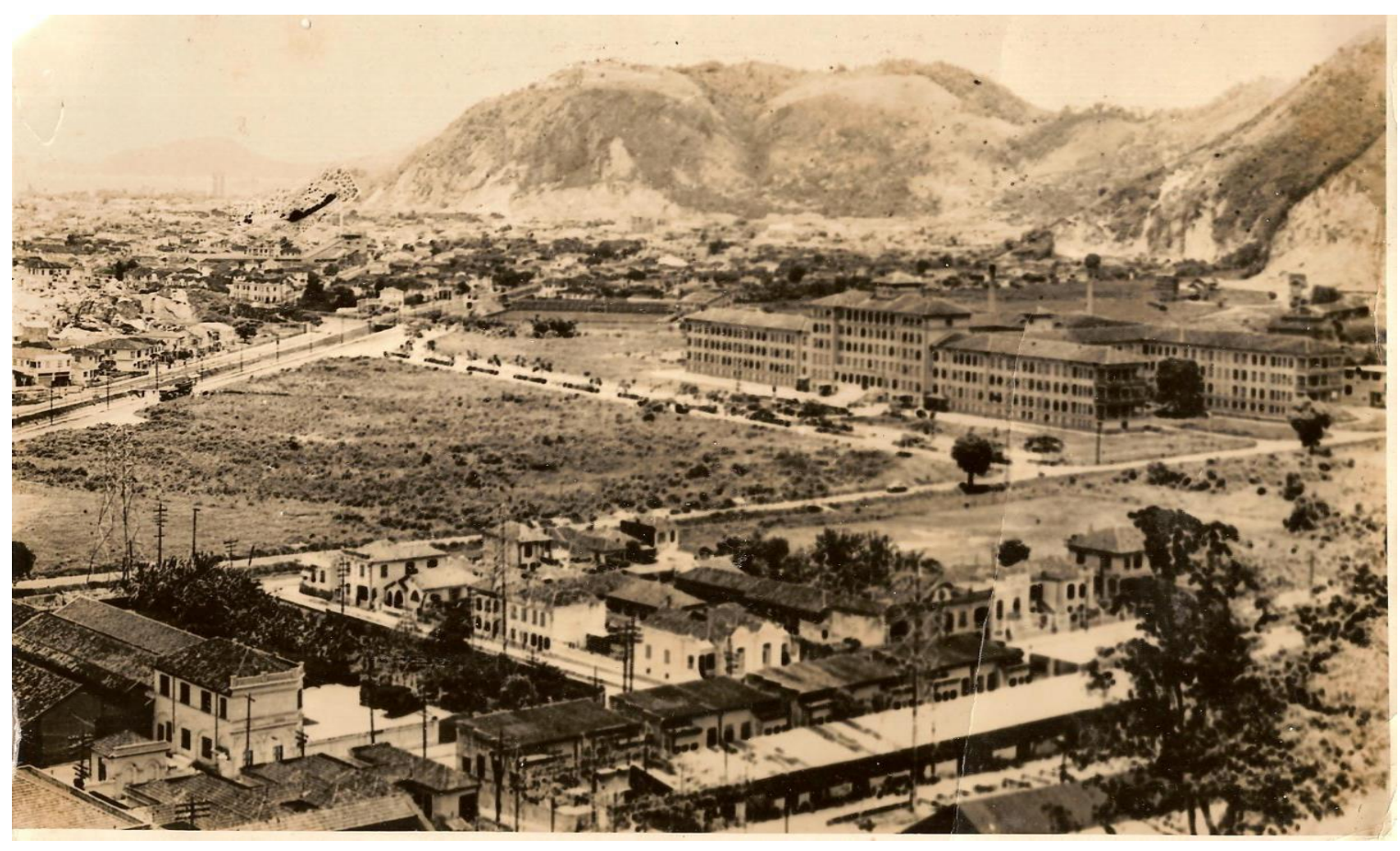

Imagem 18: Bairro do Jabaquara (confluência dos canais 1 e 2 onde seria construído o Estádio Ulrico Mursa), Década de 1910. Fonte: Fundação Arquivo e Memória de Santos 


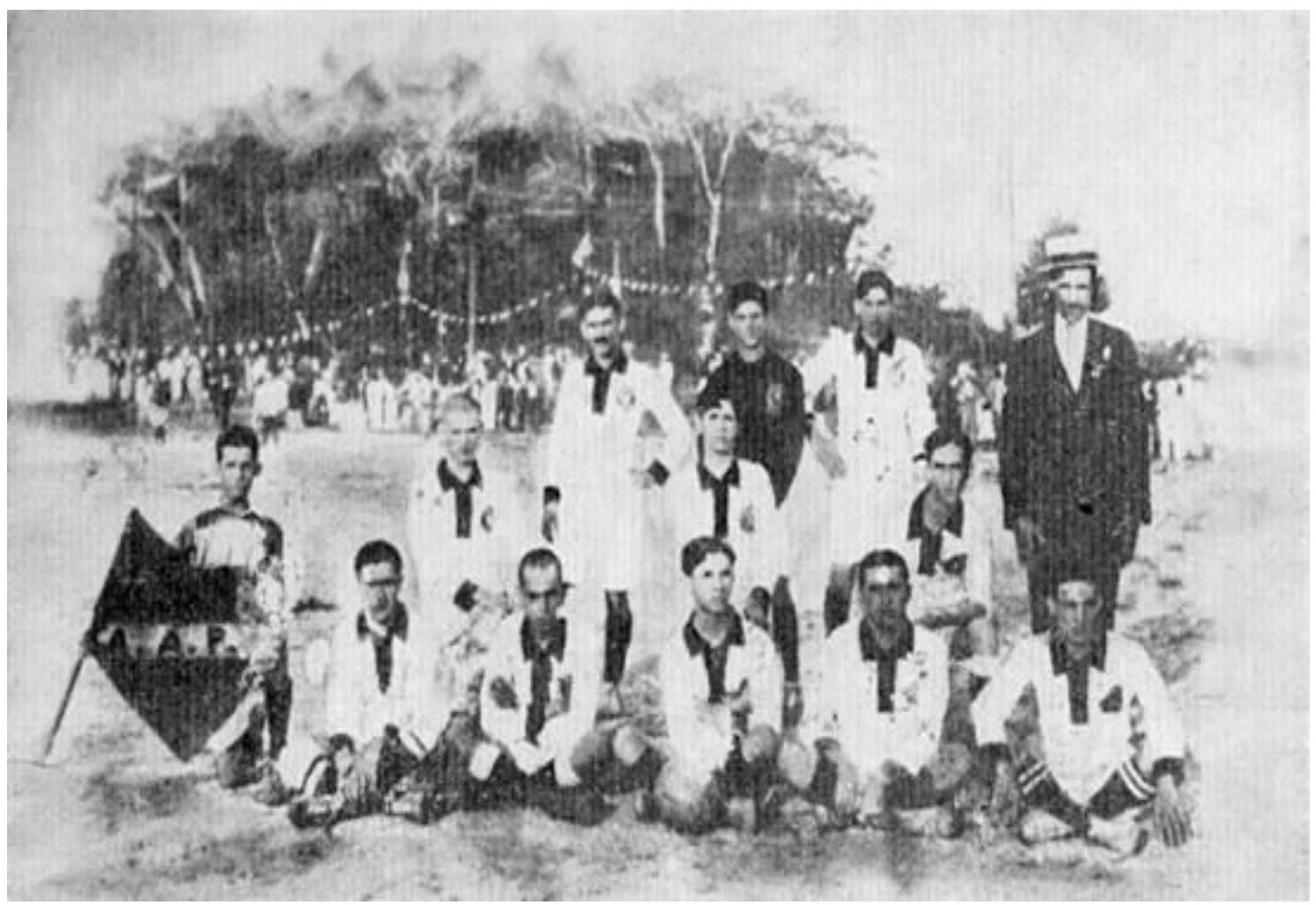

Imagem 19: Equipe da Associação Atlética Portuguesa, 1917. Fonte: Acervo da Associação Atlética Portuguesa.

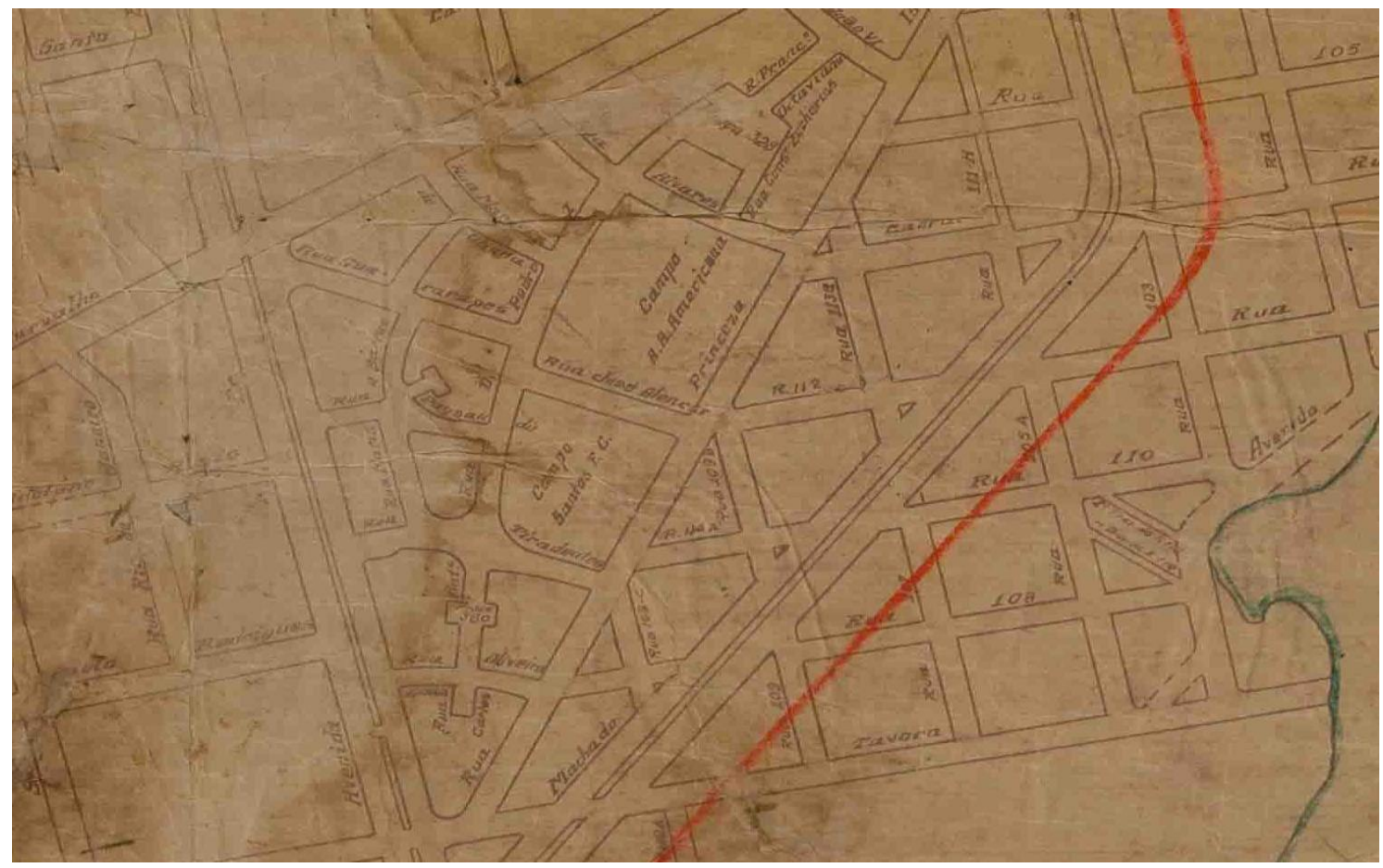

Imagem 20: Planta do Bairro da Vila Belmiro (com as especificações dos locais dos estádios de Santos Futebol Clube e Associação Atlética Americana), sem data. Fonte: Fundação Arquivo e Memória de Santos. 


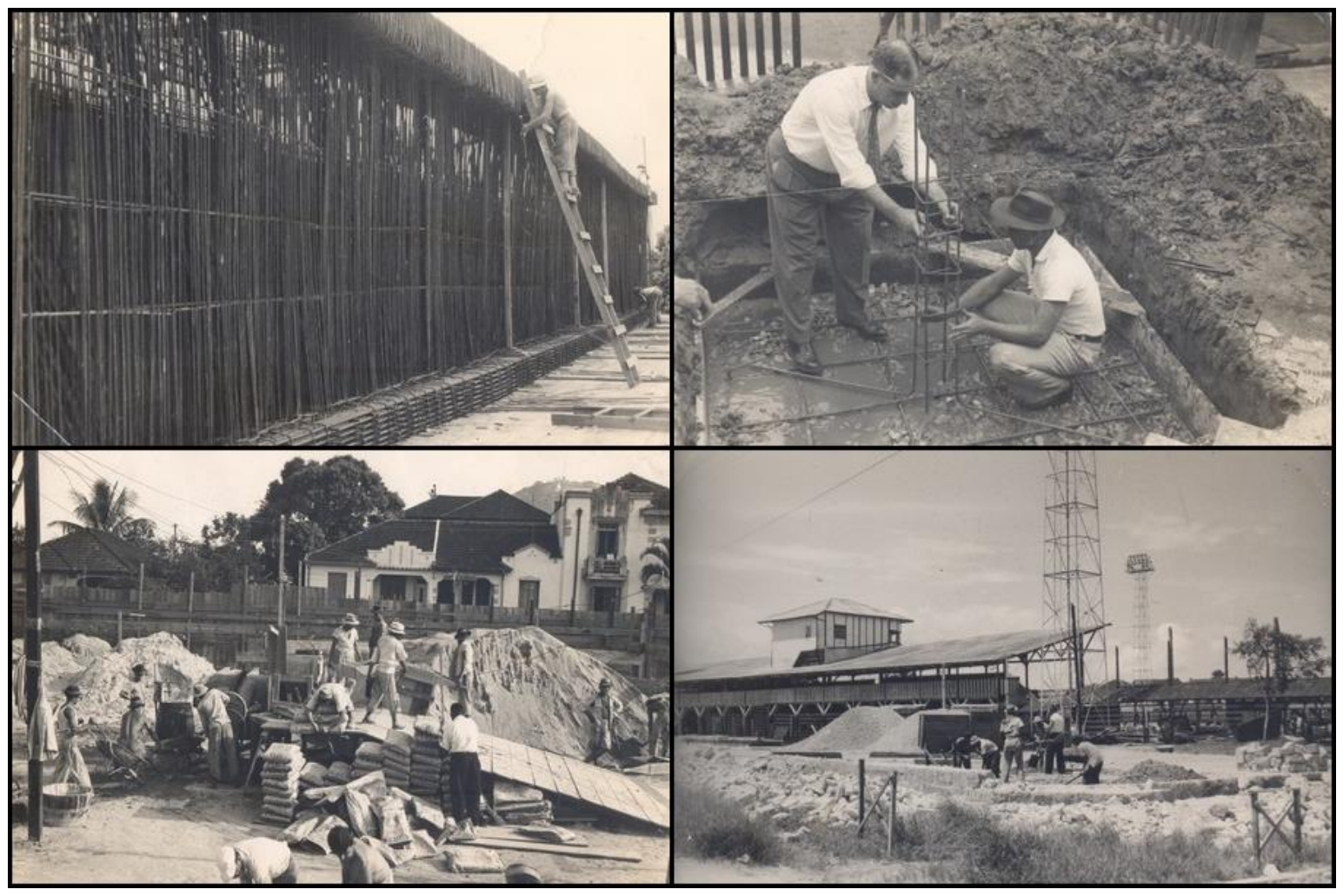

Imagem 21: Construção da Praça de Esportes do Santos Futebol Clube, sem data. Fonte: Centro de Memória do Santos Futebol Clube.

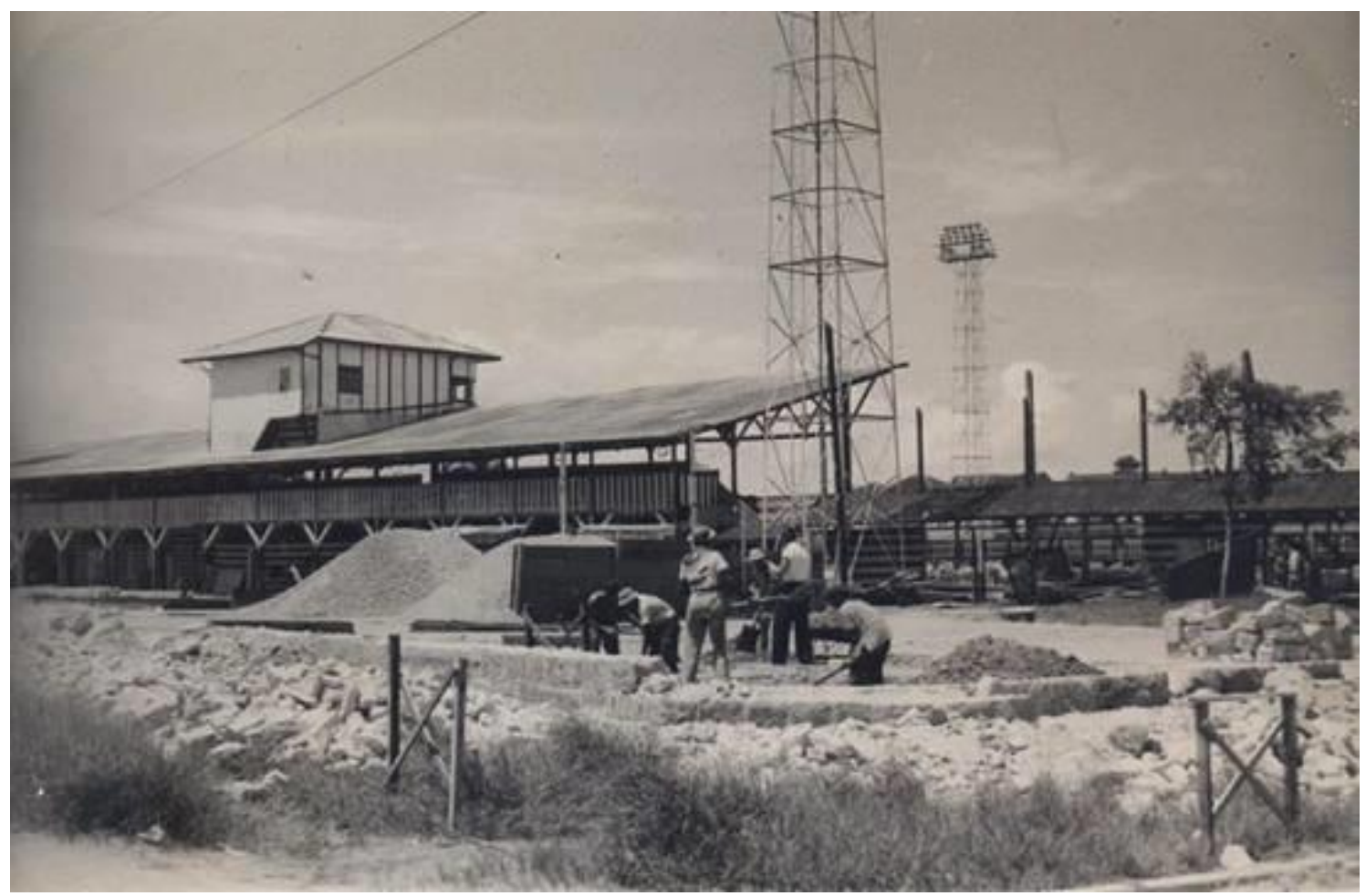

Imagem 22: Construção da Praça de Esportes do Santos Futebol Clube, sem data. Fonte: Centro de Memória do Santos Futebol Clube. 


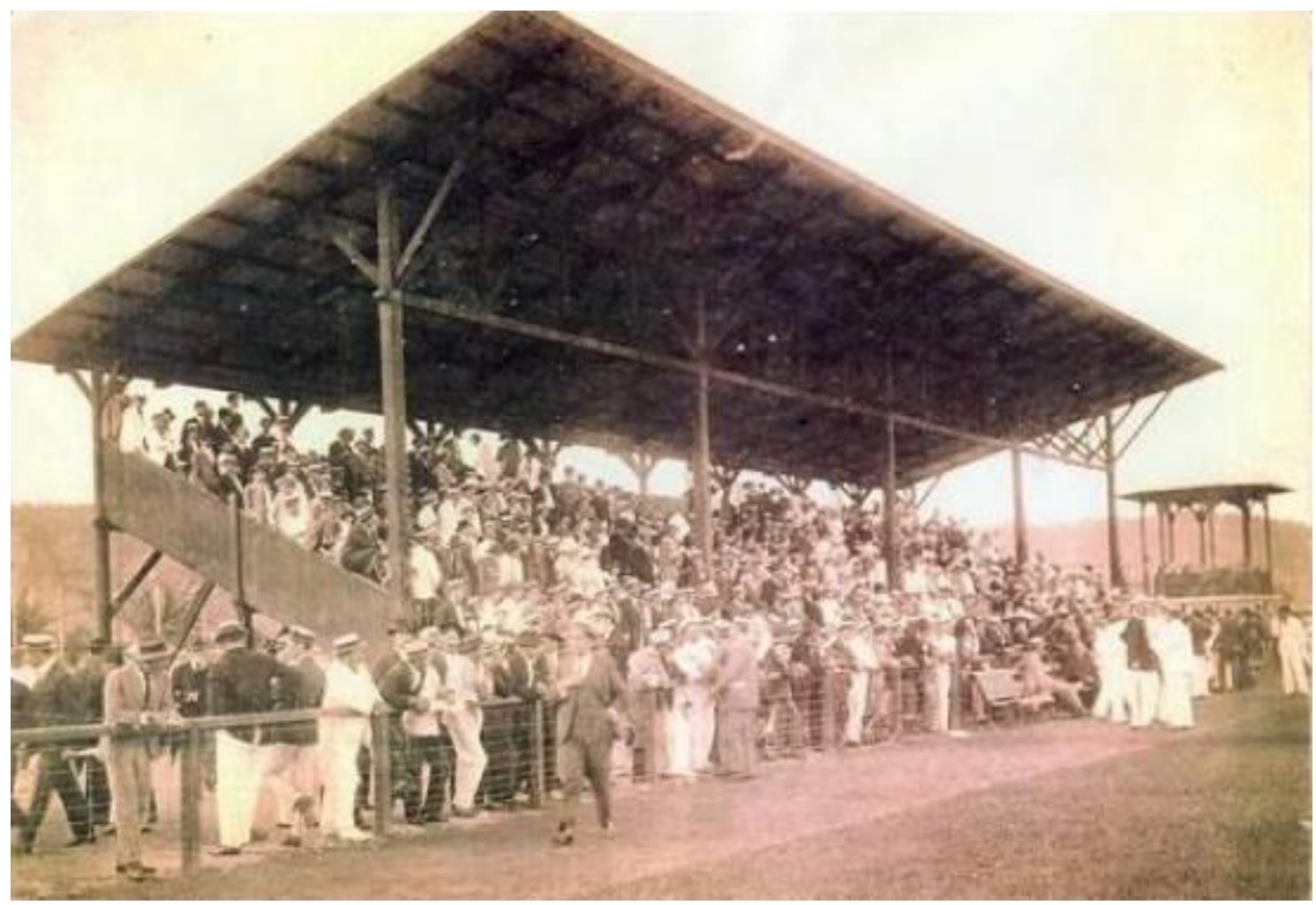

Imagem 23: Estádio do Santos Futebol Clube (atual Vila Belmiro), 1916. Fonte: Centro de Memória do Santos Futebol Clube.

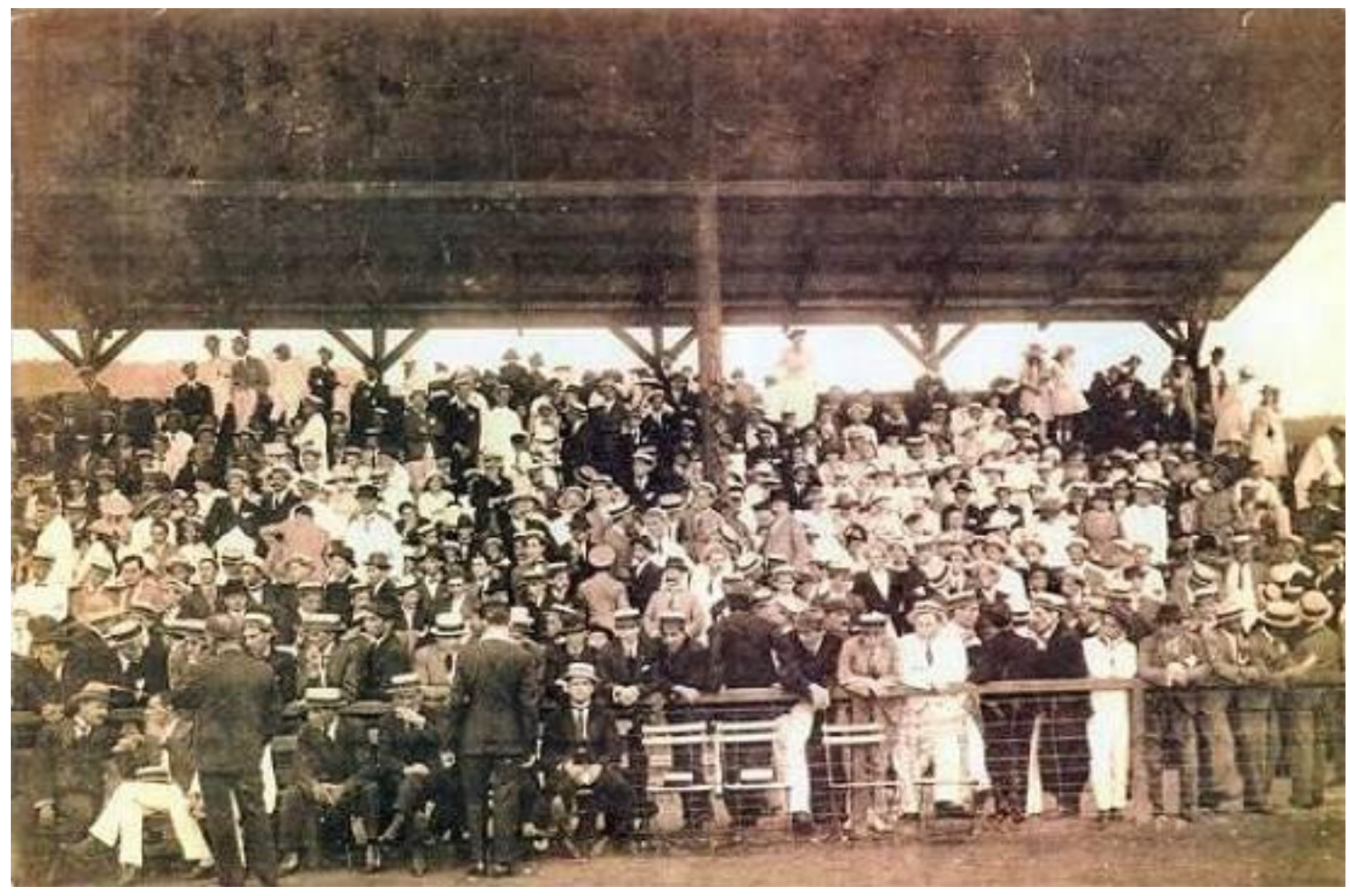

Imagem 24: Estádio do Santos Futebol Clube (atual Vila Belmiro), 1916. Fonte: Centro de Memória do Santos Futebol Clube. 


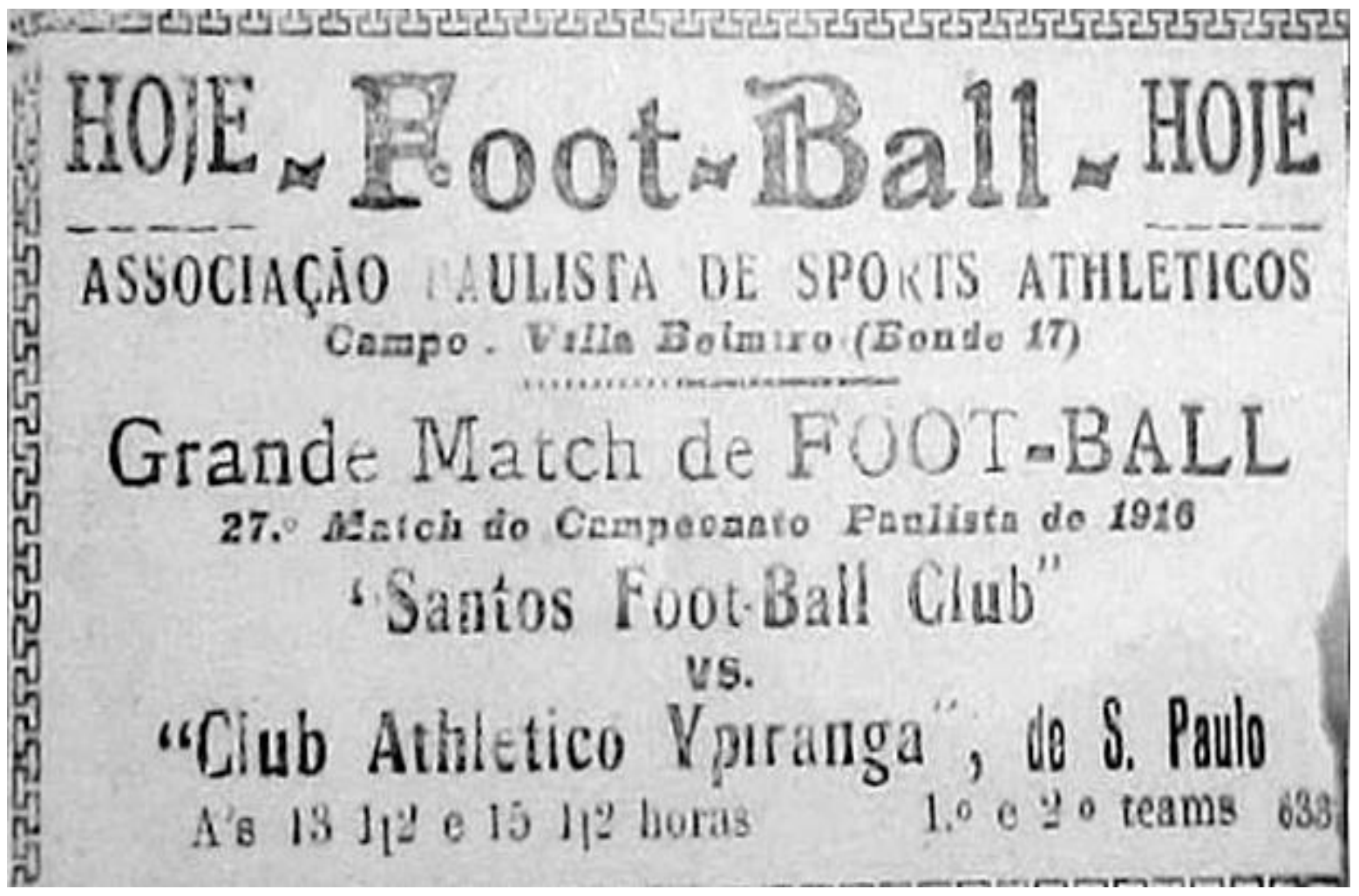

Imagem 25: Jornal A Tribuna, Anúncio da primeira partida oficial no Estádio do Santos Futebol Clube, 1916. Fonte: Centro de Memória do Santos Futebol Clube.

\section{A TRIBUNA}

A AMERCLANA INAUCOIRA, HOJE, A SUA NOVA PRACI DE ES. PORTES, EM VULLA PFLMIRO - O PROGRAMHA DA FESTA --

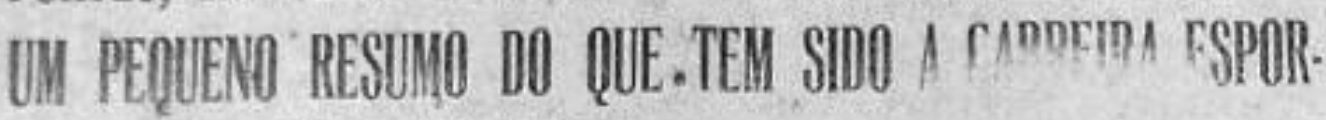
TIVA DO GREMIO "FIDALICO"

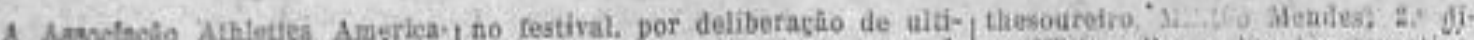

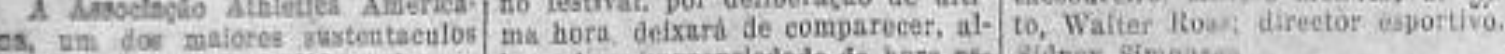

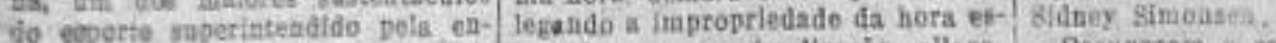

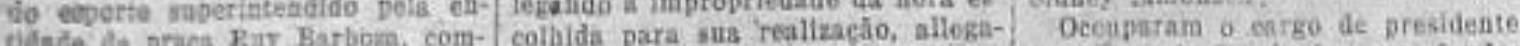

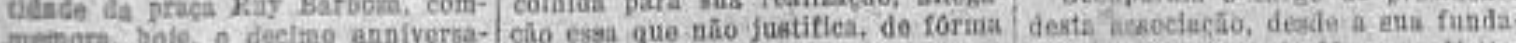

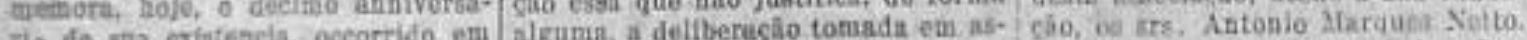

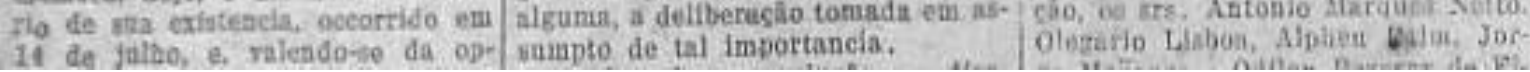

Imagem 26: Jornal A Tribuna, Inauguração da Praça de Esportes da Associação Atlética Americana, 15 de Março de 1925. Fonte: Acervo A Tribuna. 


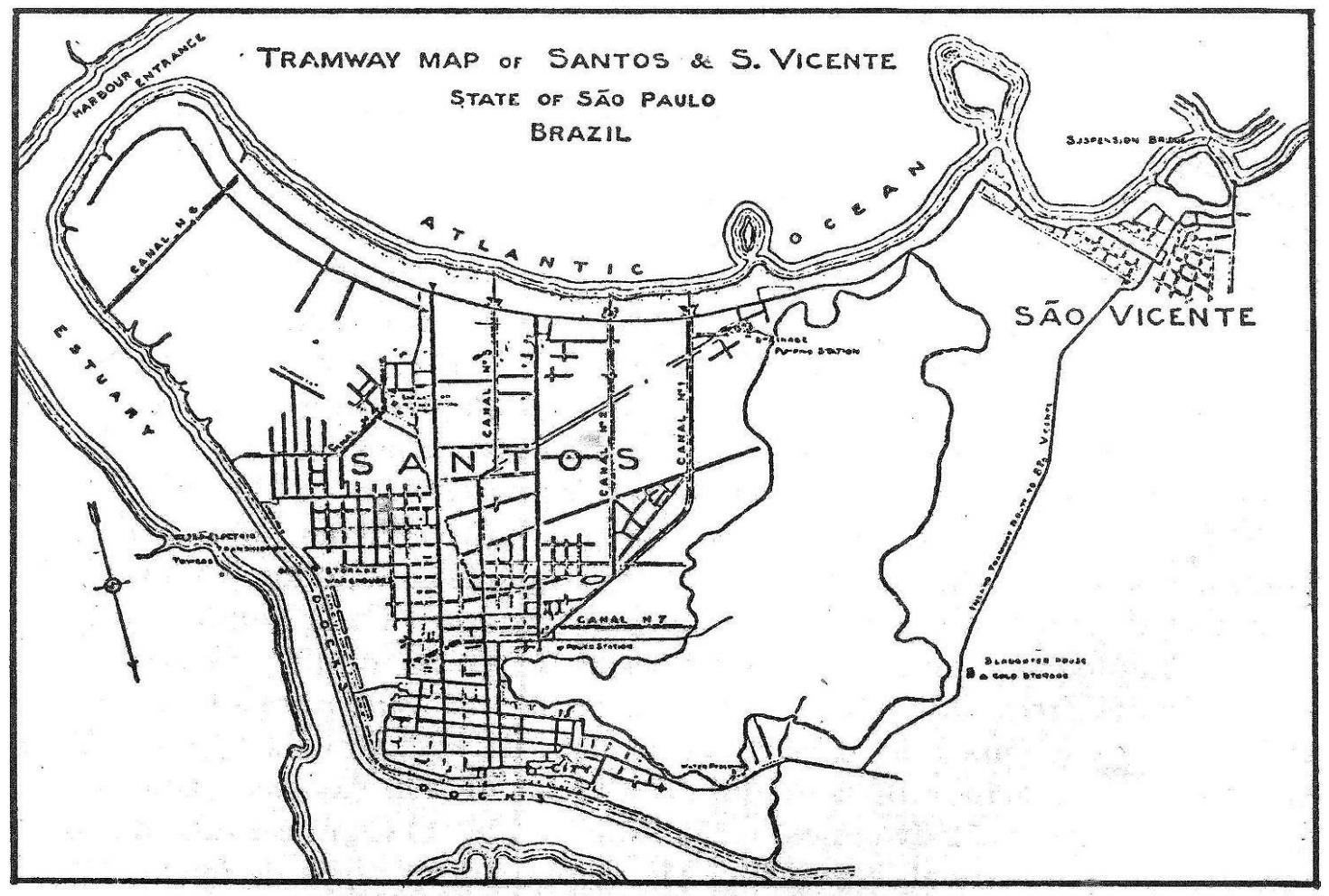

MATP DAS LIXHAS DF TRAMWAY DE SANTOS IE. B\%:TE.

Imagem 27: Mapa Linhas de Bonde de Santos e São Vicente, 1920. Fonte: Fundação Arquivo e Memória de Santos.

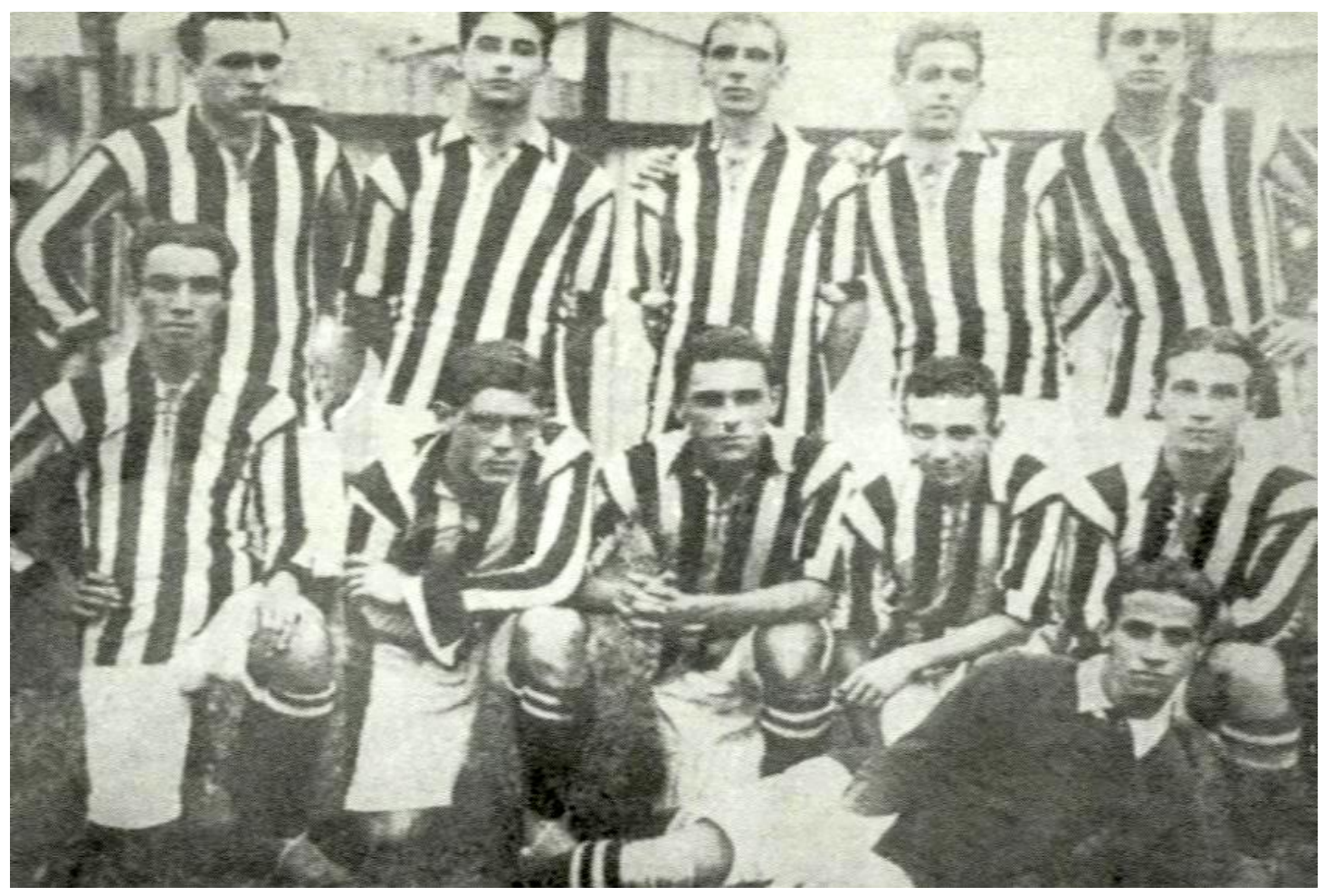

Imagem 28: Primeiro Quadro do Santos Futebol Clube, 1919. Fonte: Centro de Memória do Santos Futebol Clube. 


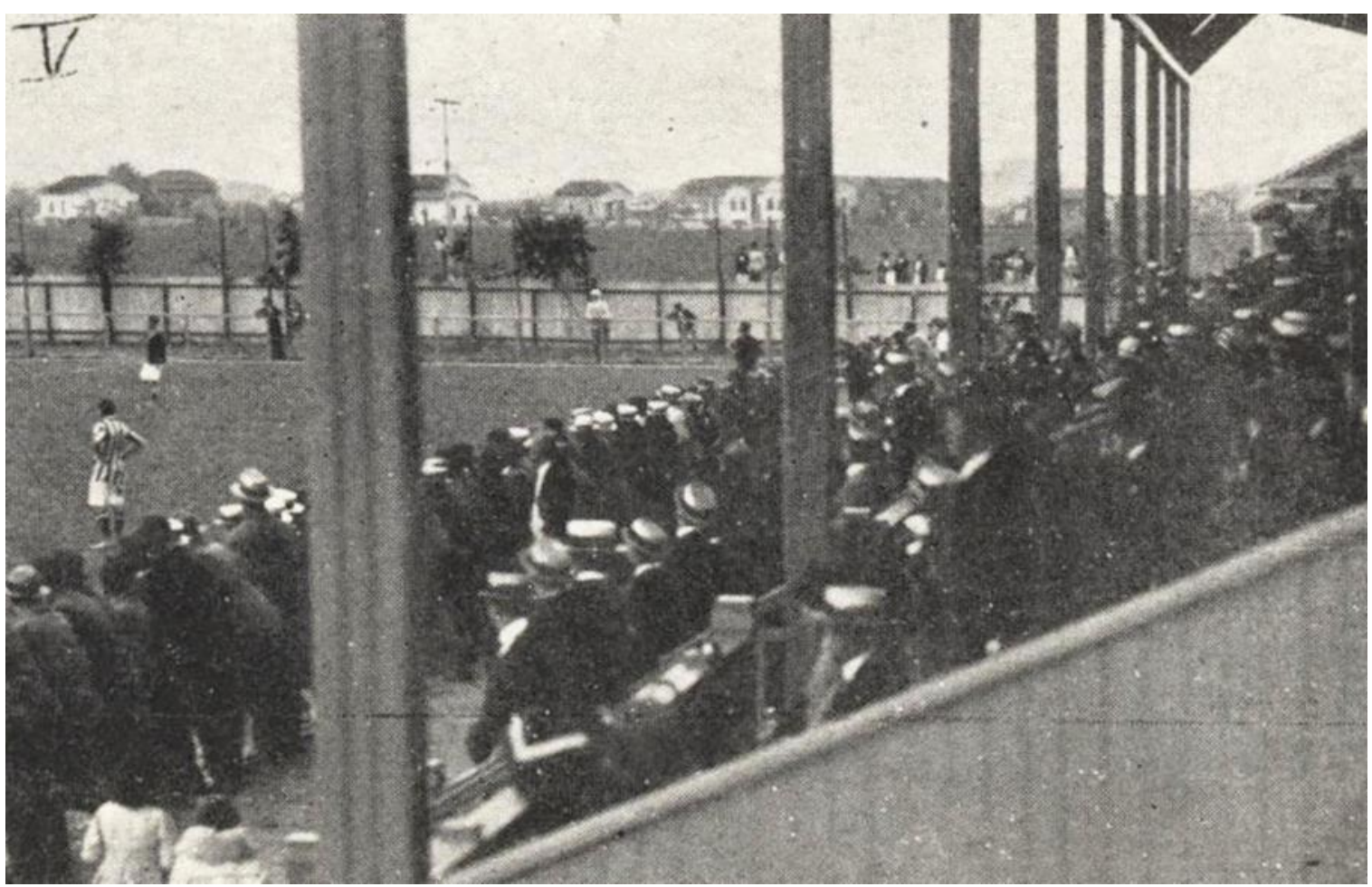

Imagem 29: Santos Futebol Clube em partida contra o Mackenzie no Estádio de Vila Belmiro, 1919. Fonte: Centro de Memória do Santos Futebol Clube.

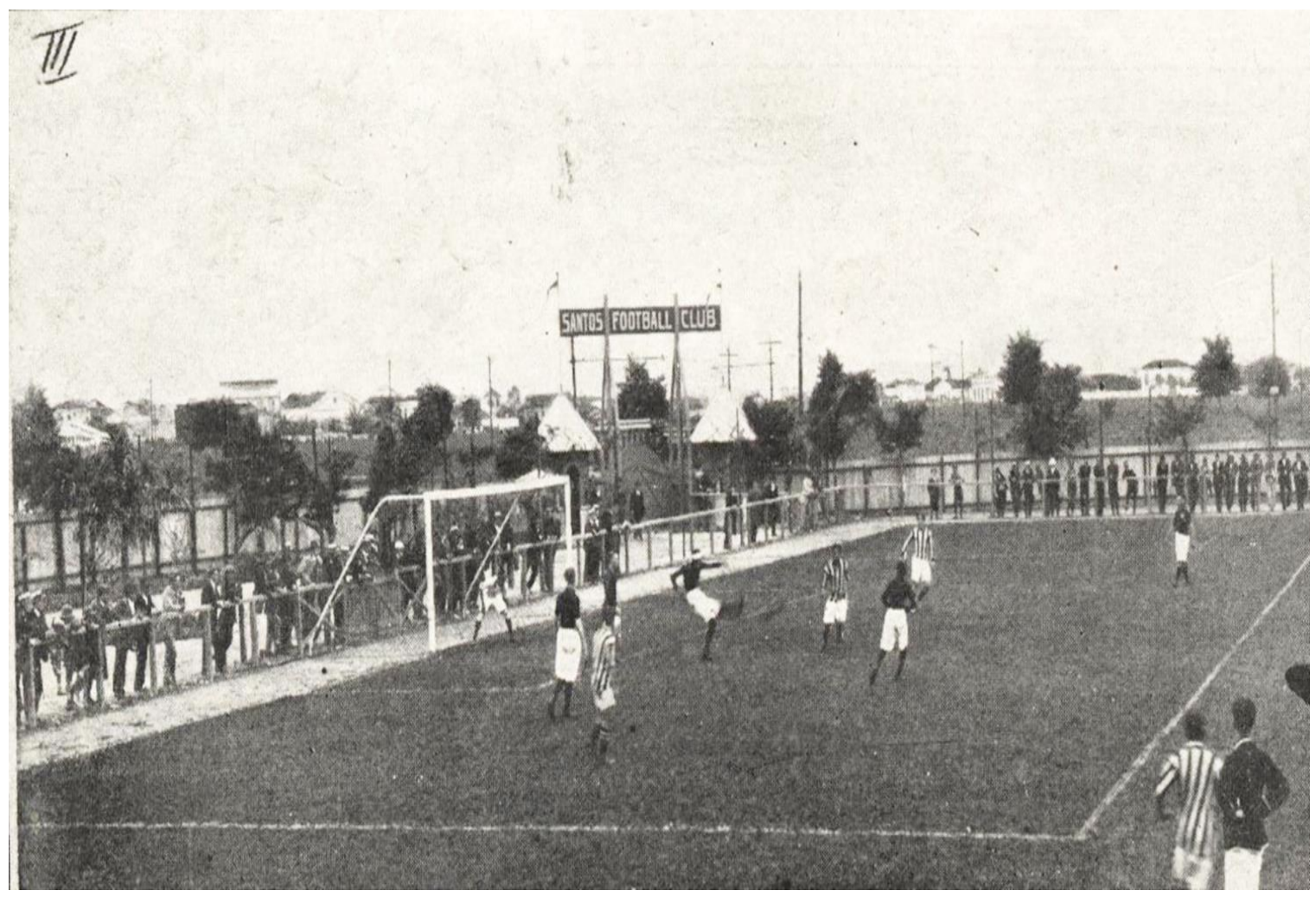

Imagem 30: Santos Futebol Clube em partida contra o Mackenzie no Estádio de Vila Belmiro, 1919. Fonte: Centro de Memória do Santos Futebol Clube. 


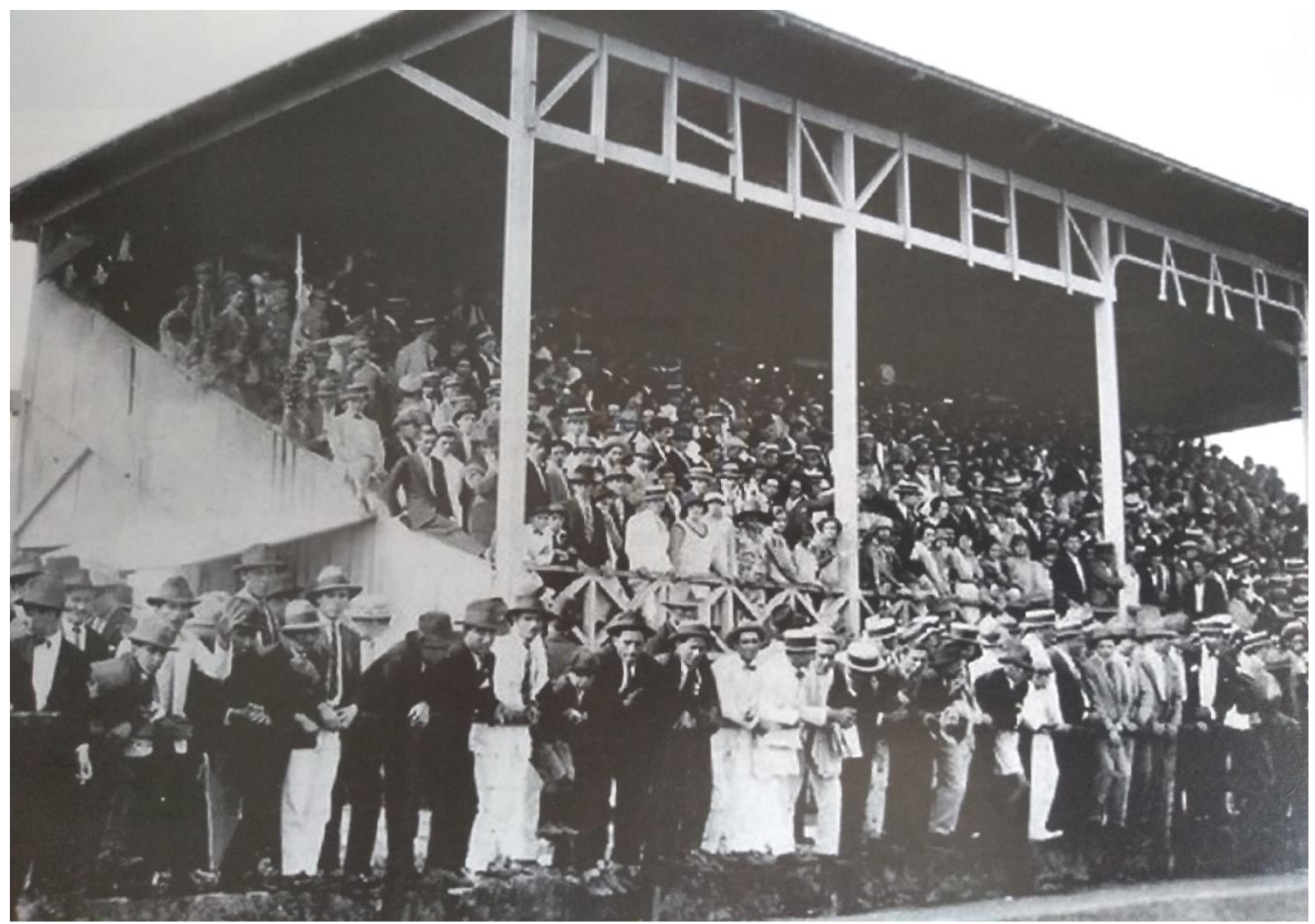

Imagem 31: Estádio Ulrico Mursa, Década de 1920. Fonte: Acervo Associação Atlética Portuguesa. 


\section{Considerações Finais}

O futebol pode explicar os caminhos de uma sociedade, as suas contradições, os seus acordos, os seus amálgamas. Finalizo essa breve pesquisa com a clareza de que nenhum espaço urbano no passado recente pode ser lido sem um mínimo de referências ao futebol.

Trabalhamos, durante o desenvolvimento dessa tese, com o pressuposto básico de que a inserção dos esportes na dinâmica espacial das cidades guarda importantes conexões com o advento da modernidade urbana.

A ideia de modernidade - com sua fé inabalável no progresso - impulsionou nas cidades novos valores comportamentais, dos quais destacamos aqui a cultura física e a prática de esportes. Entendemos a atmosfera dita moderna como portadora não apenas de um conjunto de novas expectativas e práticas sociais, mas também de transformações decisivas na espacialidade, que substituíram velhas urbanidades por novas formas de se relacionar com a cidade. As grandes reformas urbanas na Europa do século XIX abriram amplos espaços públicos e preencheram-nos com monumentos que expressavam o triunfo da burguesia e dotaram-nos de eventos e cerimoniais atléticos de apologia ao ideário que associava certa concepção de vida saudável à prática esportiva. Nesse contexto de profundas transformações, pretendemos analisar o paradigmático caso da cidade de Santos.

Importante centro da economia cafeeira paulista e brasileira, a cidade portuária passaria pela transição do século XIX para o século XX em intenso processo de transformação. Os projetos, planos e intervenções de caráter sanitarista modificariam drasticamente a paisagem urbana santista. Palco de algumas das maiores greves e mobilizações operárias da Primeira República, a cidade densamente povoada teria rapidamente um dos mais prolíficos cenários esportivos de seu tempo.

Notoriamente, o futebol aporta no país - e em Santos não seria diferente - enquanto novidade inglesa "civilizadora" e cultuada pelas elites locais ávidas por novos elementos que reforçassem a distinção social. Paulatinamente, os segmentos populares foram se apropriando desta prática esportiva e elaborando novos códigos culturais, bem como instaurando na cidade toda uma nova espacialidade. 
Não podemos deixar de frisar o caráter elitista que todo esse movimento assumiu inicialmente: a imposição de uma nova atitude corporal, através de esportes importados, se inseriu plenamente no projeto civilizador da classe dominante, refletindo o caráter excludente da pretensa modernização idealizada.

À saneada cidade que se constituía, o seu avesso: uma população empobrecida, segregada socialmente - e espacialmente - e, em larga medida, excluída dos benefícios do progresso que se anunciava.

Os conflitos inerentes ao acelerado processo de urbanização encontrariam no futebol um de seus elementos constitutivos. À expansão urbana capitaneada pelo grande capital privado, o surgimento de agremiações de origem e representação variada arrastava pequenas multidões.

O amplo cenário futebolístico que se forma na cidade durante os anos 1910 logo faria da cidade litorânea um dos mais importantes centros do esporte que rapidamente se tornaria uma paixão nacional.

Para finalizar, é urgente enfatizar que a investigação, na busca de uma articulação entre história urbana, história do trabalho e história do esporte, em momento algum teve a pretensão de esgotar os temas abordados. Em uma conjuntura em que o conhecimento histórico, academicamente constituído, vem sendo constantemente vilipendiado e atacado, o presente trabalho tem por objetivo oferecer a sua contribuição, por menor que seja, para o hoje já consolidado campo das pesquisas sobre futebol no Brasil. 


\section{Referências}

ALONSO, Leandro da Silva. Além dos rebocadores: a população santista no limiar do século XX. 2012. Dissertação (mestrado) - PUC/SP, São Paulo.

ÁlVARO, Guilherme. A Campanha Sanitária de Santos: suas causas e seus efeitos. São Paulo: Serviço Sanitário do Estado de São Paulo/Casa Duprat, 1919.

ANDRADE, C.R.M. de. A peste e o plano: o urbanismo sanitarista do engenheiro Saturnino de Brito. 1992. Dissertação (mestrado) - FAU USP, São Paulo.

O plano de Saturnino de Brito para Santos e a construção da cidade moderna no Brasil. Espaço e Debates. São Paulo, n. 34, pp. 55-63, 1993.

ANDRADE, W.T. O discurso do Progresso: a evolução urbana de Santos (1888 - 1930). 1989. Tese (doutorado) - FFLCH USP, São Paulo.

- Santos: urbanismo na época do café (1889 -1930). In: Pereira, Maria Apparecida Franco Pereira (org.). Café, Santos \& Historia. Santos: Leopoldianum, 1995. p.89 106.

ANTUNES, Fátima Martin. Futebol de fábrica em São Paulo. 1992. Dissertação (mestrado), FFLCH USP, São Paulo.

BATALHA, Claudio. Formação da classe operária e projetos de identidade coletiva. In: FERREIRA, Jorge; DELGADO, Lucilia de Almeida Neves. O Brasil Republicano: o tempo do liberalismo excludente (da Proclamação da República à Revolução de 1930). 4. ed. Rio de Janeiro: Civilização Brasileira, 2010.

BAUER, Arnold. Goods, Power and History: Latin America Material Culture. Cambridge. Cambridge University Press, 2001. 
BERMAN, Marshall. Tudo que é sólido desmancha no ar. São Paulo: Companhia das Letras, 1986.

BERNARDINI, Sidney. Os planos da cidade: as políticas de intervenção urbana em Santos. 2003. Dissertação (mestrado) - FAU USP, São Paulo.

BONDUKI, Nabil. Origens da habitação social no Brasil: Arquitetura Moderna, Lei do Inquilinato e Difusão da Casa Própria. São Paulo, Estação Liberdade, 1998.

BONFÁ, Rogério Luis Giampietro. As expulsões de estrangeiros e a defesa da soberania nacional durante a Primeira República Brasileira. História Social. São Paulo, n. 16, 2009.

BRESCIANI, Maria Stella. Da cidade e do urbano: experiências, sensibilidades, projetos. São Paulo: Alameda Casa Editorial, 2018.

BRITO, Francisco Saturnino Rodrigues de. "Projetos e Relatórios. O Saneamento de Santos". In: Obras Completas de Saturnino de Brito, Vol. VII. Rio de Janeiro, Imprensa Nacional, 1943.

CAETANO, Coraly Gará. Desvendando mistérios: Roberto Simonsen e a luta de classes. 1994. Tese (doutorado) - IFCH/UNICAMP, Campinas/SP.

CAMPOS, Cristina de. Cidade e higiene: Geraldo Horácio de Paula Souza e a institucionalização da saúde pública como disciplina acadêmica. 2001. Dissertação (mestrado) - FAU USP, São Paulo.

CÁNOVAS, Marília Dalva Klaumann. Santos e Imigração na Belle Époque. São Paulo, Edusp, Fapesp, 2017.

CARRIÇO, José Marques. O plano de saneamento de Saturnino de Brito para Santos. Revista de Pesquisa em Arquitetura e Urbanismo. São Paulo, n. 22, pp. 30-46, 2015.

CERASOLI, Josianne Francia. Modernização no plural: obras públicas, tensões sociais e a cidadania em São Paulo na passagem do século XIX para o século XX. 2004. Tese (doutorado) IFCH/UNICAMP, Campinas/SP.

COSTA, L.A.M. O ideário urbano paulista na virada do século: o engenheiro Theodoro Sampaio e as questões territoriais e urbanas modernas (1886-1903). 2000. Dissertação (mestrado) FAU USP, São Paulo. 
DARNTON, Robert. O beijo de Lamourette: mídia, cultura e revolução. São Paulo: Companhia das Letras, 1998.

DEBORD, Guy. A Sociedade do Espetáculo. São Paulo: Boitempo, 2010.

DECCA, Maria Auxiliadora Guzzo. A vida fora das fábricas: cotidiano operário em São Paulo (1920-1934). Rio de Janeiro: Paz e Terra, 1987.

DEL PRIORE, Mary; MELO, Victor Andrade de (org). História do Esporte no Brasil. São Paulo: Editora UNESP, 2009

ELIAS, Norbert. O processo civilizador. Rio de Janeiro: Zahar, 1990.

FARIA, Teresa de Jesus Peixoto. Os projetos e obras do engenheiro Saturnino de Brito e a mudança na paisagem urbana. Geografia Ensino \& Pesquisa. São Paulo, v. 19, pp. 115-122, 2015.

FAUSTO, Boris. Trabalho Urbano e Conflito Social, 1880 - 1920. São Paulo: Difel, 1977.

FRANCO JÚNIOR, Hilário. A dança dos deuses: Futebol, sociedade e cultura. São Paulo: Companhia das Letras, 2007.

FRUTUOSO, Maria Suzel Gil. A emigração portuguesa e a sua influência no Brasil: o caso de Santos. 1989. Dissertação (Mestrado) - FFLCH USP, São Paulo.

. O Café e a Imigração em Santos. In: Pereira, Maria Apparecida Franco (org.). Café, Santos \& História. Santos Leopoldianum, 1995.

GAMBETA, Wilson. Desacumular a pobreza: Santos, limiar do século. Espaço e Debates. São Paulo, 1984.

Soldados da saúde: a formação dos serviços de saúde pública em São Paulo. 1988. Dissertação (mestrado) - FFLCH USP, São Paulo.

A bola rolou: o Velódromo paulista e os espetáculos de futebol (1895 1916). 2013. Tese (Doutorado) - FFLCH USP, São Paulo.

GITAHY, M.L.C. Ventos do Mar. São Paulo, Editora UNESP, 1992.

. "Os trabalhadores da construção civil na belle époque, 1889-1914" in Anais do Il Congresso Brasileiro de História Econômica, vol.II, 1997: 118-132. 
GIULIANOTTI, Richard. Sociologia do futebol: dimensões históricas e socioculturais do esporte das multidões. São Paulo: Nova Alexandria, 2010.

GOMES, Angela Maria de Castro. A invenção do trabalhismo. 3. Ed. Rio de Janeiro: FGV, 2005.

GONÇALVES, Alcindo. Lutas e sonhos: cultura política e hegemonia progressista em Santos. São Paulo: Editora UNESP, 1995.

HARDMAN, Francisco Foot e LEONARDI, Victor. História da Indústria e do Trabalho no Brasil: das origens aos anos 1920. São Paulo: Global, 1982.

HOBSBAWM, Eric J.. Mundos do Trabalho. Rio de Janeiro: Paz e Terra, 1987.

. Era dos Impérios (1870 - 1914). Rio de Janeiro: Paz e Terra, 2007.

HONORATO, Cezar. O polvo e o porto: a Companhia Docas de Santos (1888 - 1914). São Paulo: Prisma, 1997.

LANNA, A. L. D. Uma cidade na transição: Santos (1870 - 1913). São Paulo: Hucitec, 1996.

LUCA, Tânia de. O sonho do futuro assegurado: o mutualismo em São Paulo. São Paulo: Contexto, 1990.

MALAIA, João Manuel. Torcer, torcedores, torcedoras, torcida (bras.): 1910-1950. In: HOLLANDA, Bernardo Buarque de. (et al.) A Torcida Brasileira. 1ed. Rio de Janeiro: 7 Letras, 2012 , v. , p. $53-85$.

MARAN, Sheldon. Anarquistas, imigrantes e o movimento operário brasileiro (1890 - 1920). Rio de Janeiro: Paz e Terra, 1979.

MARCONDES, Carina F. P. Casas importadoras de Santos e seus agentes: comércio e cultura material (1870 - 1900). 2010. Dissertação (Mestrado) - FFLCH USP, São Paulo.

MARQUES JR. Arnaldo. Campo, parque, jardim - transformações no espaço público urbano: a Praça Visconde de Mauá em Santos. 2006. Dissertação (Mestrado) - FFLCH USP, São Paulo. 
MASCARENHAS, Gilmar. "Mundo e lugar: a introdução do futebol no Brasil urbano". Experimental. São Paulo (Laboratório de Geografia Política e Planejamento Territorial), mar. 1999, n.6, pp. 95-110. . Várzeas, operários e futebol: uma outra geografia. GEOgraphia (UFF),

p. 32-47. 2002

Entradas e bandeiras: a conquista do Brasil pelo futebol. Rio de Janeiro:

Editora UERJ, 2014.

MATOS, Maria Izilda Santos de. Santos, o porto do café: cidade, cotidiano e trabalho. Estudos Ibero-Americanos, Porto Alegre, v. 30, p. 9-27, 2005.

MAZEVIERO, Maria Carolina. Memória e identidade urbana em Santos: usos e preservação de tipologias arquitetônicas da Avenida Conselheiro Nébias. 2008. Dissertação (Mestrado) - FAU USP, São Paulo.

MELO, Victor Andrade de. Cidade Sportiva: primórdios do esporte no Rio de Janeiro. 1. ed. Rio de Janeiro: Relume Dumará, 2001.

MELO, Victor Andrade de; DRUMOND, Maurício; FORTES, Rafael; SANTOS, João Manuel Casquinha Malaia. Pesquisa histórica e história do esporte. Rio de Janeiro: 7 Letras, 2013.

MELOSI, Martin. "On the cusp of the new public health. Bacteriology, environmental sanitation and the quest for permanence, 1880-1920" In: The sanitary city. Baltimore/London: The Johns Hopkins University Press, 2000.

MORAES, José Geraldo Vinci de. Cidade e cultura urbana na Primeira República. São Paulo: Atual, 1994.

PERROT, Michelle. "Os operários, a moradia e a cidade no século XIX." in Os Excluídos da História. Rio de Janeiro, Paz e Terra, 1988, p.101-125

PIERIN, Gabriel Davi. Santos Football-Club: o nascimento de um gigante. Santos/SP: Realejo Livros, 2011. 
PINHEIRO, Paulo César e HALL, Michael. A Classe Operária no Brasil (1889 - 1930). São Paulo: Brasiliense, 1981.

PRADO JR. Caio. Evolução política do Brasil e outros estudos. São Paulo: Brasiliense, 1971.

PRATA, Ranulfo. Navios Iluminados. 5ạ ed. São Paulo: Edusp, 2015.

ROLNIK, Raquel. A cidade e a lei: legislação, política urbana e territórios na cidade de São Paulo. São Paulo: Studio Nobel/FAPESP, 1997.

SAES, Flávio. A grande empresa de serviços públicos na economia cafeeira. 1979. Tese (doutorado) FEA - USP, São Paulo.

SALES, Pedro Manuel Rivaben. A relação entre o porto e a cidade e sua (re)valorização no território macrometropolitano de São Paulo. 1999. Tese (Doutorado) - FAU USP, São Paulo.

SANTOS, Francisco Martins dos. História de Santos: 1532-1936. 2 vols. São Paulo: Empreza Graphica da Revista dos Tribunaes, 1937.

SANTOS, Milton. A urbanização desigual: a especificidade do fenômeno urbano em países subdesenvolvidos. Petrópolis: Vozes, 1980.

SARTI, Ingrid. Porto Vermelho: os estivadores santistas no sindicato e na política. Rio de Janeiro: Paz e Terra, 1981.

SCHORSKE, Carl. Viena Fin-De-Siècle. São Paulo: Companhia das Letras, 1988.

SEVCENKO, Nicolau. A Revolta da Vacina: mentes insanas em corpos rebeldes. São Paulo: Cosac Naify, 2010.

SILVA, Ivani Ribeiro da. Santos insalubre, café, porto e exploração: palco ideal para a luta dos anarquistas. In: Pereira, Maria Apparecida Franco Pereira (org.). Café, Santos \& Historia. Santos: Leopoldianum, 1995. p.62-88.

SILVA. F. T. Operários sem patrões: os trabalhadores da cidade de Santos no entreguerras. Campinas, SP: Editora da UNICAMP, 2003.

SILVA, F. T. da e GITAHY, M.L.C. "O movimento operário da construção civil santista durante a Primeira Guerra Mundial” In: História Social. Campinas, IFCH/UNICAMP, 1996. 
. "Trabalho e Cultura na Cidade Portuária de Santos (1890 - 1920).

In: El Taller de Historia. Cartagena (Colômbia), Universidad de Cartagena de Indias, 2012.

SILVEIRA, Álvaro dos Santos, ROGÉRIO, Paulo. 100 Anos Sou Mais Briosa. Santos/SP: Realejo Livros, 2017.

SILVEIRA, Sérgio dos Santos. Jabuca dos nossos corações. Santos/SP: Editora Parma, 2002.

SIMAS, Luiz Antonio. O corpo encantado das ruas. Rio de Janeiro: Civilização Brasileira, 2019.

SINGER, Paul. Desenvolvimento econômico e evolução urbana. São Paulo: Edusp, 1968.

VIEIRA, Marina Tucunduva Bittencourt Porto. "Esporte, cidade e modernidade: Santos". In Melo, Victor Andrade de. Os sports e as cidades brasileiras: transição dos séculos XIX e XX. Rio de Janeiro: Apicuri, 2010.

THOMPSON, E.P. A miséria da teoria. Rio de Janeiro: Zahar, 1981.

A formação da classe operária inglesa. Rio de Janeiro: Paz e Terra, 3 vols, 2011.

TOLEDO, Edilene Teresinha. O sindicalismo revolucionário em São Paulo e na Itália: circulação de idéias e experiências na militância sindical transnacional entre 1890 e o fascismo. 2002. Tese (doutorado) - IFCH/UNICAMP, Campinas/SP. 


\section{Lista de imagens}

\section{Capítulo 1}

- Imagem 1: Casa de Câmara e Cadeia, Década de 1880. Fonte: Fundação de Arquivo e Memória de Santos.

- Imagem 2: Bondes no Largo do Rosário, Década de 1880. Fonte: Fundação de Arquivo e Memória de Santos.

- Imagem 3: Rua Santo Antônio (futura Rua do Comércio), Década de 1880. Fonte: Fundação de Arquivo e Memória de Santos.

- Imagem 4: Rua XV de Novembro, Década de 1890. Fonte: Fundação de Arquivo e Memória de Santos.

- Imagem 5: Bairro de Vila Mathias, 1900. Fonte: Fundação de Arquivo e Memória de Santos.

- Imagem 6: Avenida Ana Costa. Década de 1900. Fonte: Fundação de Arquivo e Memória de Santos.

- Imagem 7: Desinfectório. 1902. Fonte: Arquivo Público do Estado de São Paulo

- Imagem 8: Hospital de Isolamento. 1902. Fonte: Arquivo Público do Estado de São Paulo

- Imagem 9: Comissão Sanitária. 1899. Fonte: Arquivo Público do Estado de São Paulo

- Imagem 10: Constituição Municipal de 1894. Fonte: Câmara Municipal de Santos

- Imagem 11: Trecho de Canal de Saneamento. 1907. Fonte: Fundação de Arquivo e Memória de Santos.

- Imagem 12: Passadiço do Canal 1. 1907. Fonte: Fundação de Arquivo e Memória de Santos.

- Imagem 13: Inauguração de Canal de Saneamento. 1907. Fonte: Obras Completas de Saturnino de Brito

- Imagem 14: Inauguração de Canal de Saneamento. 1907. Fonte: Obras Completas de Saturnino de Brito

- Imagem 15: Inauguração de Canal de Saneamento. 1907. Fonte: Arquivo Público do Estado de São Paulo 
- Imagem 16: Inauguração de Canal de Saneamento. 1907. Fonte: Fundação Arquivo e Memória de Santos

- Imagem 17: Planta de Santos. 1878. Fonte: Arquivo Público do Estado de São Paulo

- Imagem 18: Planta de Santos. 1895. Fonte: Arquivo Público do Estado de São Paulo

- Imagem 19: Planta de Santos. 1896. Fonte: Câmara Municipal de Santos

- Imagem 20: Planta de Santos. 1903. Fonte: Arquivo Público do Estado de São Paulo

- Imagem 21: Planta de Santos. 1905. Fonte: Arquivo Público do Estado de São Paulo

- Imagem 22: Planta dos Canais de Drenagem. 1907. Fonte: Arquivo Público do Estado de São Paulo

- Imagem 23: Planta de Santos. 1910. Fonte: Arquivo Público do Estado de São Paulo

- Imagem 24: Planta dos Distritos de Santos. 1913. Fonte: Arquivo Público do Estado de São Paulo

- Imagem 25: Planta da Rede de Esgotos de Santos. 1913. Fonte: Arquivo Público do Estado de São Paulo

- Imagem 26: Planta de Santos. 1916. Fonte: Arquivo Público do Estado de São Paulo

- Imagem 27: Planta de Santos. 1920. Fonte: Arquivo Público do Estado de São Paulo

\section{Capítulo 2}

- Imagem 1: Carregadores de Café, Década de 1900. Fonte: Fundação Arquivo e Memória de Santos.

- Imagem 2: Carroceiros no Porto de Santos. 1908. Fonte: Fundação Arquivo e Memória de Santos.

- Imagem 3: Diário de Santos, 26 de Outubro de 1897. Fonte: Sociedade Humanitária dos Empregados do Comércio.

- Imagem 4: O Estado de São Paulo, 20 de Junho de 1905. Fonte: Sociedade Humanitária dos Empregados do Comércio.

- Imagem 5: Trabalhadores do Saneamento, 1906. Fonte: Fundação Arquivo e Memória de Santos.

- Imagem 6: Trabalhadores do Saneamento, 1906. Fonte: Fundação Arquivo e Memória de Santos. 
- Imagem 7: Porto de Santos, 1901. Fonte: Instituto Moreira Salles.

- Imagem 8: Porto de Santos, 1901. Fonte: Instituto Moreira Salles.

- Imagem 9: Porto de Santos, 1902. Fonte: Instituto Moreira Salles.

- Imagem 10: Porto de Santos, Lançamento de Pedra Fundamental de Novo Trecho de Cais, 1901. Fonte: Fundação Arquivo e Memória de Santos.

- Imagem 11: Trabalhadores da Pedreira do Jabaquara, 1909. Fonte: Fundação Arquivo e Memória de Santos.

- Imagem 12: Funcionários da Companhia Docas na Pedreira do Jabaquara, 1913. Fonte: Instituto Moreira Salles.

- Imagem 13: Companhia Docas de Santos, 1899. Fonte: Fundação Arquivo e Memória de Santos.

- Imagem 14: Escritório Geral da Companhia Docas, sem data. Fonte: Fundação Arquivo e Memória de Santos.

- Imagem 15: A Tribuna, 26 de Janeiro de 1939, Edição Comemorativa. Fonte: A Tribuna

- Imagem 16: Diário de Santos, Anúncio da Companhia Construtora de Santos, 1913. Fonte: Sociedade Humanitária dos Empregados do Comércio.

- Imagem 17: Roberto Cochrane Simonsen, sem data. Fonte: Acervo Digital USP.

- Imagem 18: Jornal União dos Operários, 15 de Setembro de 1905. Fonte: Arquivo Público do Estado de São Paulo.

- Imagem 19: Jornal A Vanguarda, 04 de Janeiro de 1909. Fonte: Arquivo Público do Estado de São Paulo.

- Imagem 20: Jornal A Tribuna Operária, 01 de Maio de 1909. Fonte: Arquivo Público do Estado de São Paulo.

- Imagem 21: Jornal Aurora Social, 14 de Julho de 1910. Fonte: Arquivo Público do Estado de São Paulo.

- Imagem 22: Jornal O Proletário, 01 de Janeiro, de 1912. Fonte: Arquivo Público do Estado de São Paulo.

- Imagem 23: Chalés de Madeira no Bairro do Saboó, 1920. Fonte: Fundação Arquivo e Memória de Santos.

- Imagem 24: Chalés de Madeira no Bairro do Saboó, 1920. Fonte: Fundação Arquivo e Memória de Santos (Detalhamento da imagem anterior)

- Imagem 25: Festa de Operários, 1909. Fonte: Fundação Arquivo e Memória de Santos. 


\section{Capítulo 3}

- Imagem 1: Avenida Ana Costa, 1907. Fonte: Fundação Arquivo e Memória de Santos

- Imagem 2: Avenida Conselheiro Nébias, 1898. Fonte: Fundação Arquivo e Memória de Santos

- Imagem 3: Cartão Postal, Avenida Conselheiro Nébias, 1913. Fonte: Fundação Arquivo e Memória de Santos

- Imagem 4: Sede do Clube XV, Avenida Conselheiro Nébias, 1902. Fonte: Fundação Arquivo e Memória de Santos.

- Imagem 5: Partida de Cricket, Clube dos Ingleses, 1897. Fonte: Acervo Santos Athletic Club

- Imagem 6: Sportiva Annual, Prova de Salto, Clube dos Ingleses, 1905. Fonte: Acervo Santos Athletic Club

- Imagem 7: Sede Social do Clube dos Ingleses, 1908. Fonte: Acervo Santos Athletic Club

- Imagem 8: Sócios do Clube dos Ingleses, 1912. Fonte: Acervo Santos Athletic Club

- Imagem 9: Membros do Velo Clube, Década de 1900. Fonte: Fundação Arquivo e Memória de Santos

- Imagem 10: Clube Internacional de Regatas, 1904. Fonte: Fundação Arquivo e Memória de Santos

- Imagem 11: Clube Internacional de Regatas, 1904. Fonte: Fundação Arquivo e Memória de Santos

- Imagem 12: Integrantes da primeira partida oficial de futebol disputada em Santos, Praia do Embaré, 1902. Fonte: Museu De Vaney

- Imagem 13: Campo de Futebol da Avenida Ana Costa, 1907. Fonte: Museu De Vaney

- Imagem 14: Time de Futebol do Internacional, 1905. Fonte: Museu De Vaney

- Imagem 15: Santos Futebol Clube contra Santos Athletic Club, Campo da Avenida Ana Costa, 1912. Fonte: Centro de Memória Santos Futebol Clube

- Imagem 16: Equipe do Santos Futebol Clube, 1917. Fonte: Centro de Memória Santos Futebol Clube

- Imagem 17: Pedreira do Jabaquara, Década de 1910. Fonte: Acervo Codesp 
- Imagem 18: Bairro do Jabaquara (confluência dos canais 1 e 2 onde seria construído o Estádio Ulrico Mursa), Década de 1910. Fonte: Fundação Arquivo e Memória de Santos

- Imagem 19: Equipe da Associação Atlética Portuguesa, 1917. Fonte: Acervo da Associação Atlética Portuguesa.

- Imagem 20: Planta do Bairro da Vila Belmiro (com as especificações dos locais dos estádios de Santos Futebol Clube e Associação Atlética Americana), sem data. Fonte: Fundação Arquivo e Memória de Santos.

- Imagem 21: Construção da Praça de Esportes do Santos Futebol Clube, sem data. Fonte: Centro de Memória do Santos Futebol Clube.

- Imagem 22: Construção da Praça de Esportes do Santos Futebol Clube, sem data. Fonte: Centro de Memória do Santos Futebol Clube.

- Imagem 23: Estádio do Santos Futebol Clube (atual Vila Belmiro), 1916. Fonte: Centro de Memória do Santos Futebol Clube.

- Imagem 24: Estádio do Santos Futebol Clube (atual Vila Belmiro), 1916. Fonte: Centro de Memória do Santos Futebol Clube.

- Imagem 25: Jornal A Tribuna, Anúncio da primeira partida oficial no Estádio do Santos Futebol Clube, 1916. Fonte: Centro de Memória do Santos Futebol Clube.

- Imagem 26: Jornal A Tribuna, Inauguração da Praça de Esportes da Associação Atlética Americana, 15 de Março de 1925. Fonte: Acervo A Tribuna.

- Imagem 27: Mapa Linhas de Bonde de Santos e São Vicente, 1920. Fonte: Fundação Arquivo e Memória de Santos.

- Imagem 28: Primeiro Quadro do Santos Futebol Clube, 1919. Fonte: Centro de Memória do Santos Futebol Clube.

- Imagem 29: Santos Futebol Clube em partida contra o Mackenzie no Estádio de Vila Belmiro, 1919. Fonte: Centro de Memória do Santos Futebol Clube.

- Imagem 30: Santos Futebol Clube em partida contra o Mackenzie no Estádio de Vila Belmiro, 1919. Fonte: Centro de Memória do Santos Futebol Clube.

- Imagem 31: Estádio Ulrico Mursa, Década de 1920. Fonte: Acervo Associação Atlética Portuguesa. 


\section{Fontes Impressas}

\section{Fontes do Arquivo Histórico do Estado de São Paulo}

- COMPANHIA DOCAS DE SANTOS, Regulamento. Santos, 1894.

- SANTOS (Município). Câmara Municipal e Intendência. Atas, Leis, Regulamentos e Código de Posturas. 1892 a 1903.

- SANTOS (Município). Câmara Municipal e Intendência. Relatório apresentado à Câmara Municipal da Cidade de Santos (Estado de São Paulo) em sessão de 3 de agosto de 1893 pelo Intendente de Higiene Dr. Isidoro José Ribeiro Campos. Santos: Typ. a Vapor do Diário de Santos, 1893.

- SANTOS (Município). Câmara Municipal e Intendência. Relatório apresentado à Câmara Municipal da Cidade de Santos (Estado de São Paulo) em sessão de 7 de janeiro de 1897 por Antonio Iguatemy Martins - Presidente da Câmara Municipal. Santos: Typ. a Vapor do Diário de Santos, 1897.

- SANTOS (Município). Câmara Municipal e Intendência. Relatório apresentado à Câmara Municipal da Cidade de Santos (Estado de São Paulo) pelo seu Presidente Antonio Iguatemy Martins e pelo Intendente Antonio José Malheiros Junior em 7 de janeiro de 1898. Santos: Typ. a Vapor do Diário de Santos, 1898.

- SANTOS (Município). Câmara Municipal e Intendência. Relatório apresentado à Câmara Municipal da Cidade de Santos (Estado de São Paulo) pelo seu presidente José Carneiro Bastos e pelo Intendente Adolpho Vaz Guimarães em 7 de janeiro de 1900. Santos: Typ. da Cidade de Santos, 1900.

- SANTOS (Município). Câmara Municipal e Intendência. Relatório apresentado à Câmara Municipal da Cidade de Santos (Estado de São Paulo) pelo seu presidente José Carneiro Bastos e pelo Intendente Adolpho Vaz Guimarães em 7 de janeiro de 1901. Santos: Typ. da Cidade de Santos, 1901.

- SANTOS (Município). Câmara Municipal e Intendência. Relatório apresentado à Câmara Municipal da Cidade de Santos (Estado de São Paulo) pelo seu presidente Francisco Corrêa de Almeida Moraes e pelo Intendente Francisco Malta Cardoso em 7 de janeiro de 1903. Santos: Typ. da Cidade de Santos, 1903. 
- SANTOS (Município). Câmara Municipal e Intendência. Relatório apresentado à Câmara Municipal da Cidade de Santos (Estado de São Paulo) pelo seu presidente Francisco Corrêa de Almeida Moraes e pelo Intendente Manoel Galeão Carvalhal em 7 de janeiro de 1905. Santos: Typ. da Tribuna de Santos, 1905.

- SÃo PAUlo (Estado). Decreto 233, de 2 de março de 1894 - Código Sanitário. In: Coleção das Leis e Decretos e do Estado de São Paulo de 1894. São Paulo: Typ. do Diário Oficial, 1918.

- SÃo PAUlo (Estado). Secretaria de Agricultura, Comércio e Obras Públicas. Ofícios. 1891.

- SÃo PAUlo (Estado). Secretaria de Agricultura, Comércio e Obras Públicas. Ofícios. 1893.

- SÃO PAUlo (Estado). Secretaria de Agricultura, Comércio e Obras Públicas. Ofícios. 1895.

- SÃO PAUlo (Estado). Secretaria de Agricultura, Comércio e Obras Públicas. Ofícios. 1898.

- SÃO PAULO (Estado). Secretaria do Interior. Serviço Sanitário. 1892 - 1897.

- SÃO PAUlO (Estado). Secretarias de Interior e Justiça. Relatório apresentado ao Sr. Presidente do Estado de São Paulo Dr. Cesário Motta Junior, Secretário dos Negócios do Interior em 31 de março de 1895. São Paulo: Typ. do Diário Oficial, 1895.

- SÃo PAUlo (Estado). Secretaria dos Negócios do Interior. Comissão de Serviço Sanitário. Relatório Annual. Santos, 1894.

- SÃO PAUlo (Estado). Secretaria dos Negócios do Interior. Comissão de Serviço Sanitário. Relatório dos Inspetores Sanitários ao Chefe da Comissão. Santos, 18951896.

- SÃO PAULO (Estado). Relatório apresentado ao Dr. Jorge Tibiriçá, Secretário dos Negócios da Agricultura, Comércio e Obras Públicas em 4 de abril de 1893. São Paulo: Typ. do Diário Oficial, 1893.

- SÃo PAUlo (Estado). Relatório da Secretaria dos Negócios da Agricultura, Comércio e Obras Públicas do Estado de São Paulo apresentado em 3 de março de 1895 ao Dr. Bernardino de Campos (Presidente do Estado) pelo Dr. Jorge Tibiriçá, Secretário de Estado. São Paulo: Typ. Paulista a Vapor, 1895.

- SÃo PAUlo (Estado). Relatório da Secretaria dos Negócios da Agricultura, Comércio e Obras Públicas do Estado de São Paulo apresentado em 5 de março de 1897 ao Dr. 
Manoel Ferraz de Campos Salles (Presidente do Estado) pelo Dr. Álvaro Augusto da Costa Carvalho, Secretário de Estado. São Paulo: Typ. a Vapor Espíndola e Siqueira Co., 1897.

\section{Fontes do Arquivo da Fundação Arquivo e Memória de Santos}

- SANTOS (Município). Código de Posturas Municipais de Santos, 1897

- SANTOS (Município). Fundo da Câmara e Intendência. Atas. 1890-1892.

- SANTOS (Município). Fundo da Câmara e Intendência. Atas. 1893 - 1895.

- SANTOS (Município). Fundo da Câmara e Intendência. Atas. 1896-1898.

- SANTOS (Município). Fundo da Câmara e Intendência. Atas. 1899 - 1901.

- SANTOS (Município). Fundo da Câmara e Intendência. Atas. 1908-1910.

- SANTOS (Município). Recenseamento da cidade e do município de Santos de 31 de dezembro de 1913. Santos, 1914.

\section{Fontes do Museu do Porto (CODESP)}

- Correspondências ativas e passivas da diretoria da Companhia Docas de Santos (19131935)

4. Imprensa

- Acervo A Tribuna: A Tribuna (Santos), 1898-1903, 1904-1908, 1909-1912

- Hemeroteca Municipal de Santos: A Tribuna (Santos), 1913-1920.

- Sociedade Humanitária dos Empregados do Comércio de Santos: O Diário de Santos (Santos), 1901-1916, Aurora Social (Santos), 1909-1910, A Vanguarda (Santos), 1909, União dos Operários (Santos), 1904-1905. 
- Arquivo Edgard Leuenroth: O Proletário (1911-1912), A Voz do Trabalhador (1914), A Plebe (1917), Tribuna Operária (1909), O Dois de Fevereiro (1914)

- Museu De Vaney: A Tribuna (Santos), 1939.

\section{Fontes de agremiações esportivas}

- Arquivos do Santos Athletic Club: Livro de Atas: 1889-1899.

- Arquivos do Santos Athletic Club: Livro de Atas: 1900-1905.

- Arquivos do Santos Futebol Clube: Livro de Atas Reunião da Diretoria: 1913-1916.

- Arquivos do Santos Futebol Clube: Livro de Atas Reunião da Diretoria: 1916-1919.

- Associação Atlética Portuguesa. Atas: 1917-1920.

- Brasil Futebol Clube. Ata de Fundação: 1913

- Jabaquara Atlético Clube. Ata de Fundação: 1914. 